\title{
Sesquiterpenes from an Eastern African Medicinal Mushroom Belonging to the Genus Sanghuangporus
}

Tian Cheng, ${ }^{\dagger}$ Clara Chepkirui, ${ }^{\dagger}$ Cony Decock, ${ }^{\dagger}$ Josphat Clement Matasyoh, ${ }^{\S}$ Marc Stadler ${ }^{*},{ }^{\dagger}$

$\dagger$ Department of Microbial Drugs, Helmholtz Centre for Infection Research (HZI); German Centre for Infection Research (DZIF), Partner Site Hannover/Braunschweig, Inhoffenstrasse 7, 38124 Braunschweig, Germany

$\$$ Mycothéque de l' Universite Catholique de Louvain (BCCM/MUCL), Place Croix du Sud 3, B-1348 Louvain-la-Neuve, Belgium

$\S$ Department of Chemistry, Faculty of Sciences, Egerton University, P.O. Box 536, 20115, Njoro, Kenya 


\section{Contents}

1 and 2D NMR data for $(6 R, 7 S, 10 R)$-7,10-epoxy-7,11-dimethyldodec-1-ene-6,11-diol (1).... 8

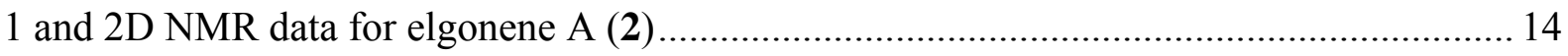

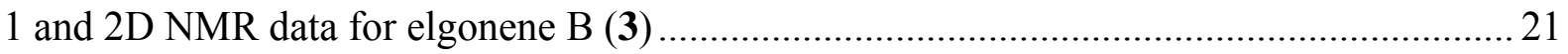

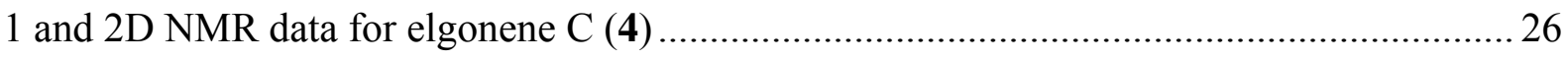

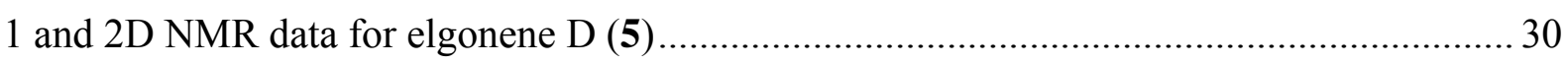

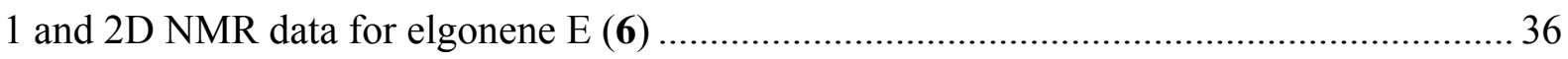

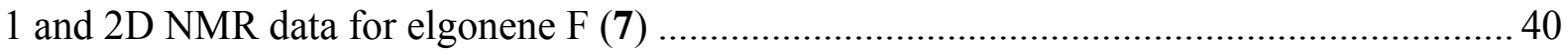

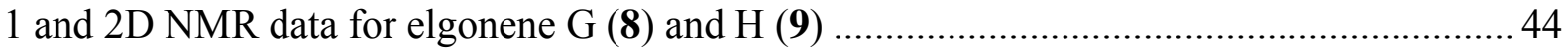

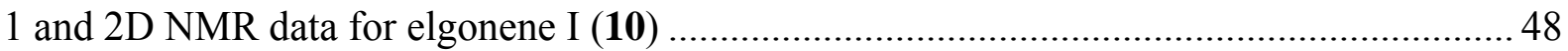

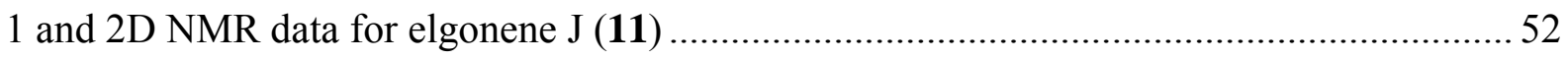

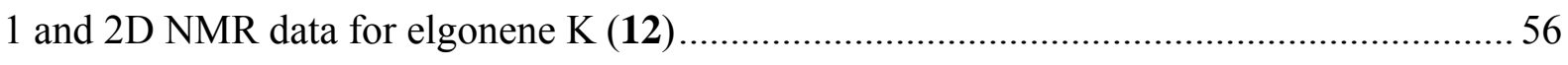

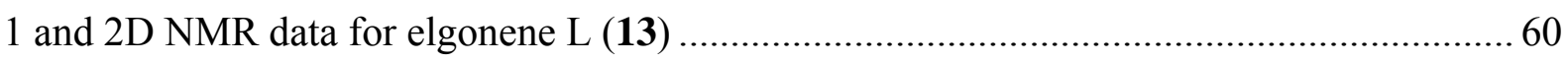

NMR data of $(6 R, 7 S, 10 R)$-7,10-epoxy-7,11-dimethyldodec-1-ene-6,11-diol (1), (S)- MTPA ester

NMR data of $(6 R, 7 S, 10 R)$-7,10-epoxy-7,11-dimethyldodec-1-ene-6,11-diol (1), (S)- MTPA ester 64

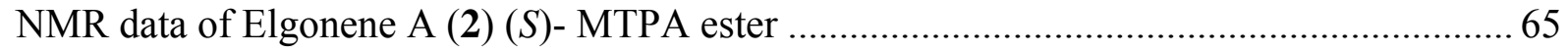

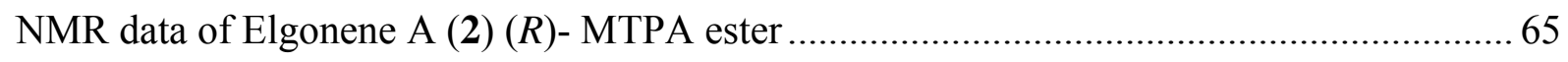

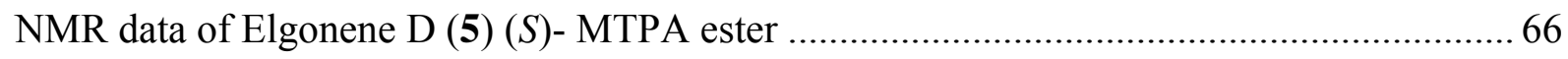

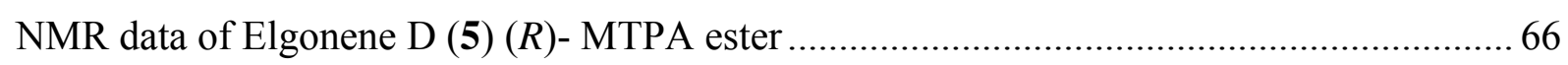

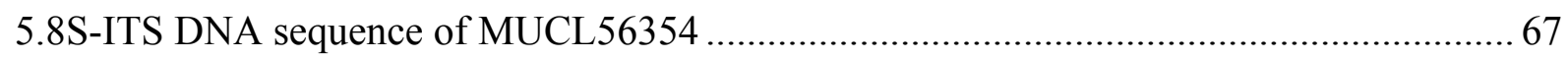

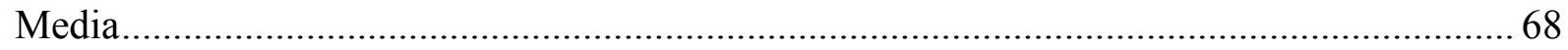




\section{LIST OF FIGURES}

Figure 1: ${ }^{1} \mathrm{H}$ NMR spectrum of $(6 R, 7 S, 10 R)-7,10$-epoxy-7,11-dimethyldodec-1-ene-6,11-diol (1) in acetone- $\mathrm{d}_{6}(700 \mathrm{MHz})$

Figure 2: ${ }^{13} \mathrm{C}$ NMR spectrum of $(6 R, 7 S, 10 R)-7,10$-epoxy-7,11-dimethyldodec-1-ene-6,11-diol (1) in acetone- $\mathrm{d}_{6}(175 \mathrm{MHz})$

Figure 3: DEPT spectrum of $(6 R, 7 S, 10 R)-7,10$-epoxy-7,11-dimethyldodec-1-ene-6,11-diol (1) in acetone- $\mathrm{d}_{6}(175 \mathrm{MHz})$

Figure 4: ${ }^{1} \mathrm{H},{ }^{13} \mathrm{C}$ HSQC spectrum of $(6 R, 7 S, 10 R)$-7,10-epoxy-7,11-dimethyldodec-1-ene-

6,11-diol (1) in acetone-d 6 (700 MHz, $175 \mathrm{MHz})$.

Figure 5: ${ }^{1} \mathrm{H},{ }^{13} \mathrm{C}$ HMBC spectrum of $(6 R, 7 S, 10 R)-7,10$-epoxy-7,11-dimethyldodec-1-ene-

6,11-diol (1) in acetone- $\mathrm{d}_{6}(700 \mathrm{MHz}, 175 \mathrm{MHz})$....

Figure 6: ${ }^{1} \mathrm{H},{ }^{1} \mathrm{H}$ COSY NMR spectrum of $(6 R, 7 S, 10 R)-7,10$-epoxy-7,11-dimethyldodec-1-

ene-6,11-diol (1) in acetone-d 6 (700MHz).

Figure 7: 1H, 1H ROESY NMR spectrum of (6R,7S,10R)-7,10-epoxy-7,11-dimethyldodec-1ene-6,11-diol (1) in acetone-d6 (700MHz)

Figure 8: HR-ESIMS spectrum for $(6 R, 7 S, 10 R)$-7,10-epoxy-7,11-dimethyldodec-1-ene-6,11diol (1) .

Figure 9: ${ }^{1} \mathrm{H}$ NMR spectrum of $(6 R, 7 S, 10 R)$-7,10-epoxy-7,11-dimethyldodec-1-ene-6,11-diol

(1) S-MTPA ester in pyridine-d $\mathrm{d}_{5}(700 \mathrm{MHz})$

Figure 10: ${ }^{1} \mathrm{H}{ }^{1} \mathrm{H}$ COSY NMR spectrum of $(6 R, 7 S, 10 R)$-7,10-epoxy-7,11-dimethyldodec-1ene-6,11-diol (1) S-MTPA ester in pyridine-d $\mathrm{d}_{5}(700 \mathrm{MHz})$.

Figure 11: ${ }^{1} \mathrm{H}$ NMR spectrum of $(6 R, 7 S, 10 R)-7,10$-epoxy-7,11-dimethyldodec-1-ene-6,11-diol

(1) $R$-MTPA ester in pyridine- $\mathrm{d}_{5}(700 \mathrm{MHz})$. 13

Figure 12: ${ }^{1} \mathrm{H}{ }^{1} \mathrm{H}$ COSY NMR spectrum of $(6 \mathrm{R}, 7 S, 10 R)-7,10$-epoxy-7,11-dimethyldodec-1-

ene-6,11-diol (1) R-MTPA ester in pyridine-d $\mathrm{d}_{5}(700 \mathrm{MHz})$ 14

Figure 13: ${ }^{1} \mathrm{H}$ NMR spectrum of elgonene $\mathrm{A}(2)$ in $\mathrm{CDCl}_{3}(500 \mathrm{MHz})$................................. 14

Figure 14: ${ }^{13} \mathrm{C}$ NMR spectrum of elgonene $\mathrm{A}(2)$ in $\mathrm{CDCl}_{3}(125 \mathrm{MHz})$............................... 15

Figure 15: DEPT NMR spectrum of elgonene $\mathrm{A}(2)$ in $\mathrm{CDCl}_{3}(125 \mathrm{MHz})$............................ 15

Figure 16: ${ }^{1} \mathrm{H},{ }^{13} \mathrm{C}$ HSQC NMR spectrum of elgonene A (2) in $\mathrm{CDCl}_{3}(500 \mathrm{MHz}, 125 \mathrm{MHz})$

Figure 17: ${ }^{1} \mathrm{H},{ }^{13} \mathrm{C}$ HMBC NMR spectrum of elgonene $\mathrm{A}(2)$ in $\mathrm{CDCl}_{3}(500 \mathrm{MHz}, 125 \mathrm{MHz})$

Figure 18: ${ }^{1} \mathrm{H},{ }^{1} \mathrm{H}$ COSY NMR spectrum of elgonene A (2) in $\mathrm{CDCl}_{3}(500 \mathrm{MHz})$................ 17

Figure 19: ${ }^{1} \mathrm{H},{ }^{1} \mathrm{H}$ ROESY NMR spectrum of elgonene A (2) in $\mathrm{CDCl}_{3}(500 \mathrm{MHz})$............. 18

Figure 20: HR-ESIMS spectrum of elgonene A (2) ......................................................... 18

Figure 21: ${ }^{1} \mathrm{HNMR}$ spectrum of elgonene A (2) S- MTPA ester in pyridine $\mathrm{d}_{5}(700 \mathrm{MHz}) \ldots 19$

Figure 22: ${ }^{1} \mathrm{H},{ }^{1} \mathrm{H}$ COSY spectrum of elgonene A (2) $S$ - MTPA ester in pyridine $\mathrm{d}_{5}(700 \mathrm{MHz})$

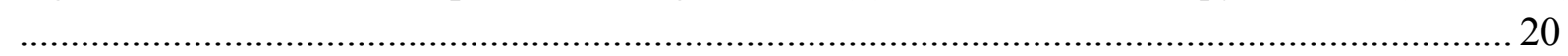

Figure 23: ${ }^{1} \mathrm{HNMR}$ spectrum of elgonene A (2) R- MTPA ester in pyridine $\mathrm{d}_{5}(700 \mathrm{MHz}) \ldots 20$

Figure 24: $1 \mathrm{H}, 1 \mathrm{H}$ COSY spectrum of elgonene A (2) $R$ - MTPA ester in pyridine $\mathrm{d}_{5}(700$

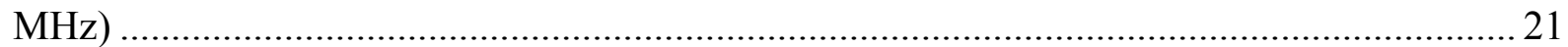

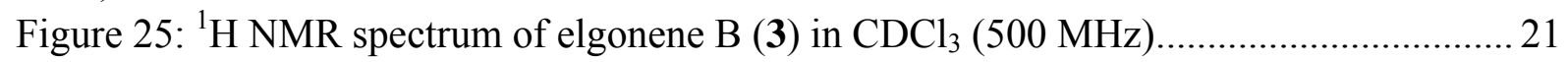

Figure 26: ${ }^{13} \mathrm{C}$ NMR spectrum of elgonene $\mathrm{B}(3)$ in $\mathrm{CDCl}_{3}(125 \mathrm{MHz})$................................. 22

Figure 27: DEPT NMR spectrum of elgonene $\mathrm{B}(3)$ in $\mathrm{CDCl}_{3}(125 \mathrm{MHz})$............................ 22 
Figure 28: ${ }^{1} \mathrm{H},{ }^{13} \mathrm{C}$ HSQC NMR spectrum of elgonene $\mathrm{B}(3)$ in $\mathrm{CDCl}_{3}(500 \mathrm{MHz}, 125 \mathrm{MHz})$

Figure 29: ${ }^{1} \mathrm{H},{ }^{13} \mathrm{C}$ HMBC NMR spectrum of elgonene B (3) in $\mathrm{CDCl}_{3}(500 \mathrm{MHz}, 125 \mathrm{MHz})$

Figure 30: ${ }^{1} \mathrm{H},{ }^{1} \mathrm{H}$ COSY NMR spectrum of elgonene B (3) in $\mathrm{CDCl}_{3}(500 \mathrm{MHz})$................ 24

Figure 31: ${ }^{1} \mathrm{H},{ }^{1} \mathrm{H}$ ROESY NMR spectrum of elgonene $\mathrm{B}(3)$ in $\mathrm{CDCl}_{3}(500 \mathrm{MHz})$............. 25

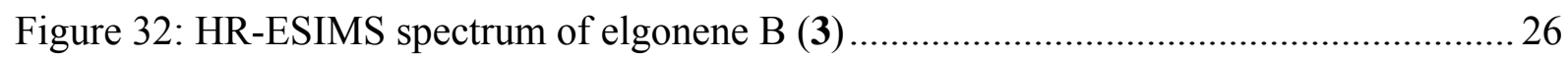

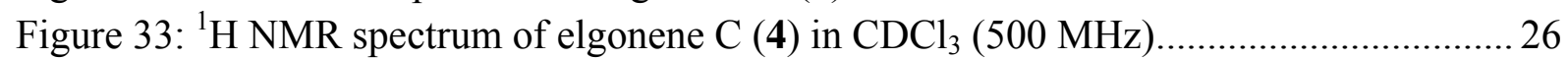

Figure 34: ${ }^{13} \mathrm{C}$ NMR spectrum of elgonene $\mathrm{C}(4)$ in $\mathrm{CDCl}_{3}(125 \mathrm{MHz})$................................ 27

Figure 35: DEPT NMR spectrum of elgonene $\mathrm{C}(4)$ in $\mathrm{CDCl}_{3}(125 \mathrm{MHz})$............................ 27

Figure 36: ${ }^{1} \mathrm{H},{ }^{13} \mathrm{C}$ HSQC NMR spectrum of elgonene $\mathrm{C}(4)$ in $\mathrm{CDCl}_{3}(500 \mathrm{MHz}, 125 \mathrm{MHz})$

Figure 37: ${ }^{1} \mathrm{H},{ }^{13} \mathrm{C}$ HMBC NMR spectrum of elgonene $\mathrm{C}(4)$ in $\mathrm{CDCl}_{3}(500 \mathrm{MHz}, 125 \mathrm{MHz})$

Figure 38: ${ }^{1} \mathrm{H},{ }^{1} \mathrm{H}$ COSY NMR spectrum of elgonene $\mathrm{C}(4)$ in $\mathrm{CDCl}_{3}(500 \mathrm{MHz}) \ldots \ldots \ldots \ldots \ldots . . . . .29$

Figure 39: ${ }^{1} \mathrm{H},{ }^{1} \mathrm{H}$ ROESY NMR spectrum of elgonene $\mathrm{C}(4)$ in $\mathrm{CDCl}_{3}(500 \mathrm{MHz})$.............. 29

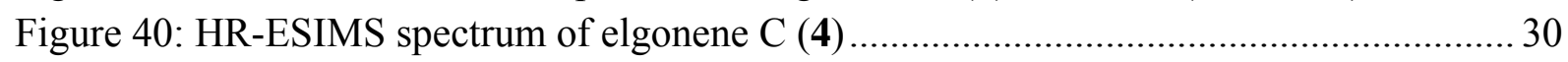

Figure 41: ${ }^{1} \mathrm{H}$ NMR spectrum of elgonene $\mathrm{D}(5)$ in acetone- $\mathrm{d}_{6}(500 \mathrm{MHz})$............................. 30

Figure 42: ${ }^{13} \mathrm{C}$ NMR spectrum of elgonene $\mathrm{D}(5)$ in acetone- $\mathrm{d}_{6}(125 \mathrm{MHz})$.......................... 31

Figure 43: DEPT NMR spectrum of elgonene D (5) in acetone- $\mathrm{d}_{6}(125 \mathrm{MHz})$..................... 31

Figure 44: ${ }^{1} \mathrm{H},{ }^{13} \mathrm{C}$ HSQC NMR spectrum of elgonene D (5) in acetone-d $\mathrm{d}_{6}(500 \mathrm{MHz}, 125$

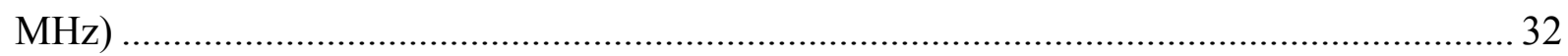

Figure 45: ${ }^{1} \mathrm{H},{ }^{13} \mathrm{C}$ HMBC NMR spectrum of elgonene D (5) in acetone- $\mathrm{d}_{6}(500 \mathrm{MHz}, 125$

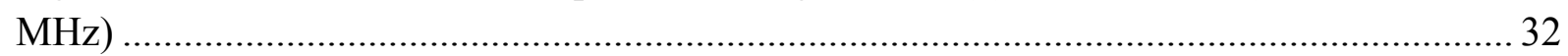

Figure 46: ${ }^{1} \mathrm{H},{ }^{1} \mathrm{H}$ COSY NMR spectrum of elgonene D (5) in acetone-d $\mathrm{d}_{6}(500 \mathrm{MHz})$.......... 33

Figure 47: ${ }^{1} \mathrm{H},{ }^{1} \mathrm{H}$ ROESY NMR spectrum of elgonene D (5) in acetone- $\mathrm{d}_{6}(500 \mathrm{MHz}) \ldots \ldots . .33$

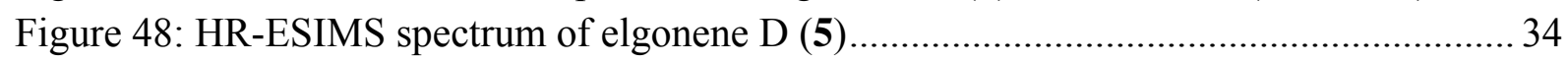

Figure 49: ${ }^{1} \mathrm{HNMR}$ spectrum of elgonene D (5) (R)- MTPA ester in pyridine $\mathrm{d}_{5}(700 \mathrm{MHz}) 34$

Figure 50: ${ }^{1} \mathrm{H},{ }^{1} \mathrm{H}$ COSY NMR spectrum of elgonene D (5) (R)- MTPA ester in pyridine $\mathrm{d}_{5}$

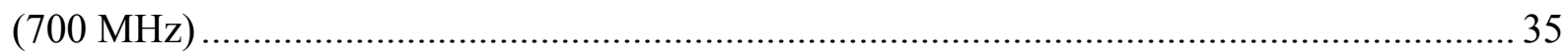

Figure 51: ${ }^{1} \mathrm{HNMR}$ spectrum of elgonene D (5) (S)- MTPA ester in pyridine $\mathrm{d}_{5}(700 \mathrm{MHz}) .35$

Figure 52: ${ }^{1} \mathrm{H},{ }^{1} \mathrm{H}$ COSY NMR spectrum of elgonene D (5) (S)- MTPA ester in pyridine $\mathrm{d}_{5}$

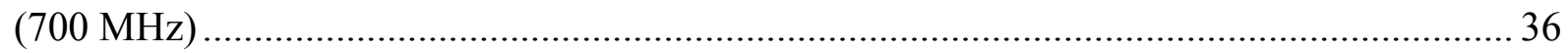

Figure 53: ${ }^{1} \mathrm{HNMR}$ spectrum of elgonene $\mathrm{E}(\mathbf{6})$ in methanol $\mathrm{d}_{4}(700 \mathrm{MHz})$........................... 36

Figure 54: ${ }^{13} \mathrm{C}$ NMR spectrum of elgonene $\mathrm{E}(\mathbf{6})$ in methanol $\mathrm{d}_{4}(175 \mathrm{MHz})$......................... 37

Figure 55: DEPT NMR spectrum of elgonene $\mathrm{E}(6)$ in methanol $\mathrm{d}_{4}(175 \mathrm{MHz})$................... 37

Figure 56: ${ }^{1} \mathrm{H},{ }^{13} \mathrm{C}$ HSQC NMR spectrum of elgonene $\mathrm{E}(6)$ in methanol $\mathrm{d}_{4}(700 \mathrm{MHz}, 125$

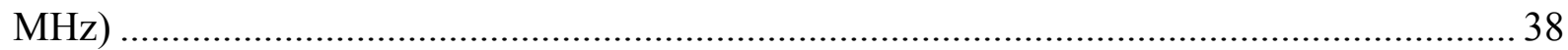

Figure 57: ${ }^{1} \mathrm{H},{ }^{13} \mathrm{C}$ HMBC NMR spectrum of elgonene $\mathrm{E}(6)$ in methanol $\mathrm{d}_{4}(700 \mathrm{MHz}, 125$

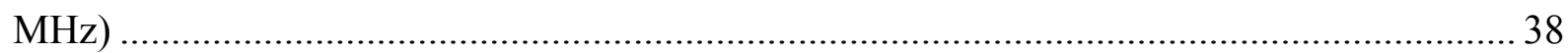

Figure 58: ${ }^{1} \mathrm{H},{ }^{1} \mathrm{H}$ COSY NMR spectrum of elgonene E (6) in methanol $\mathrm{d}_{4}(700 \mathrm{MHz})$........ 39

Figure 59: ${ }^{1} \mathrm{H},{ }^{1} \mathrm{H}$ ROESY NMR spectrum of elgonene $\mathrm{E}(\mathbf{6})$ in methanol $\mathrm{d}_{4}(700 \mathrm{MHz}) \ldots . .39$

Figure 60: HR-ESIMS spectrum of elgonene E (6) ........................................................ 40

Figure 61: ${ }^{1} \mathrm{H}$ NMR spectrum of elgonene $\mathrm{F}(7)$ in $\mathrm{CDCl}_{3}(700 \mathrm{MHz})$................................. 40

Figure 62: ${ }^{13} \mathrm{C}$ NMR spectrum of elgonene $\mathrm{F}(7)$ in $\mathrm{CDCl}_{3}(175 \mathrm{MHz})$............................... 41 
Figure 63: DEPT NMR spectrum of elgonene $\mathrm{F}(7)$ in $\mathrm{CDCl}_{3}(175 \mathrm{MHz})$

Figure 64: ${ }^{1} \mathrm{H},{ }^{13} \mathrm{C}$ HSQC NMR spectrum of elgonene $\mathrm{F}(7)$ in $\mathrm{CDCl}_{3}(700 \mathrm{MHz}, 175 \mathrm{MHz}) 42$ Figure 65: ${ }^{1} \mathrm{H},{ }^{13} \mathrm{C}$ HMBC NMR spectrum of elgonene $\mathrm{F}(7)$ in $\mathrm{CDCl} 3(700 \mathrm{MHz}, 175 \mathrm{MHz})$

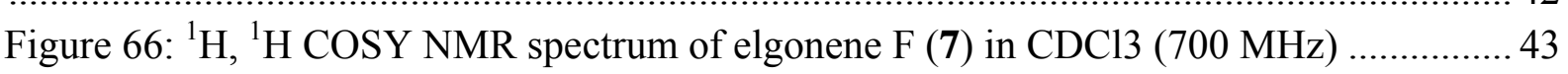

Figure 67: ${ }^{1} \mathrm{H},{ }^{1} \mathrm{H}$ ROESY NMR spectrum of elgonene $\mathrm{F}(7)$ in $\mathrm{CDCl}_{3}(700 \mathrm{MHz}) \ldots \ldots \ldots \ldots . . . . .43$

Figure 68: HR-ESIMS spectrum of elgonene F (7) ........................................................ 44

Figure 69: ${ }^{1} \mathrm{H}$ NMR spectrum of elgonene $\mathrm{G}(\mathbf{8})$ and $\mathrm{H}(\mathbf{9})$ in $\mathrm{CDCl}_{3}(700 \mathrm{MHz})$.................. 44

Figure 70: ${ }^{13} \mathrm{C}$ NMR spectrum of elgonene $\mathrm{G}(\mathbf{8})$ and $\mathrm{H}(\mathbf{9})$ in $\mathrm{CDCl}_{3}(175 \mathrm{MHz})$................. 45

Figure 71: DEPT NMR spectrum of elgonene $\mathrm{G}(\mathbf{8})$ and $\mathrm{H}(\mathbf{9})$ in $\mathrm{CDCl}_{3}(175 \mathrm{MHz}) \ldots \ldots \ldots . . . .45$

Figure 72: ${ }^{1} \mathrm{H},{ }^{13} \mathrm{C}$ HSQC NMR spectrum of elgonene $\mathrm{G}(\mathbf{8})$ and $\mathrm{H}(\mathbf{9})$ in $\mathrm{CDCl}_{3}(700 \mathrm{MHz}$,

$175 \mathrm{MHz})$ 46

Figure 73: ${ }^{1} \mathrm{H},{ }^{13} \mathrm{C}$ HMBC NMR spectrum of elgonene $\mathrm{G}(\mathbf{8})$ and $\mathrm{H}(\mathbf{9})$ in $\mathrm{CDCl}_{3}(700 \mathrm{MHz}$, $175 \mathrm{MHz})$ 46

Figure 74: ${ }^{1} \mathrm{H},{ }^{1} \mathrm{H}$ COSY NMR spectrum of elgonene $\mathrm{G}(\mathbf{8})$ and $\mathrm{H}(\mathbf{9})$ in $\mathrm{CDCl}_{3}(700 \mathrm{MHz}) 47$ Figure 75: ${ }^{1} \mathrm{H},{ }^{1} \mathrm{H}$ ROESY NMR spectrum of elgonene $\mathrm{G}(\mathbf{8})$ and $\mathrm{H}(\mathbf{9})$ in $\mathrm{CDCl}_{3}(700 \mathrm{MHz})$

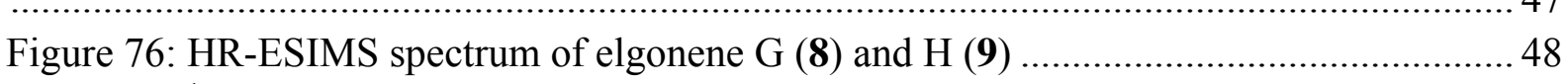

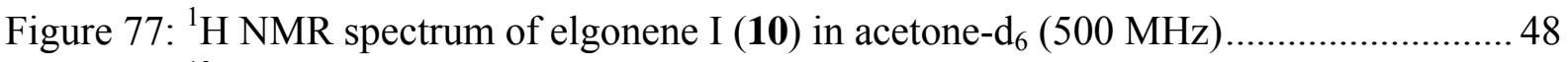

Figure 78: ${ }^{13} \mathrm{C}$ NMR spectrum of elgonene I (10) in acetone- $\mathrm{d}_{6}(125 \mathrm{MHz})$.......................... 49

Figure 79: DEPT NMR spectrum of elgonene I (10) in acetone- $\mathrm{d}_{6}(125 \mathrm{MHz})$...................... 49

Figure 80: ${ }^{1} \mathrm{H},{ }^{13} \mathrm{C}$ HSQC NMR spectrum of elgonene I (10) in acetone-d ${ }_{6}(500 \mathrm{MHz}, 125$

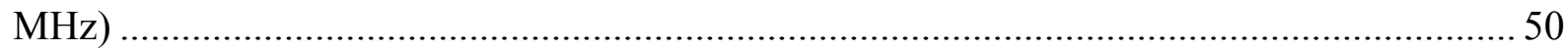

Figure 81: ${ }^{1} \mathrm{H},{ }^{13} \mathrm{C}$ HMBC NMR spectrum of elgonene I (10) in acetone- $\mathrm{d}_{6}(500 \mathrm{MHz}, 125$

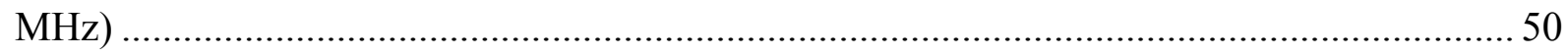

Figure 82: ${ }^{1} \mathrm{H},{ }^{1} \mathrm{H}$ COSY NMR spectrum of elgonene I (10) in acetone-d ${ }_{6}(500 \mathrm{MHz}) \ldots \ldots \ldots . . .51$

Figure $83:{ }^{1} \mathrm{H},{ }^{1} \mathrm{H}$ ROESY NMR spectrum of elgonene $\mathrm{I}(\mathbf{1 0})$ in acetone- $\mathrm{d}_{6}(500 \mathrm{MHz})$........ 51

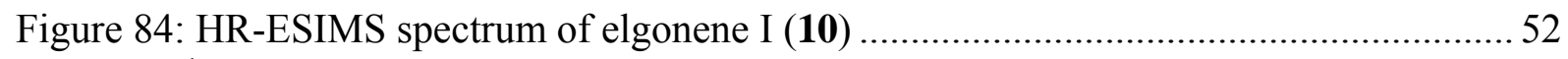

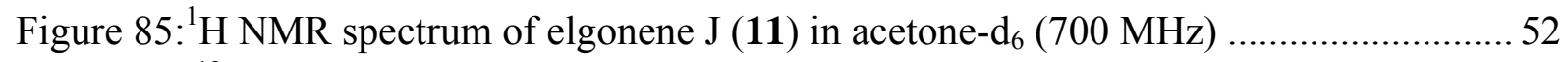

Figure 86: ${ }^{13} \mathrm{C}$ NMR spectrum of elgonene $\mathrm{J}(\mathbf{1 1})$ in acetone- $\mathrm{d}_{6}(175 \mathrm{MHz})$........................... 53

Figure 87: DEPT NMR spectrum of elgonene $\mathrm{J}(\mathbf{1 1})$ in acetone- $\mathrm{d}_{6}(175 \mathrm{MHz})$...................... 53

Figure 88: ${ }^{1} \mathrm{H},{ }^{13} \mathrm{C}$ HSQC NMR spectrum of elgonene $\mathrm{J}(\mathbf{1 1})$ in acetone-d $\mathrm{d}_{6}(700 \mathrm{MHz}, 175$

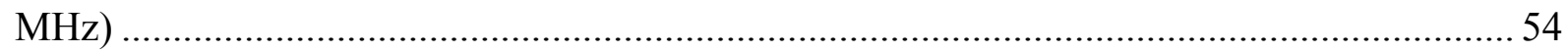

Figure 89: ${ }^{1} \mathrm{H},{ }^{13} \mathrm{C}$ HMBC NMR spectrum of elgonene $\mathrm{J}(\mathbf{1 1})$ in acetone- $\mathrm{d}_{6}(700 \mathrm{MHz}, 175$

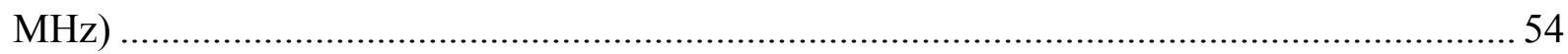

Figure 90: ${ }^{1} \mathrm{H},{ }^{1} \mathrm{H}$ COSY NMR spectrum of elgonene $\mathrm{J}(\mathbf{1 1})$ in acetone- $\mathrm{d}_{6}(700 \mathrm{MHz}) \ldots \ldots \ldots . .55$

Figure 91: ${ }^{1} \mathrm{H},{ }^{1} \mathrm{H}$ ROESY NMR spectrum of elgonene $\mathrm{J}(\mathbf{1 1})$ in acetone- $\mathrm{d}_{6}(700 \mathrm{MHz})$....... 55

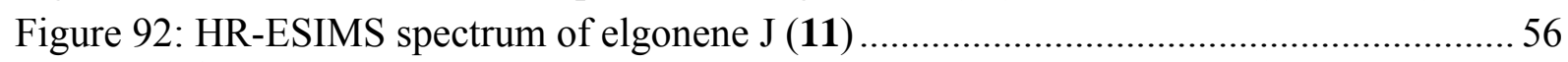

Figure 93: ${ }^{1} \mathrm{H}$ NMR spectrum of elgonene $\mathrm{K}(12)$ in $\mathrm{CDCl}_{3}(500 \mathrm{MHz})$............................... 56

Figure 94: ${ }^{13} \mathrm{C}$ NMR spectrum of elgonene $\mathrm{K}(12)$ in $\mathrm{CDCl}_{3}(125 \mathrm{MHz})$............................... 57

Figure 95: DEPT NMR spectrum of elgonene $\mathrm{K}(12)$ in $\mathrm{CDCl}_{3}(125 \mathrm{MHz})$............................ 57

Figure 96: ${ }^{1} \mathrm{H},{ }^{13} \mathrm{C}$ HSQC NMR spectrum of elgonene $\mathrm{K}(\mathbf{1 2})$ in $\mathrm{CDCl}_{3}(500 \mathrm{MHz}, 125 \mathrm{MHz})$

Figure 97: ${ }^{1} \mathrm{H},{ }^{13} \mathrm{C}$ HMBC NMR spectrum of elgonene $\mathrm{K}(\mathbf{1 2})$ in $\mathrm{CDCl}_{3}(500 \mathrm{MHz}, 125 \mathrm{MHz})$ 
Figure 98: ${ }^{1} \mathrm{H},{ }^{1} \mathrm{H}$ COSY NMR spectrum of elgonene $\mathrm{K}$ (12) in $\mathrm{CDCl}_{3}(500 \mathrm{MHz})$.............. 59

Figure 99: ${ }^{1} \mathrm{H},{ }^{1} \mathrm{H}$ ROESY NMR spectrum of elgonene $\mathrm{K}(12)$ in $\mathrm{CDCl}_{3}(500 \mathrm{MHz}) \ldots \ldots \ldots . . .59$

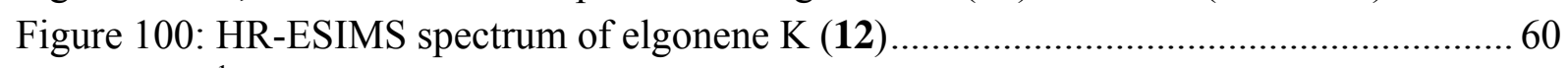

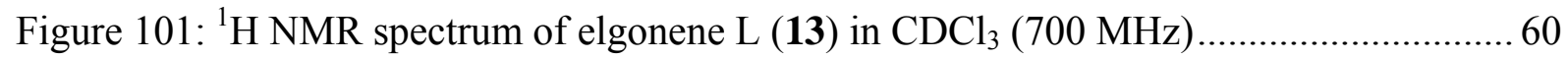

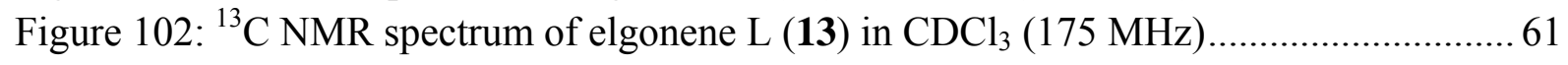

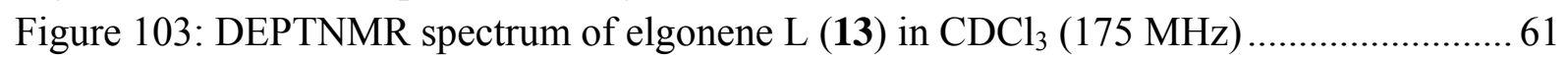

Figure 104: ${ }^{1} \mathrm{H},{ }^{13} \mathrm{C}$ HSQC NMR spectrum of elgonene $\mathrm{L}(13)$ in $\mathrm{CDCl}_{3}(700 \mathrm{MHz}, 175 \mathrm{MHz})$

Figure 105: ${ }^{1} \mathrm{H},{ }^{13} \mathrm{C}$ HMBC NMR spectrum of elgonene $\mathrm{L}$ (13) in $\mathrm{CDCl}_{3}(700 \mathrm{MHz}, 175 \mathrm{MHz})$

Figure 106: ${ }^{1} \mathrm{H},{ }^{1} \mathrm{H}$ COSY NMR spectrum of elgonene L (13) in $\mathrm{CDCl}_{3}(700 \mathrm{MHz}) \ldots \ldots \ldots \ldots . .63$

Figure 107: ${ }^{1} \mathrm{H},{ }^{1} \mathrm{H}$ ROESY NMR spectrum of elgonene $\mathrm{L}(\mathbf{1 3})$ in $\mathrm{CDCl}_{3}(700 \mathrm{MHz})$......... 63

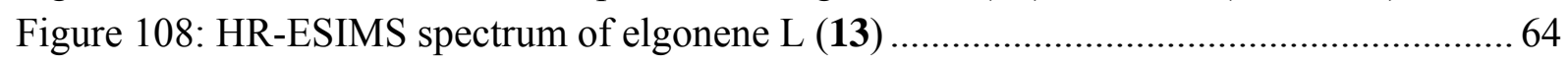

Figure 109: RAxML phylogenetic tree of the 20 closest ITS BLAST results ........................ 67 


\section{LIST OF TABLES}

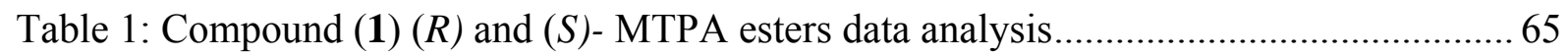

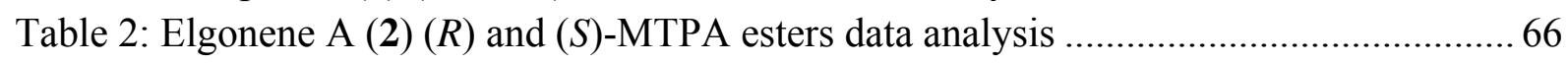

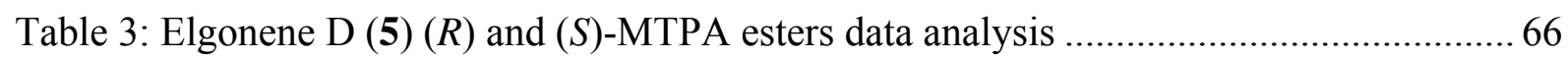


1 and 2D NMR data for $(6 R, 7 S, 10 R)-7,10$-epoxy-7,11-dimethyldodec-1-ene-6,11-diol (1) Figure 1: ${ }^{1} \mathrm{H}$ NMR spectrum of $(6 R, 7 S, 10 R)$-7,10-epoxy-7,11-dimethyldodec-1-ene-6,11-diol (1) in acetone- $\mathrm{d}_{6}(700 \mathrm{MHz})$

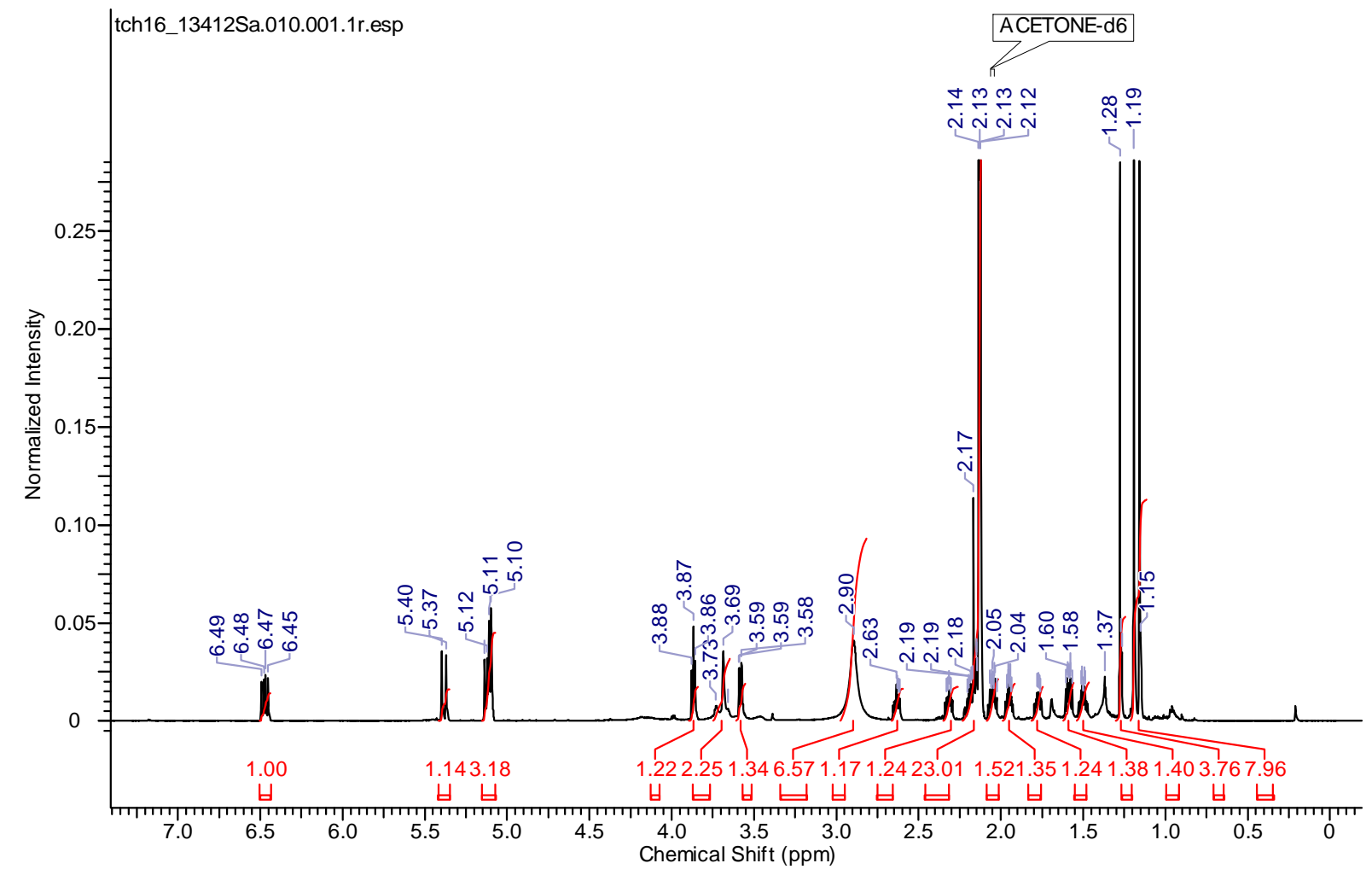

Figure $2:{ }^{13} \mathrm{C}$ NMR spectrum of $(6 R, 7 S, 10 R)$-7,10-epoxy-7,11-dimethyldodec-1-ene-6,11-diol (1) in acetone- $\mathrm{d}_{6}(175 \mathrm{MHz})$

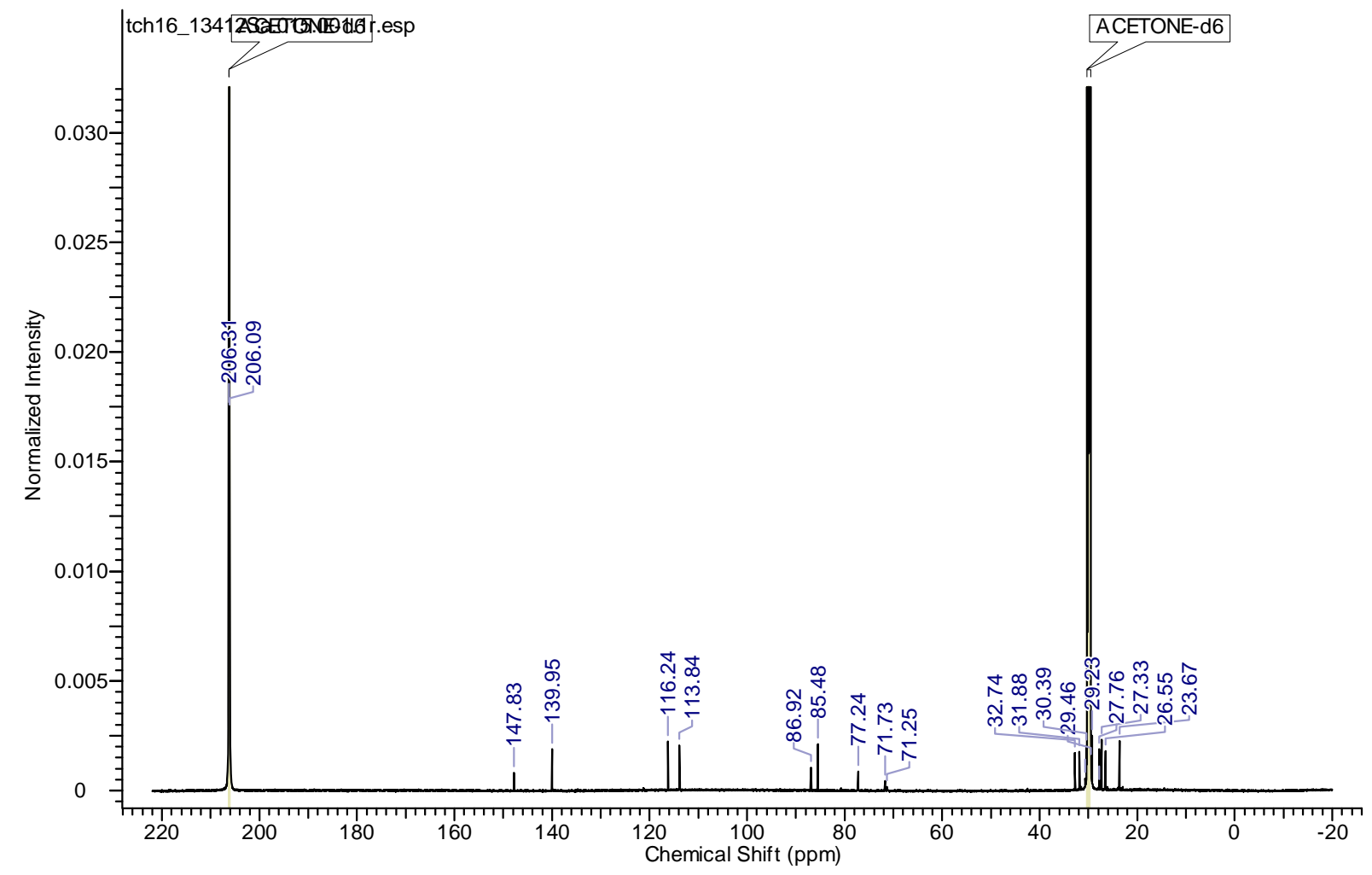


Figure 3: DEPT spectrum of $(6 R, 7 S, 10 R)$-7,10-epoxy-7,11-dimethyldodec-1-ene-6,11-diol (1) in acetone- $\mathrm{d}_{6}(175 \mathrm{MHz})$

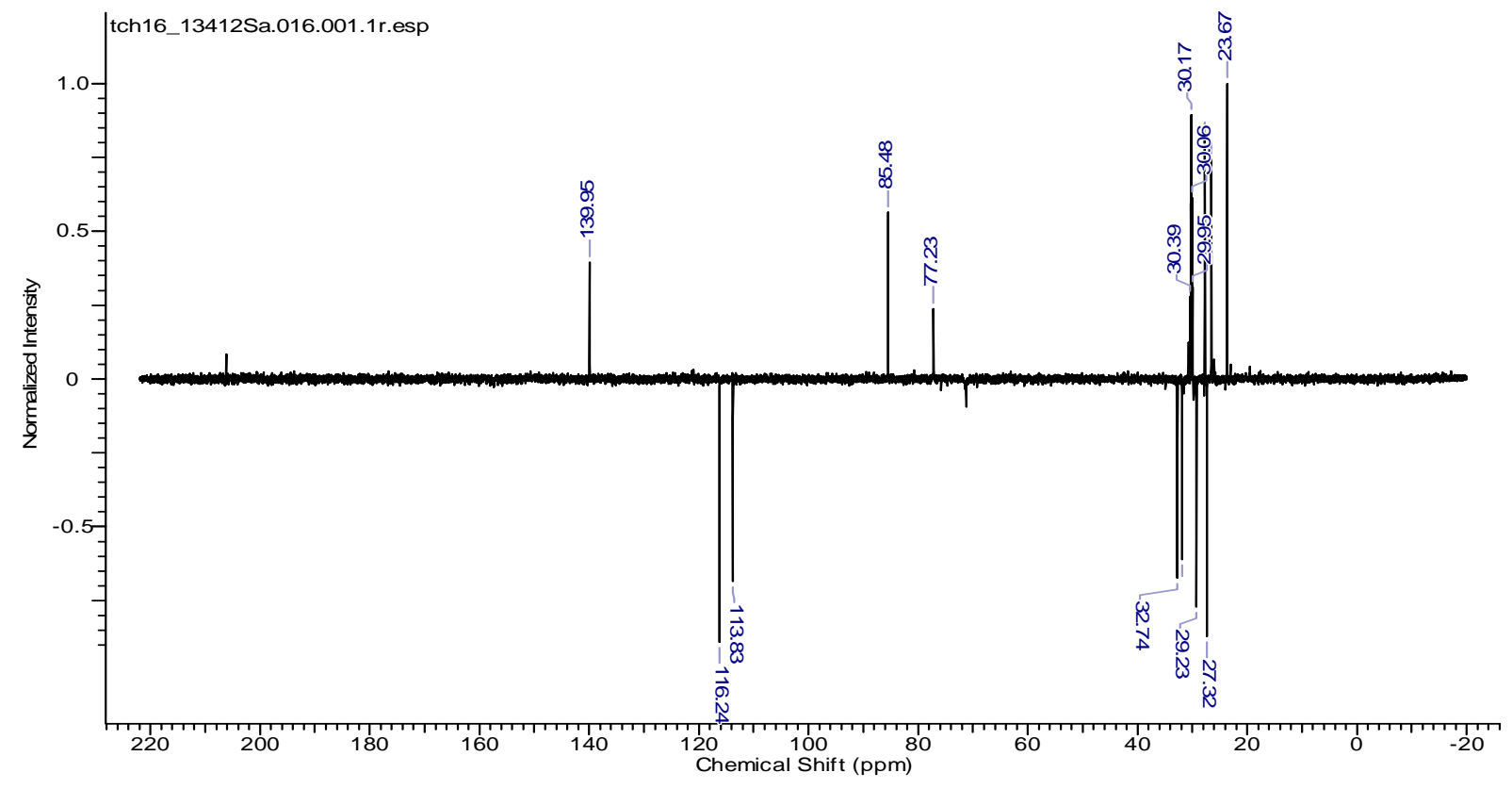

Figure $4:{ }^{1} \mathrm{H},{ }^{13} \mathrm{C}$ HSQC spectrum of $(6 R, 7 S, 10 R)$-7,10-epoxy-7,11-dimethyldodec-1-ene6,11-diol (1) in acetone- $\mathrm{d}_{6}(700 \mathrm{MHz}, 175 \mathrm{MHz})$

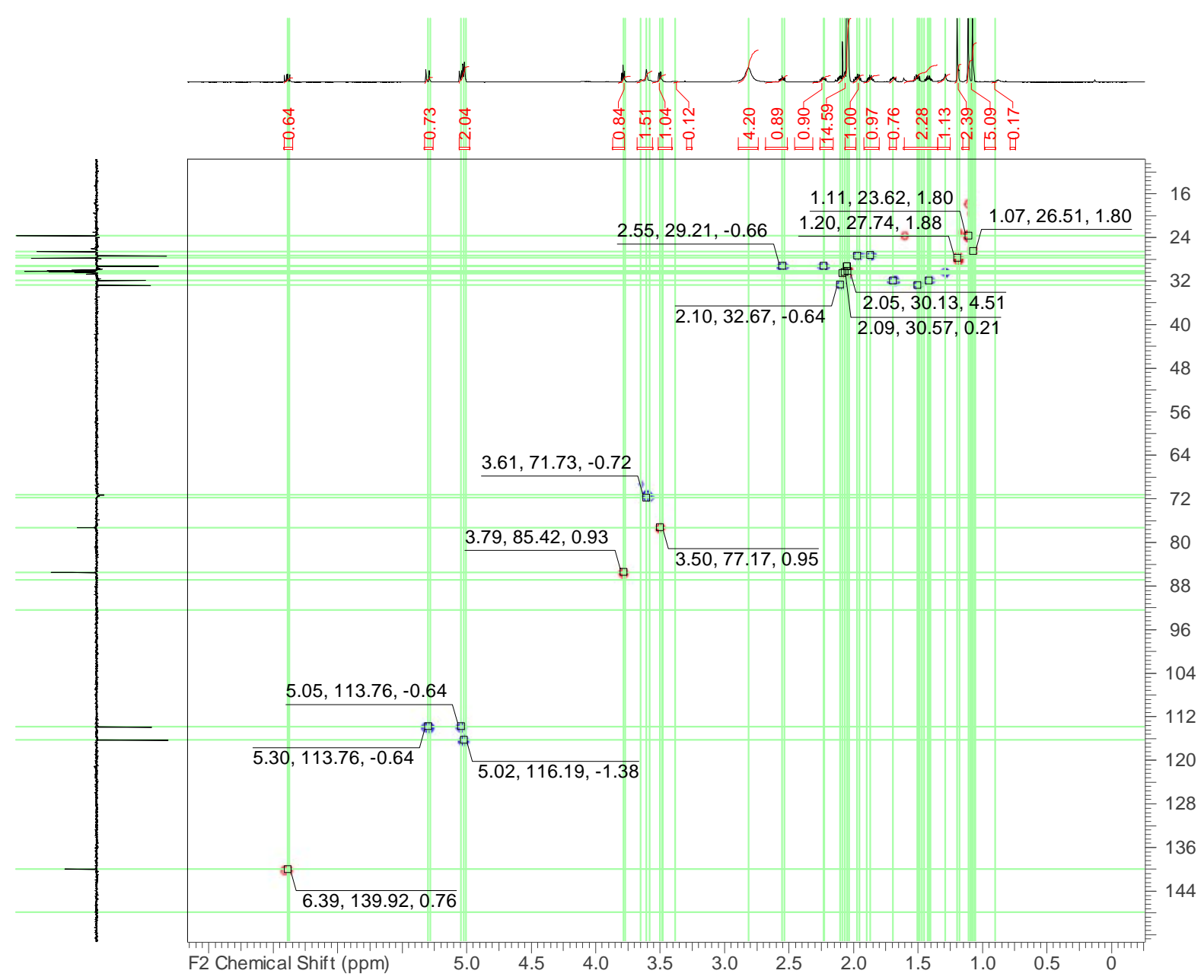


Figure 5: ${ }^{1} \mathrm{H},{ }^{13} \mathrm{C}$ HMBC spectrum of $(6 R, 7 S, 10 R)$-7, 10-epoxy-7,11-dimethyldodec-1-ene6,11-diol (1) in acetone- $\mathrm{d}_{6}(700 \mathrm{MHz}, 175 \mathrm{MHz})$

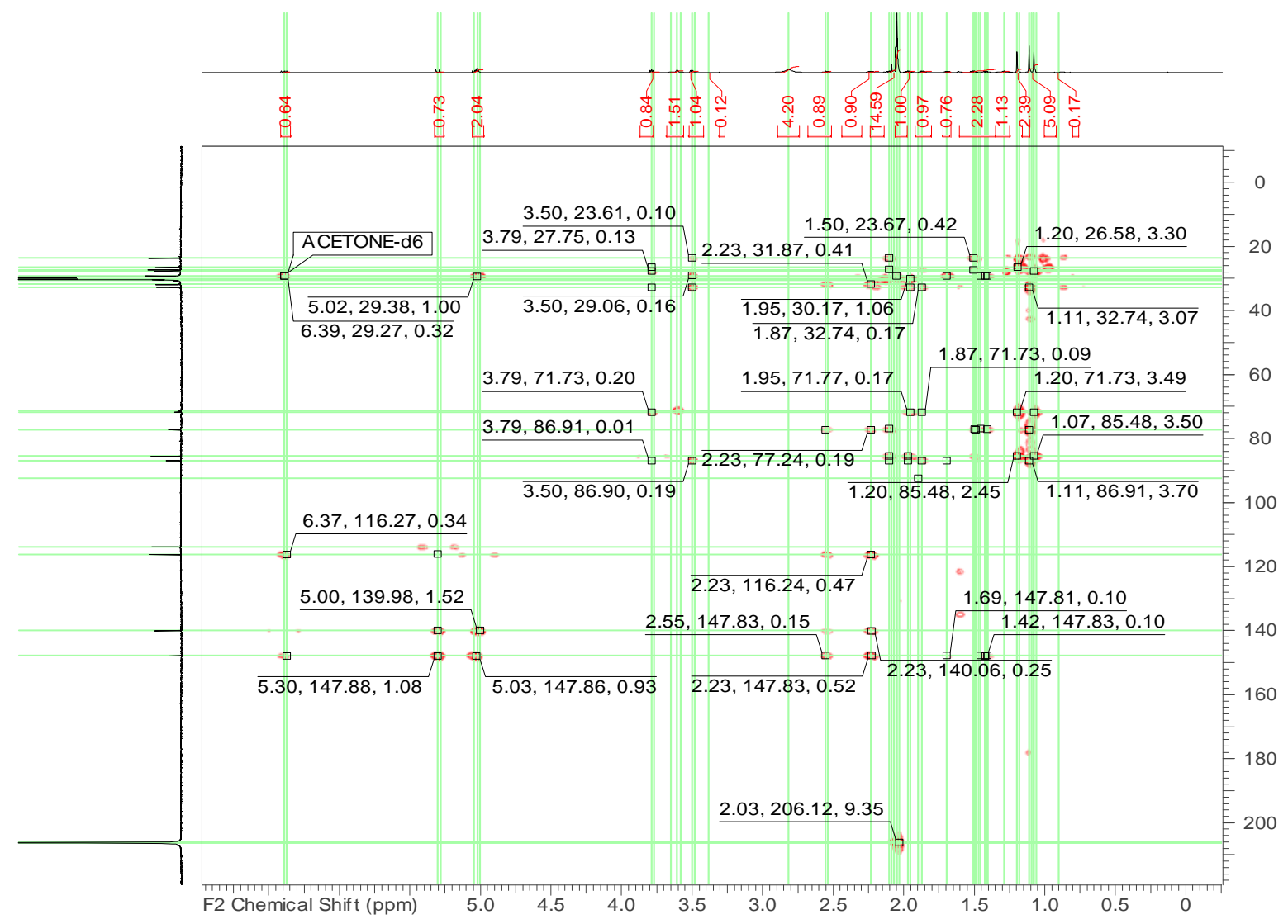


Figure 6: ${ }^{1} \mathrm{H},{ }^{1} \mathrm{H}$ COSY NMR spectrum of $(6 R, 7 S, 10 R)-7,10$-epoxy-7,11-dimethyldodec-1ene-6,11-diol (1) in acetone- $\mathrm{d}_{6}(700 \mathrm{MHz})$

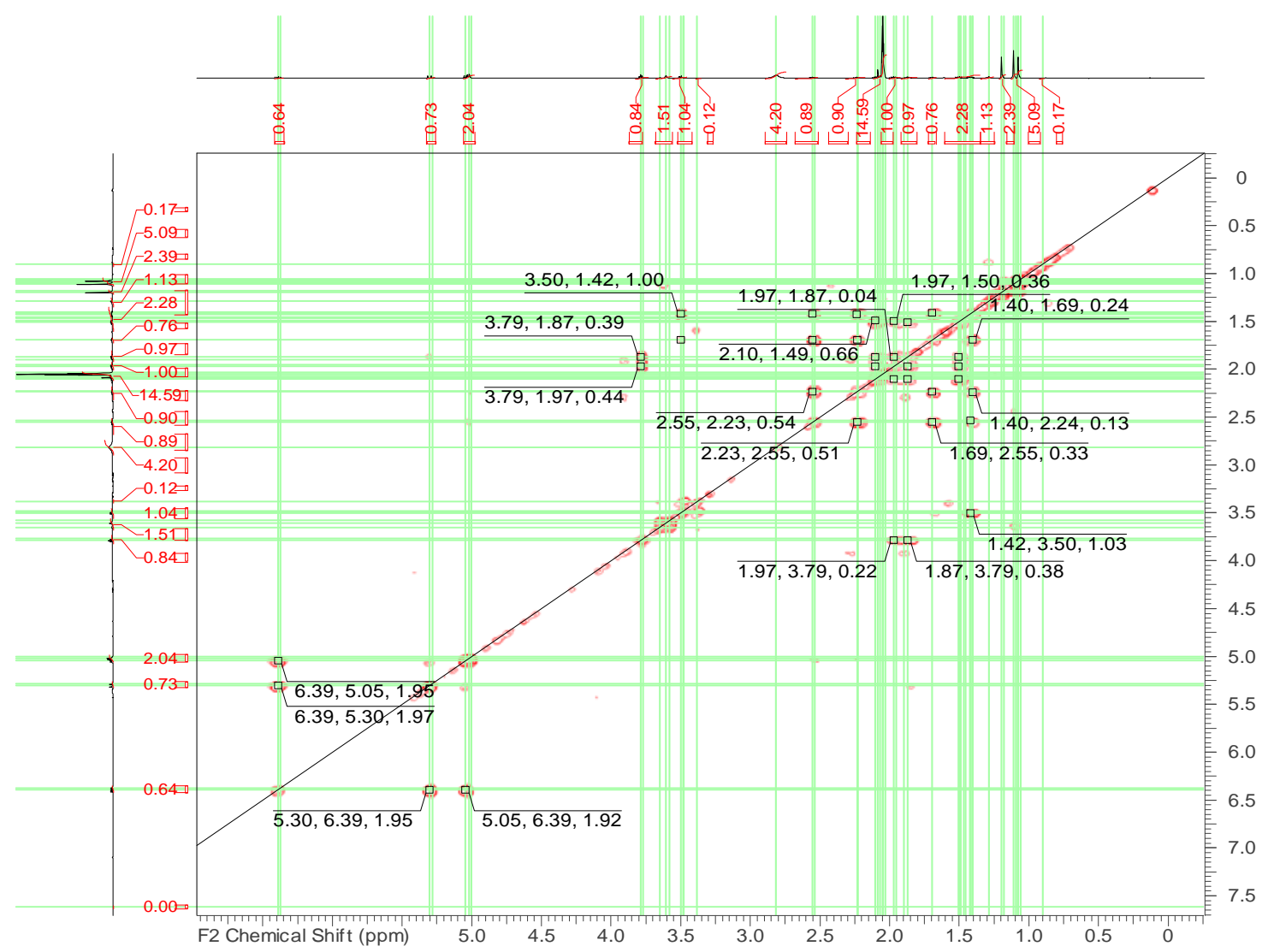

Figure 7: 1H, 1H ROESY NMR spectrum of (6R,7S,10R)-7,10-epoxy-7,11-dimethyldodec-1ene-6,11-diol (1) in acetone-d6 (700MHz)

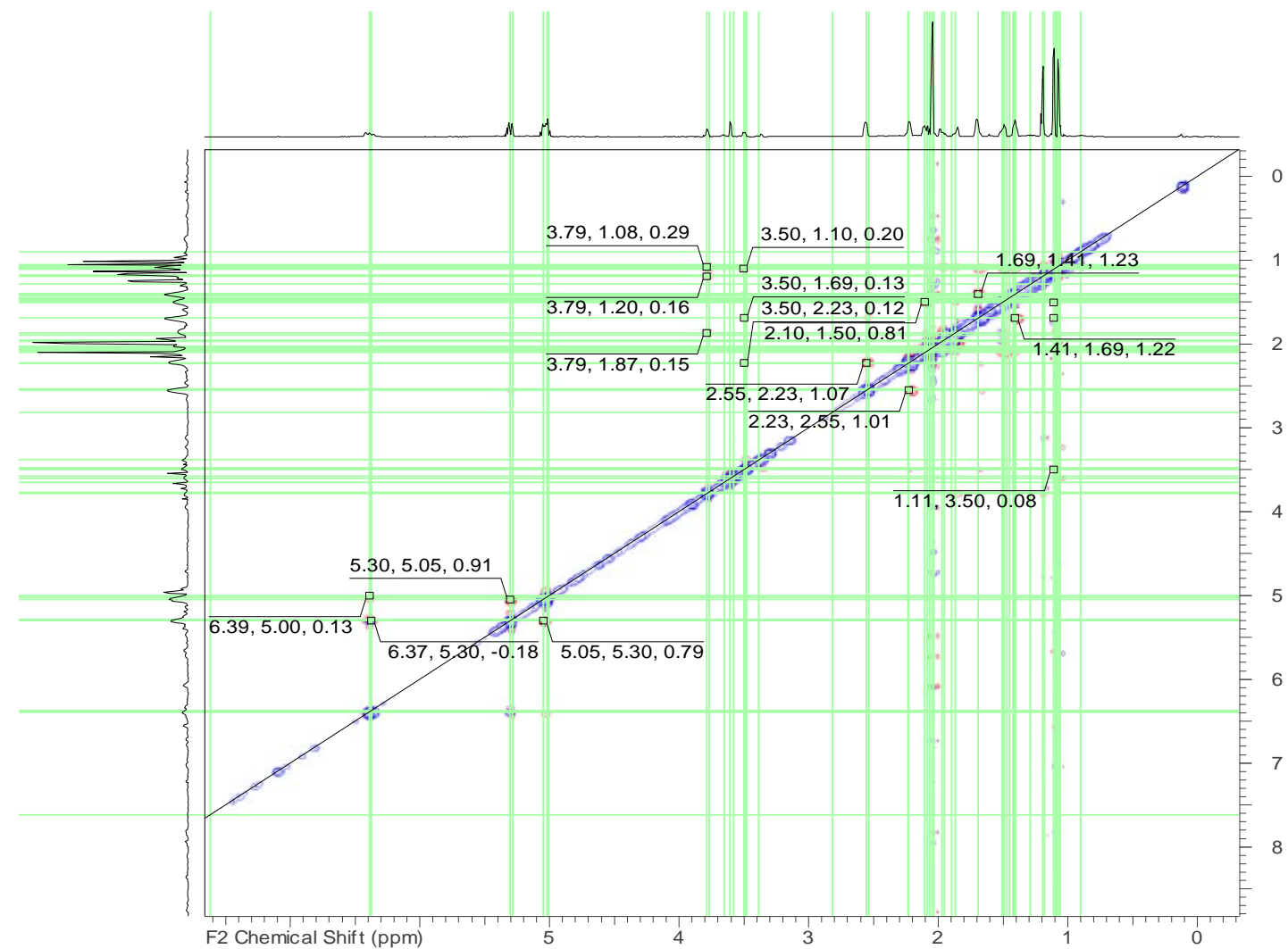


Figure 8: HR-ESIMS spectrum for $(6 R, 7 S, 10 R)$-7,10-epoxy-7,11-dimethyldodec-1-ene-6,11diol (1)

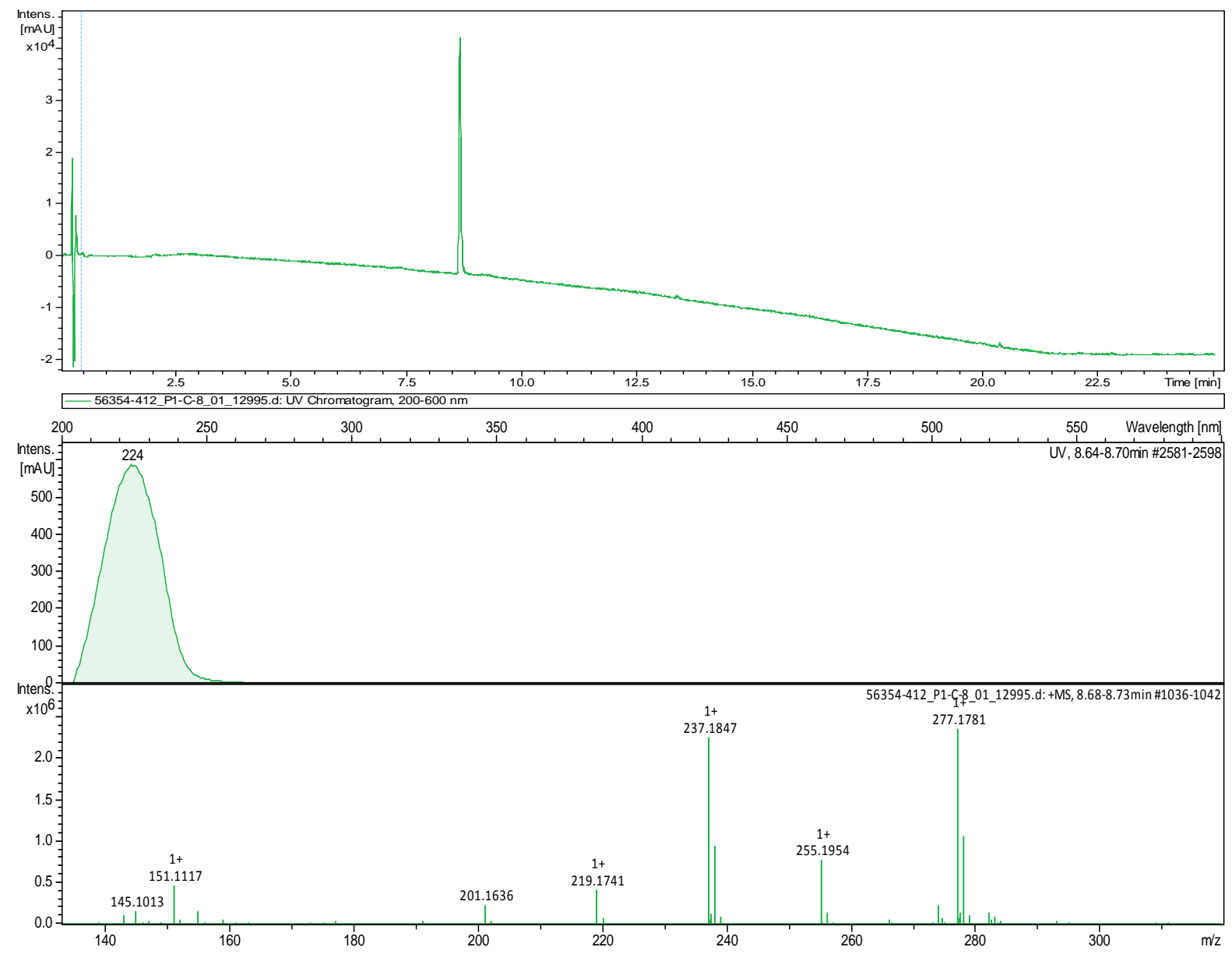

Figure 9: ${ }^{1} \mathrm{H}$ NMR spectrum of $(6 R, 7 S, 10 R)$-7,10-epoxy-7,11-dimethyldodec-1-ene-6,11-diol (1) $S$-MTPA ester in pyridine-d $\mathrm{d}_{5}(700 \mathrm{MHz})$

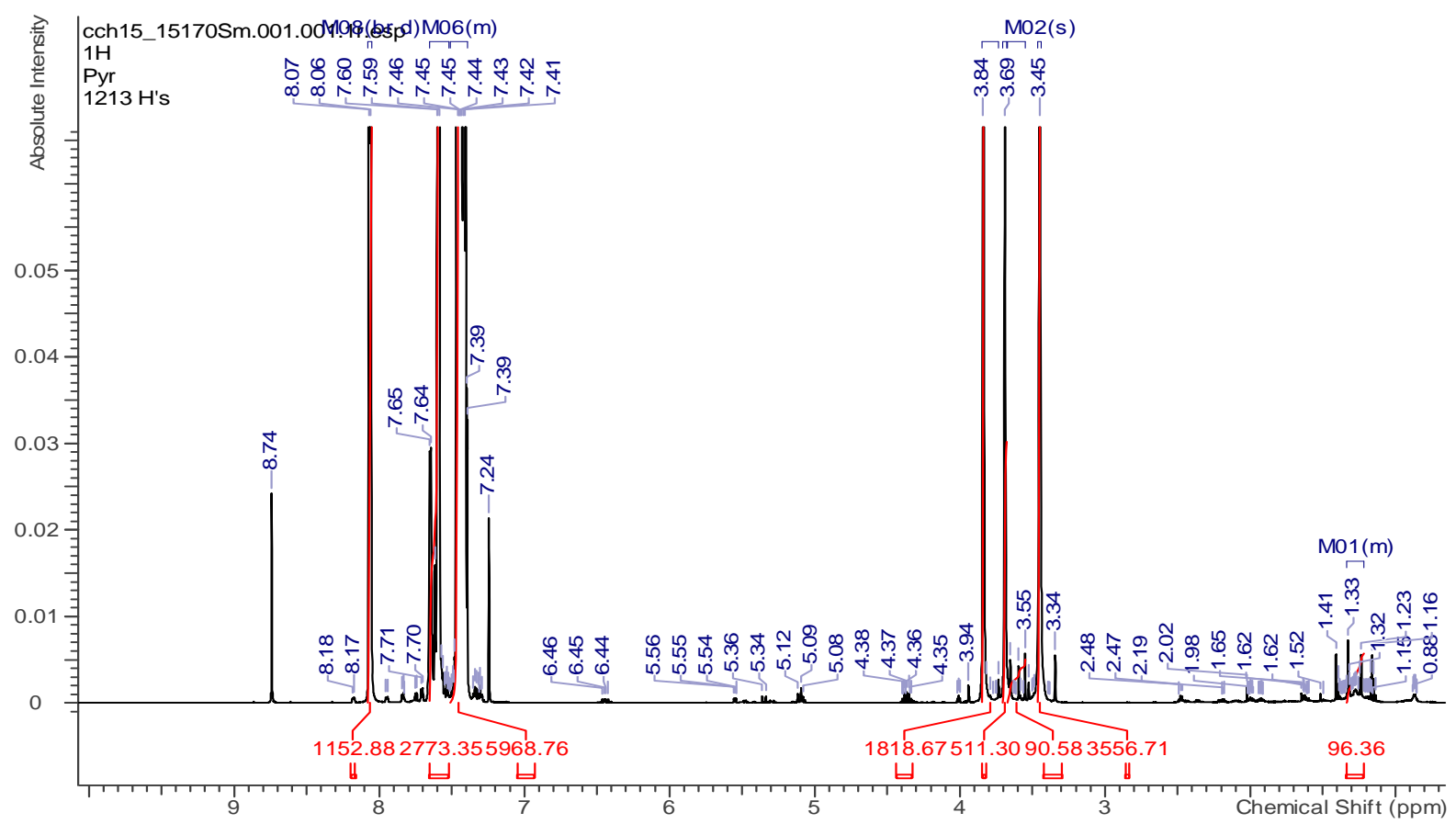


Figure 10: ${ }^{1} \mathrm{H}{ }^{1} \mathrm{H}$ COSY NMR spectrum of $(6 R, 7 S, 10 R)$-7,10-epoxy-7,11-dimethyldodec-1ene-6,11-diol (1) $S$-MTPA ester in pyridine-d ${ }_{5}(700 \mathrm{MHz})$

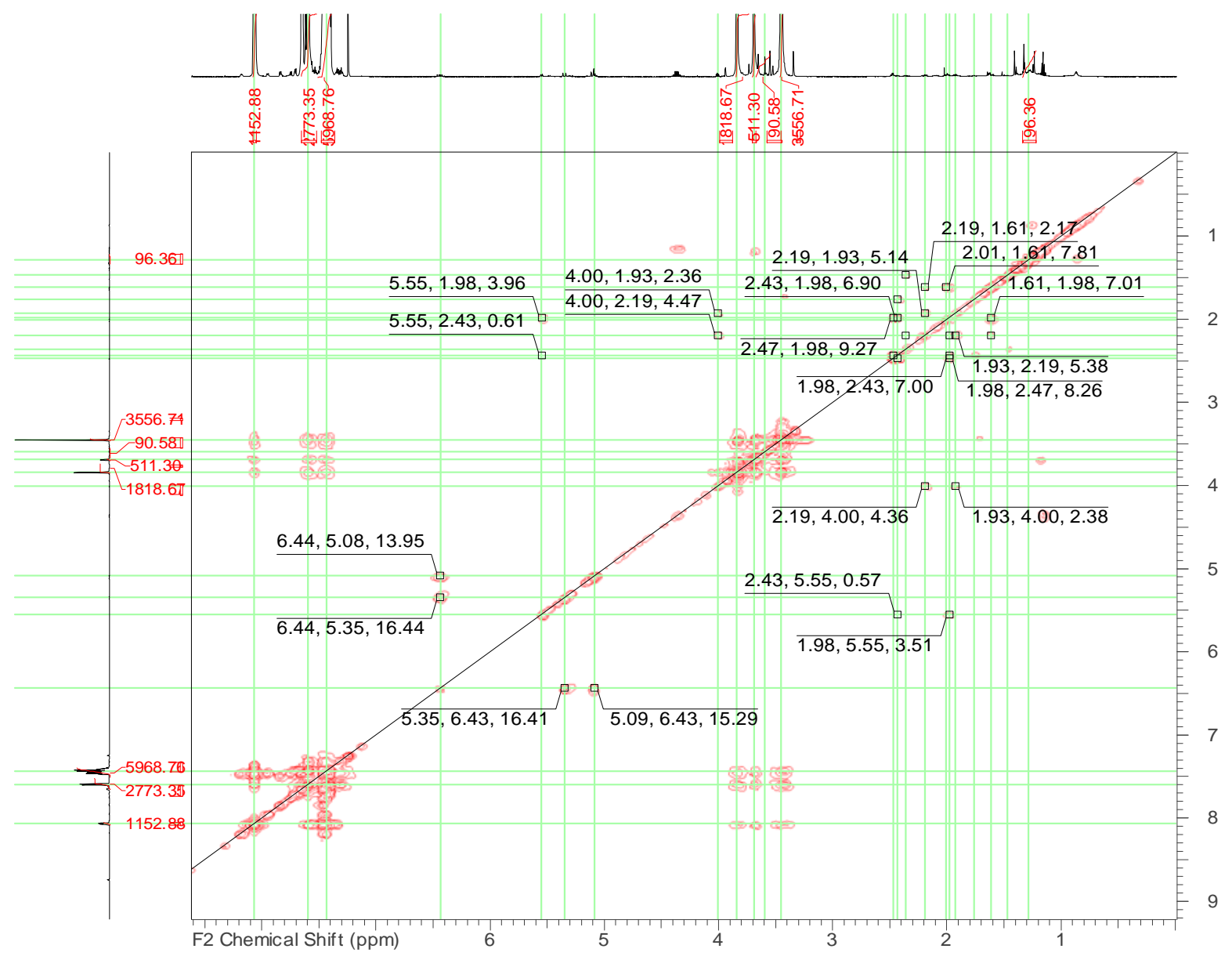

Figure 11: ${ }^{1} \mathrm{H}$ NMR spectrum of $(6 R, 7 S, 10 R)$-7,10-epoxy-7,11-dimethyldodec-1-ene-6,11-diol (1) $R$-MTPA ester in pyridine- $\mathrm{d}_{5}(700 \mathrm{MHz})$

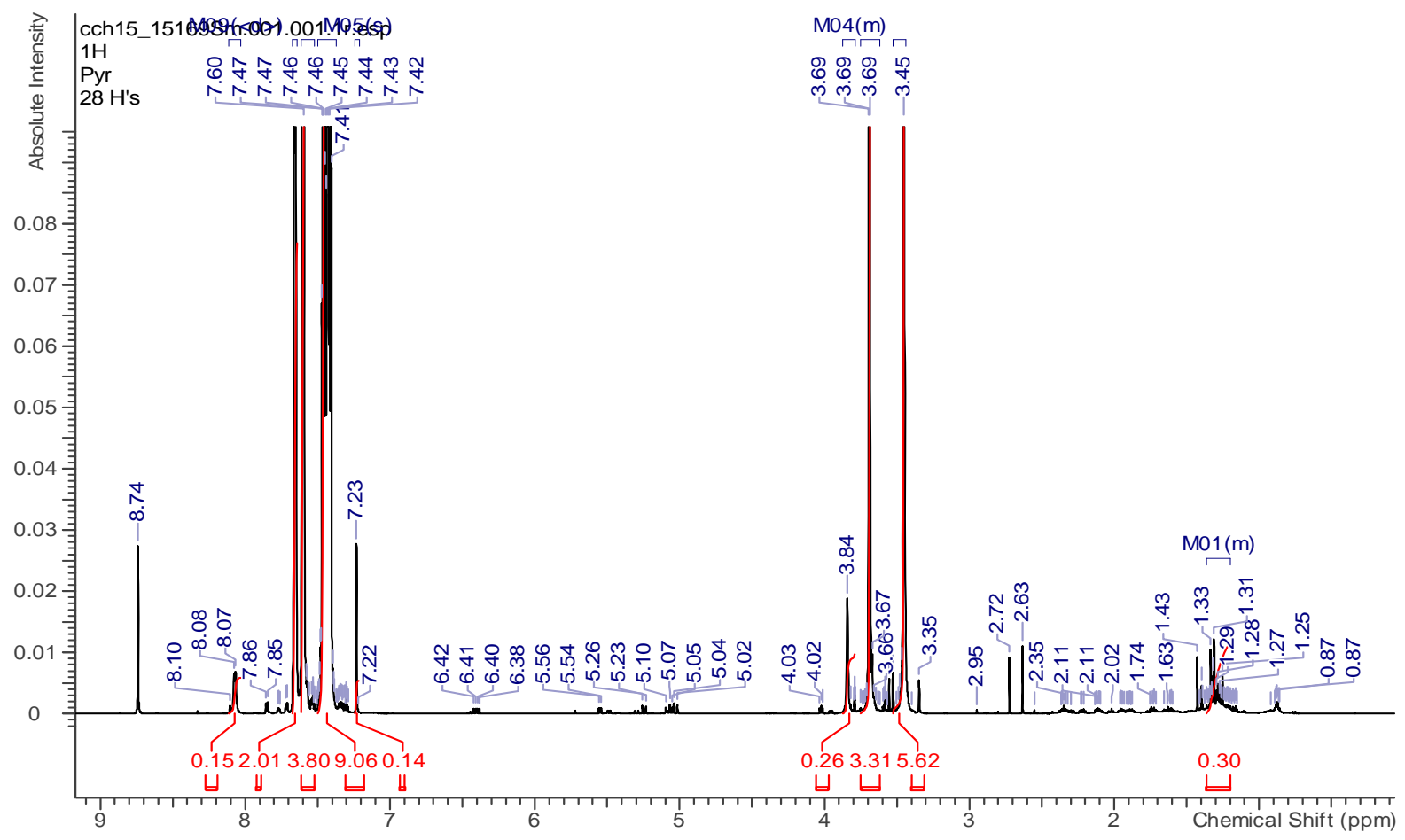


Figure 12: ${ }^{1} \mathrm{H}{ }^{1} \mathrm{H}$ COSY NMR spectrum of $(6 \mathrm{R}, 7 \mathrm{~S}, 10 \mathrm{R})-7,10$-epoxy-7,11-dimethyldodec-1ene-6,11-diol (1) R-MTPA ester in pyridine-d ${ }_{5}(700 \mathrm{MHz})$

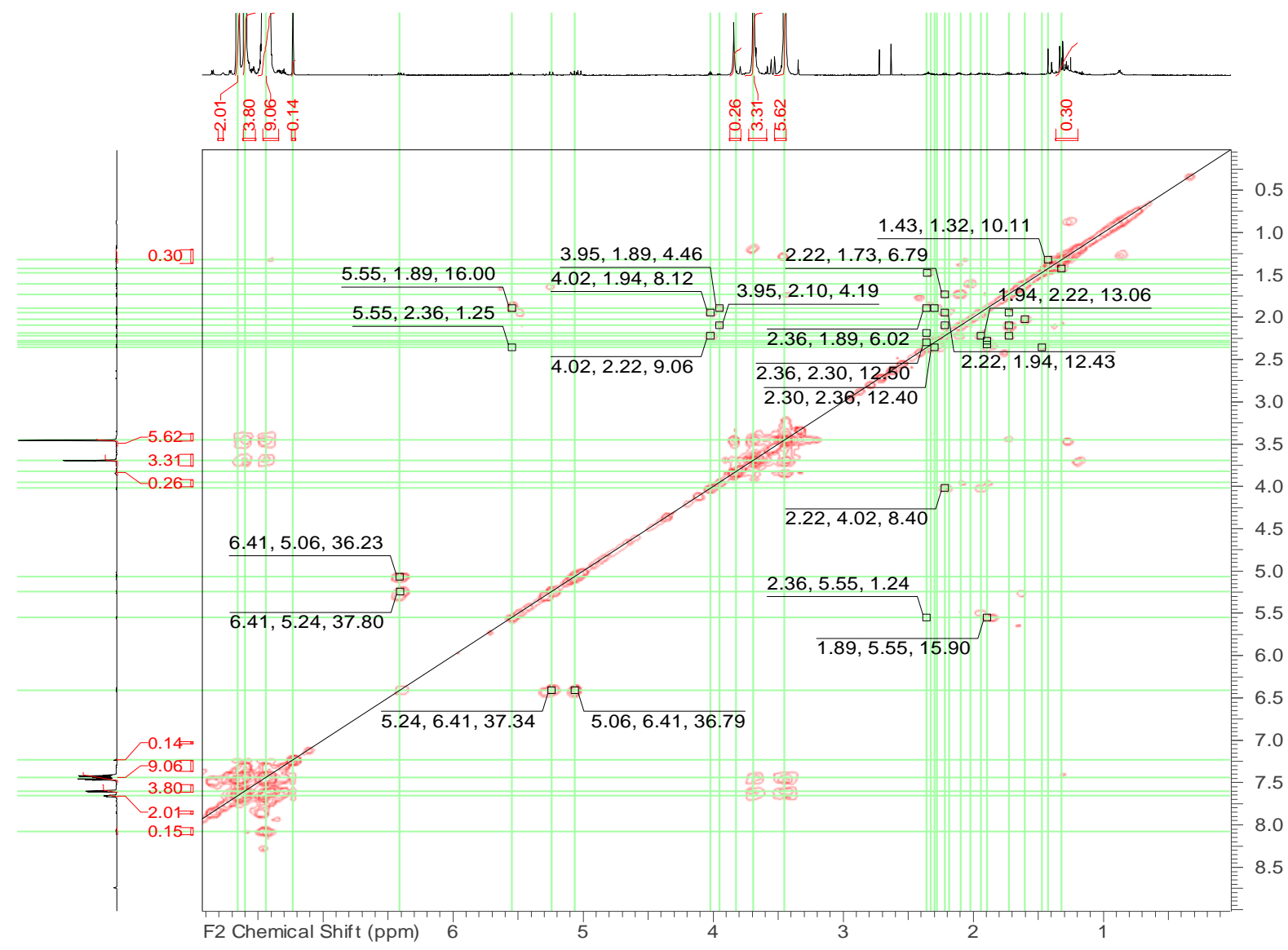

\section{1 and 2D NMR data for elgonene A (2)}

Figure 13: ${ }^{1} \mathrm{H}$ NMR spectrum of elgonene A (2) in $\mathrm{CDCl}_{3}(500 \mathrm{MHz})$ 


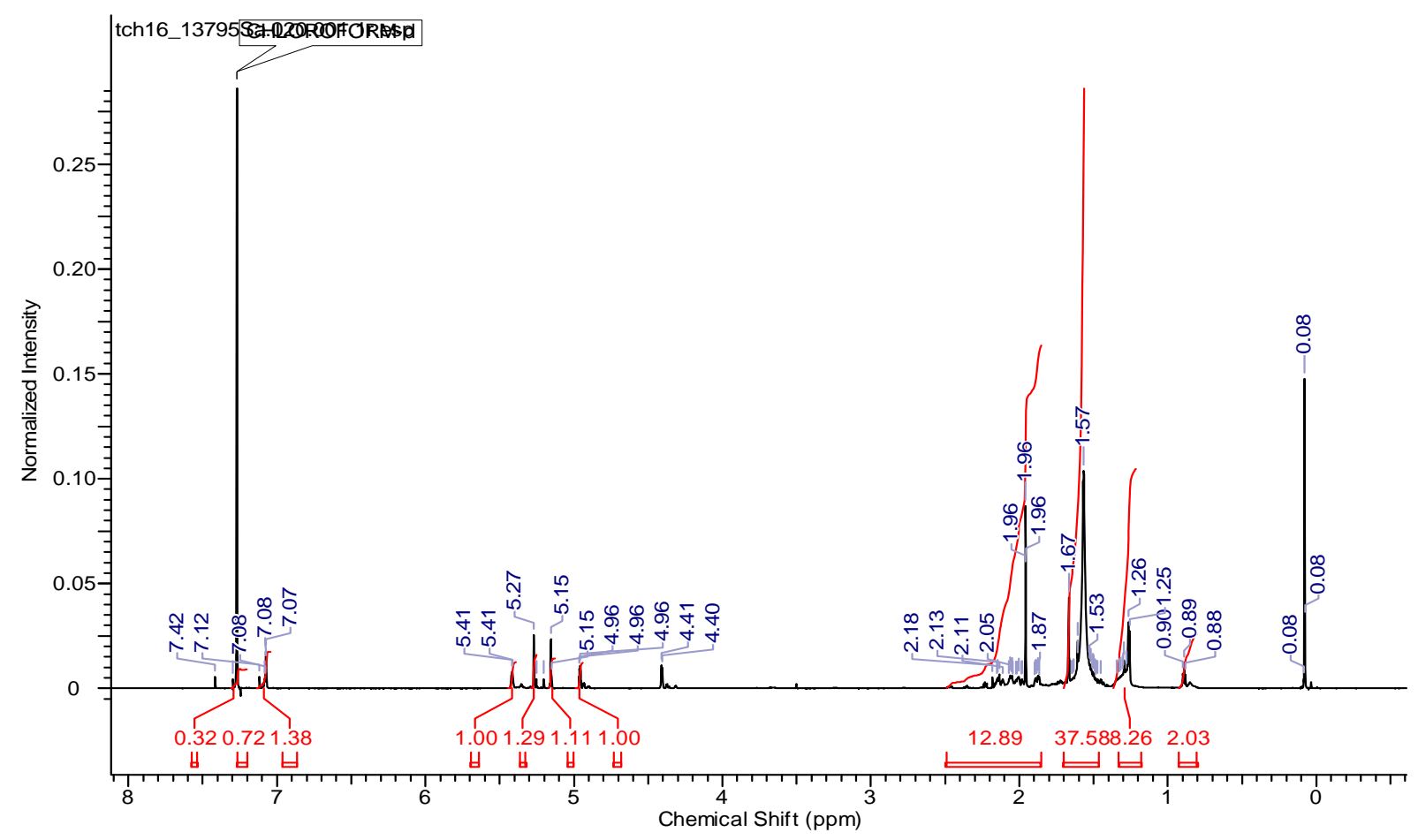

Figure 14: ${ }^{13} \mathrm{C}$ NMR spectrum of elgonene $\mathrm{A}(2)$ in $\mathrm{CDCl}_{3}(125 \mathrm{MHz})$

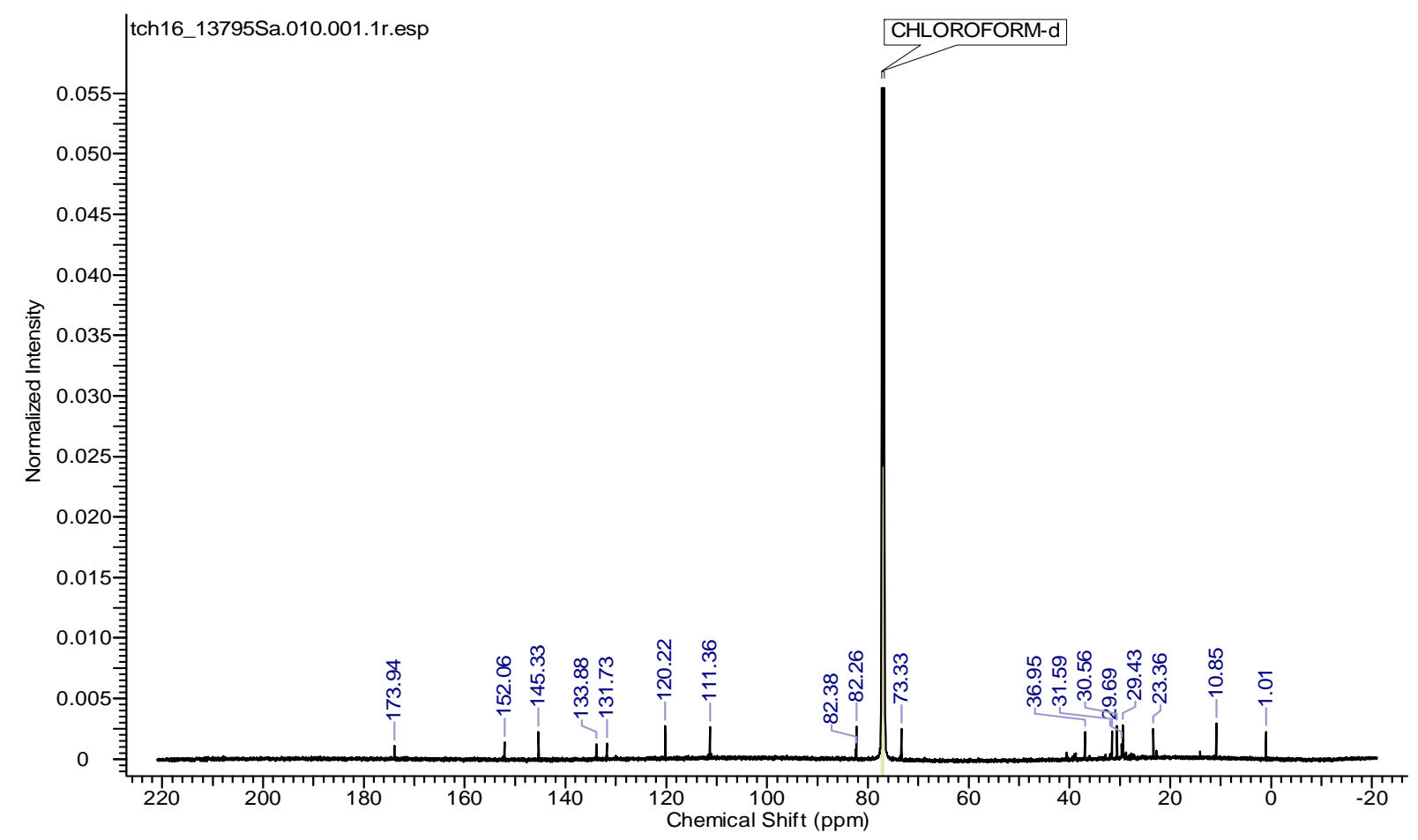

Figure 15: DEPT NMR spectrum of elgonene A (2) in $\mathrm{CDCl}_{3}(125 \mathrm{MHz})$ 


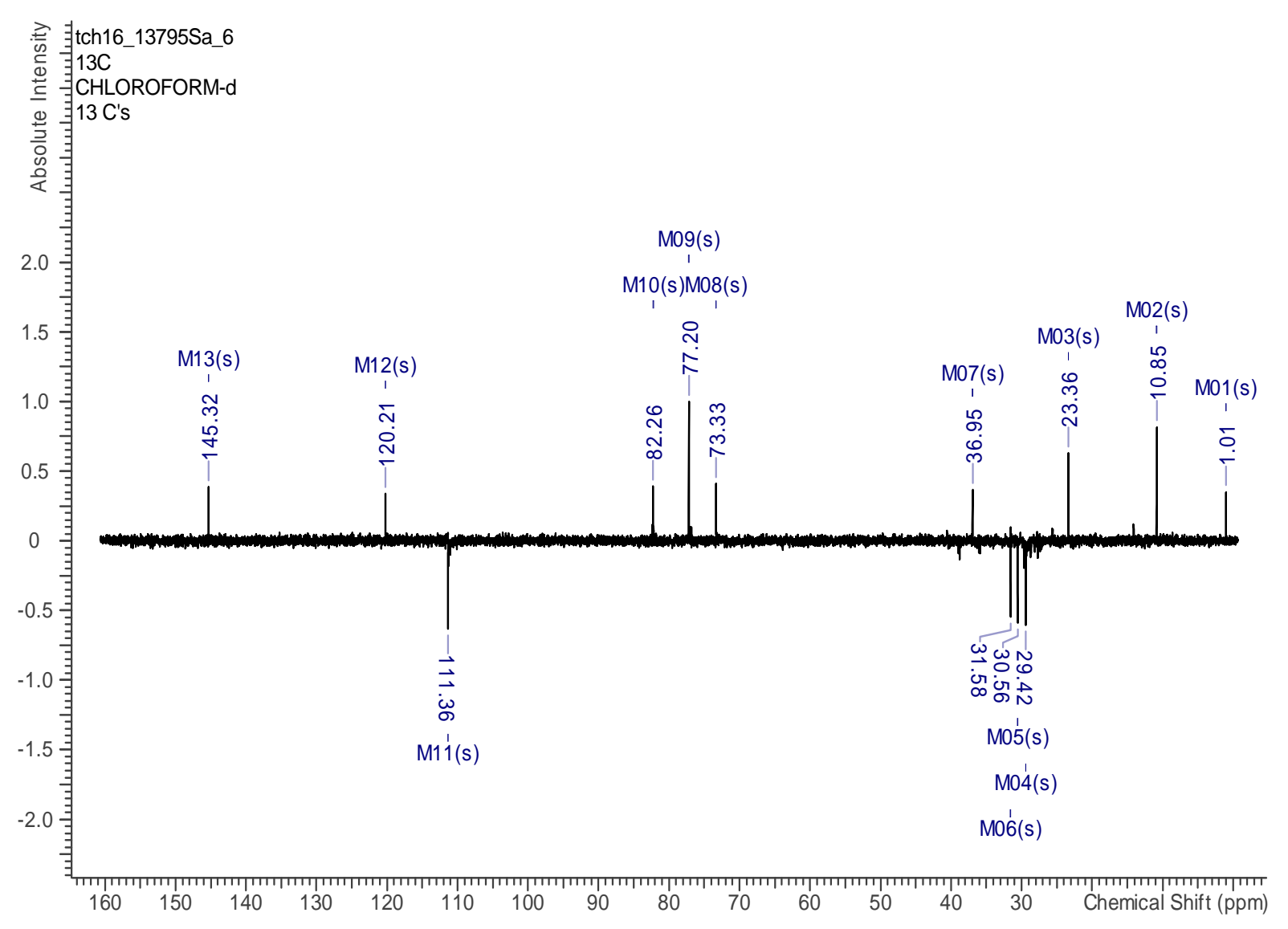

Figure 16: ${ }^{1} \mathrm{H},{ }^{13} \mathrm{C}$ HSQC NMR spectrum of elgonene A (2) in $\mathrm{CDCl}_{3}(500 \mathrm{MHz}, 125 \mathrm{MHz})$

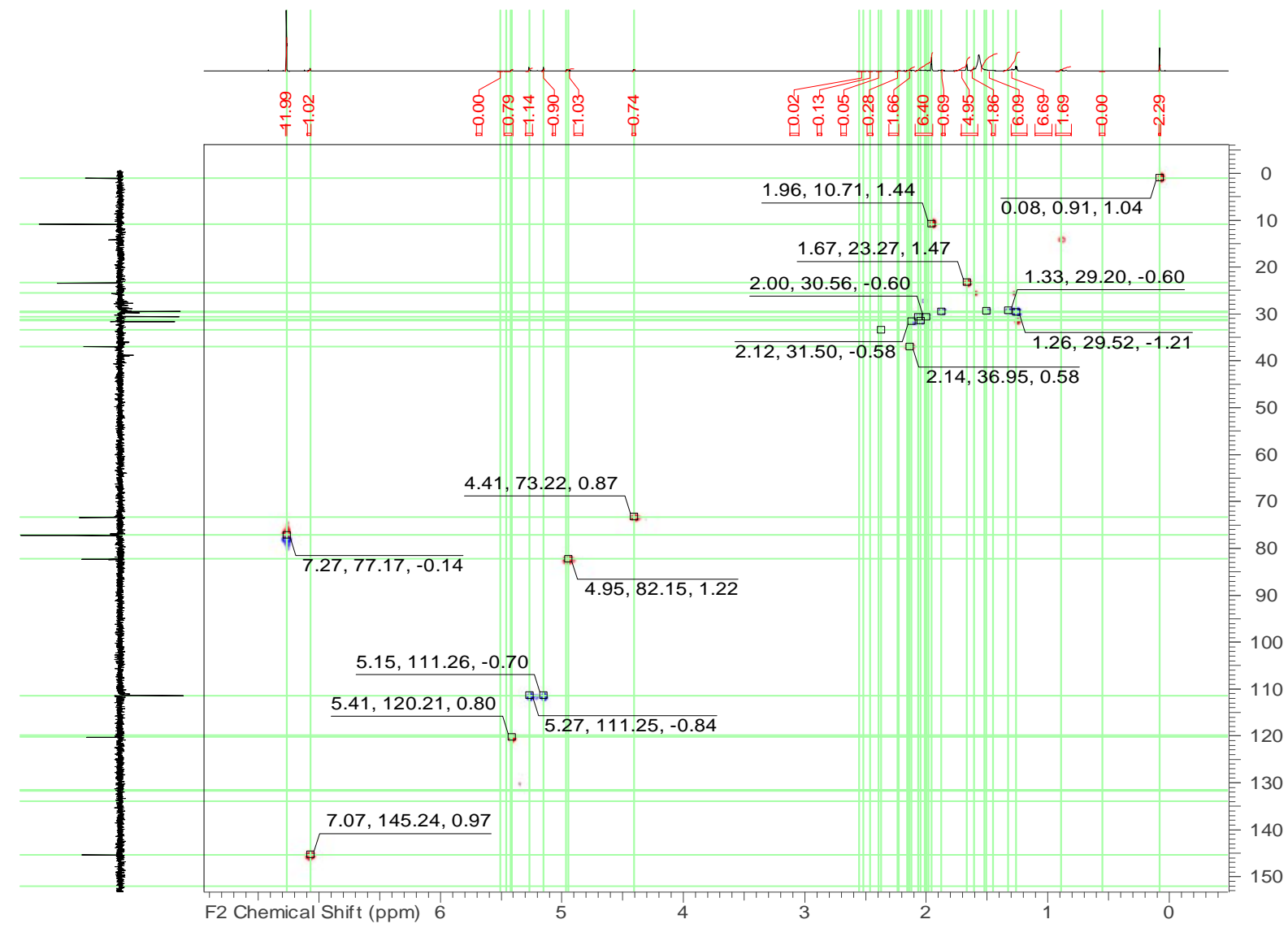


Figure 17: ${ }^{1} \mathrm{H},{ }^{13} \mathrm{C}$ HMBC NMR spectrum of elgonene A (2) in $\mathrm{CDCl}_{3}(500 \mathrm{MHz}, 125 \mathrm{MHz})$

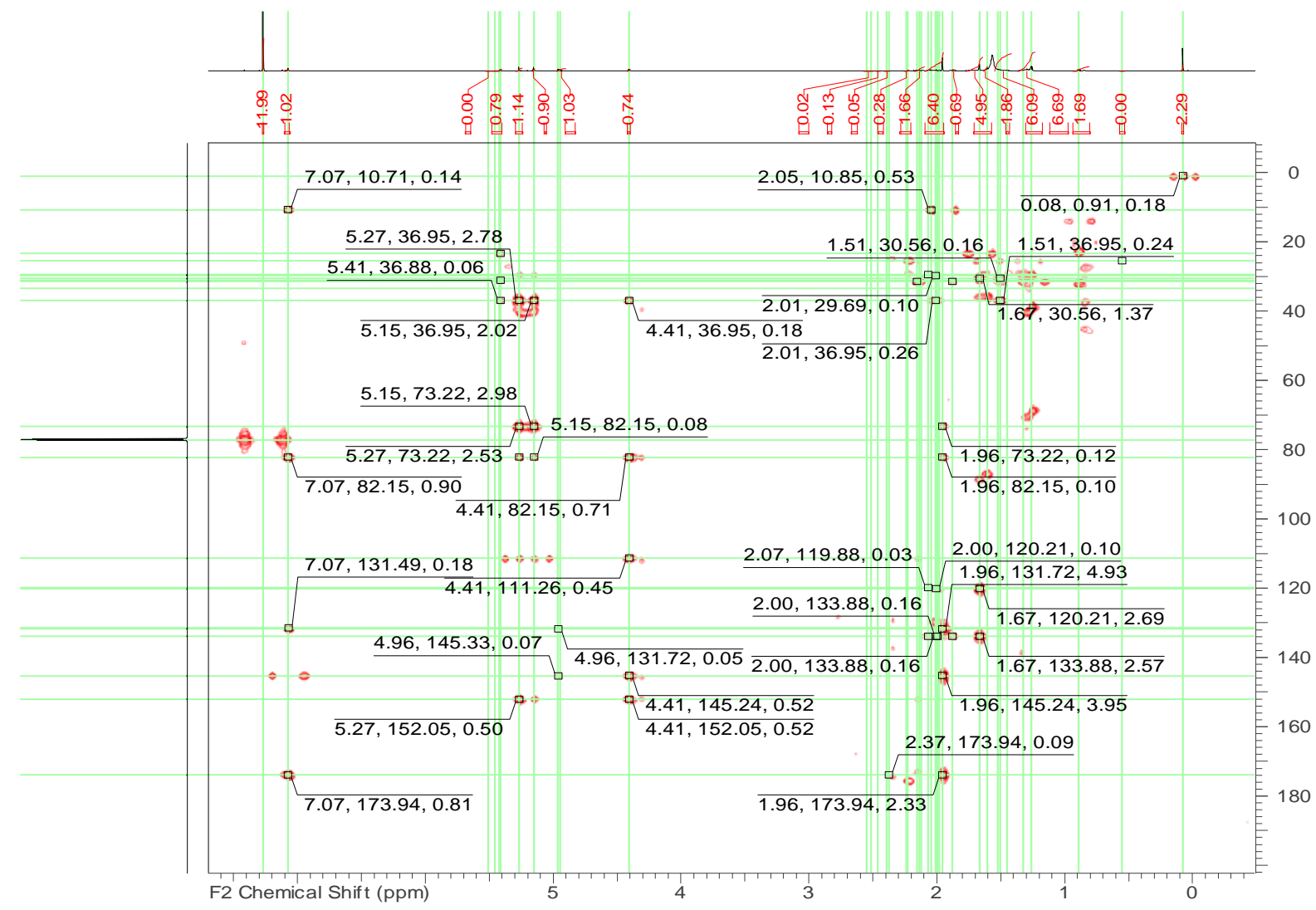

Figure 18: ${ }^{1} \mathrm{H},{ }^{1} \mathrm{H}$ COSY NMR spectrum of elgonene $\mathrm{A}(2)$ in $\mathrm{CDCl}_{3}(500 \mathrm{MHz})$ 


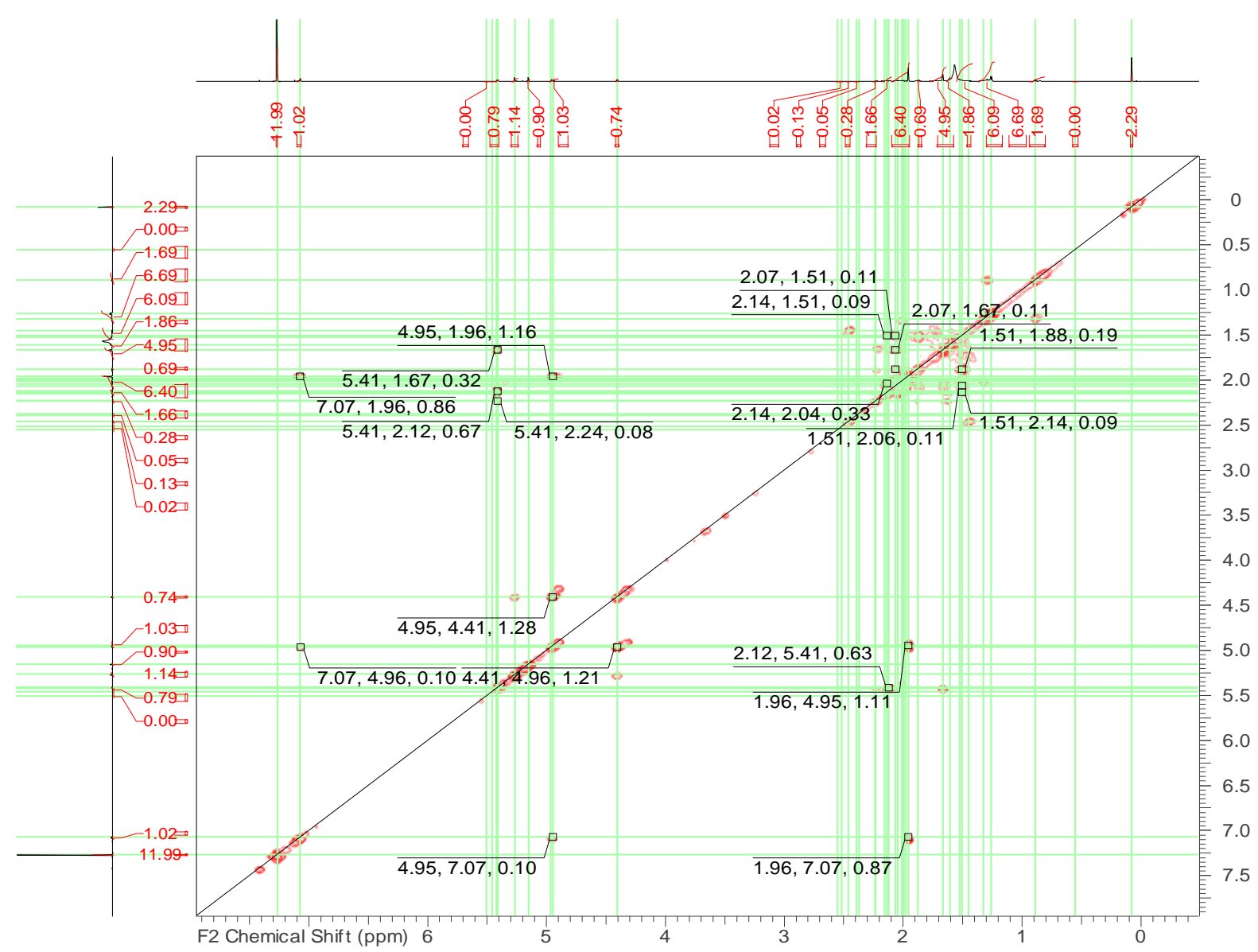

Figure 19: ${ }^{1} \mathrm{H},{ }^{1} \mathrm{H}$ ROESY NMR spectrum of elgonene A (2) in $\mathrm{CDCl}_{3}(500 \mathrm{MHz})$

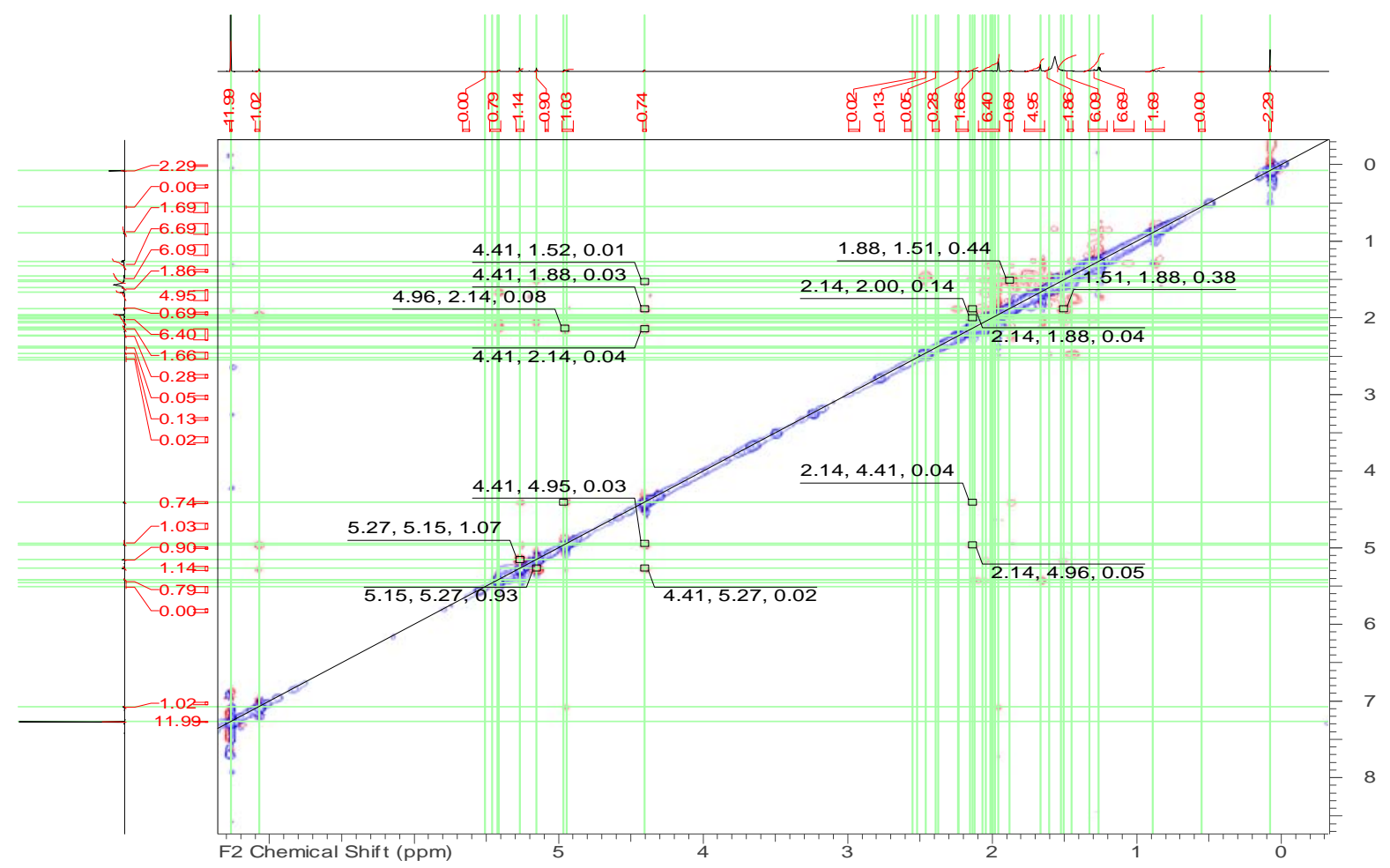

Figure 20: HR-ESIMS spectrum of elgonene A (2) 

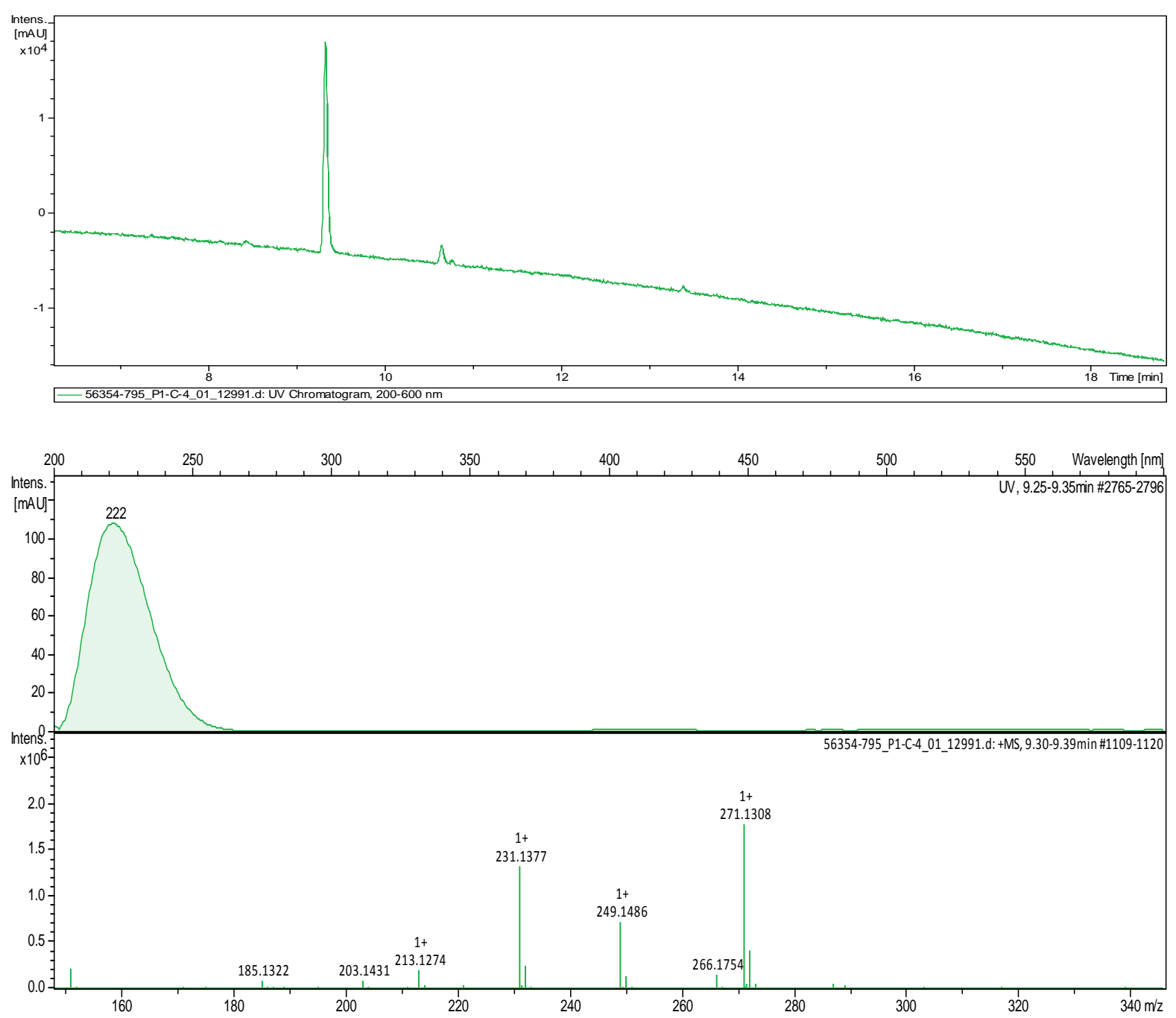

Figure 21: ${ }^{1} \mathrm{HNMR}$ spectrum of elgonene A (2) S- MTPA ester in pyridine $\mathrm{d}_{5}(700 \mathrm{MHz})$

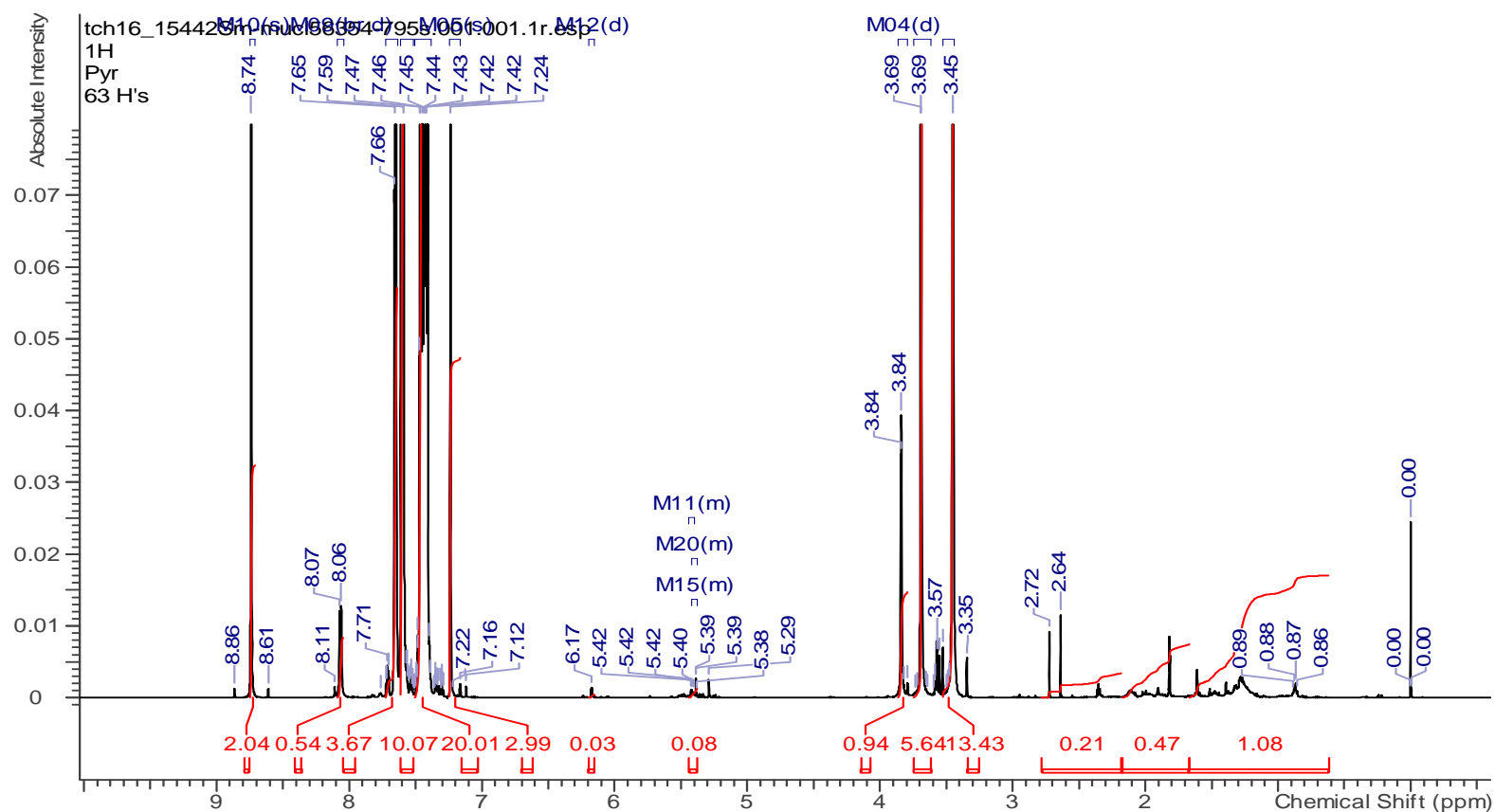


Figure 22: ${ }^{1} \mathrm{H},{ }^{1} \mathrm{H}$ COSY spectrum of elgonene A (2) $S$ - MTPA ester in pyridine $\mathrm{d}_{5}(700 \mathrm{MHz})$

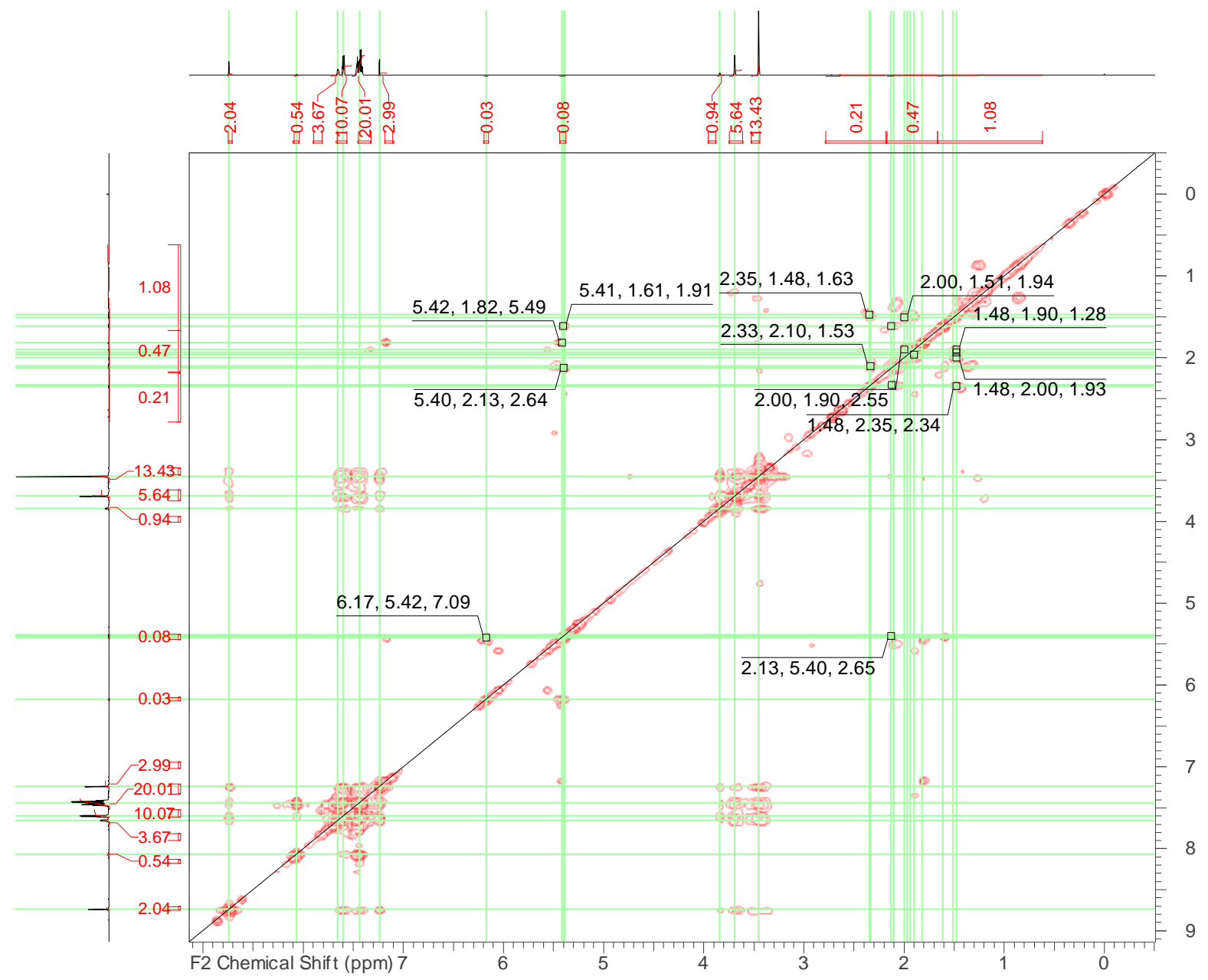

Figure 23: ${ }^{1} \mathrm{HNMR}$ spectrum of elgonene A (2) $R$ - MTPA ester in pyridine $\mathrm{d}_{5}(700 \mathrm{MHz})$

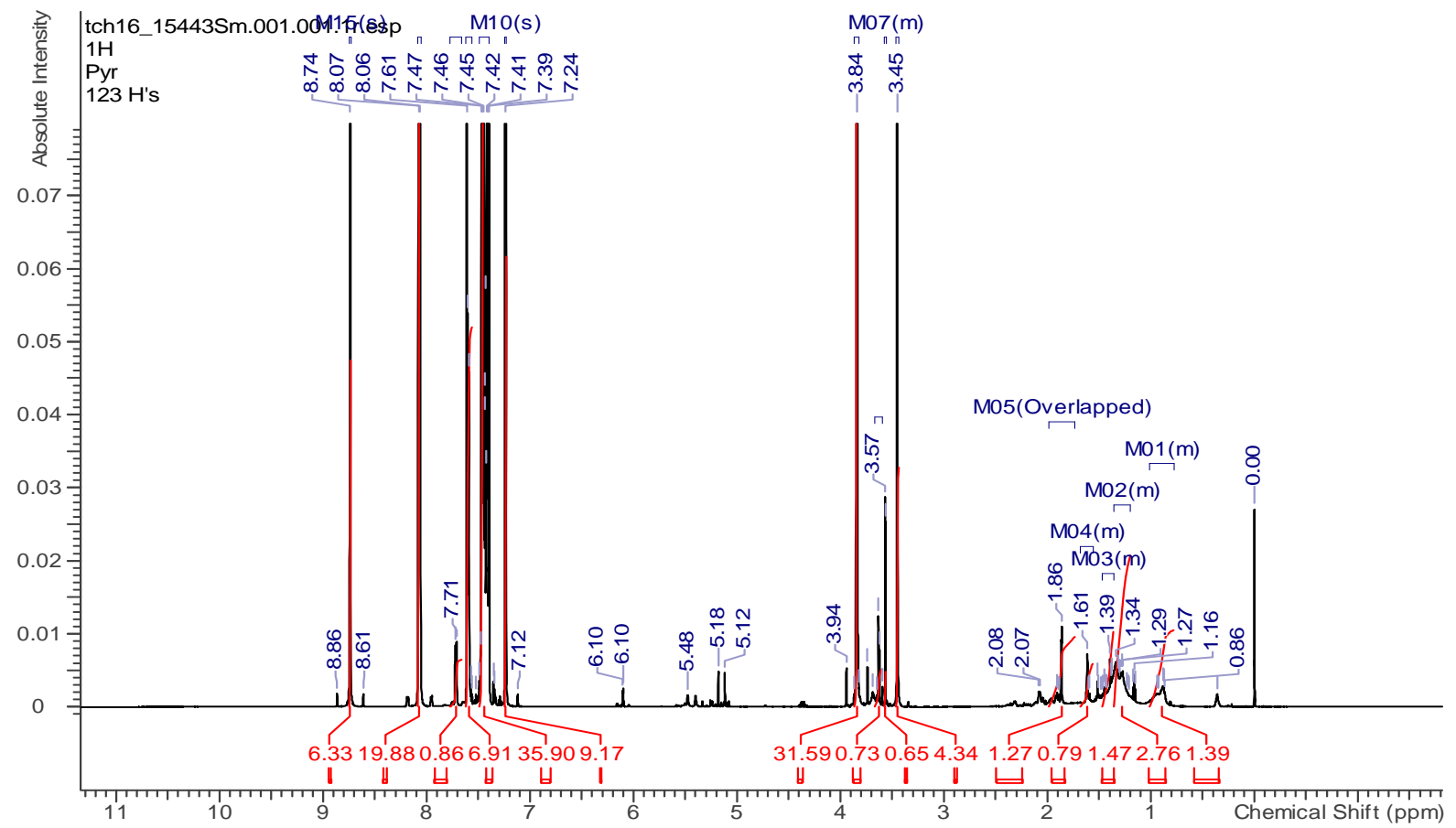


Figure 24: 1H, 1H COSY spectrum of elgonene A (2) $R$ - MTPA ester in pyridine $\mathrm{d}_{5}(700$ $\mathrm{MHz}$ )

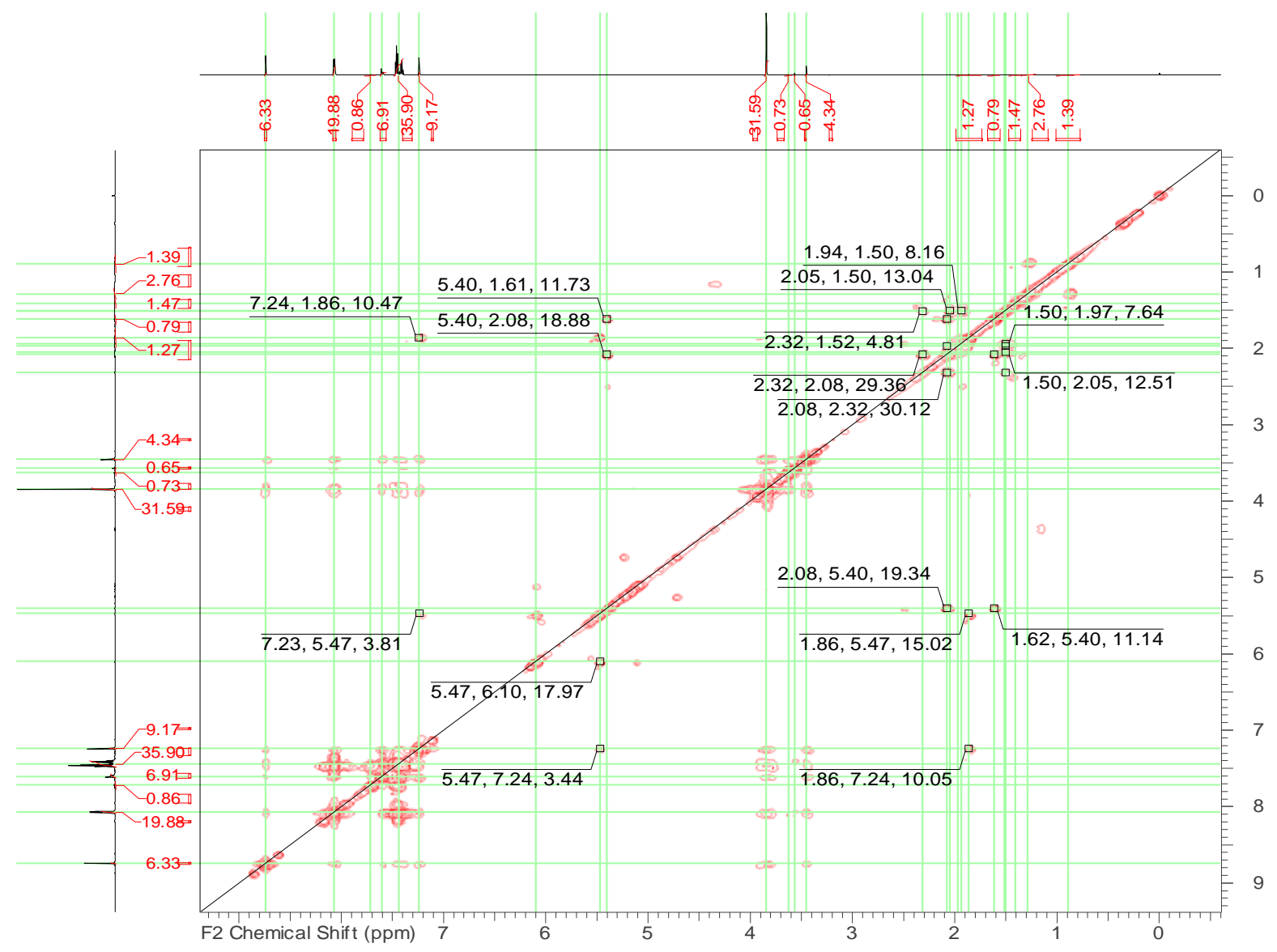

\section{1 and 2D NMR data for elgonene $B$ (3)}

Figure 25: ${ }^{1} \mathrm{H}$ NMR spectrum of elgonene $\mathrm{B}(3)$ in $\mathrm{CDCl}_{3}(500 \mathrm{MHz})$

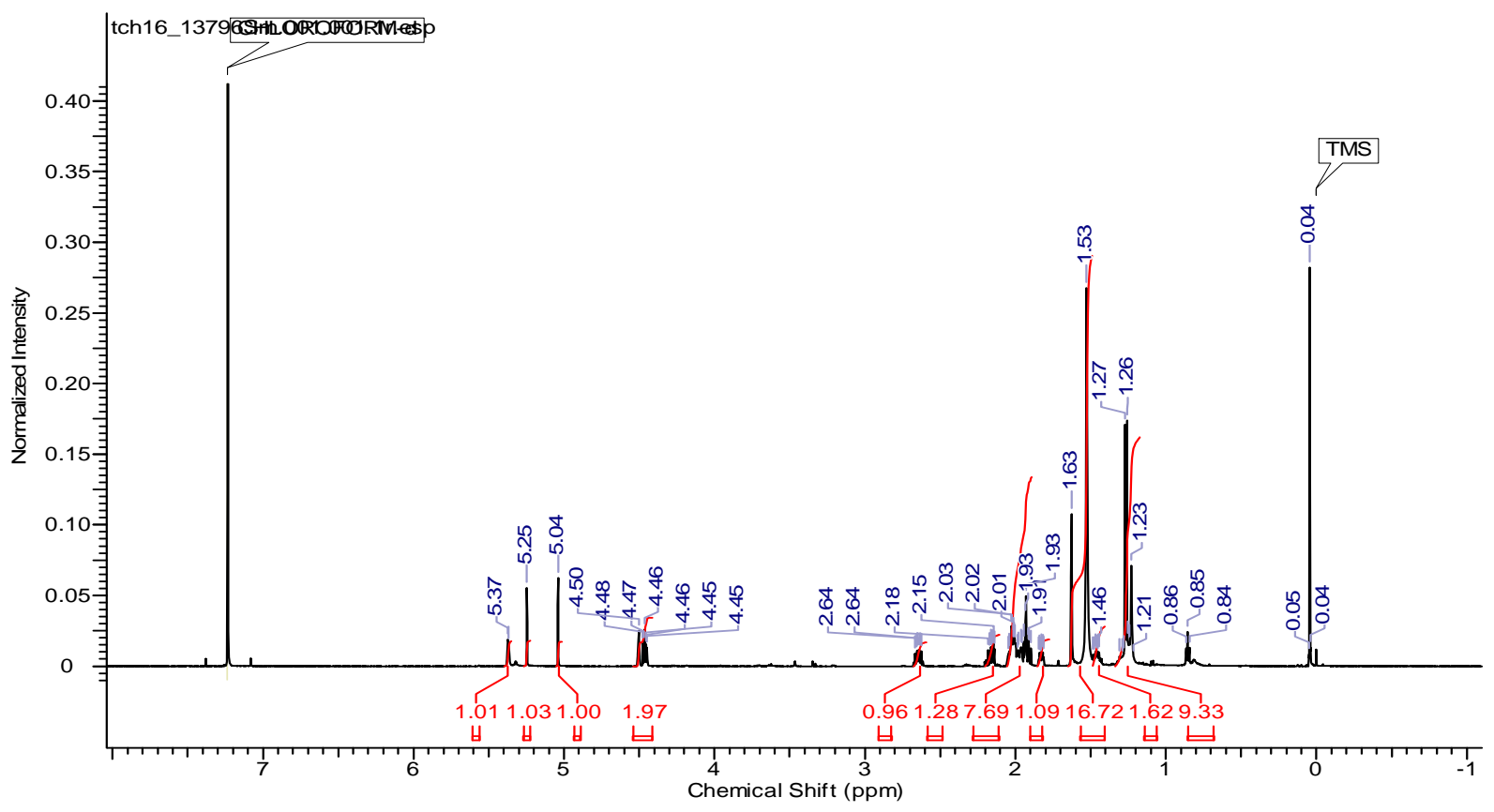


Figure 26: ${ }^{13} \mathrm{C}$ NMR spectrum of elgonene $\mathrm{B}(3)$ in $\mathrm{CDCl}_{3}(125 \mathrm{MHz})$

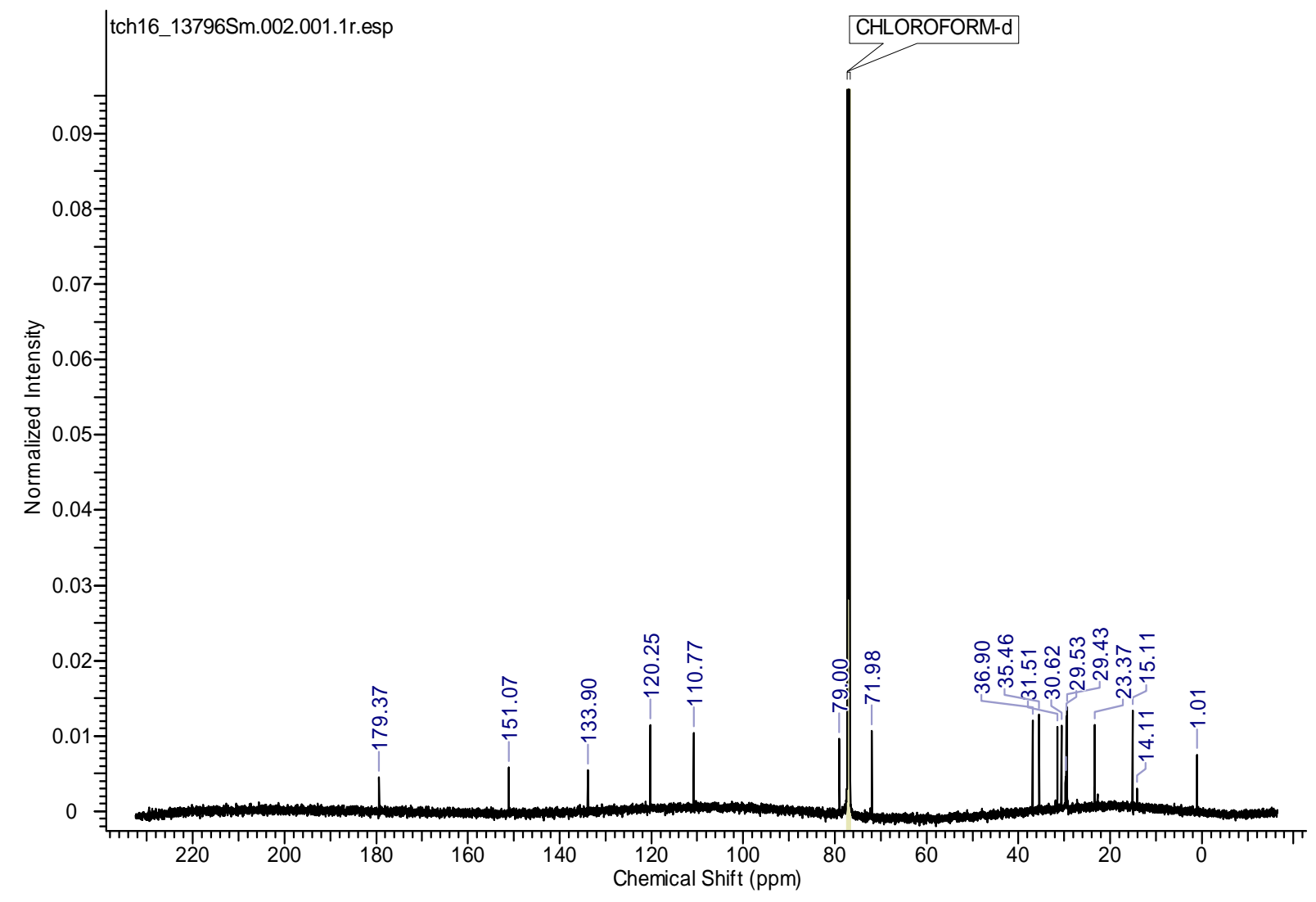

Figure 27: DEPT NMR spectrum of elgonene $\mathrm{B}(3)$ in $\mathrm{CDCl}_{3}(125 \mathrm{MHz})$

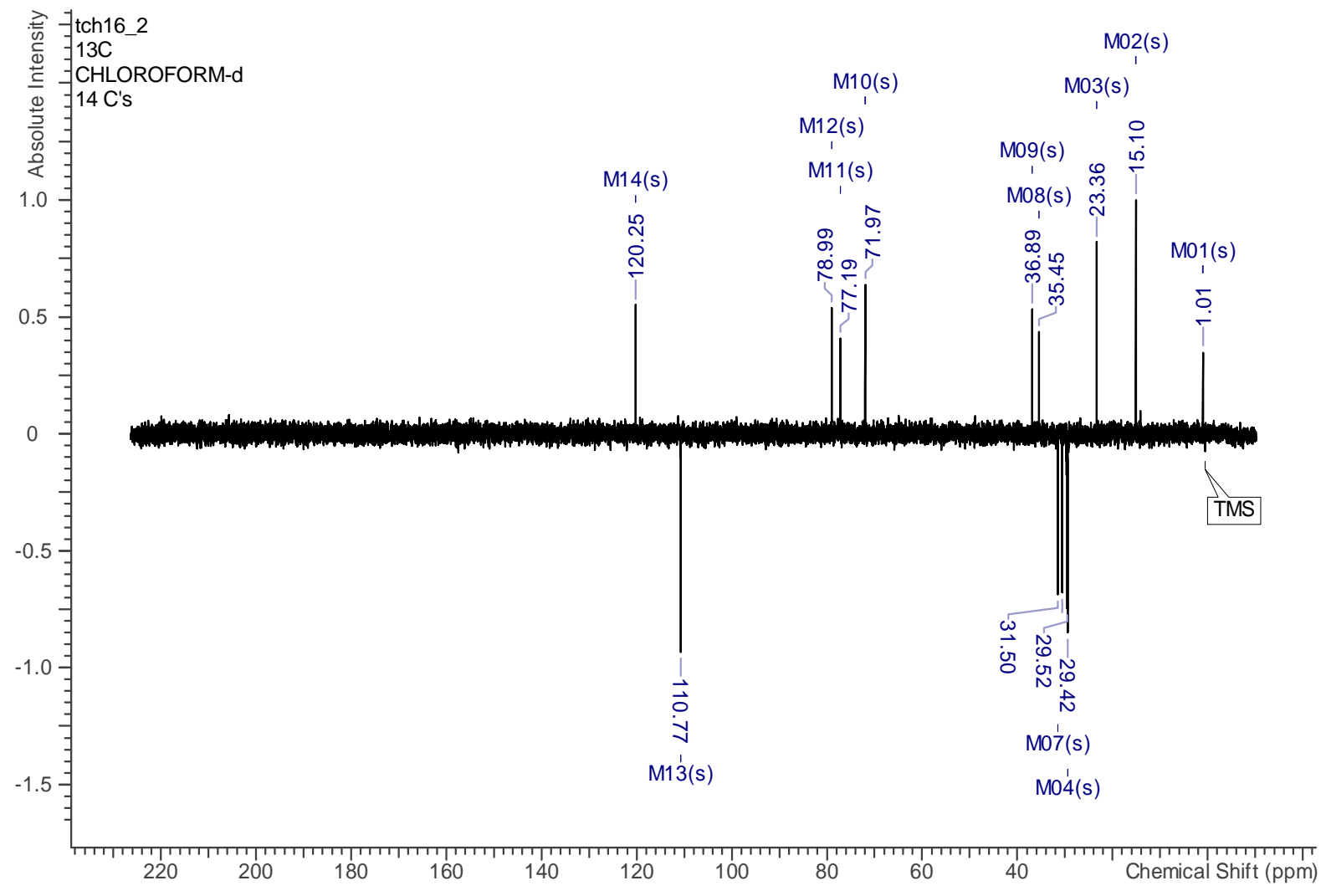


Figure 28: ${ }^{1} \mathrm{H},{ }^{13} \mathrm{C}$ HSQC NMR spectrum of elgonene $\mathrm{B}(3)$ in $\mathrm{CDCl}_{3}(500 \mathrm{MHz}, 125 \mathrm{MHz})$

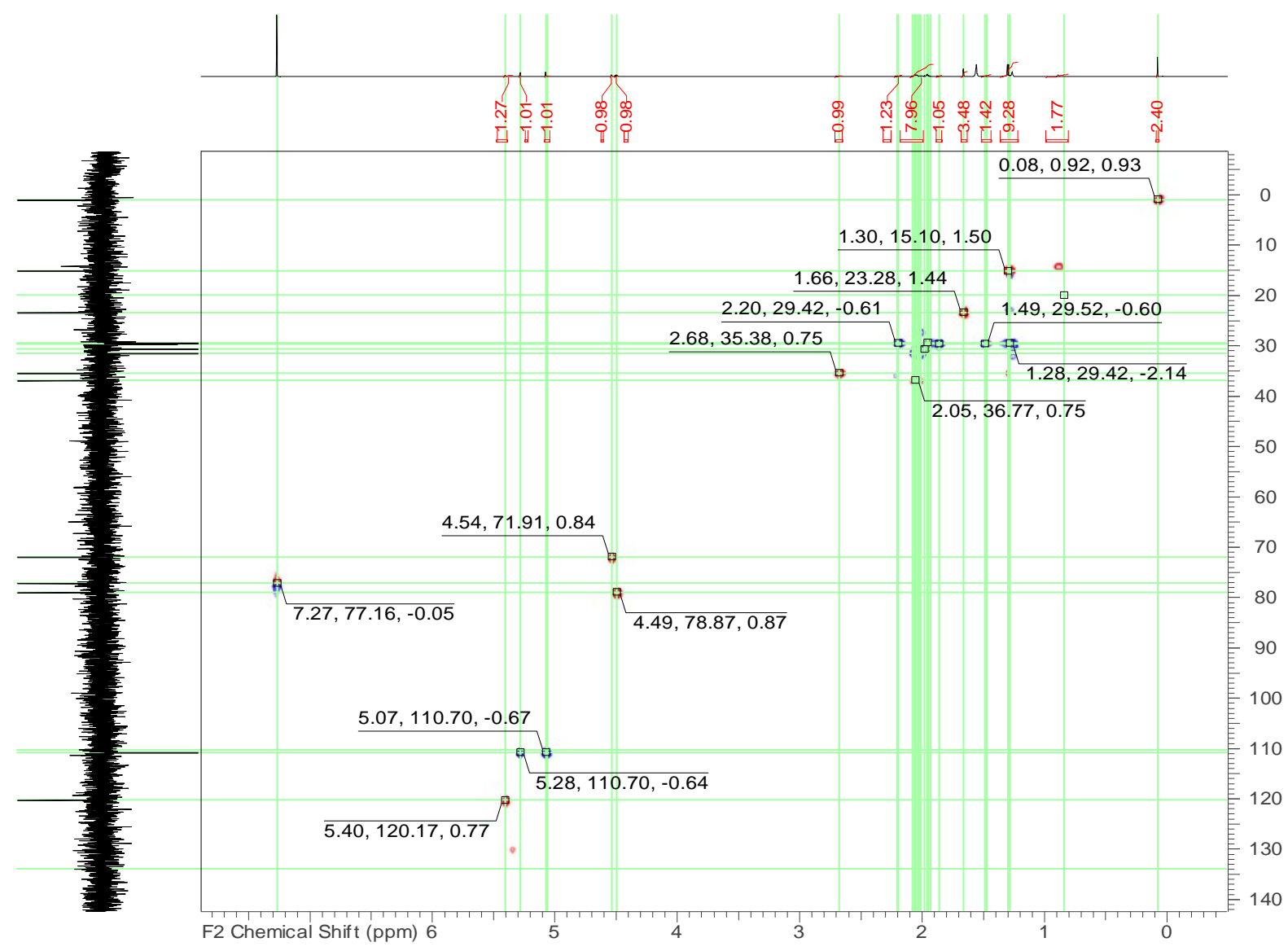

Figure 29: ${ }^{1} \mathrm{H},{ }^{13} \mathrm{C}$ HMBC NMR spectrum of elgonene B (3) in $\mathrm{CDCl}_{3}(500 \mathrm{MHz}, 125 \mathrm{MHz})$ 


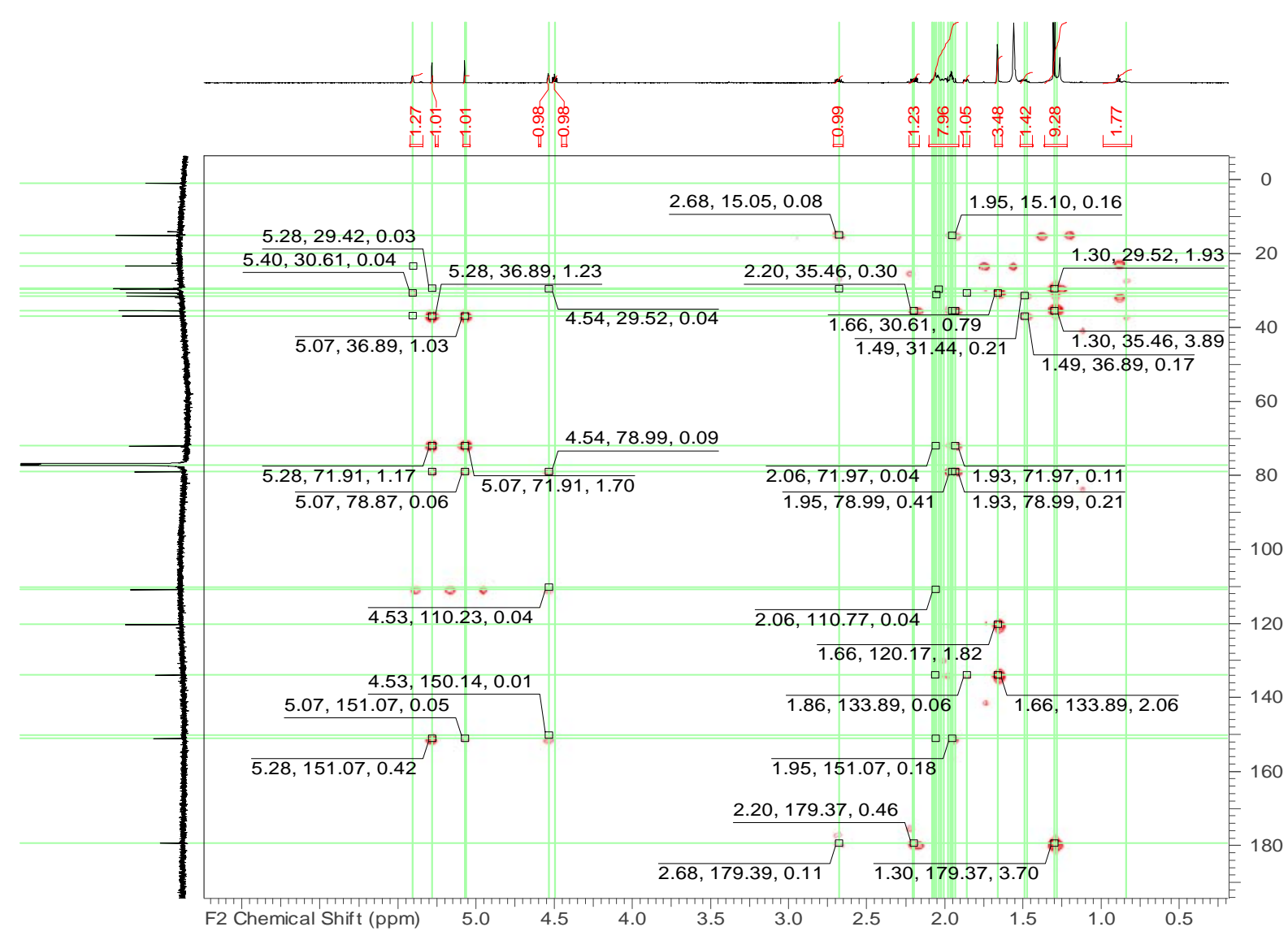

Figure 30: ${ }^{1} \mathrm{H},{ }^{1} \mathrm{H}$ COSY NMR spectrum of elgonene B (3) in $\mathrm{CDCl}_{3}(500 \mathrm{MHz})$

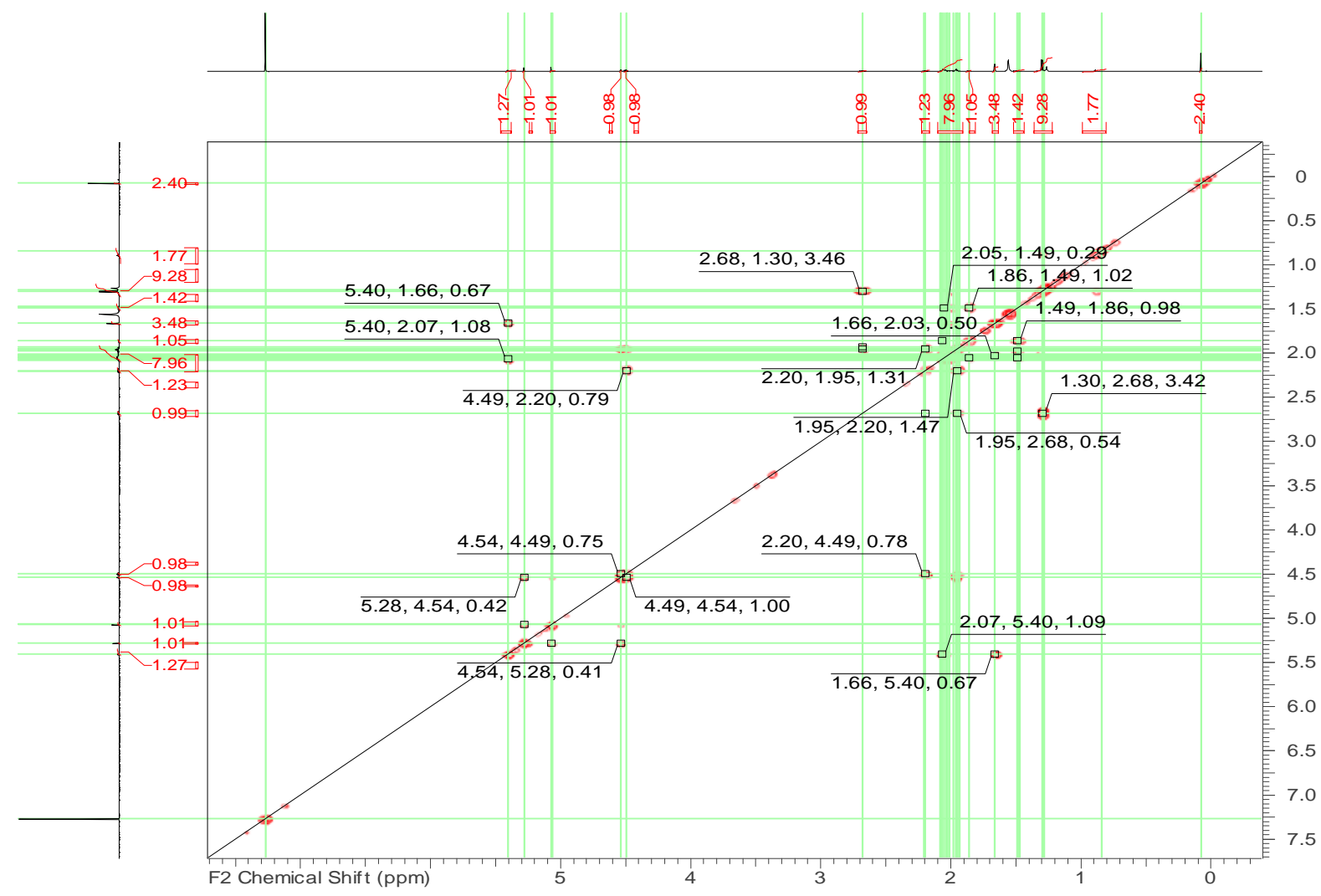


Figure 31: ${ }^{1} \mathrm{H},{ }^{1} \mathrm{H}$ ROESY NMR spectrum of elgonene $\mathrm{B}(3)$ in $\mathrm{CDCl}_{3}(500 \mathrm{MHz})$

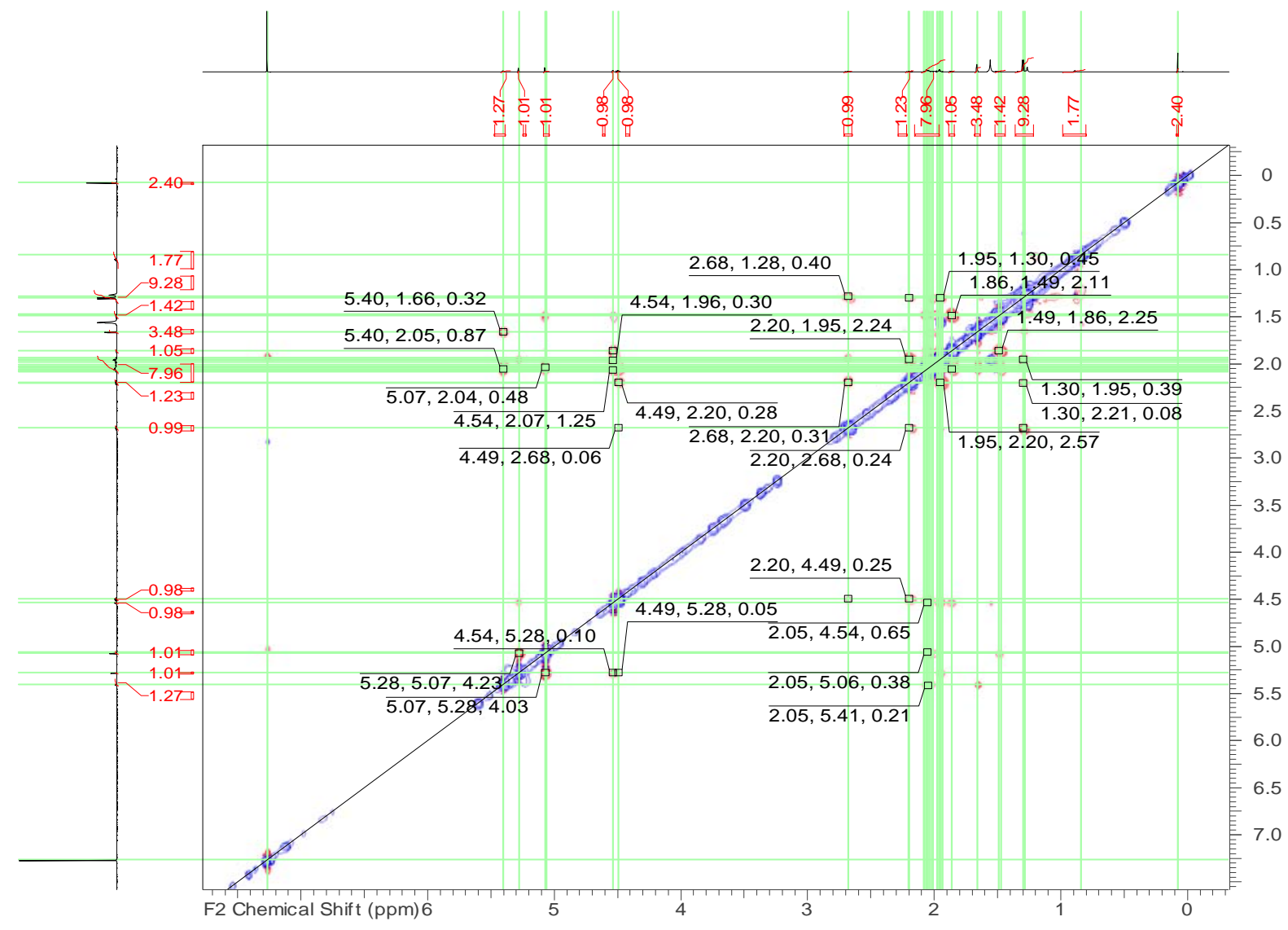


Figure 32: HR-ESIMS spectrum of elgonene B (3)
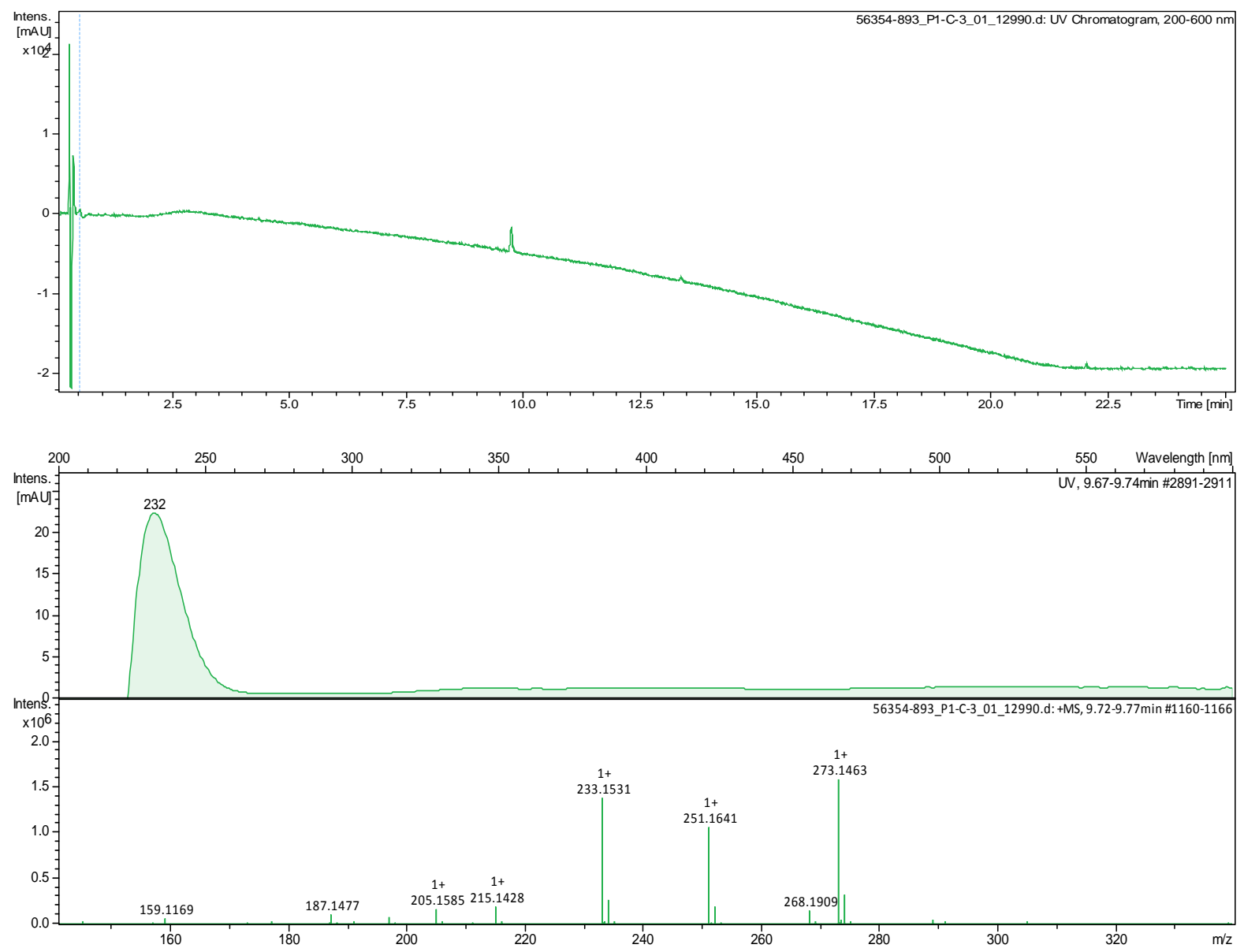

\section{1 and 2D NMR data for elgonene C (4)}

Figure 33: ${ }^{1} \mathrm{H}$ NMR spectrum of elgonene $\mathrm{C}(4)$ in $\mathrm{CDCl}_{3}(500 \mathrm{MHz})$

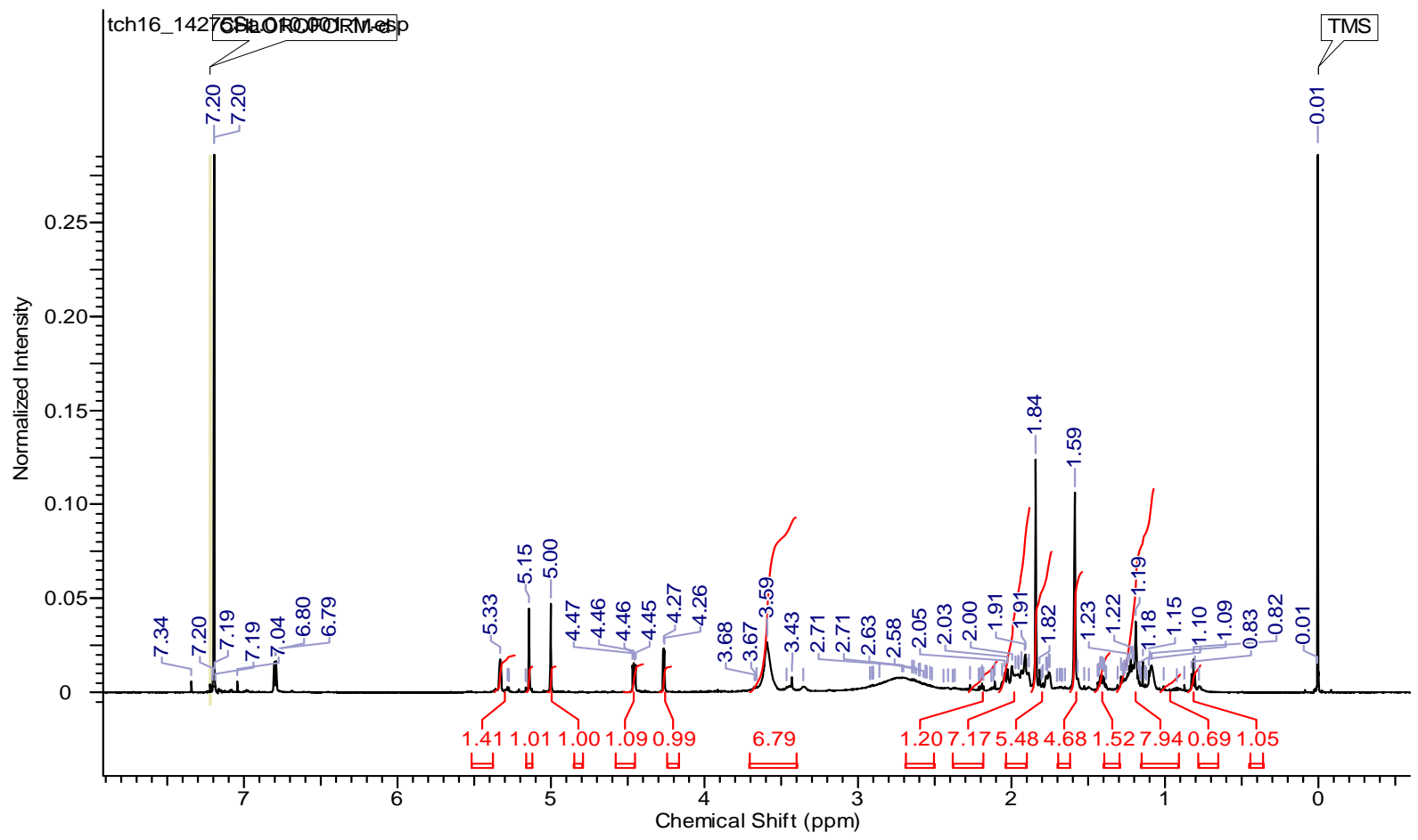


Figure $34:{ }^{13} \mathrm{C}$ NMR spectrum of elgonene $\mathrm{C}(4)$ in $\mathrm{CDCl}_{3}(125 \mathrm{MHz})$

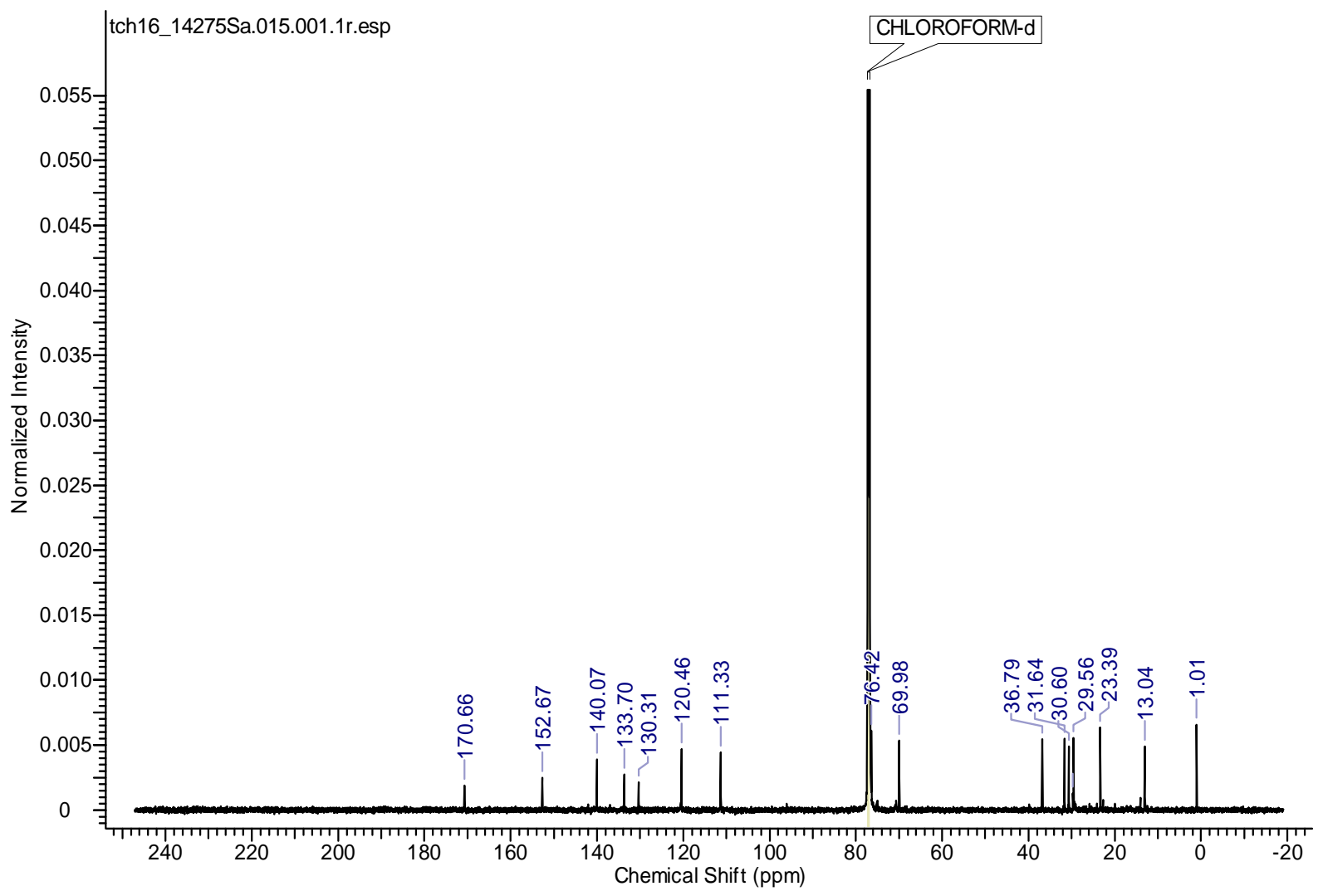

Figure 35: DEPT NMR spectrum of elgonene C (4) in $\mathrm{CDCl}_{3}(125 \mathrm{MHz})$

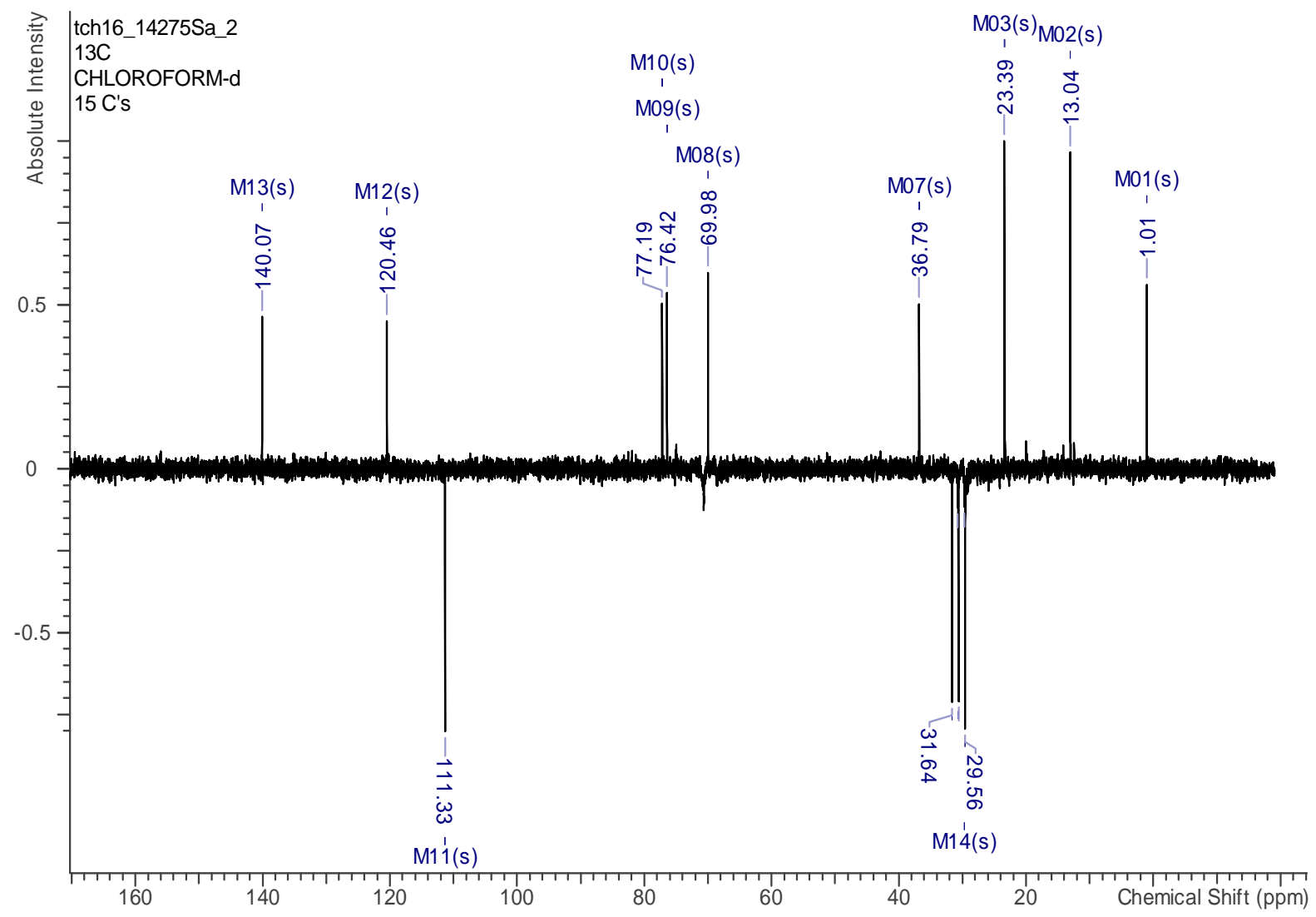


Figure 36: ${ }^{1} \mathrm{H},{ }^{13} \mathrm{C}$ HSQC NMR spectrum of elgonene $\mathrm{C}(4)$ in $\mathrm{CDCl}_{3}(500 \mathrm{MHz}, 125 \mathrm{MHz})$

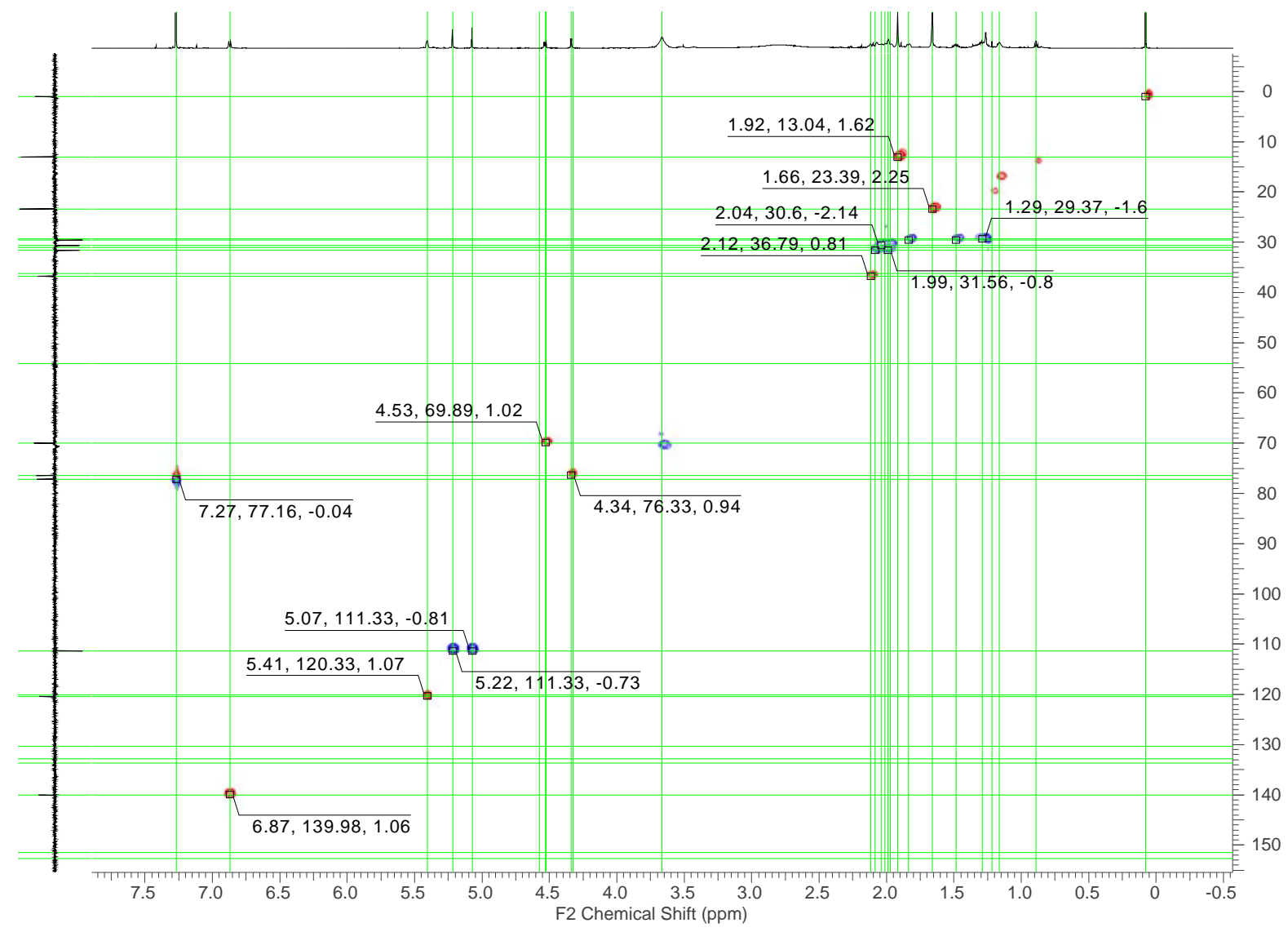

Figure 37: ${ }^{1} \mathrm{H},{ }^{13} \mathrm{C} \mathrm{HMBC}$ NMR spectrum of elgonene $\mathrm{C}(4)$ in $\mathrm{CDCl}_{3}(500 \mathrm{MHz}, 125 \mathrm{MHz})$

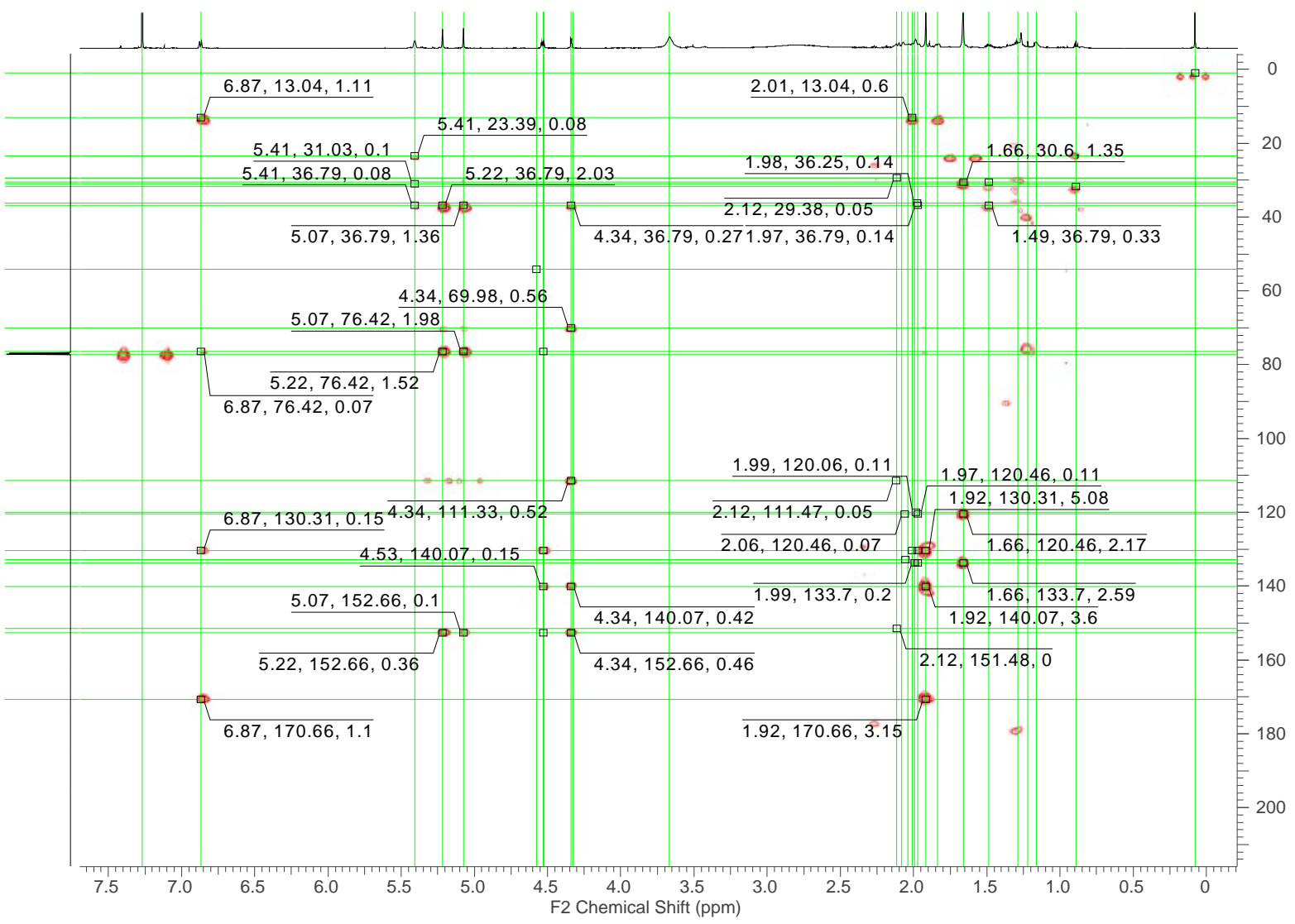


Figure 38: ${ }^{1} \mathrm{H},{ }^{1} \mathrm{H}$ COSY NMR spectrum of elgonene $\mathrm{C}(4)$ in $\mathrm{CDCl}_{3}(500 \mathrm{MHz})$

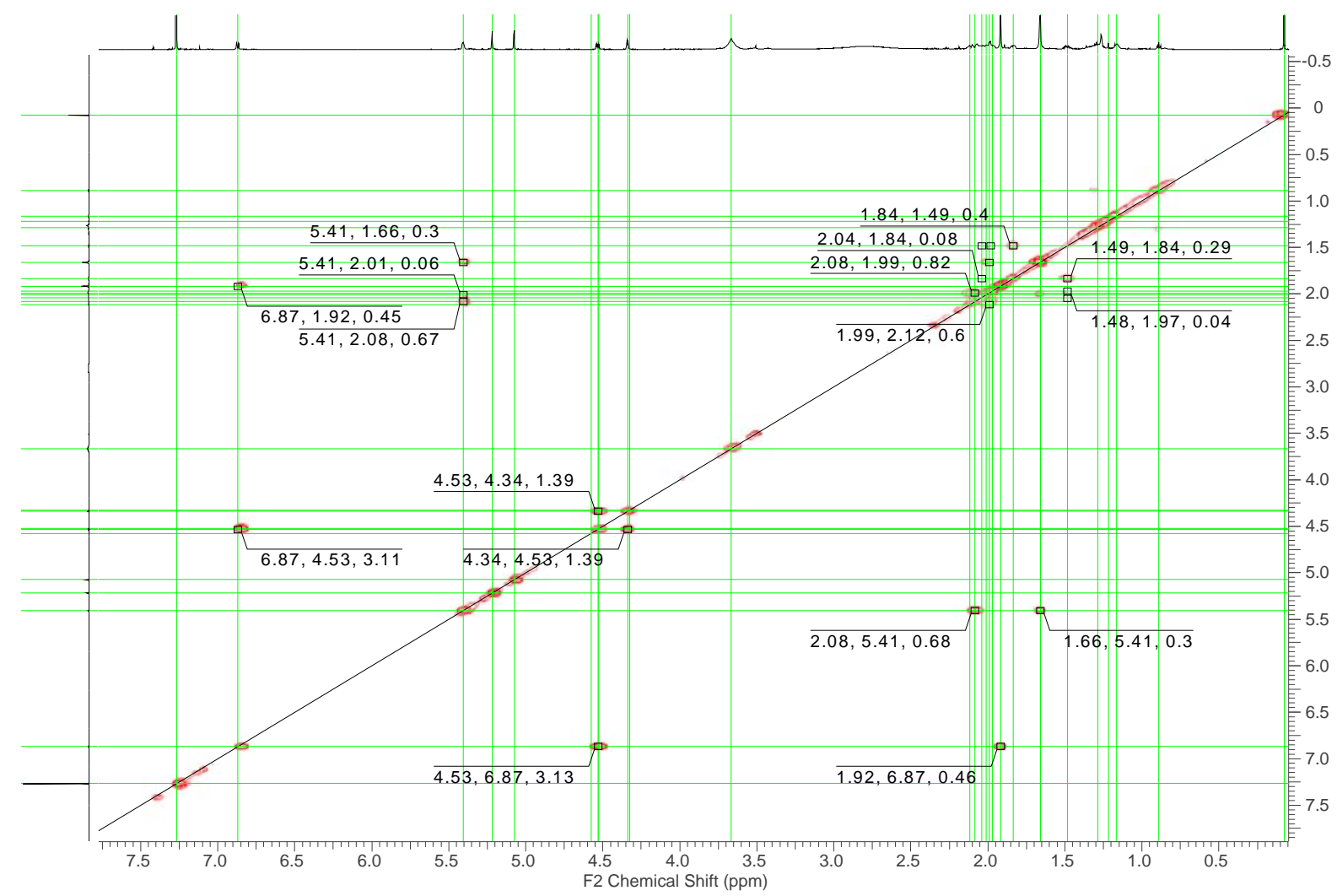

Figure 39: ${ }^{1} \mathrm{H},{ }^{1} \mathrm{H}$ ROESY NMR spectrum of elgonene $\mathrm{C}(4)$ in $\mathrm{CDCl}_{3}(500 \mathrm{MHz})$

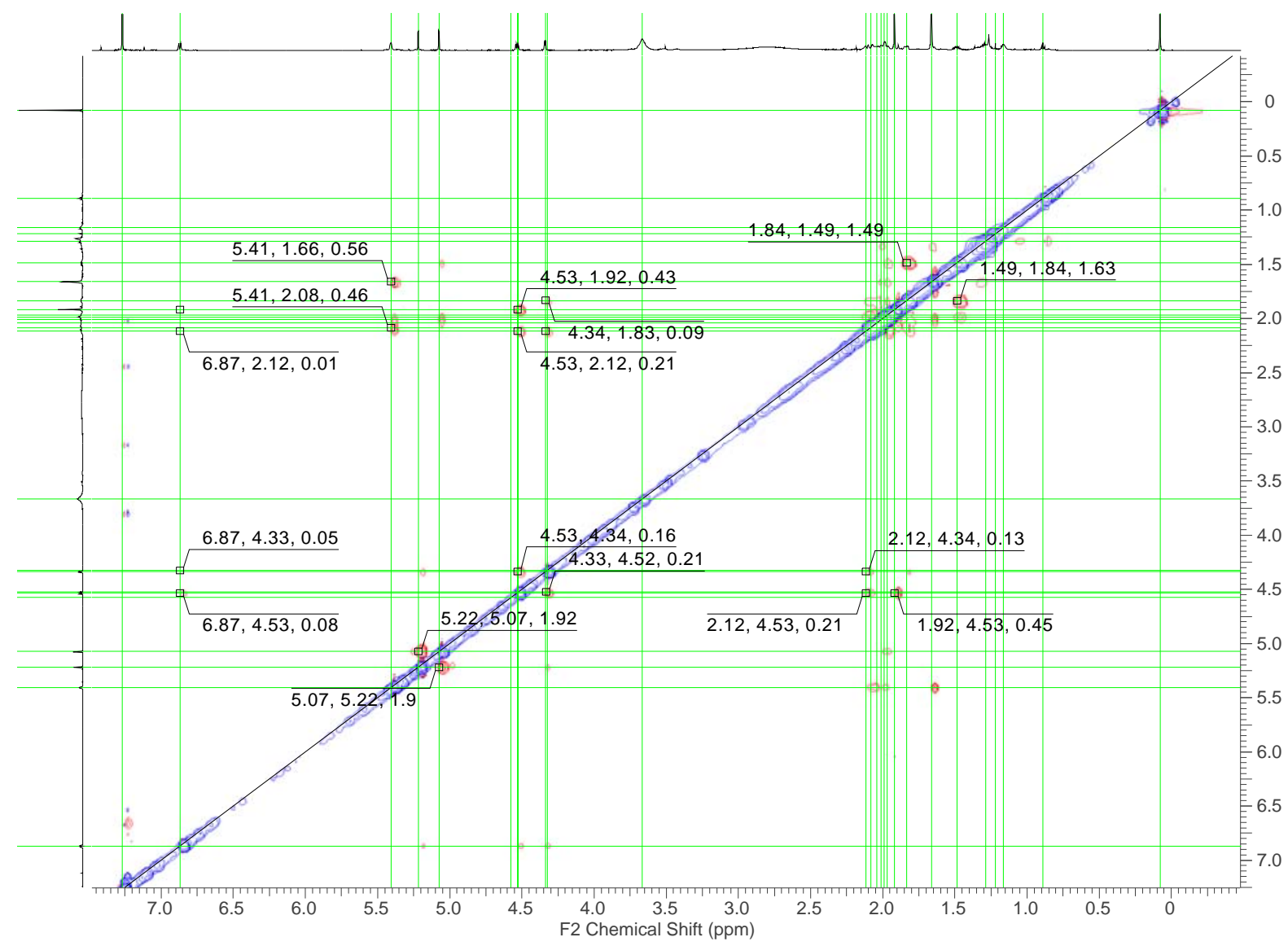


Figure 40: HR-ESIMS spectrum of elgonene C (4)
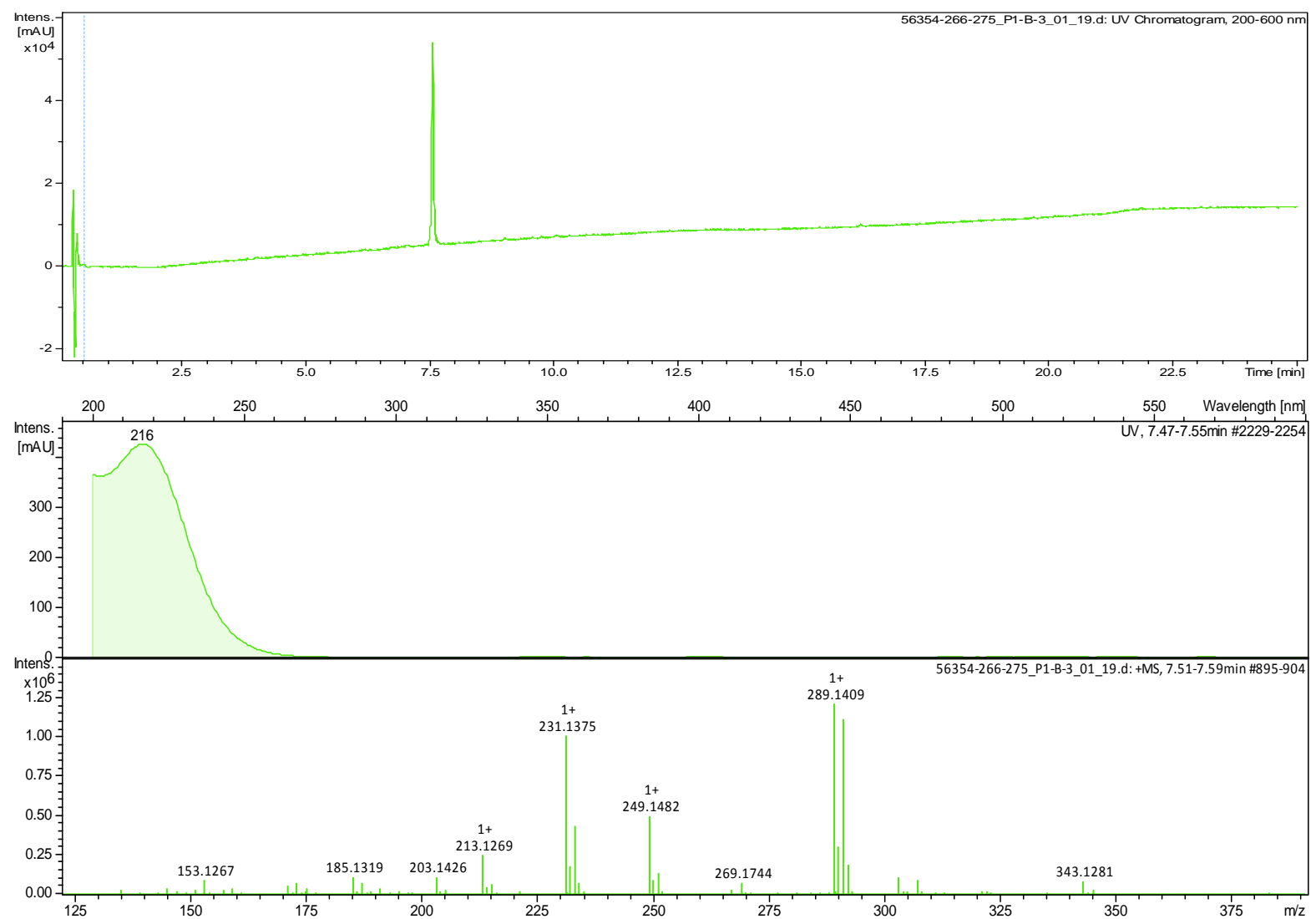

\section{1 and 2D NMR data for elgonene $D$ (5)}

Figure 41: ${ }^{1} \mathrm{H}$ NMR spectrum of elgonene D (5) in acetone- $\mathrm{d}_{6}(500 \mathrm{MHz})$

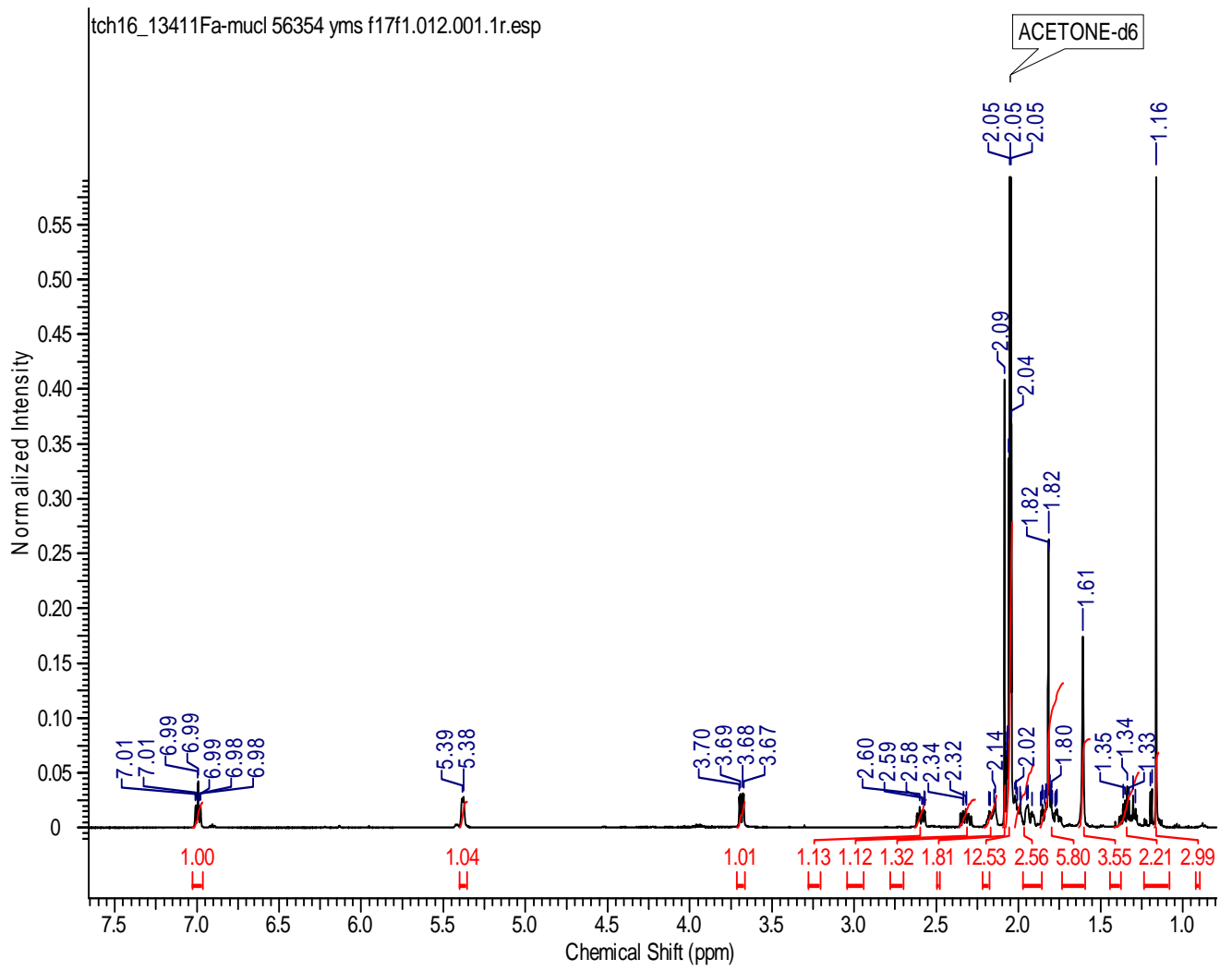


Figure $42:{ }^{13} \mathrm{C}$ NMR spectrum of elgonene $\mathrm{D}(5)$ in acetone- $\mathrm{d}_{6}(125 \mathrm{MHz})$

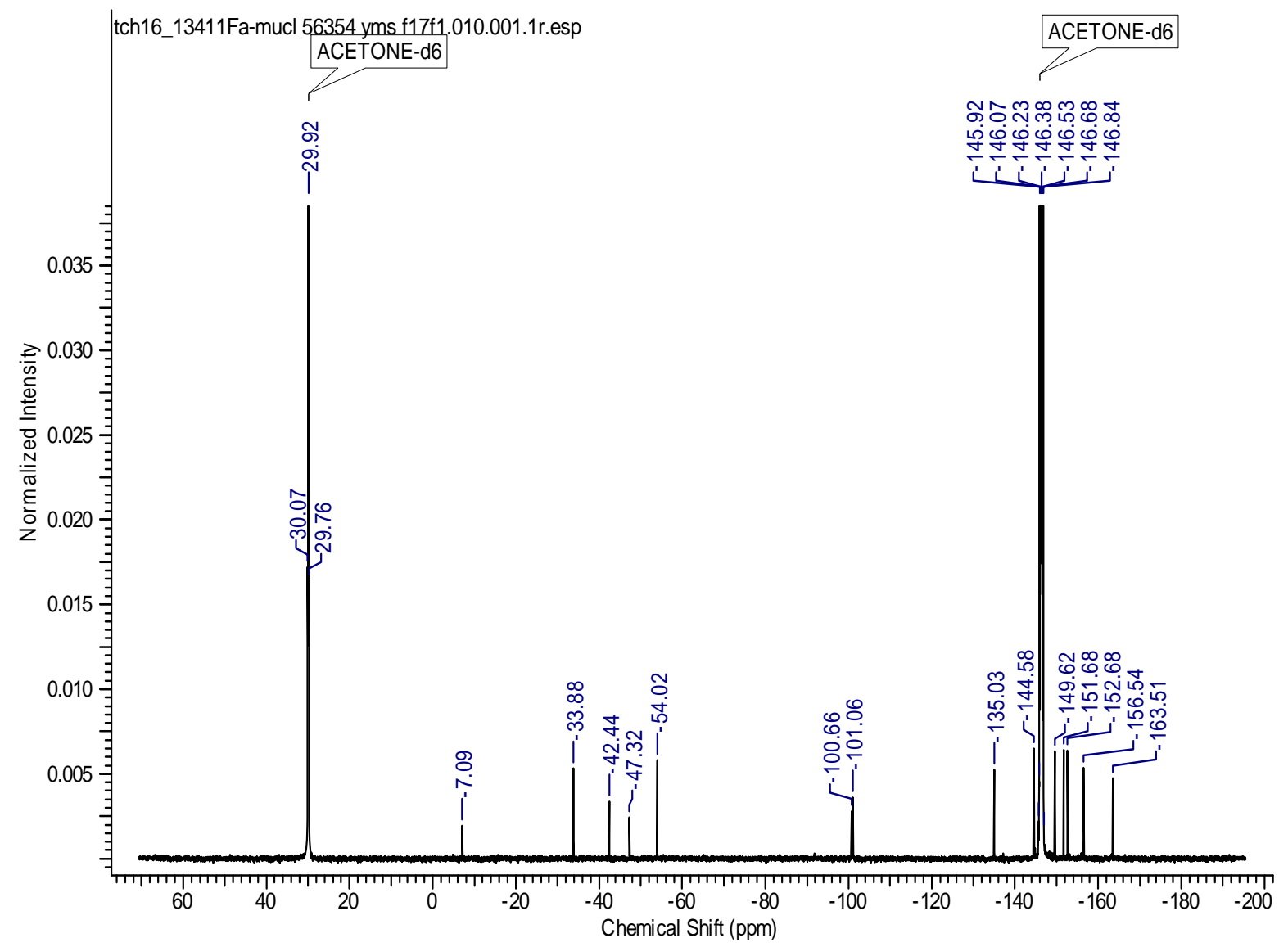

Figure 43: DEPT NMR spectrum of elgonene D (5) in acetone- $\mathrm{d}_{6}(125 \mathrm{MHz})$

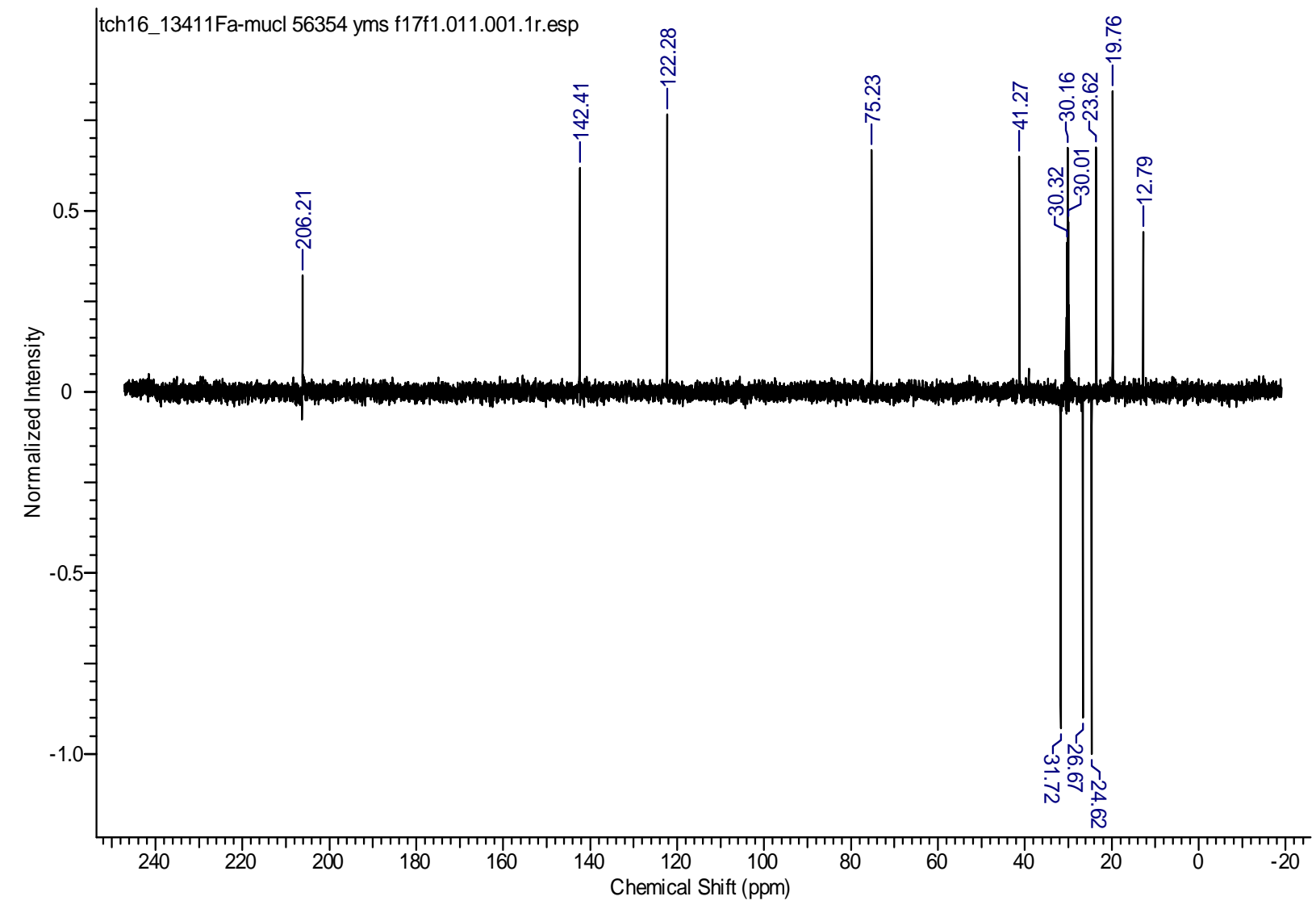


Figure 44: ${ }^{1} \mathrm{H},{ }^{13} \mathrm{C}$ HSQC NMR spectrum of elgonene D (5) in acetone- $\mathrm{d}_{6}(500 \mathrm{MHz}, 125$ $\mathrm{MHz})$

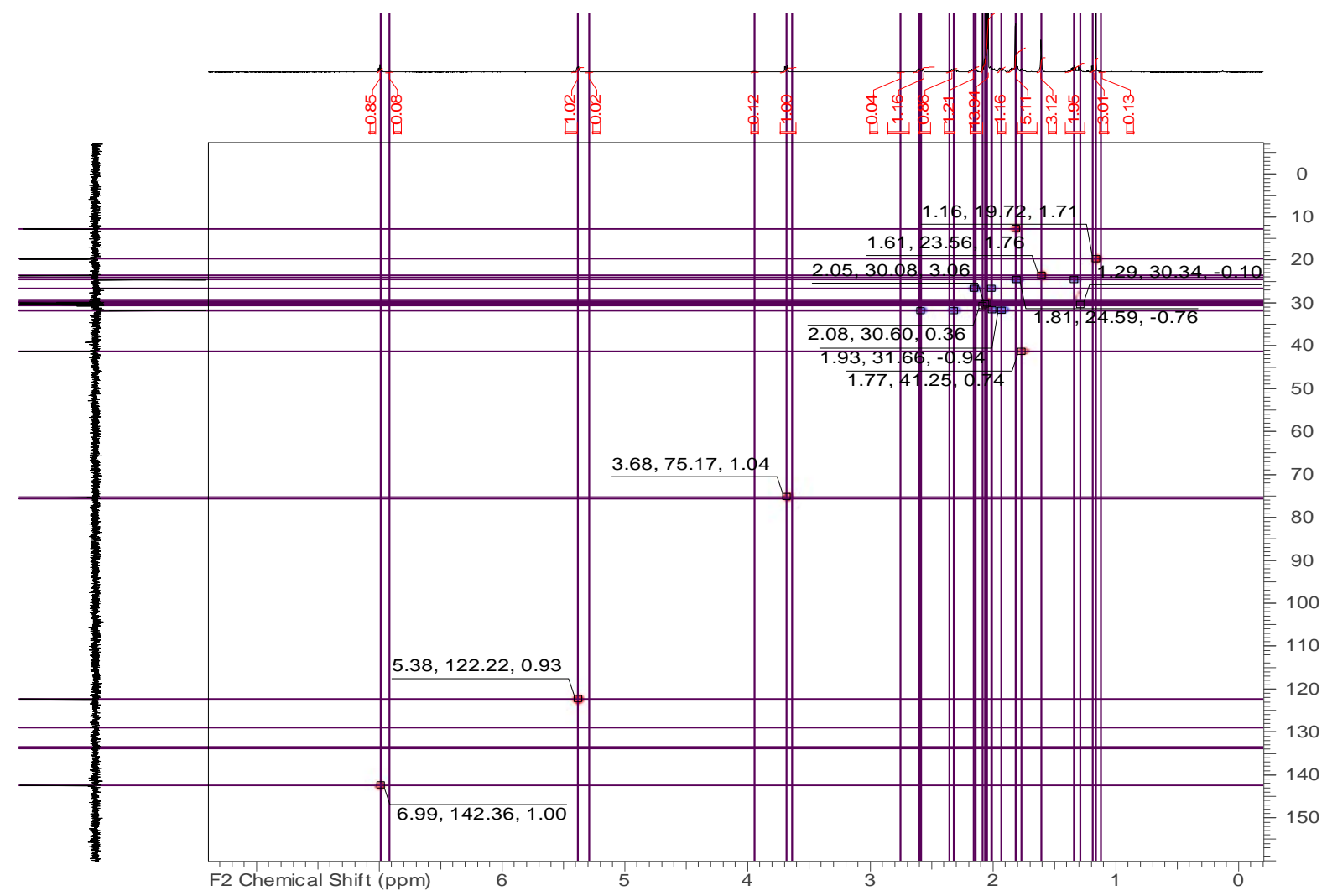

Figure $45:{ }^{1} \mathrm{H},{ }^{13} \mathrm{C}$ HMBC NMR spectrum of elgonene D (5) in acetone- $\mathrm{d}_{6}(500 \mathrm{MHz}, 125$ $\mathrm{MHz})$

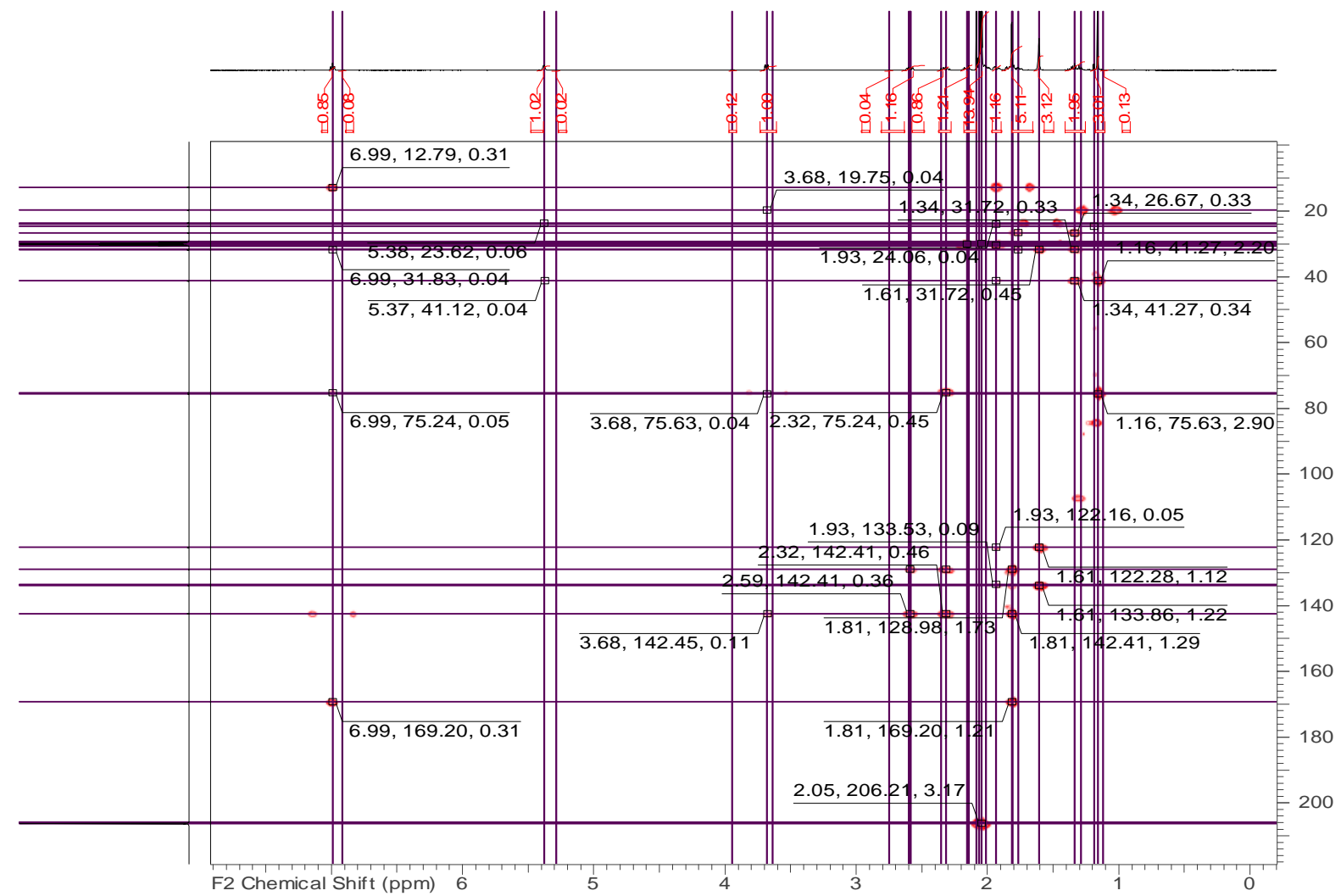


Figure 46: ${ }^{1} \mathrm{H},{ }^{1} \mathrm{H}$ COSY NMR spectrum of elgonene D (5) in acetone- $\mathrm{d}_{6}(500 \mathrm{MHz})$

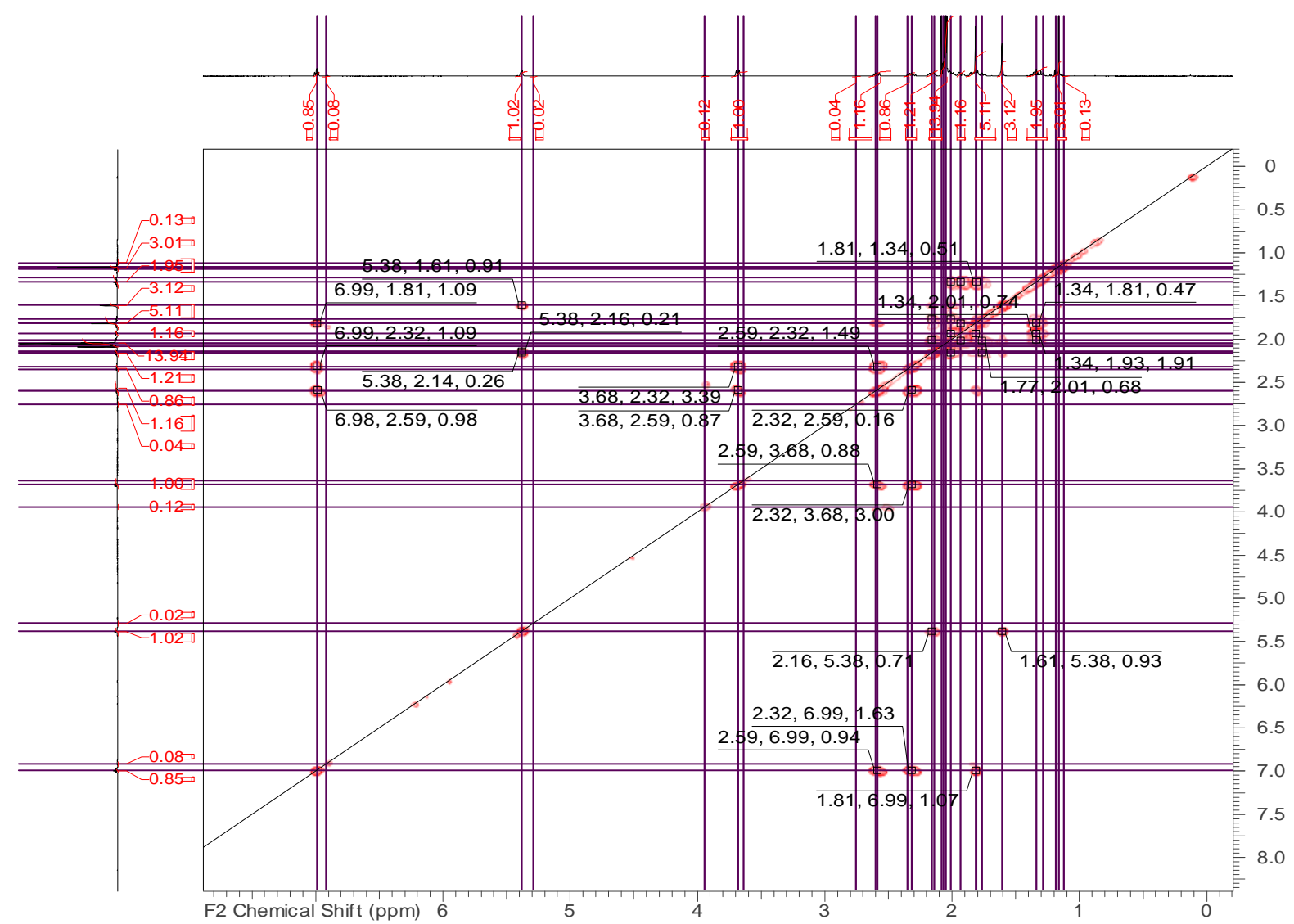

Figure 47: ${ }^{1} \mathrm{H},{ }^{1} \mathrm{H}$ ROESY NMR spectrum of elgonene D (5) in acetone- $\mathrm{d}_{6}(500 \mathrm{MHz})$

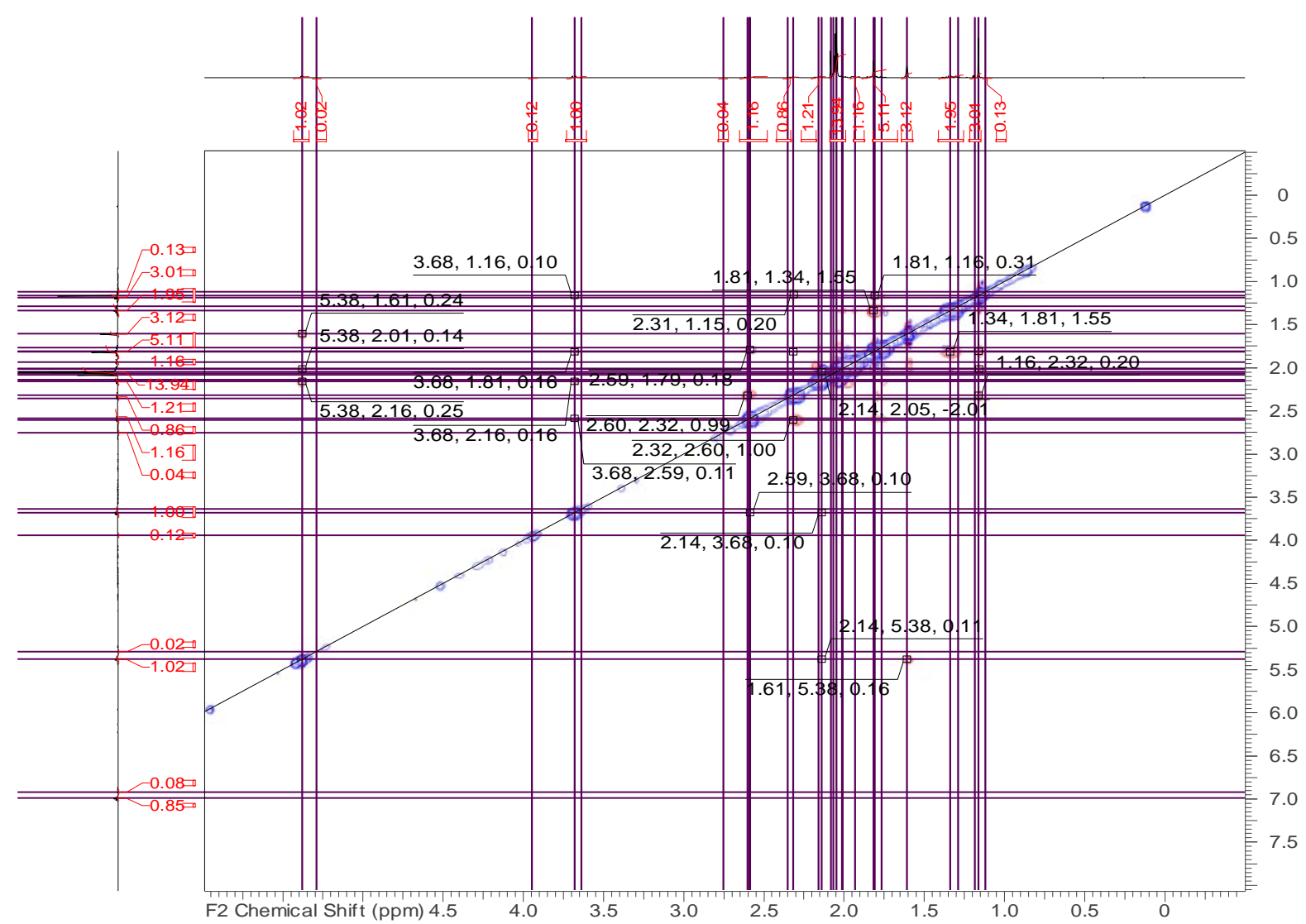


Figure 48: HR-ESIMS spectrum of elgonene D (5)
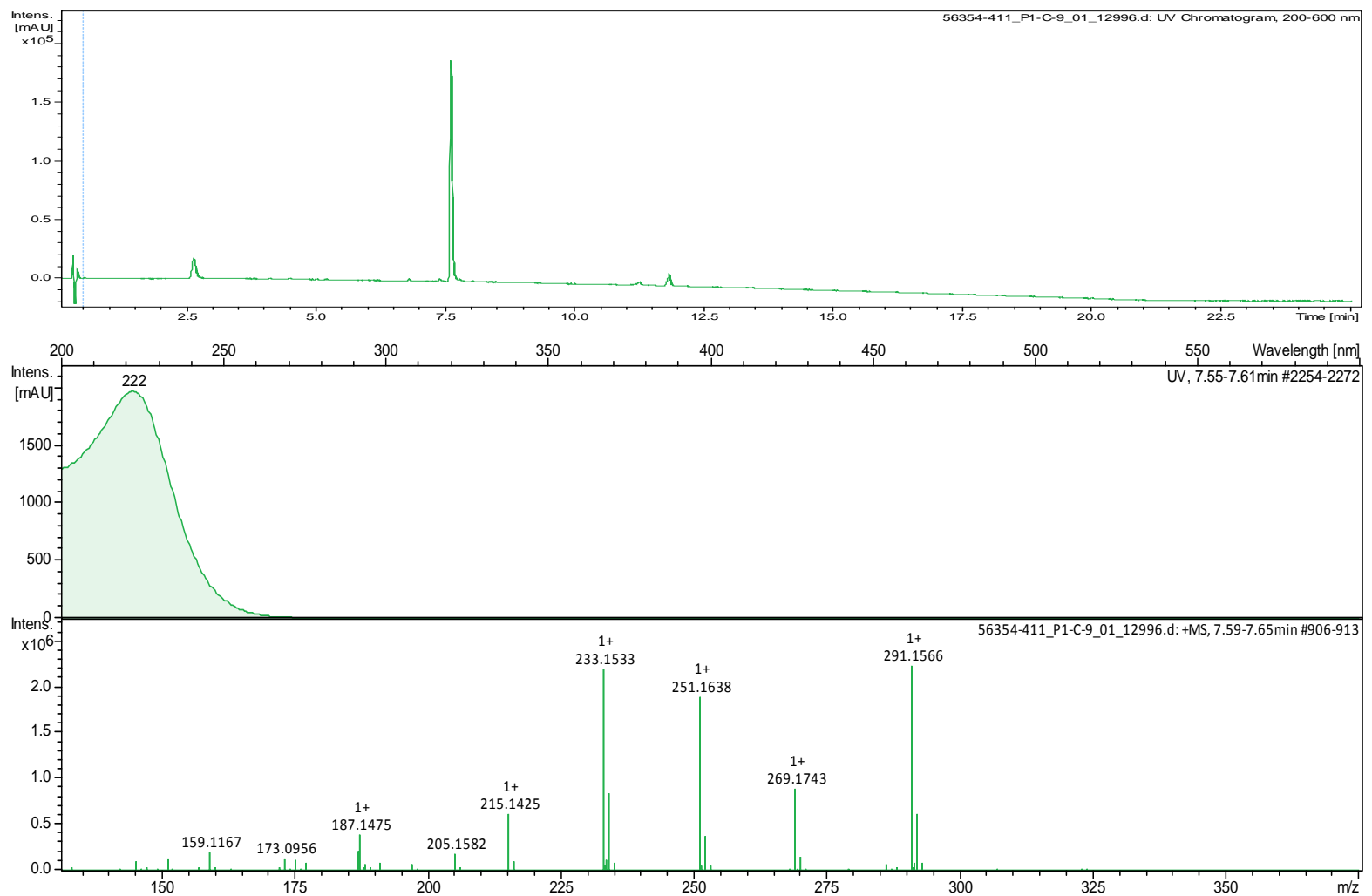

Figure 49: ${ }^{1} \mathrm{HNMR}$ spectrum of elgonene D (5) (R)- MTPA ester in pyridine $\mathrm{d}_{5}(700 \mathrm{MHz})$

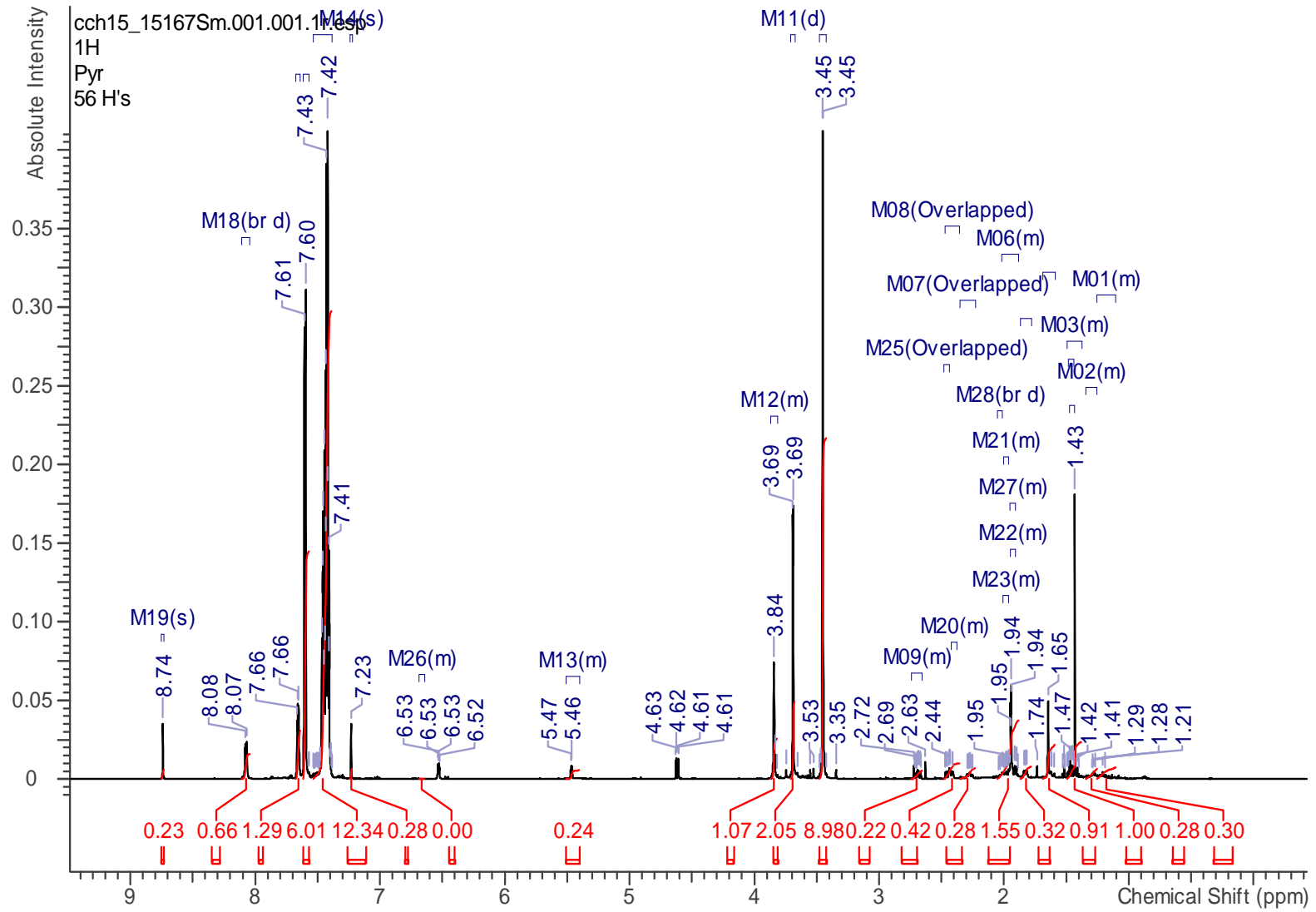


Figure 50: ${ }^{1} \mathrm{H},{ }^{1} \mathrm{H}$ COSY NMR spectrum of elgonene D (5) (R)- MTPA ester in pyridine $\mathrm{d}_{5}$ (700 MHz)

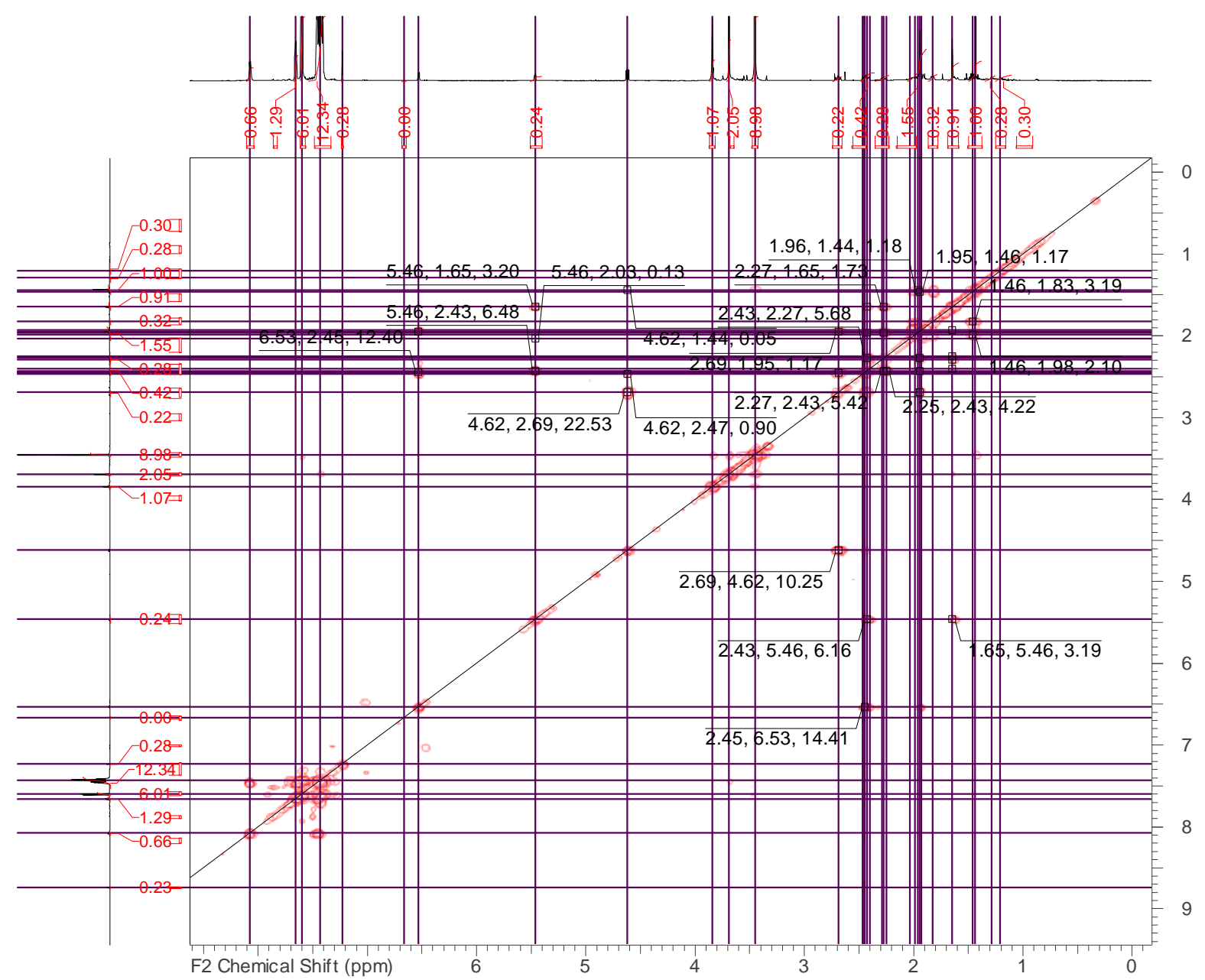

Figure 51: ${ }^{1} \mathrm{HNMR}$ spectrum of elgonene D (5) (S)- MTPA ester in pyridine $\mathrm{d}_{5}(700 \mathrm{MHz})$

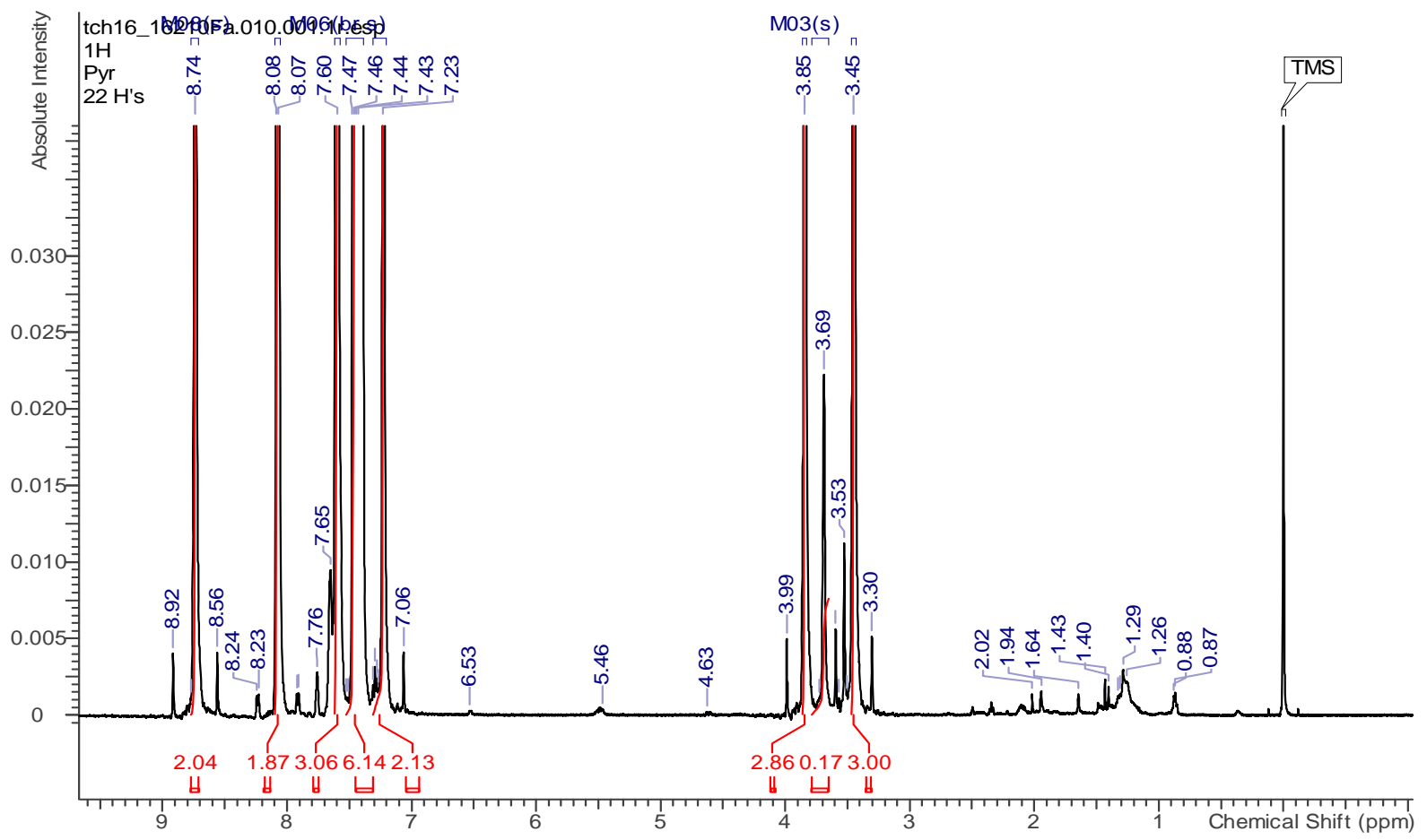


Figure 52: ${ }^{1} \mathrm{H},{ }^{1} \mathrm{H}$ COSY NMR spectrum of elgonene D (5) (S)- MTPA ester in pyridine $\mathrm{d}_{5}$ (700 MHz)

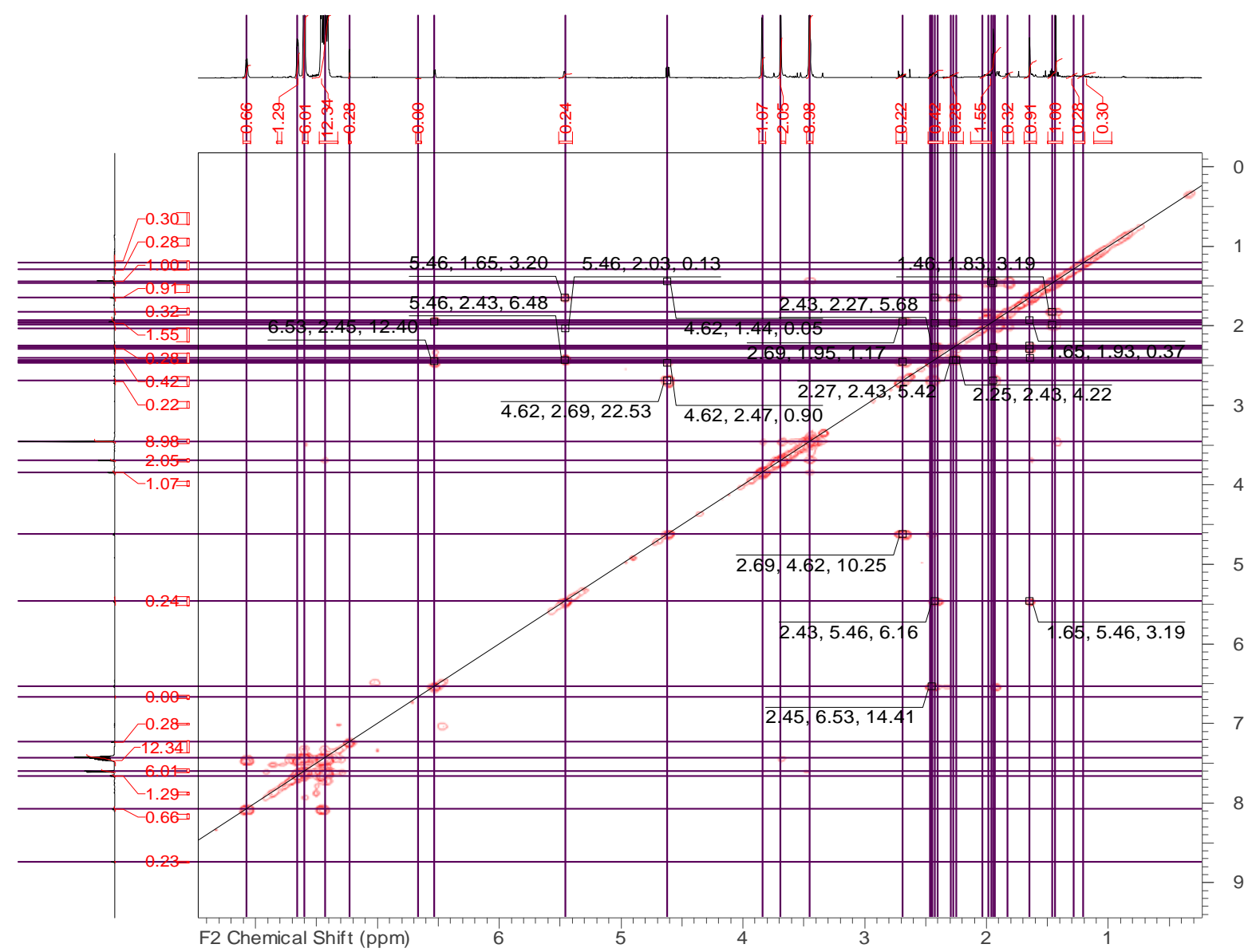

\section{1 and 2D NMR data for elgonene $E$ (6)}

Figure 53: ${ }^{1} \mathrm{HNMR}$ spectrum of elgonene $\mathrm{E}(6)$ in methanol $\mathrm{d}_{4}(700 \mathrm{MHz})$

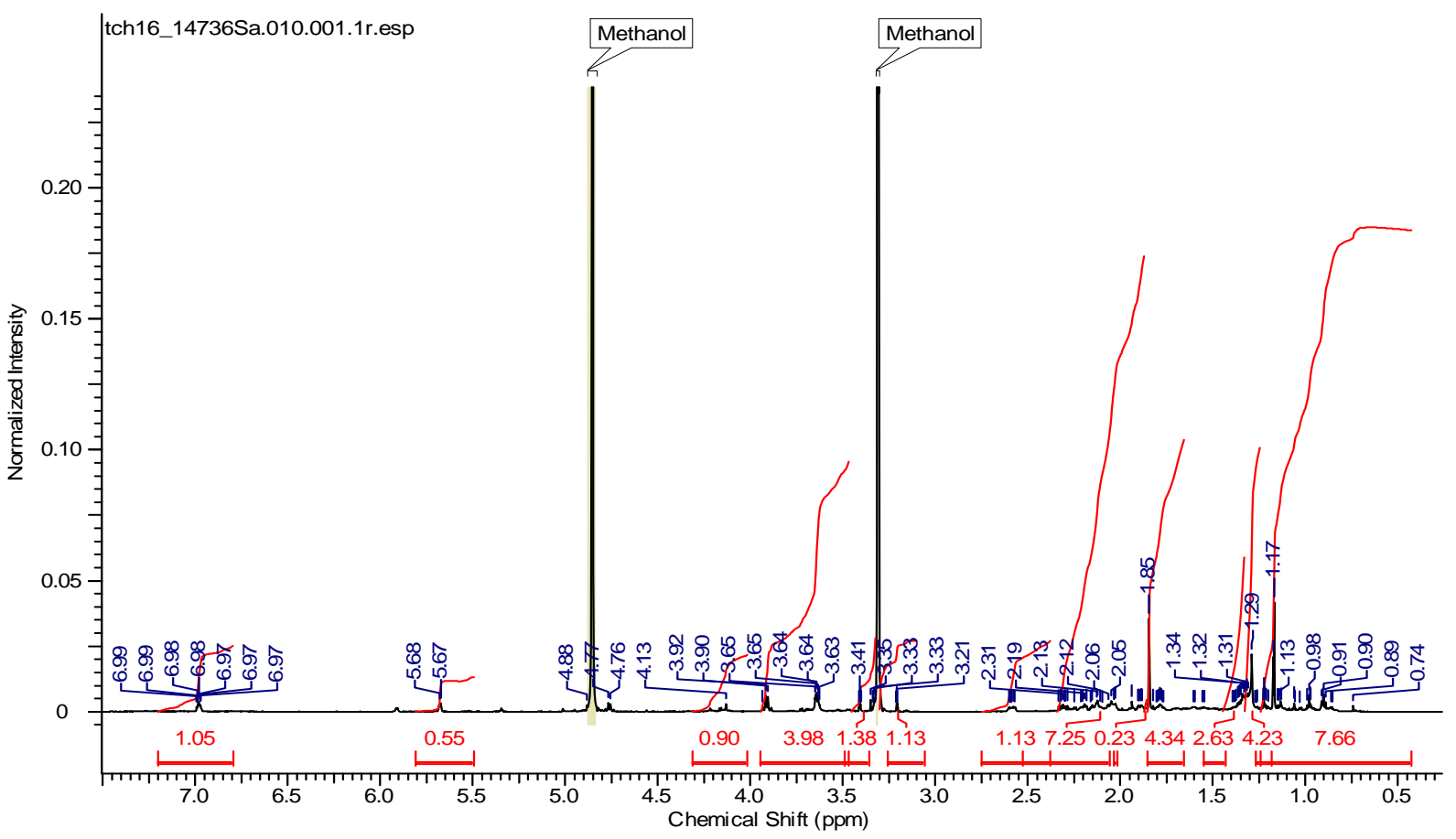


Figure 54: ${ }^{13} \mathrm{C}$ NMR spectrum of elgonene $\mathrm{E}(\mathbf{6})$ in methanol $\mathrm{d}_{4}(175 \mathrm{MHz})$

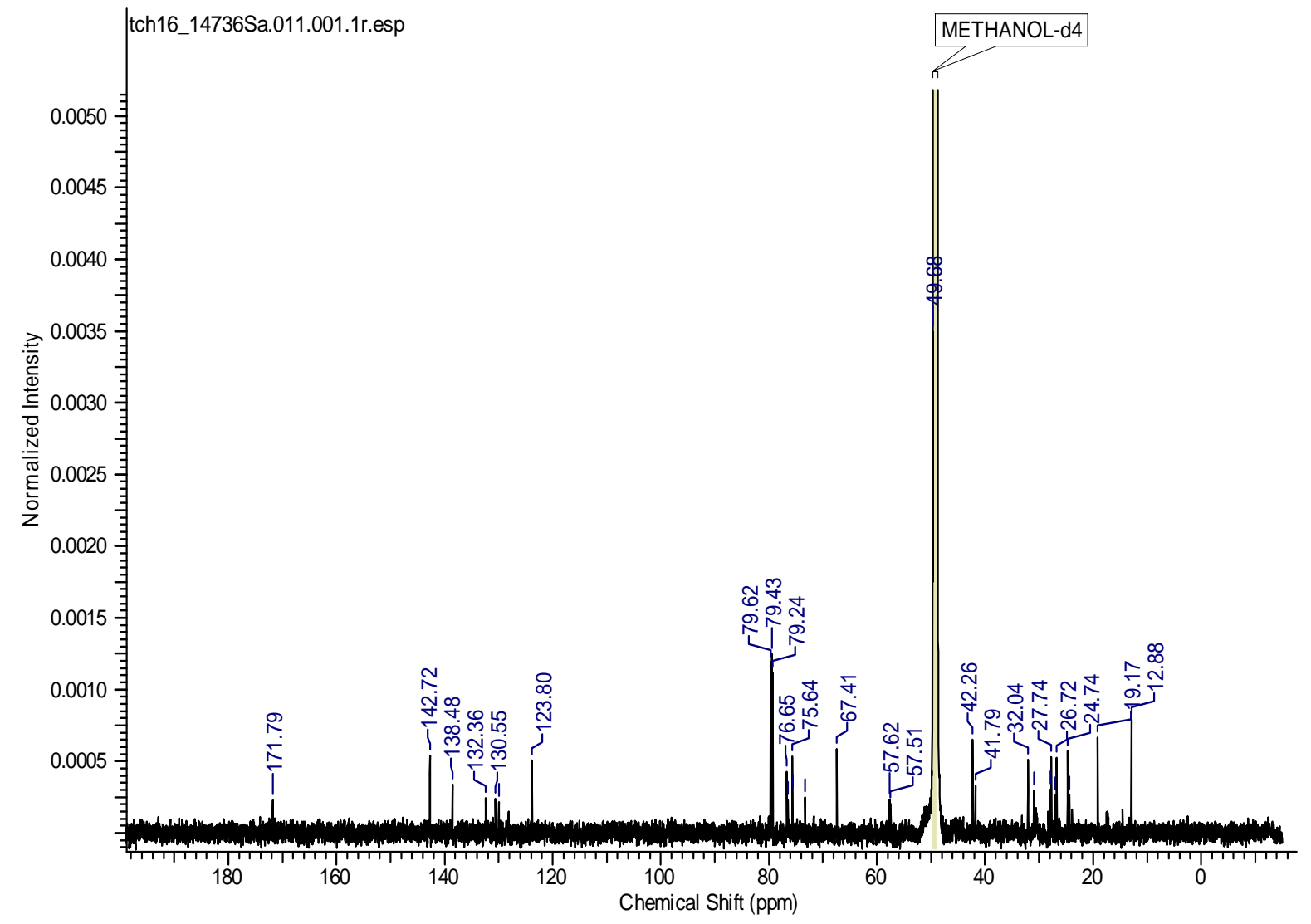

Figure 55: DEPT NMR spectrum of elgonene E (6) in methanol $\mathrm{d}_{4}(175 \mathrm{MHz})$

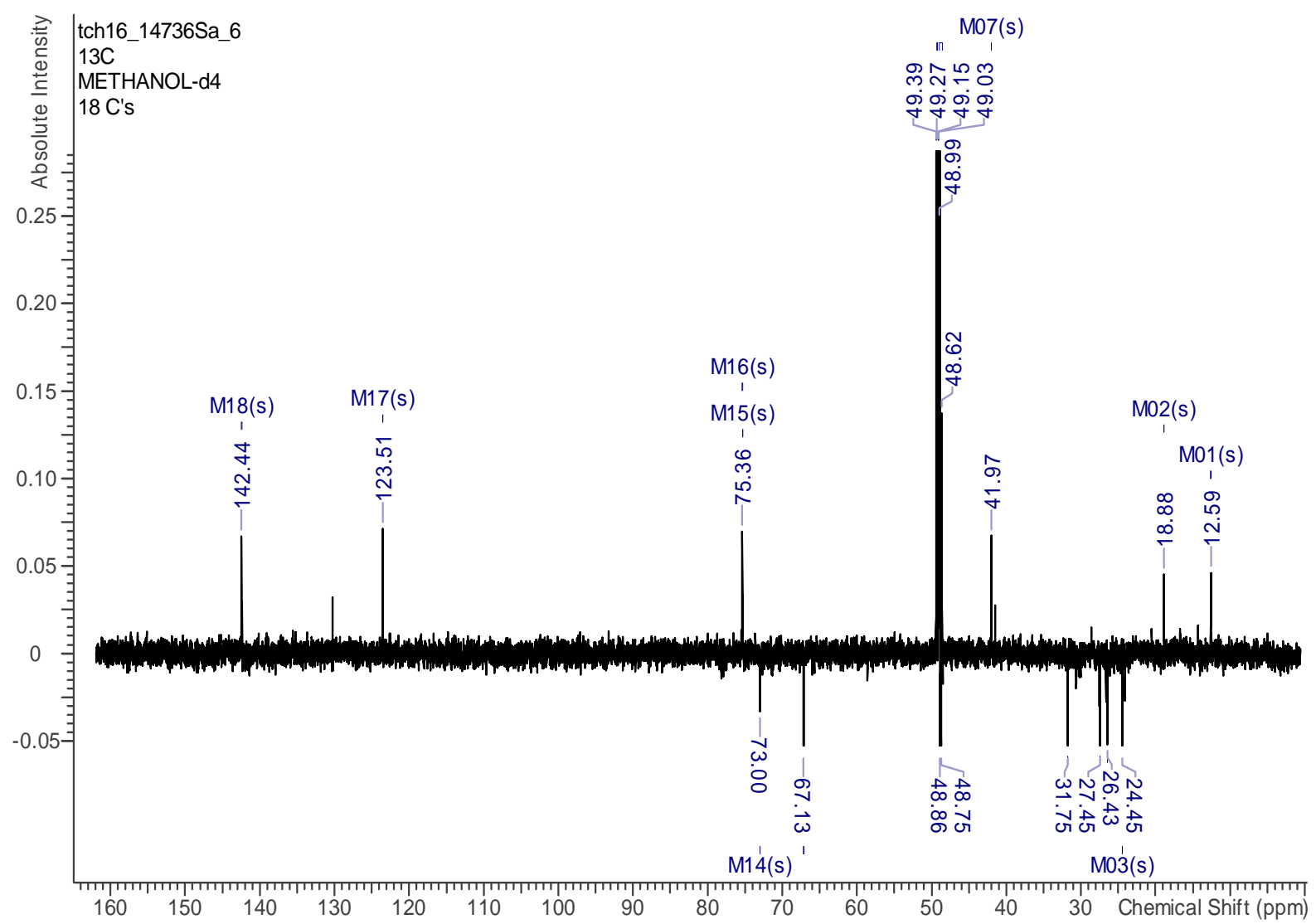


Figure 56: ${ }^{1} \mathrm{H},{ }^{13} \mathrm{C}$ HSQC NMR spectrum of elgonene $\mathrm{E}(6)$ in methanol $\mathrm{d}_{4}(700 \mathrm{MHz}, 125$ $\mathrm{MHz})$

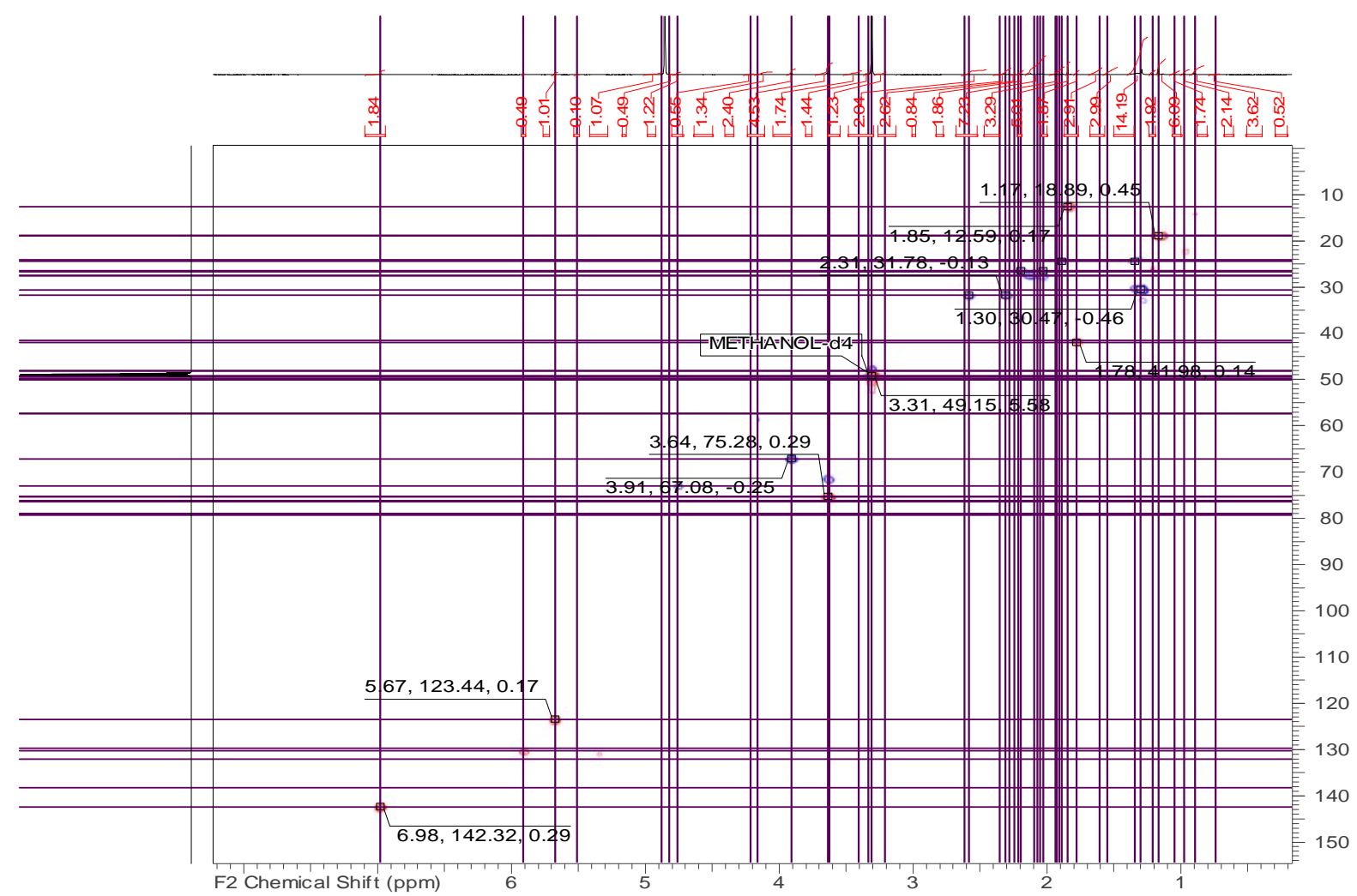

Figure 57: ${ }^{1} \mathrm{H},{ }^{13} \mathrm{C}$ HMBC NMR spectrum of elgonene E (6) in methanol $\mathrm{d}_{4}(700 \mathrm{MHz}, 125$ $\mathrm{MHz})$

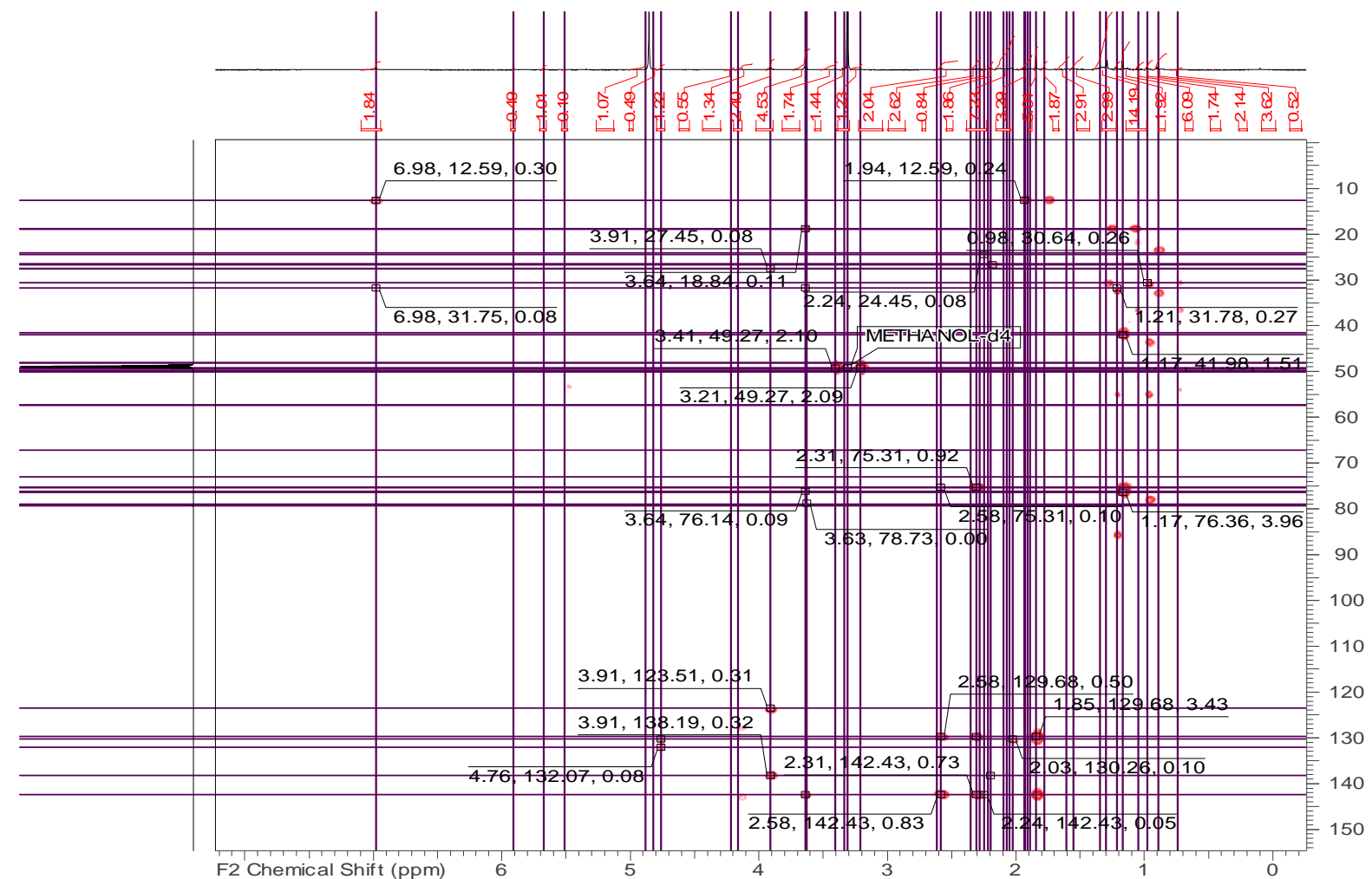


Figure 58: ${ }^{1} \mathrm{H},{ }^{1} \mathrm{H}$ COSY NMR spectrum of elgonene E (6) in methanol $\mathrm{d}_{4}(700 \mathrm{MHz})$

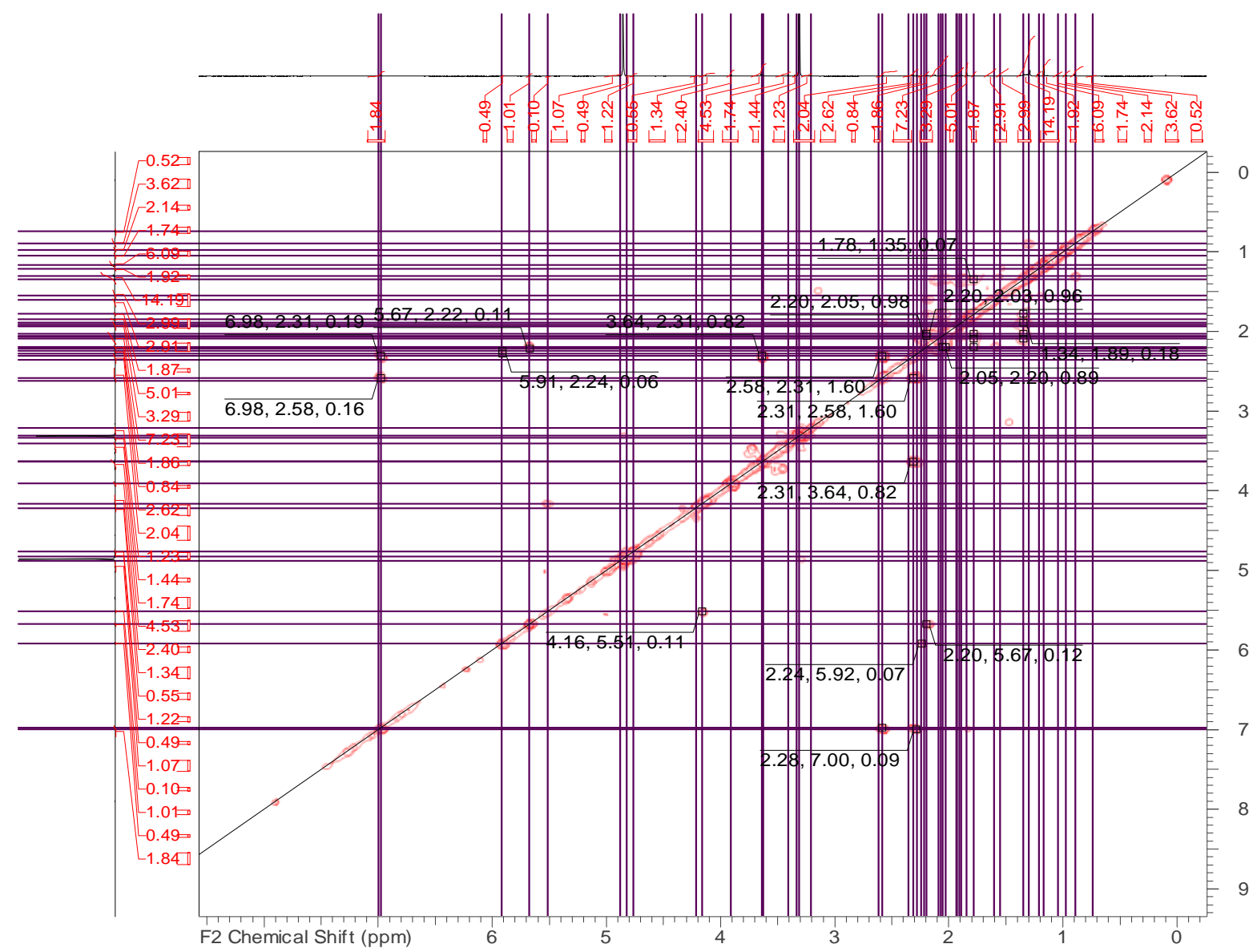

Figure 59: ${ }^{1} \mathrm{H},{ }^{1} \mathrm{H}$ ROESY NMR spectrum of elgonene $\mathrm{E}(6)$ in methanol $\mathrm{d}_{4}(700 \mathrm{MHz})$

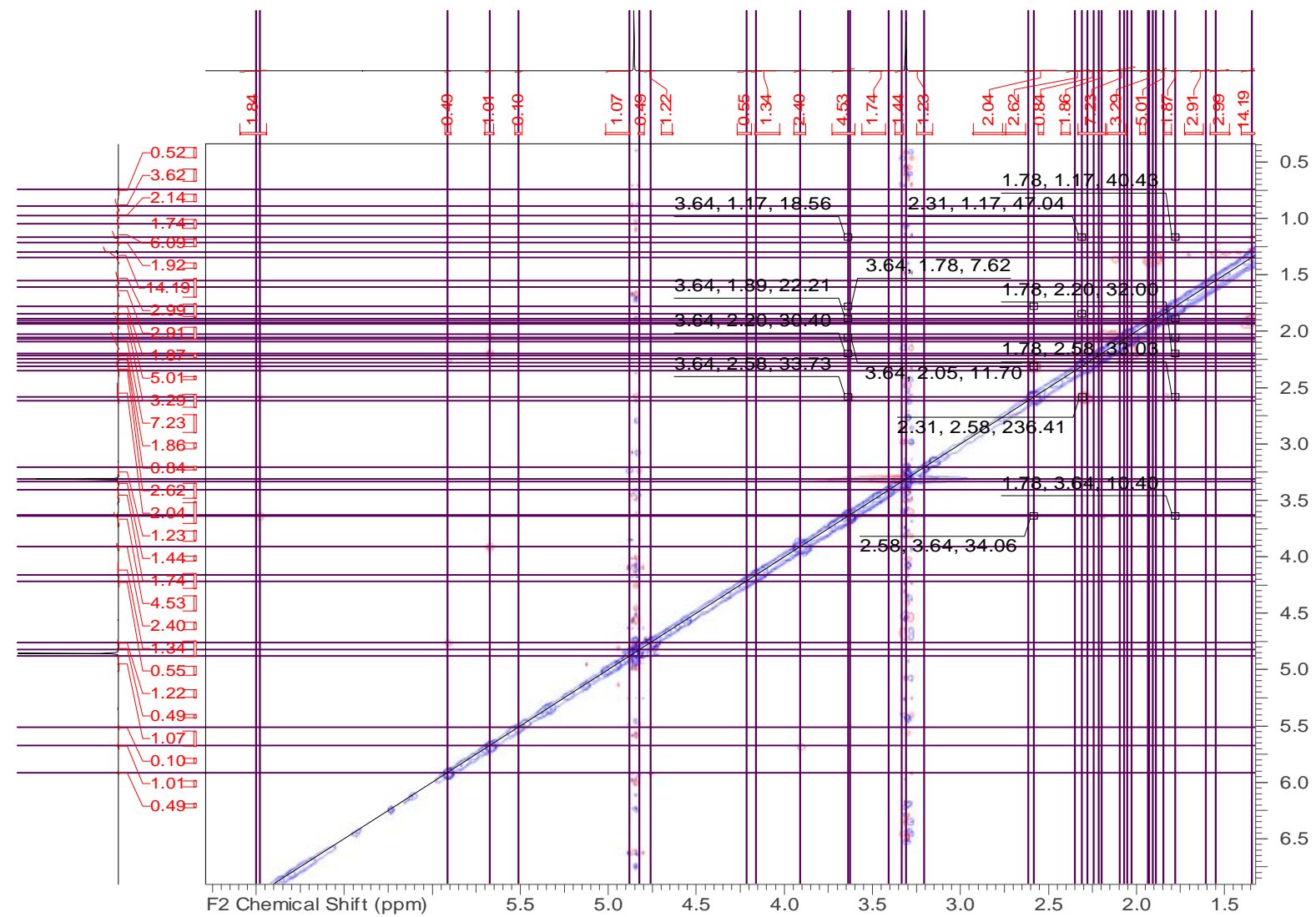


Figure 60: HR-ESIMS spectrum of elgonene E (6)

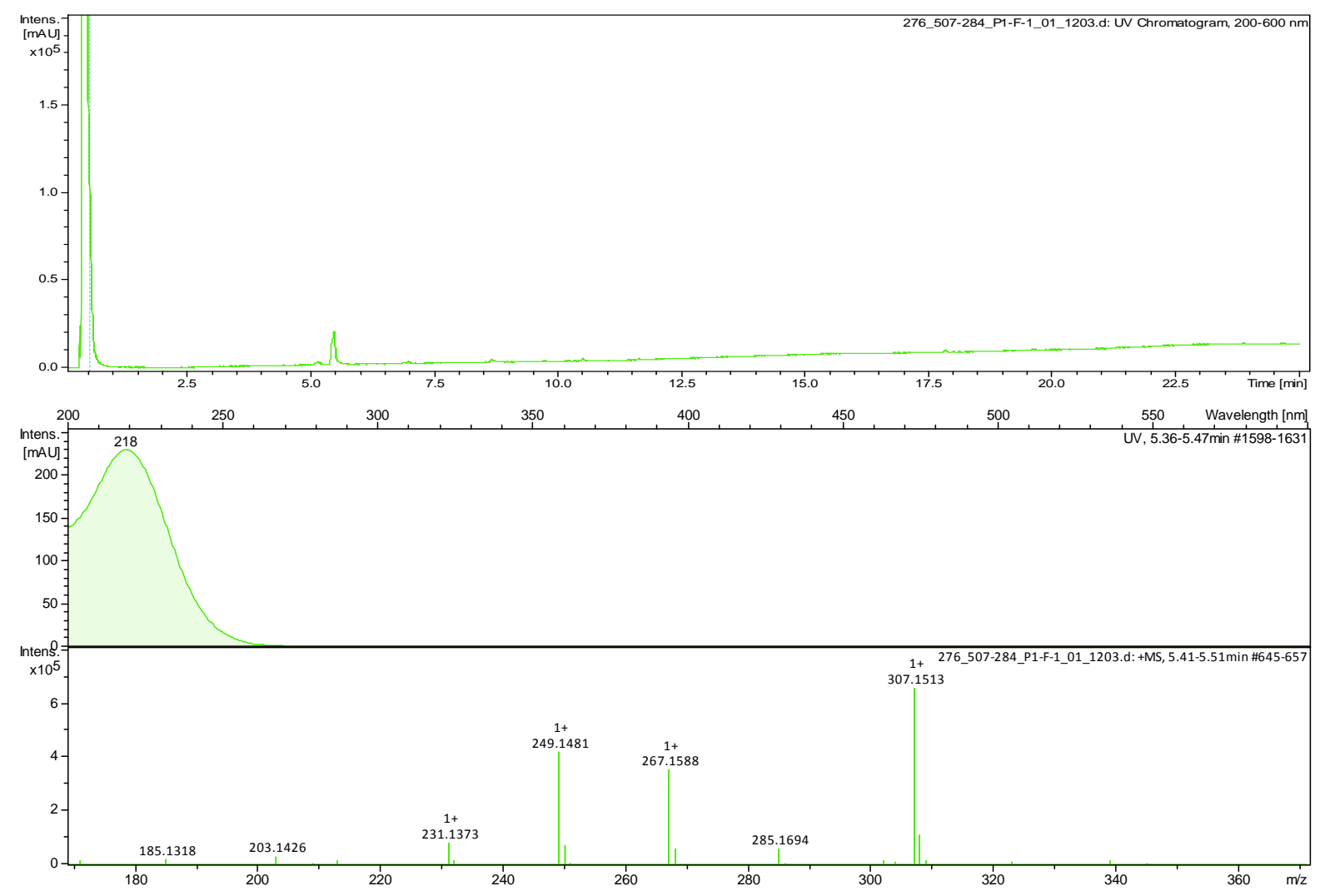

1 and 2D NMR data for elgonene F (7)

Figure 61: ${ }^{1} \mathrm{H}$ NMR spectrum of elgonene $\mathrm{F}(7)$ in $\mathrm{CDCl}_{3}(700 \mathrm{MHz})$

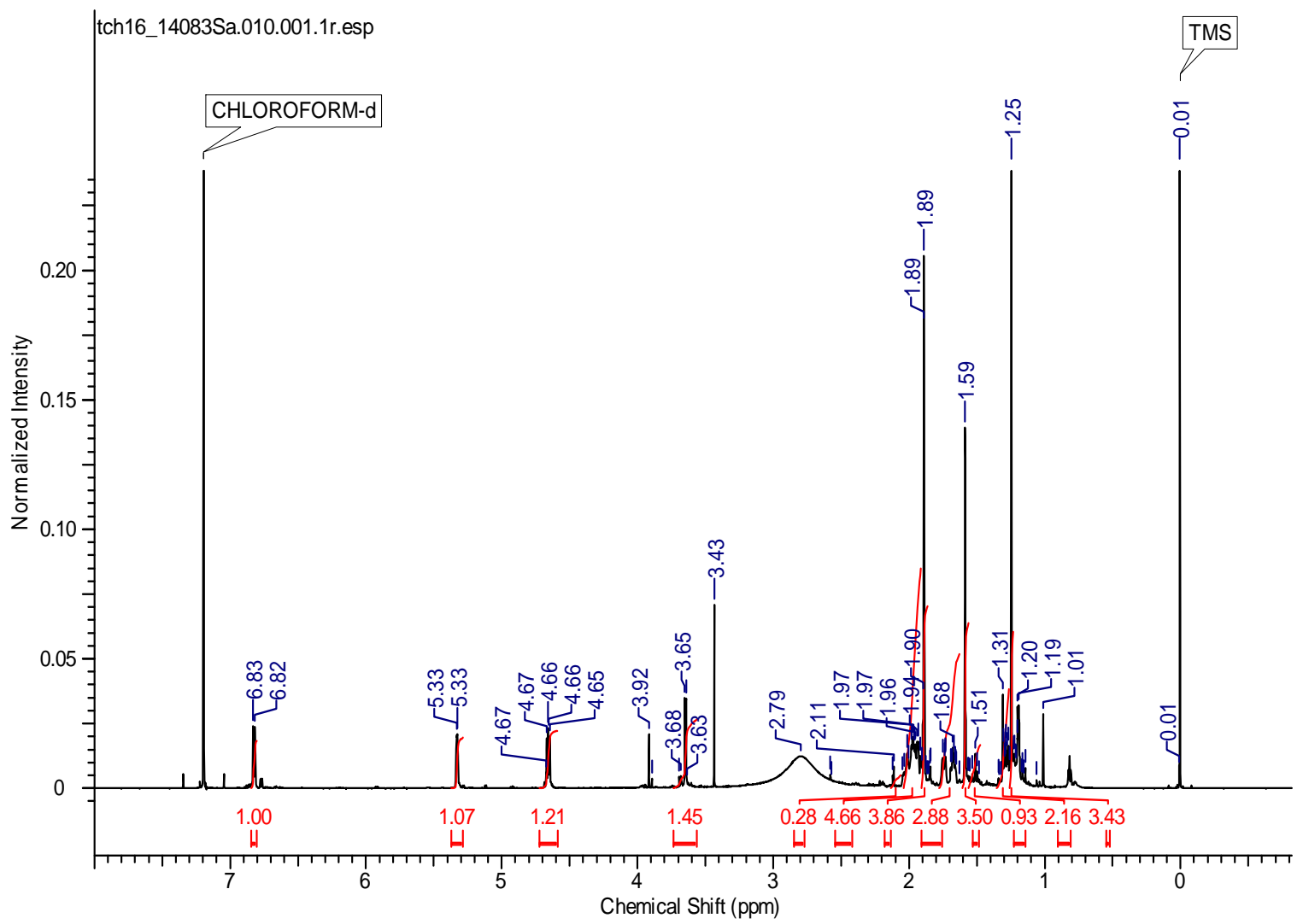


Figure 62: ${ }^{13} \mathrm{C}$ NMR spectrum of elgonene $\mathrm{F}(7)$ in $\mathrm{CDCl}_{3}(175 \mathrm{MHz})$

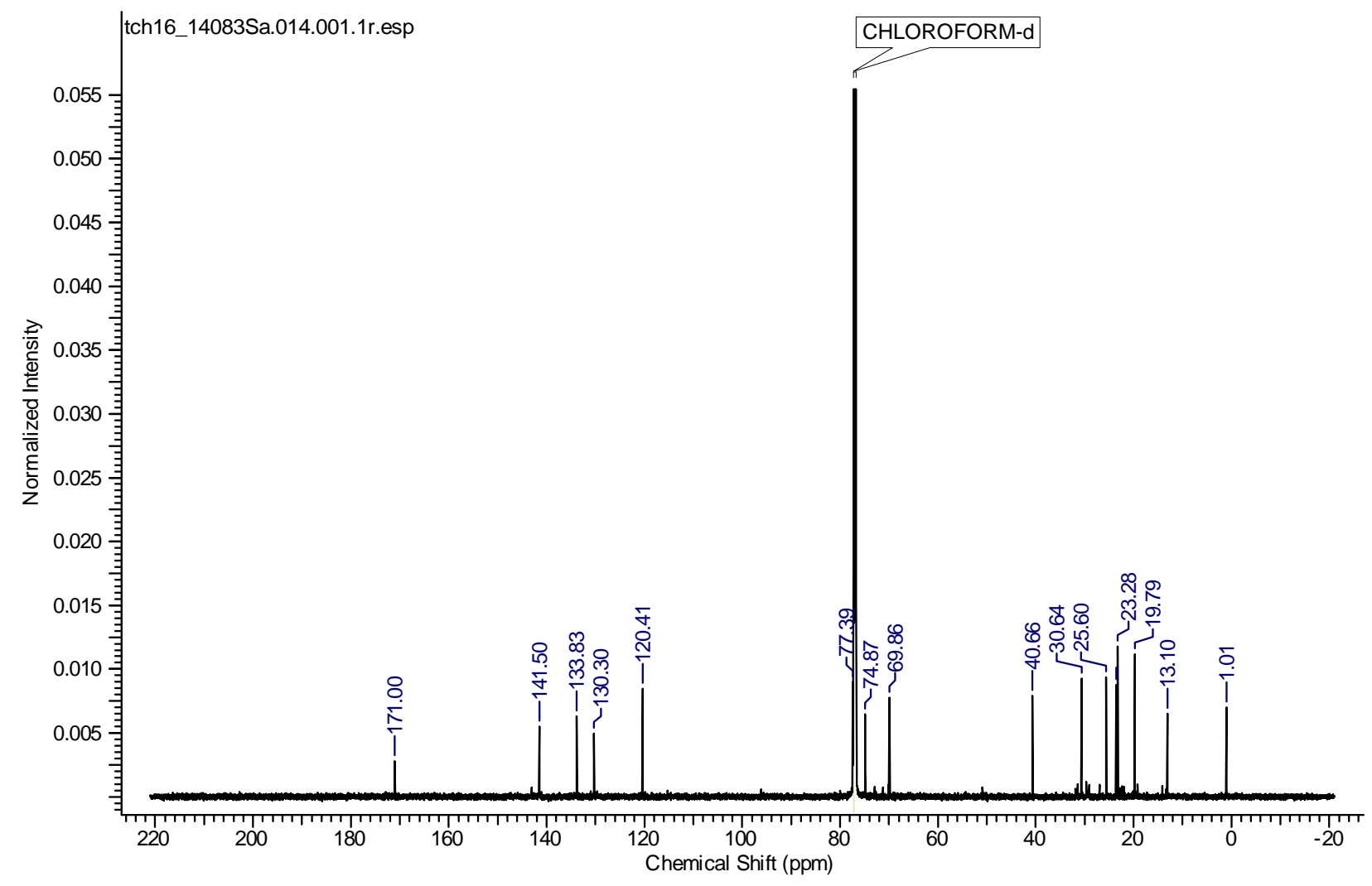

Figure 63: DEPT NMR spectrum of elgonene $\mathrm{F}(7)$ in $\mathrm{CDCl}_{3}(175 \mathrm{MHz})$

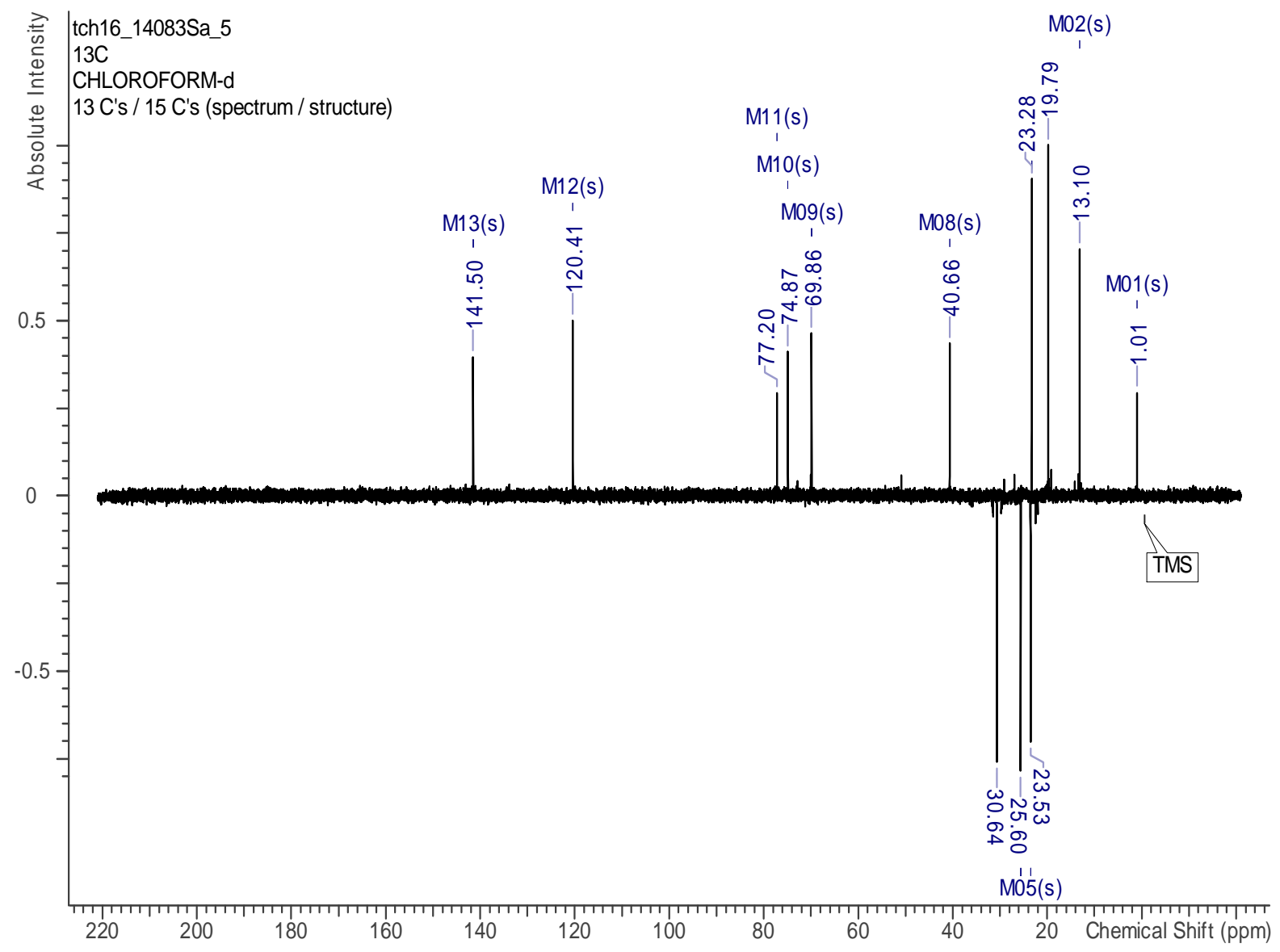


Figure 64: ${ }^{1} \mathrm{H},{ }^{13} \mathrm{C}$ HSQC NMR spectrum of elgonene $\mathrm{F}(7)$ in $\mathrm{CDCl}_{3}(700 \mathrm{MHz}, 175 \mathrm{MHz})$

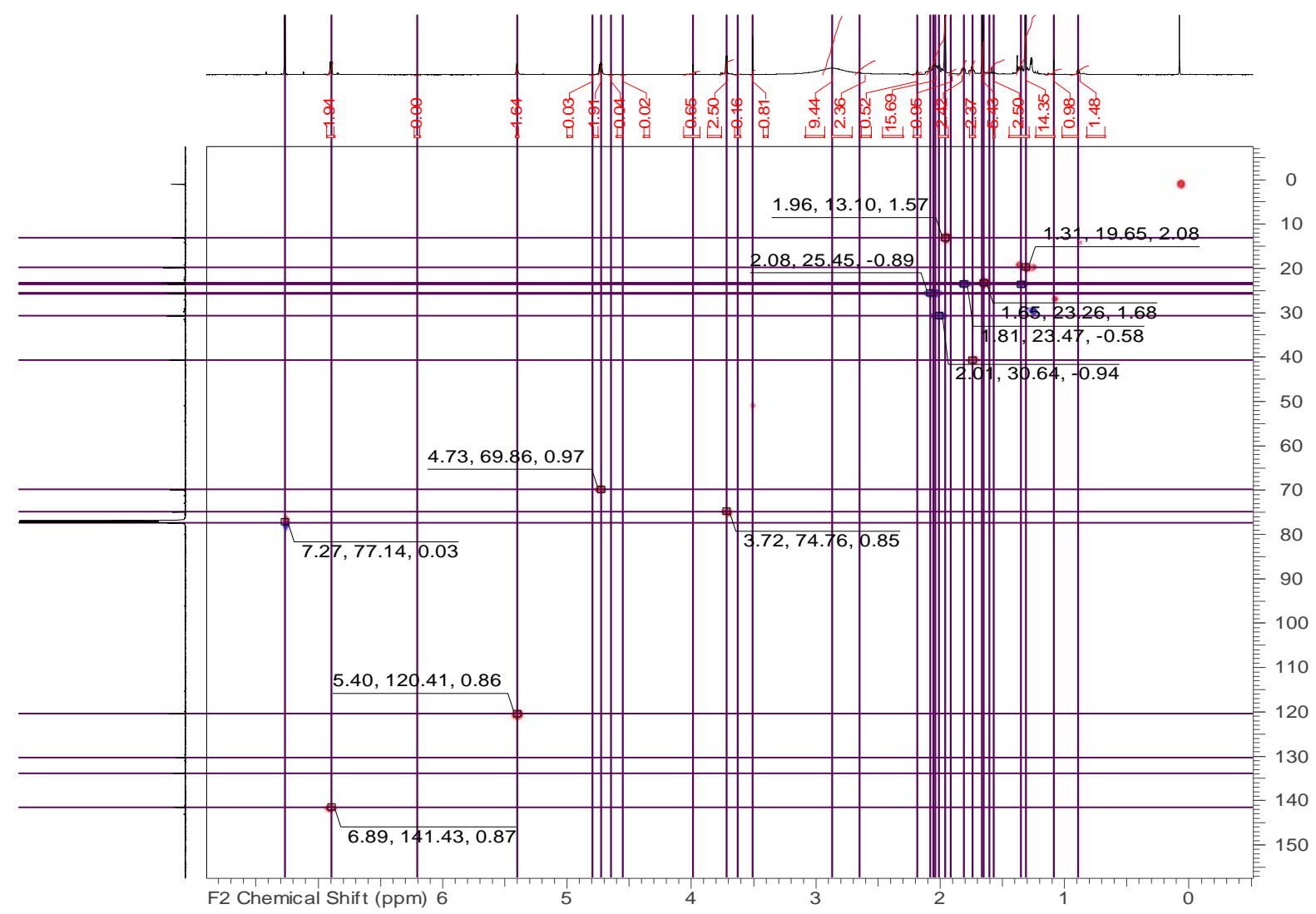

Figure 65: ${ }^{1} \mathrm{H},{ }^{13} \mathrm{C}$ HMBC NMR spectrum of elgonene $\mathrm{F}(7)$ in $\mathrm{CDCl} 3(700 \mathrm{MHz}, 175 \mathrm{MHz}$ )

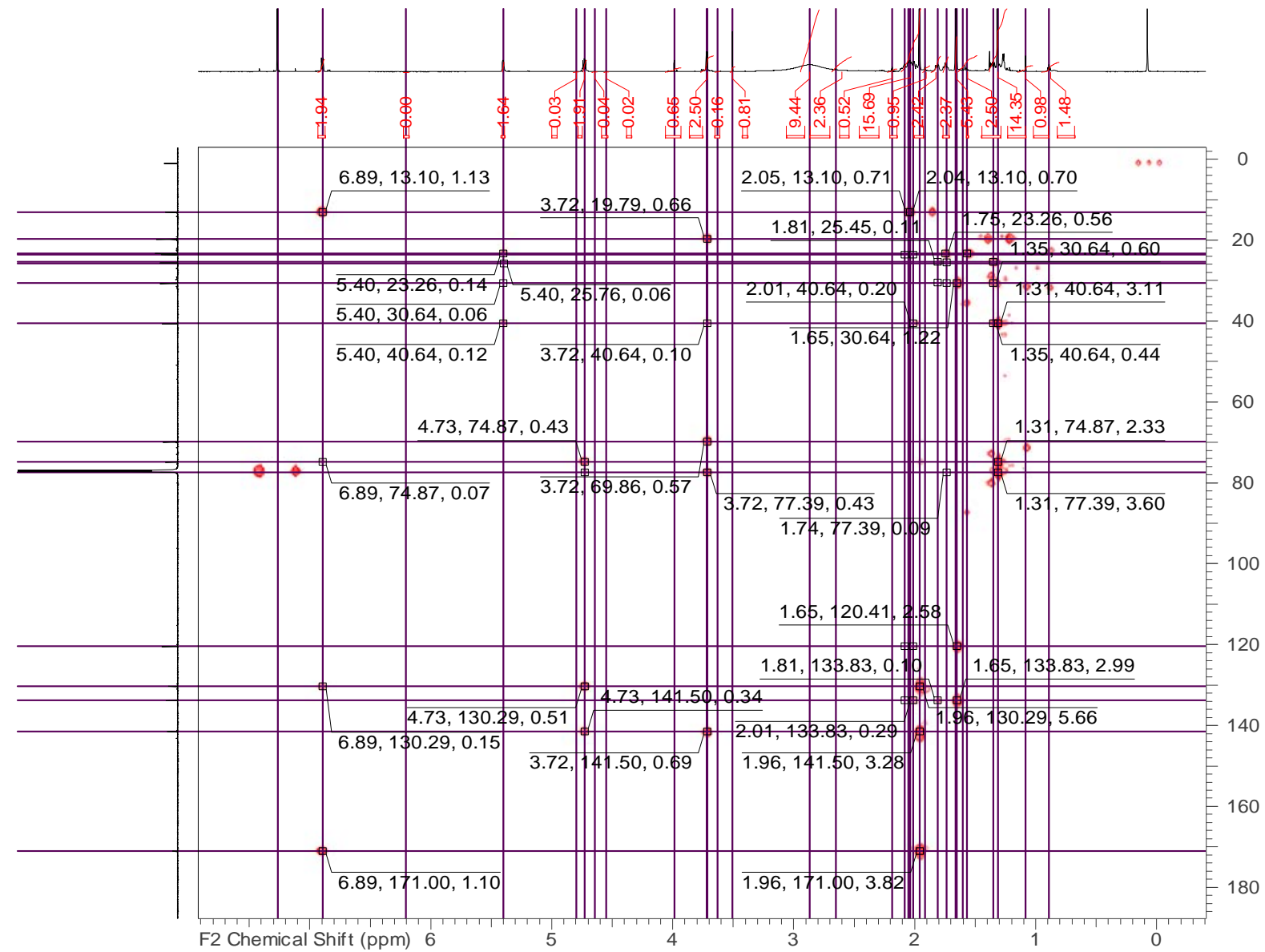


Figure 66: ${ }^{1} \mathrm{H},{ }^{1} \mathrm{H}$ COSY NMR spectrum of elgonene F (7) in CDCl3 (700 MHz)

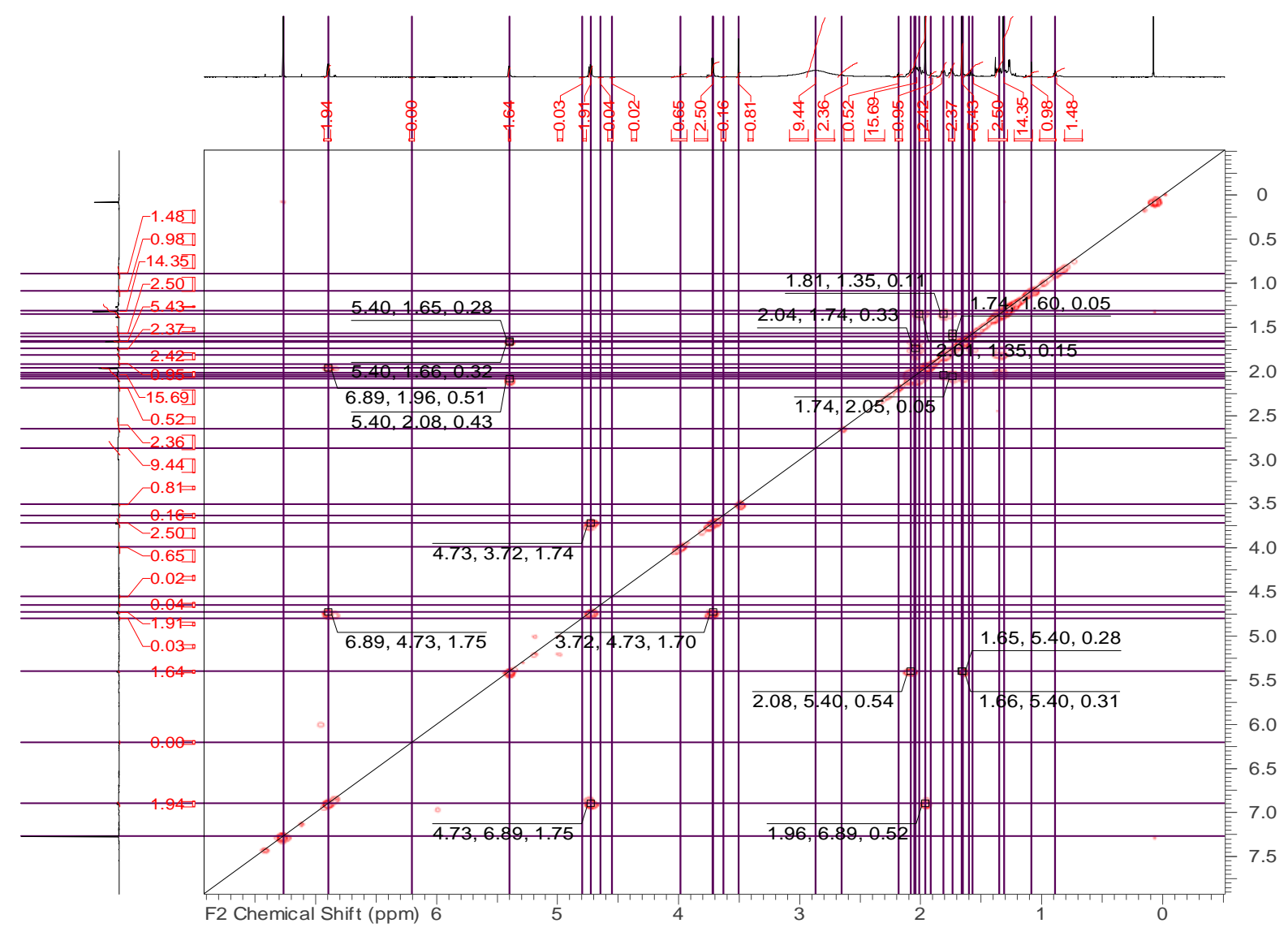

Figure 67: ${ }^{1} \mathrm{H},{ }^{1} \mathrm{H}$ ROESY NMR spectrum of elgonene $\mathrm{F}(7)$ in $\mathrm{CDCl}_{3}(700 \mathrm{MHz})$

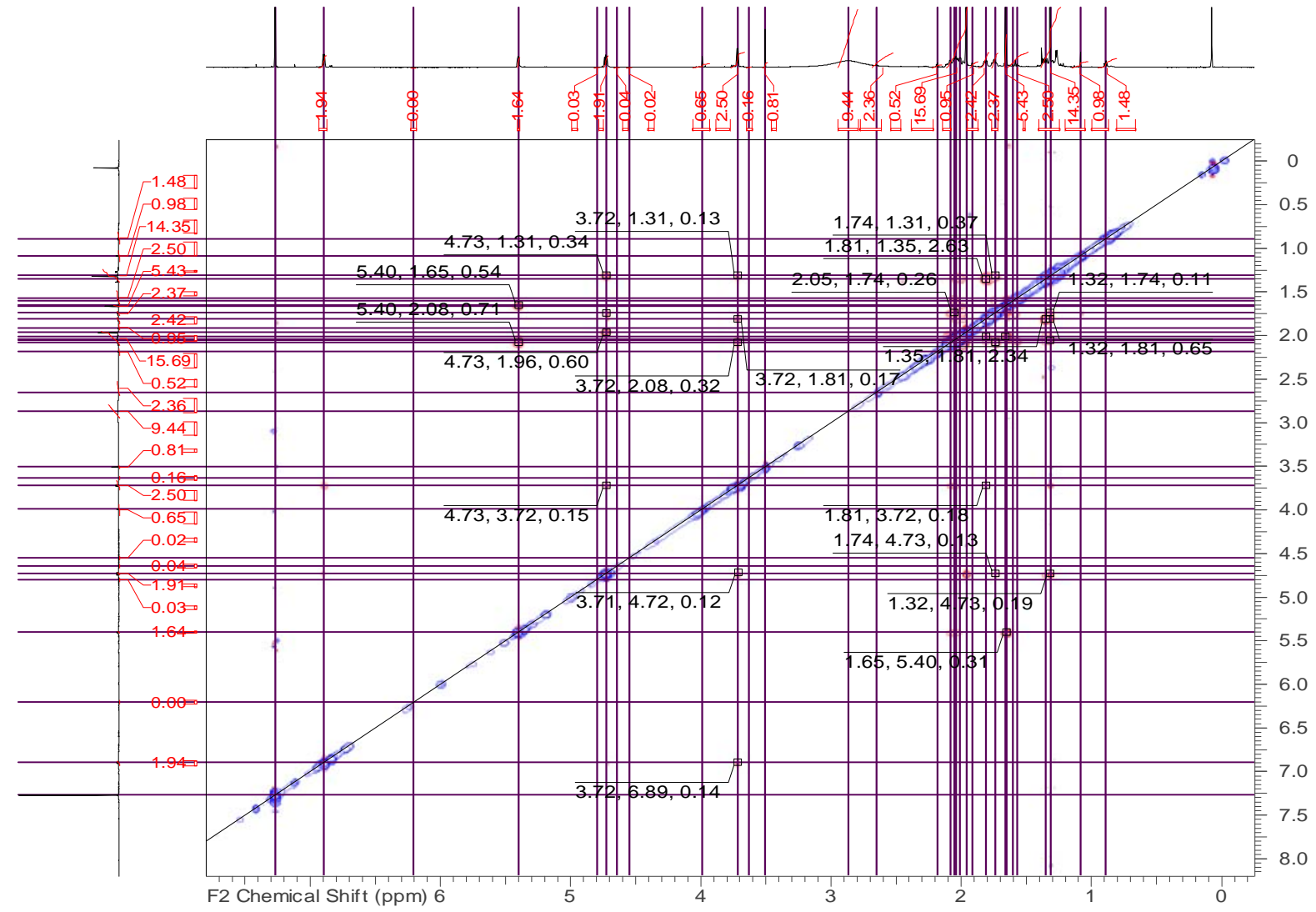


Figure 68: HR-ESIMS spectrum of elgonene F (7)

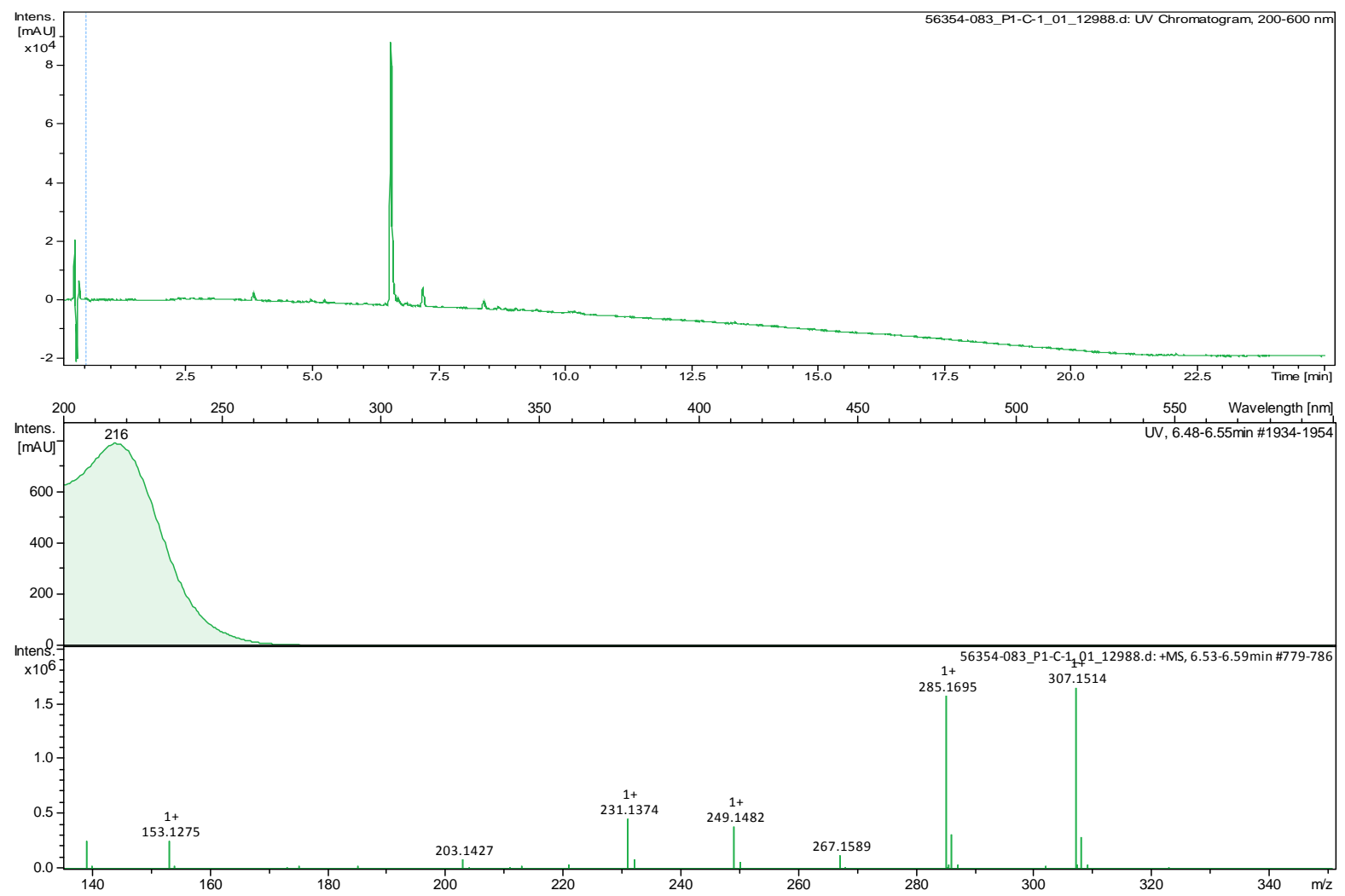

\section{1 and 2D NMR data for elgonene $G(8)$ and $H(9)$}

Figure 69: ${ }^{1} \mathrm{H}$ NMR spectrum of elgonene $\mathrm{G}(\mathbf{8})$ and $\mathrm{H}(\mathbf{9})$ in $\mathrm{CDCl}_{3}(700 \mathrm{MHz})$

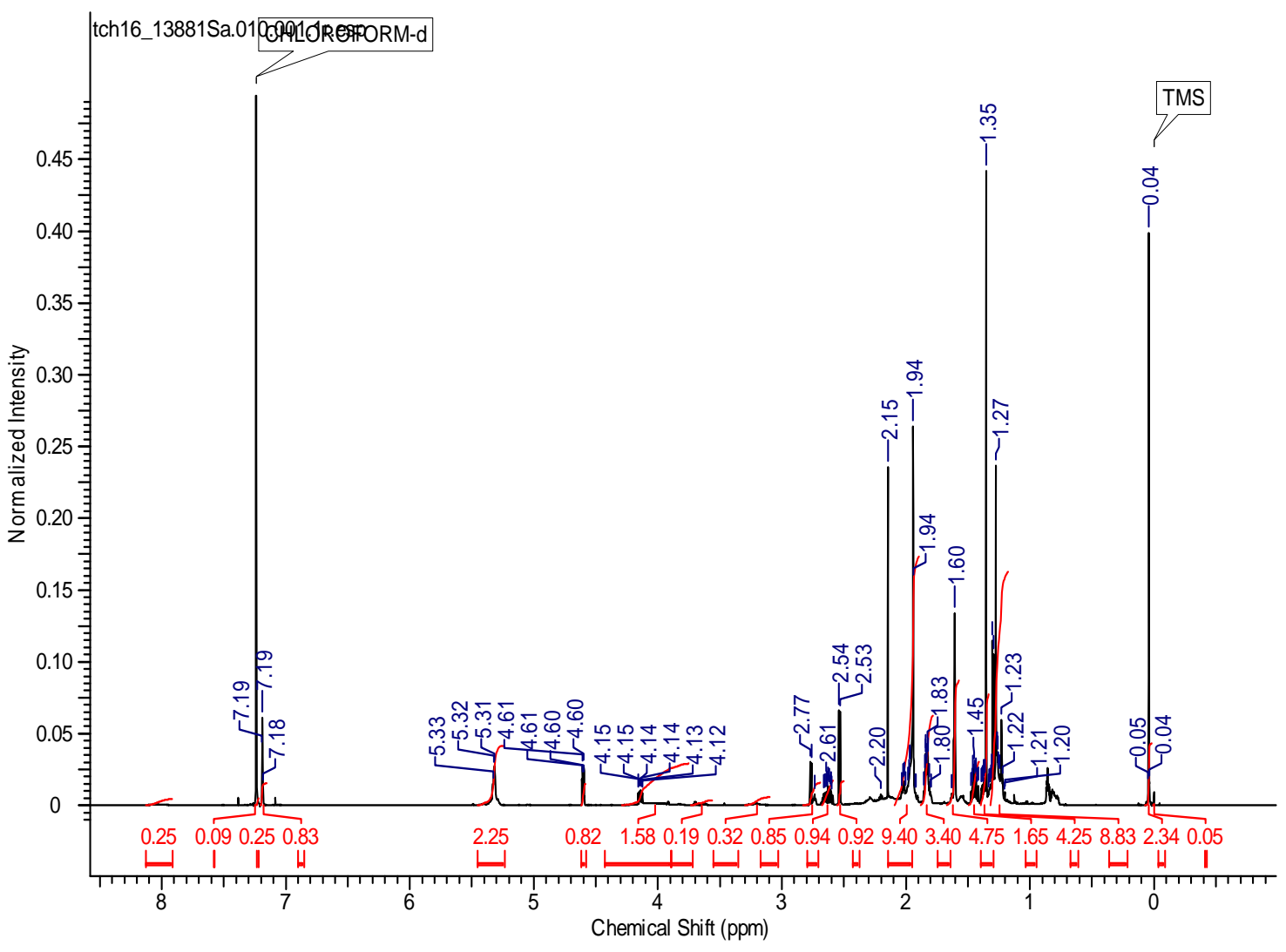


Figure 70: ${ }^{13} \mathrm{C}$ NMR spectrum of elgonene $\mathrm{G}(\mathbf{8})$ and $\mathrm{H}(\mathbf{9})$ in $\mathrm{CDCl}_{3}(175 \mathrm{MHz})$

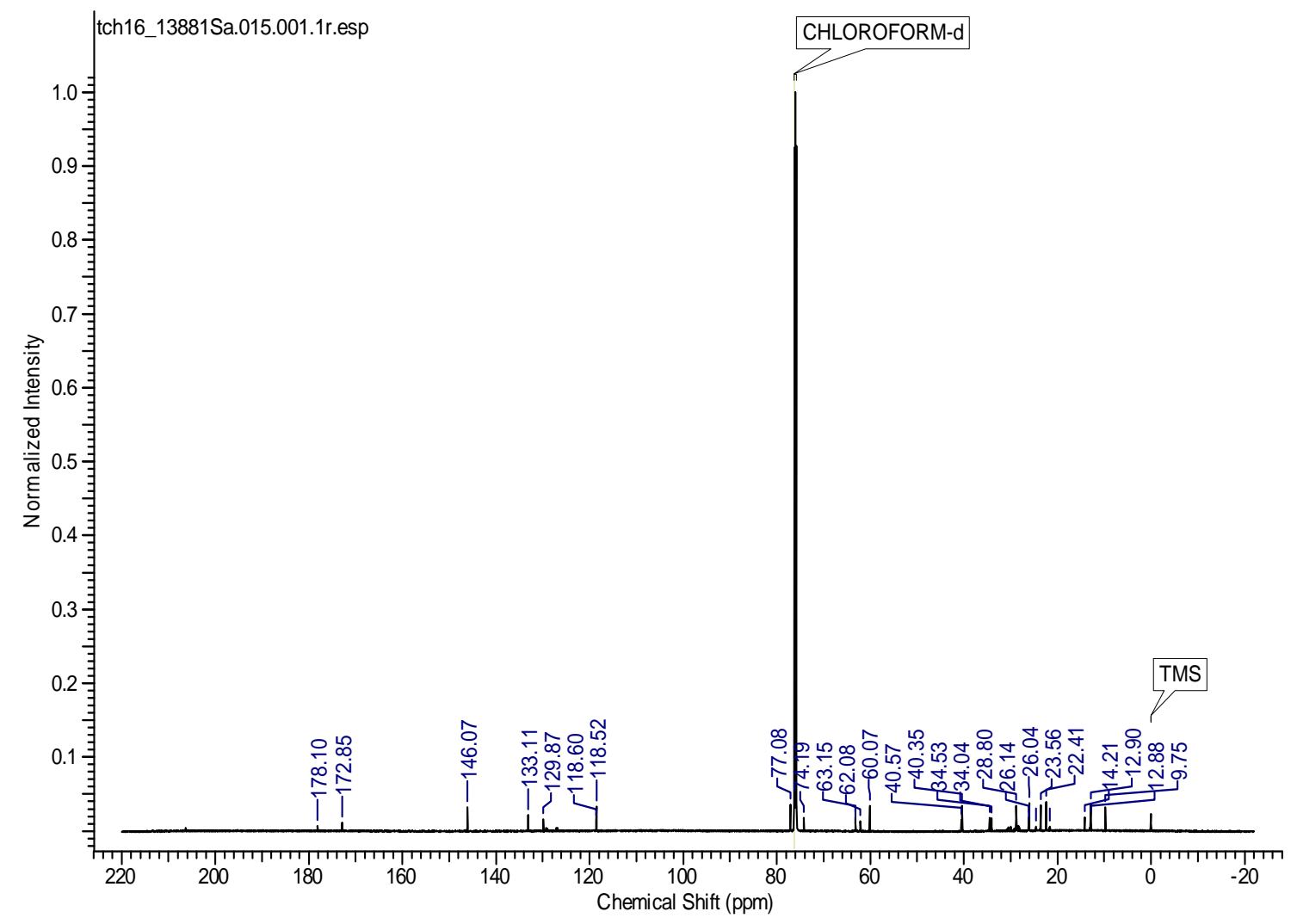

Figure 71: DEPT NMR spectrum of elgonene $\mathrm{G}(\mathbf{8})$ and $\mathrm{H}(\mathbf{9})$ in $\mathrm{CDCl}_{3}(175 \mathrm{MHz})$

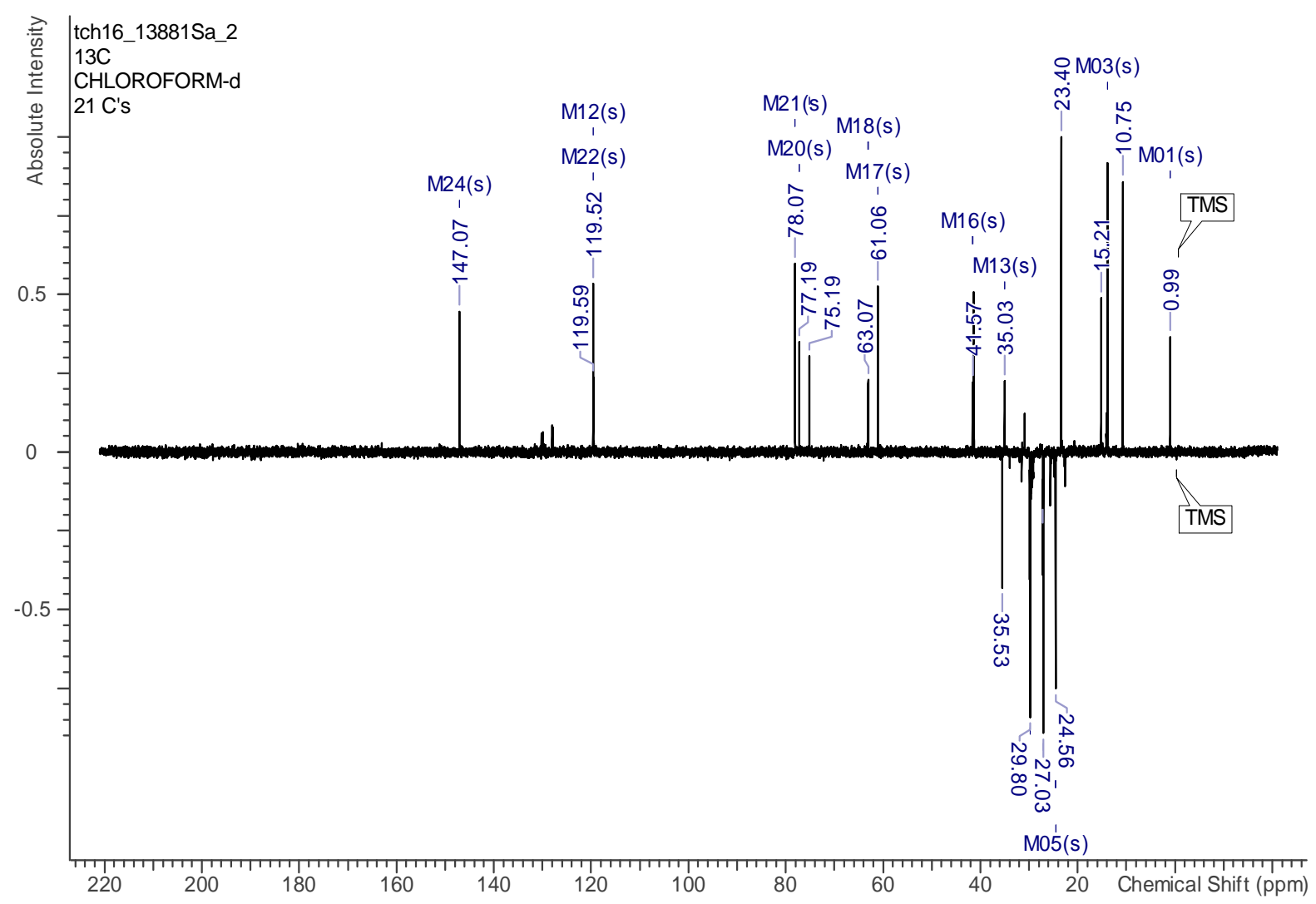


Figure $72:{ }^{1} \mathrm{H},{ }^{13} \mathrm{C}$ HSQC NMR spectrum of elgonene $\mathrm{G}(\mathbf{8})$ and $\mathrm{H}(\mathbf{9})$ in $\mathrm{CDCl}_{3}(700 \mathrm{MHz}$, $175 \mathrm{MHz})$

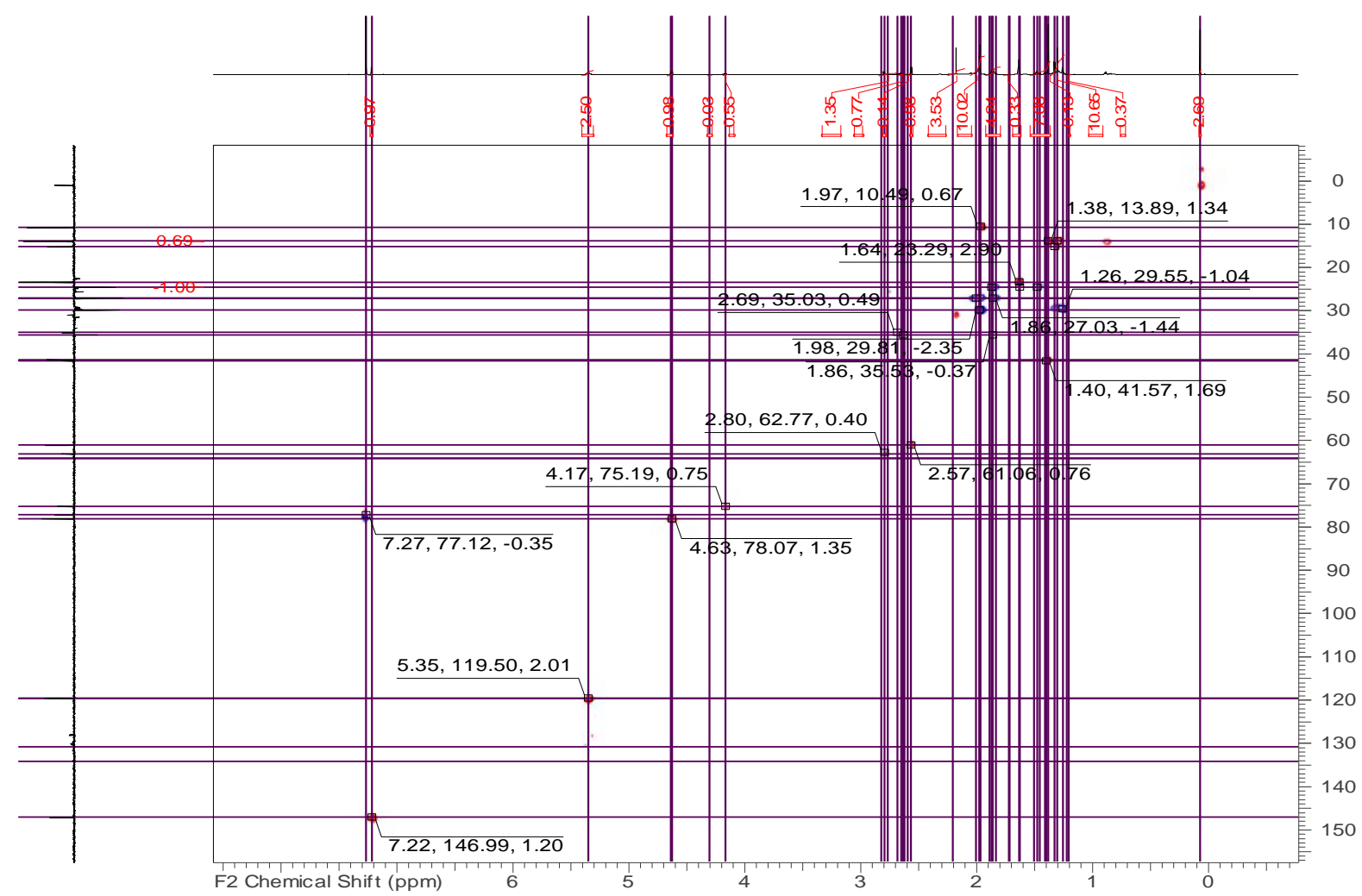

Figure 73: ${ }^{1} \mathrm{H},{ }^{13} \mathrm{C}$ HMBC NMR spectrum of elgonene $\mathrm{G}(\mathbf{8})$ and $\mathrm{H}(\mathbf{9})$ in $\mathrm{CDCl}_{3}(700 \mathrm{MHz}$, $175 \mathrm{MHz})$

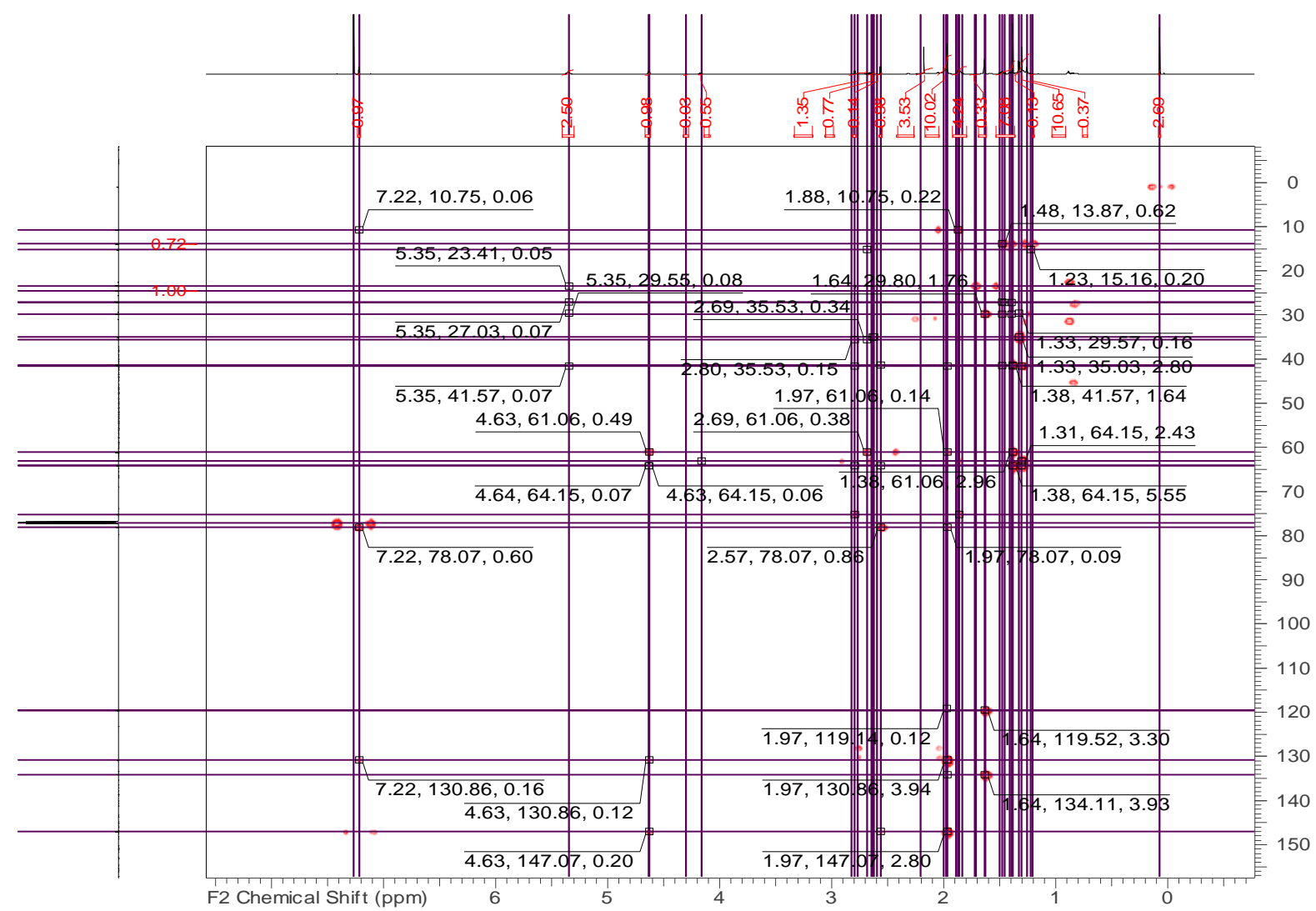


Figure $74:{ }^{1} \mathrm{H},{ }^{1} \mathrm{H}$ COSY NMR spectrum of elgonene $\mathrm{G}(\mathbf{8})$ and $\mathrm{H}(\mathbf{9})$ in $\mathrm{CDCl}_{3}(700 \mathrm{MHz})$

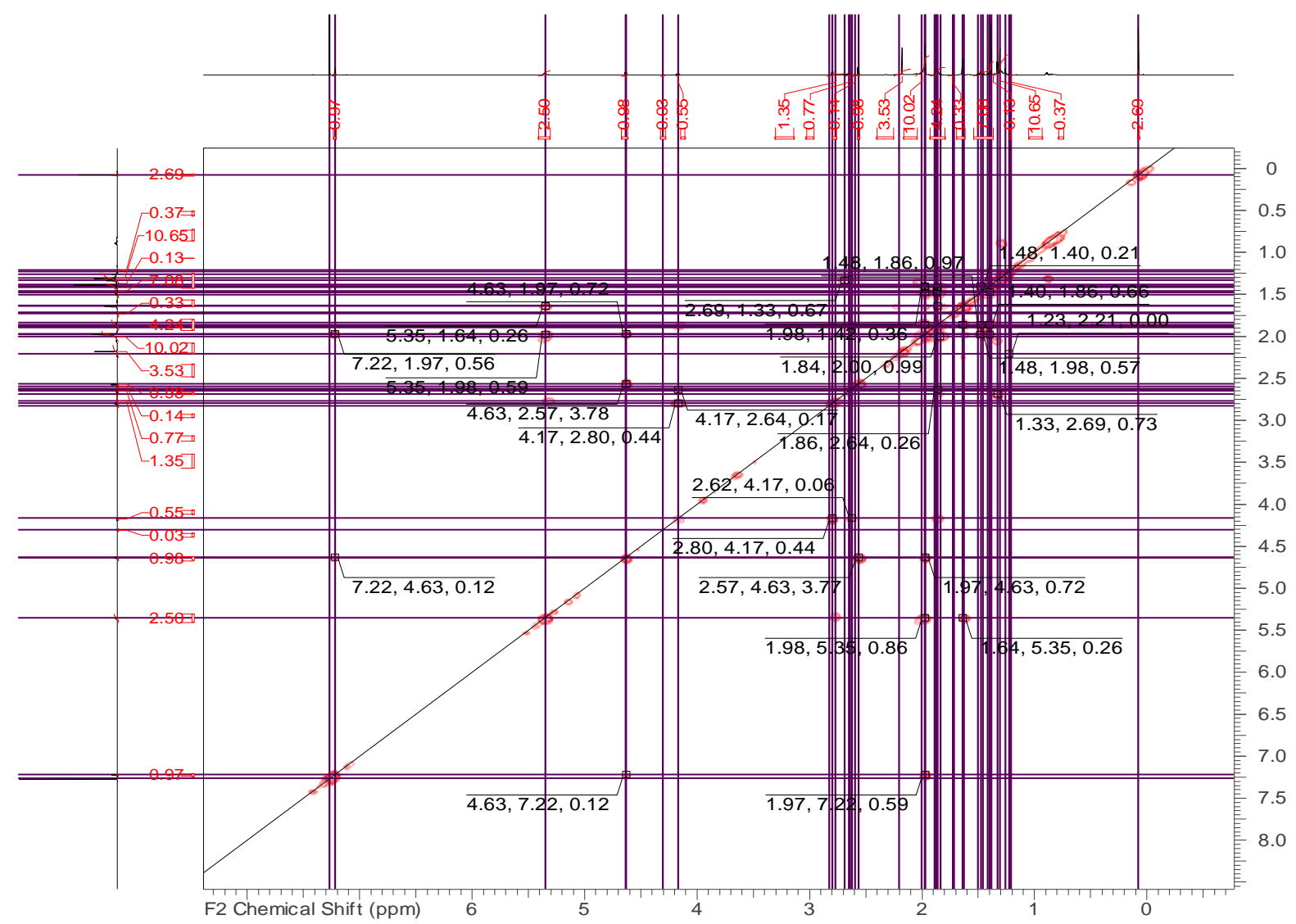

Figure 75: ${ }^{1} \mathrm{H},{ }^{1} \mathrm{H}$ ROESY NMR spectrum of elgonene $\mathrm{G}(\mathbf{8})$ and $\mathrm{H}(\mathbf{9})$ in $\mathrm{CDCl}_{3}(700 \mathrm{MHz})$

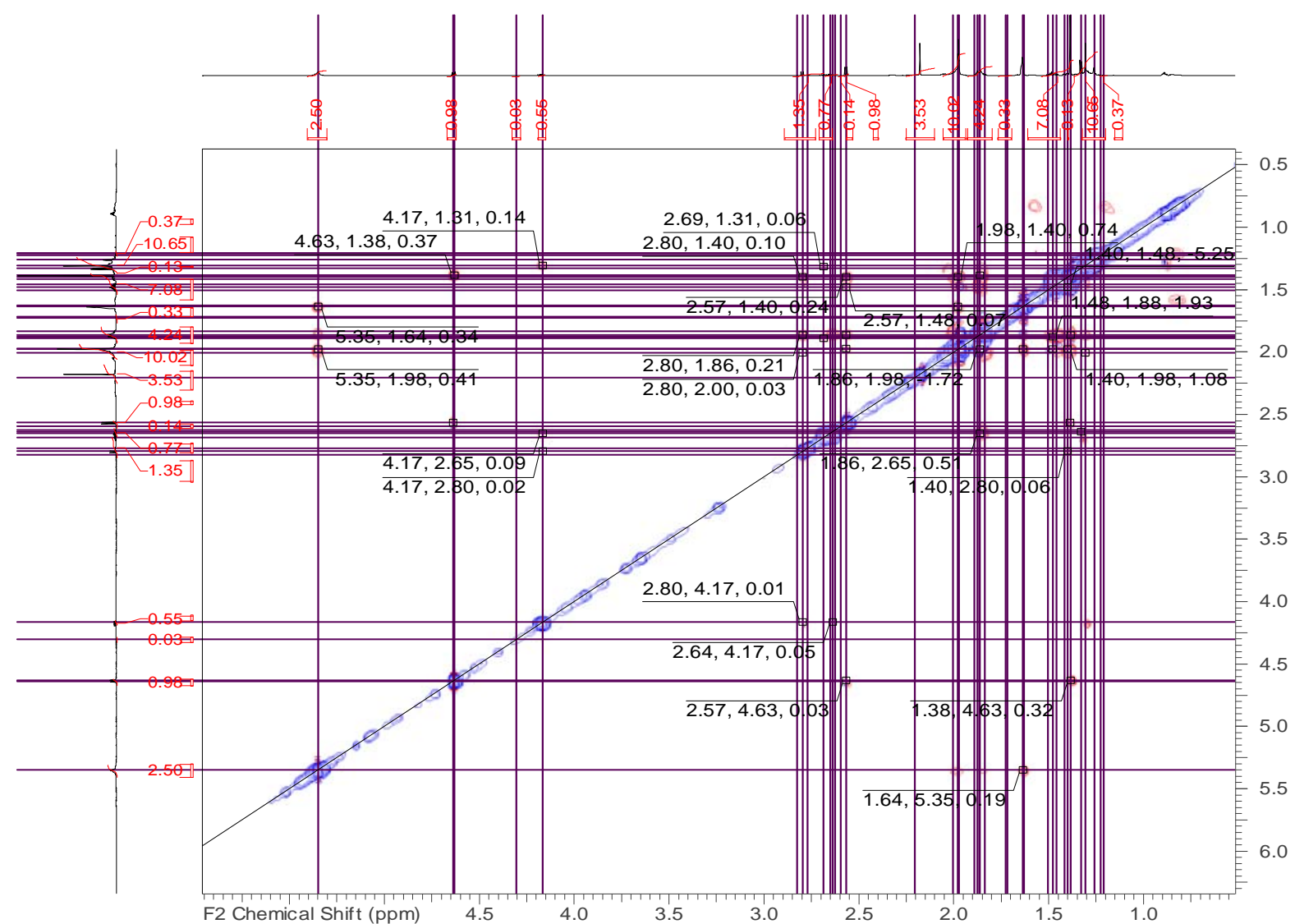


Figure 76: HR-ESIMS spectrum of elgonene G (8) and H (9)
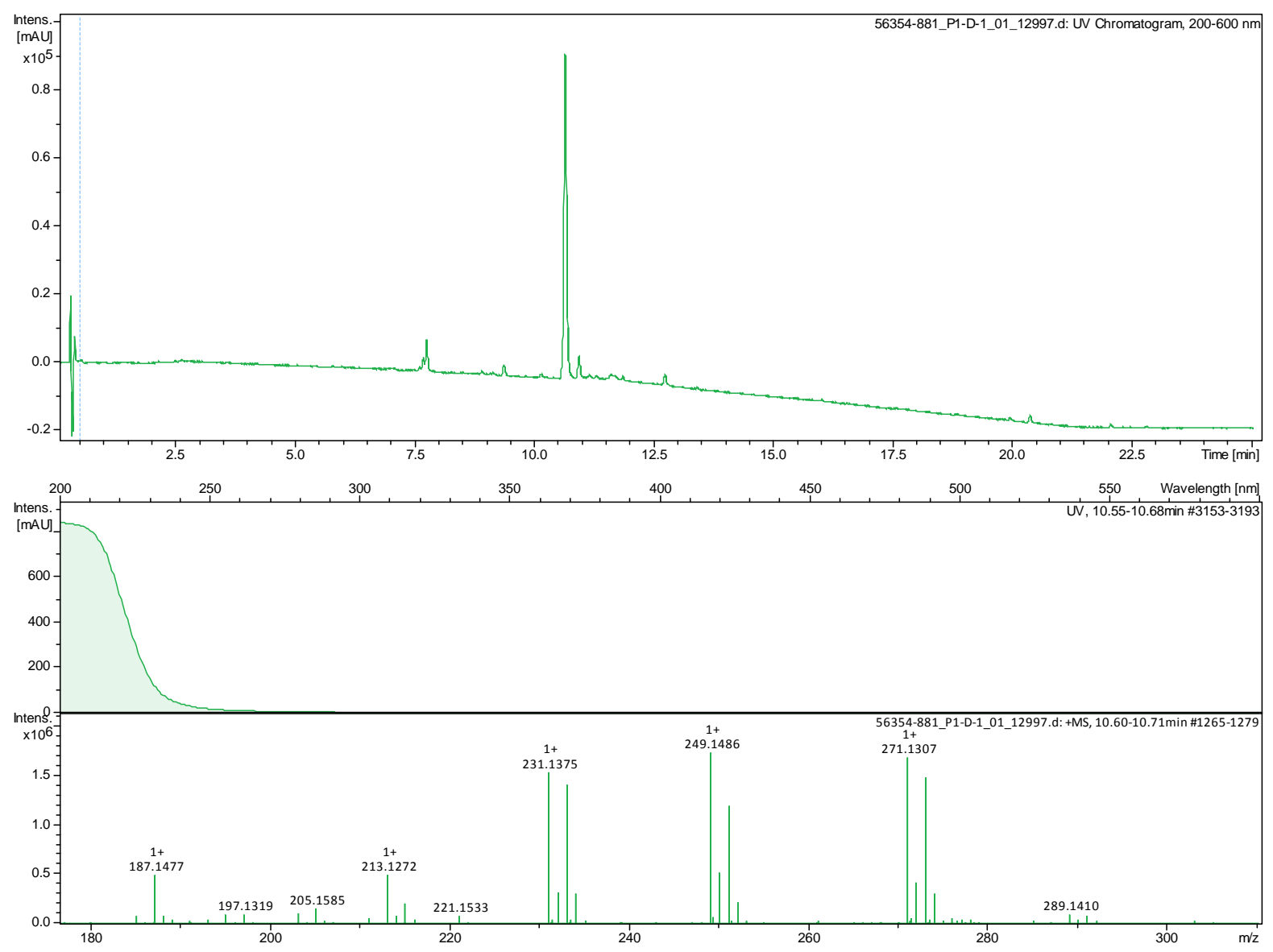

\section{1 and 2D NMR data for elgonene I (10)}

Figure 77: ${ }^{1} \mathrm{H}$ NMR spectrum of elgonene I (10) in acetone- $\mathrm{d}_{6}(500 \mathrm{MHz})$

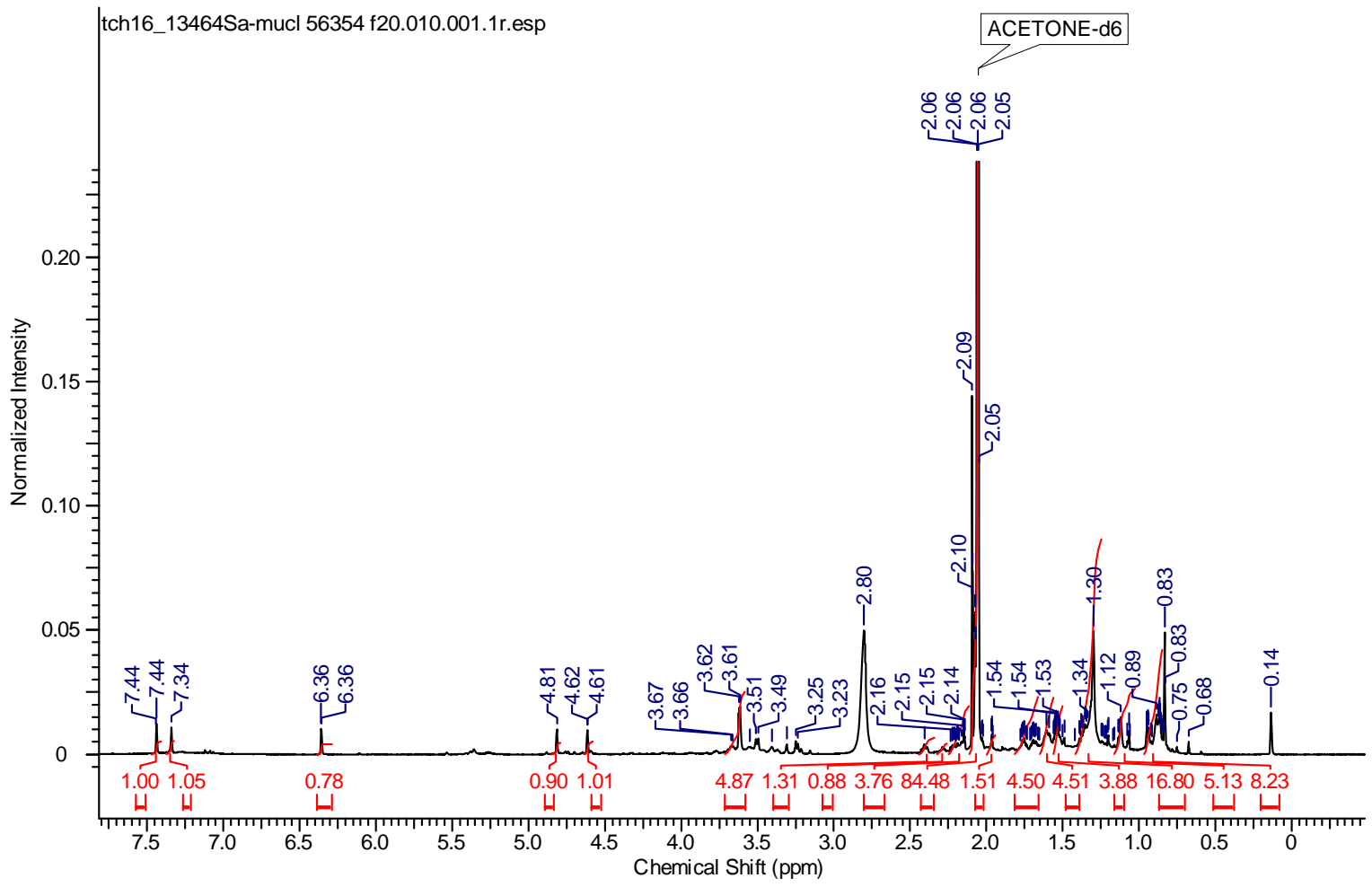


Figure 78: ${ }^{13} \mathrm{C}$ NMR spectrum of elgonene I (10) in acetone- $\mathrm{d}_{6}(125 \mathrm{MHz})$

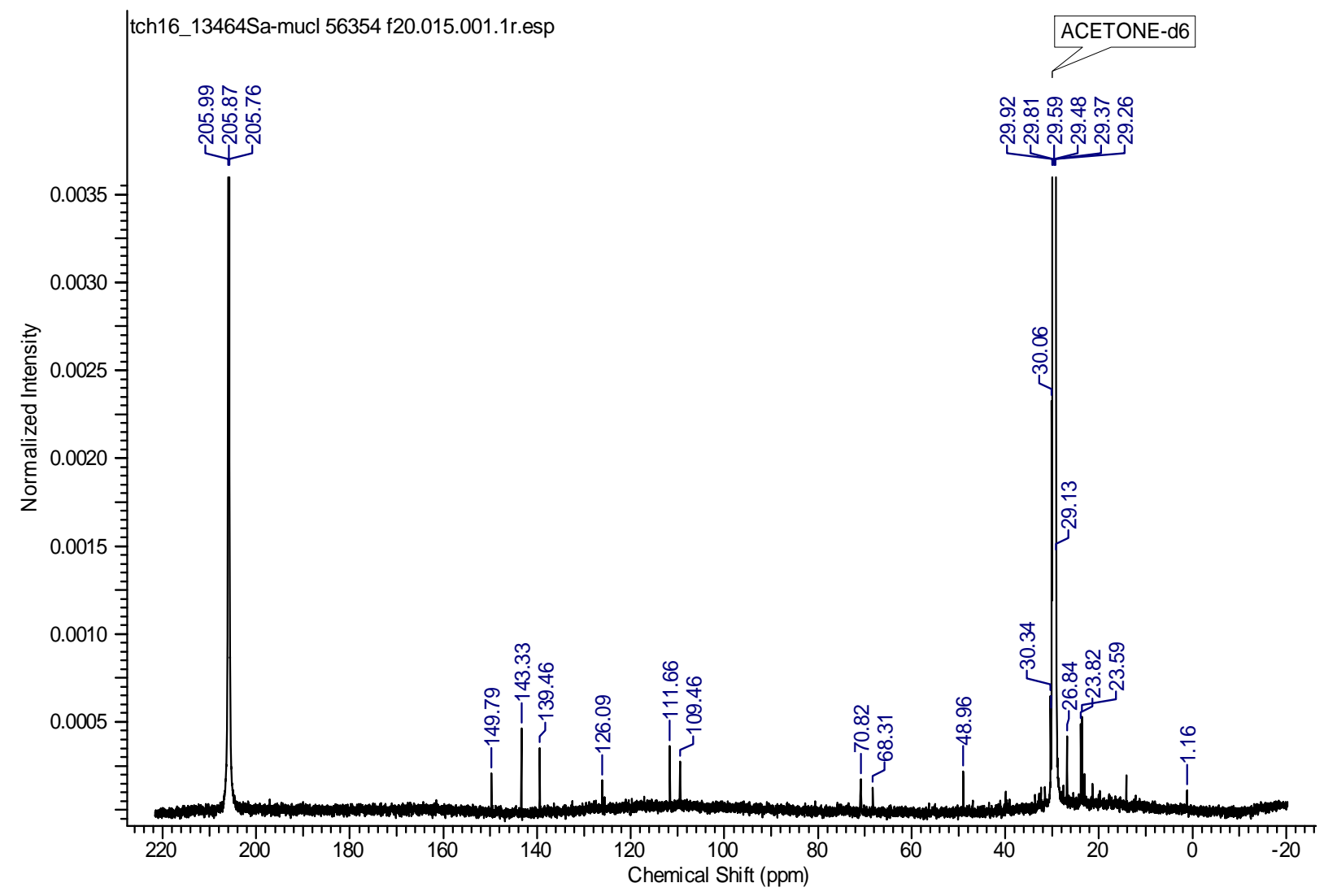

Figure 79: DEPT NMR spectrum of elgonene I (10) in acetone- $\mathrm{d}_{6}(125 \mathrm{MHz})$

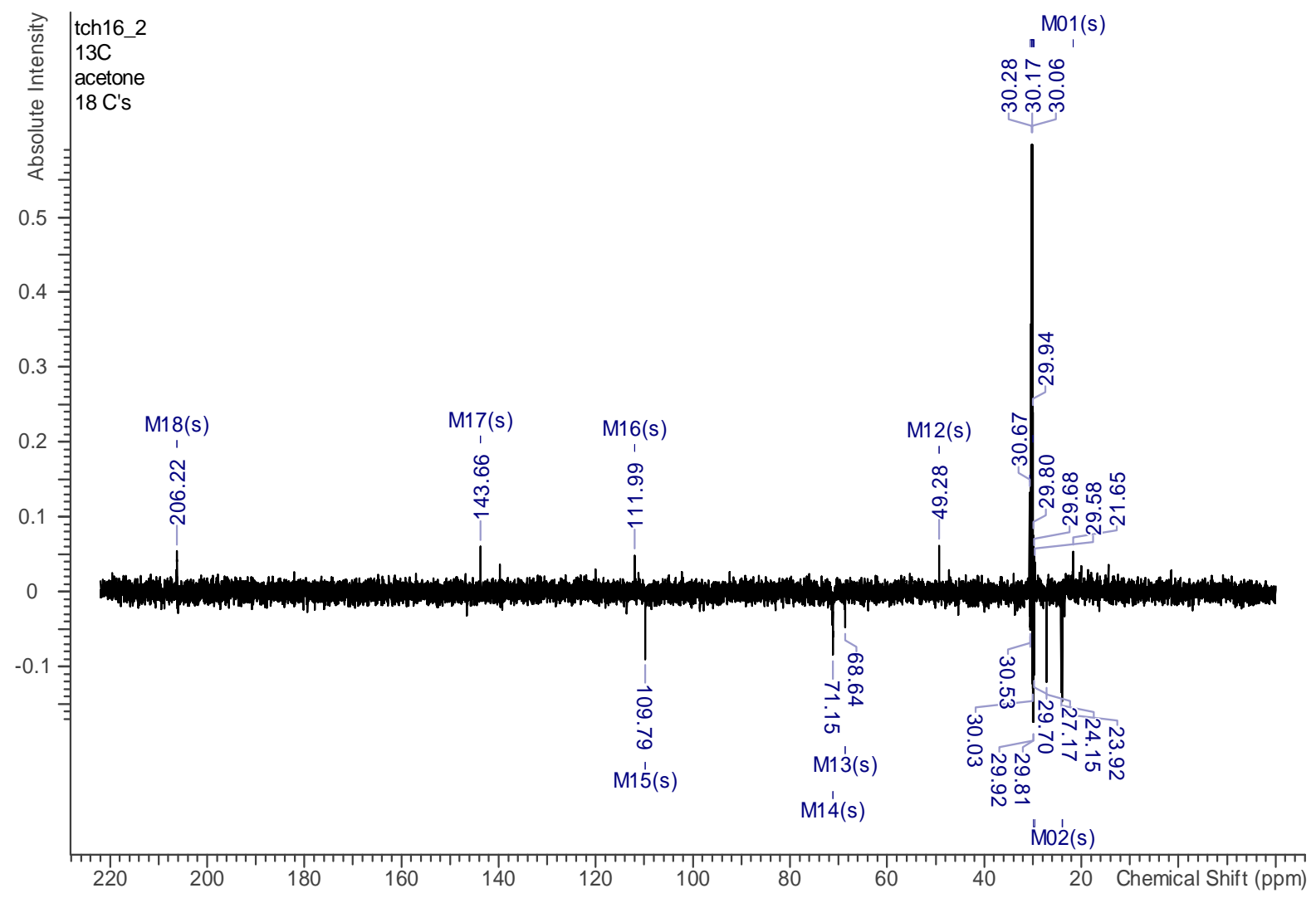


Figure 80: ${ }^{1} \mathrm{H},{ }^{13} \mathrm{C}$ HSQC NMR spectrum of elgonene I (10) in acetone- $\mathrm{d}_{6}(500 \mathrm{MHz}, 125$ $\mathrm{MHz}$

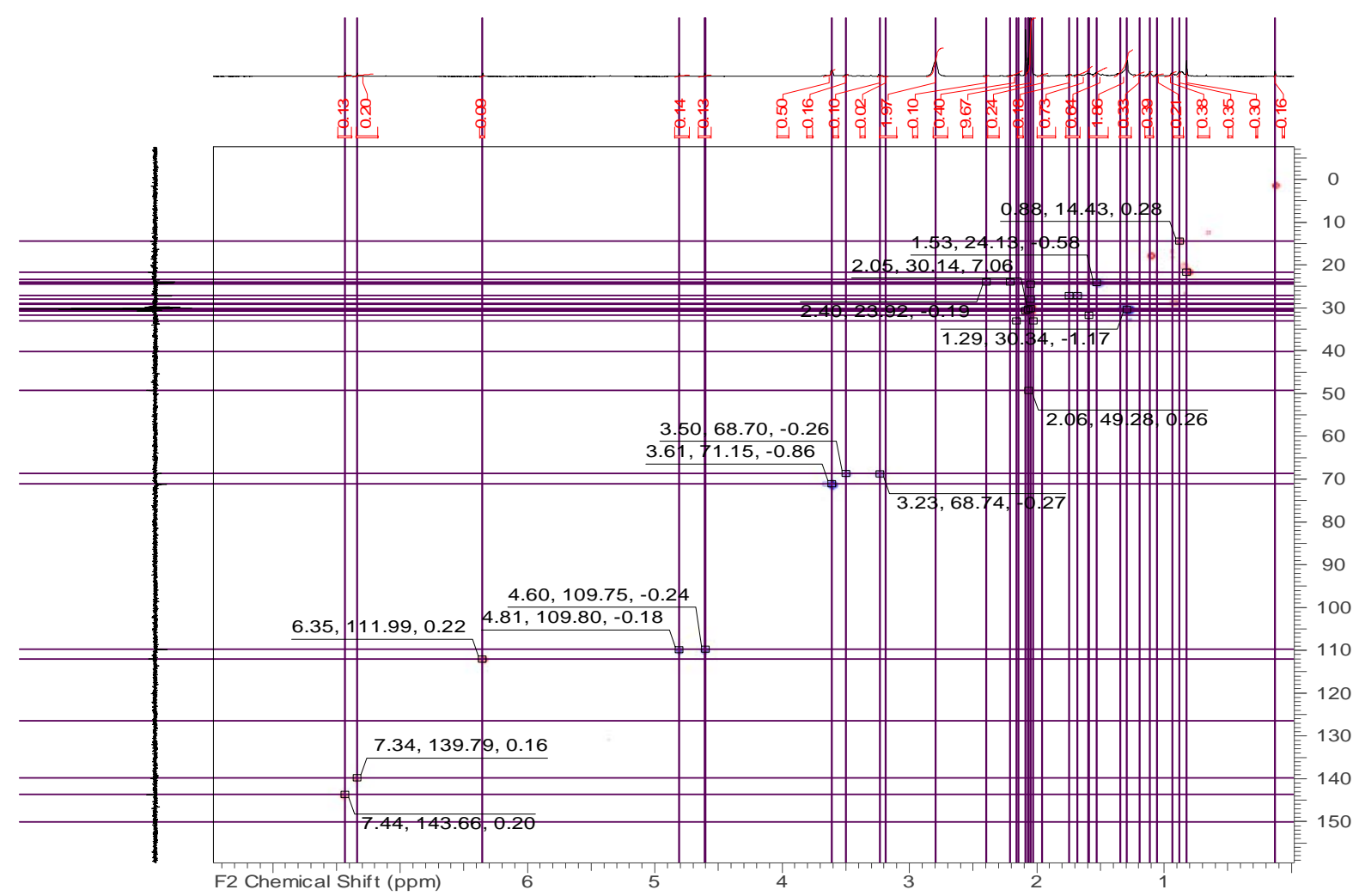

Figure 81: ${ }^{1} \mathrm{H},{ }^{13} \mathrm{C}$ HMBC NMR spectrum of elgonene I (10) in acetone- $\mathrm{d}_{6}(500 \mathrm{MHz}, 125$ $\mathrm{MHz})$

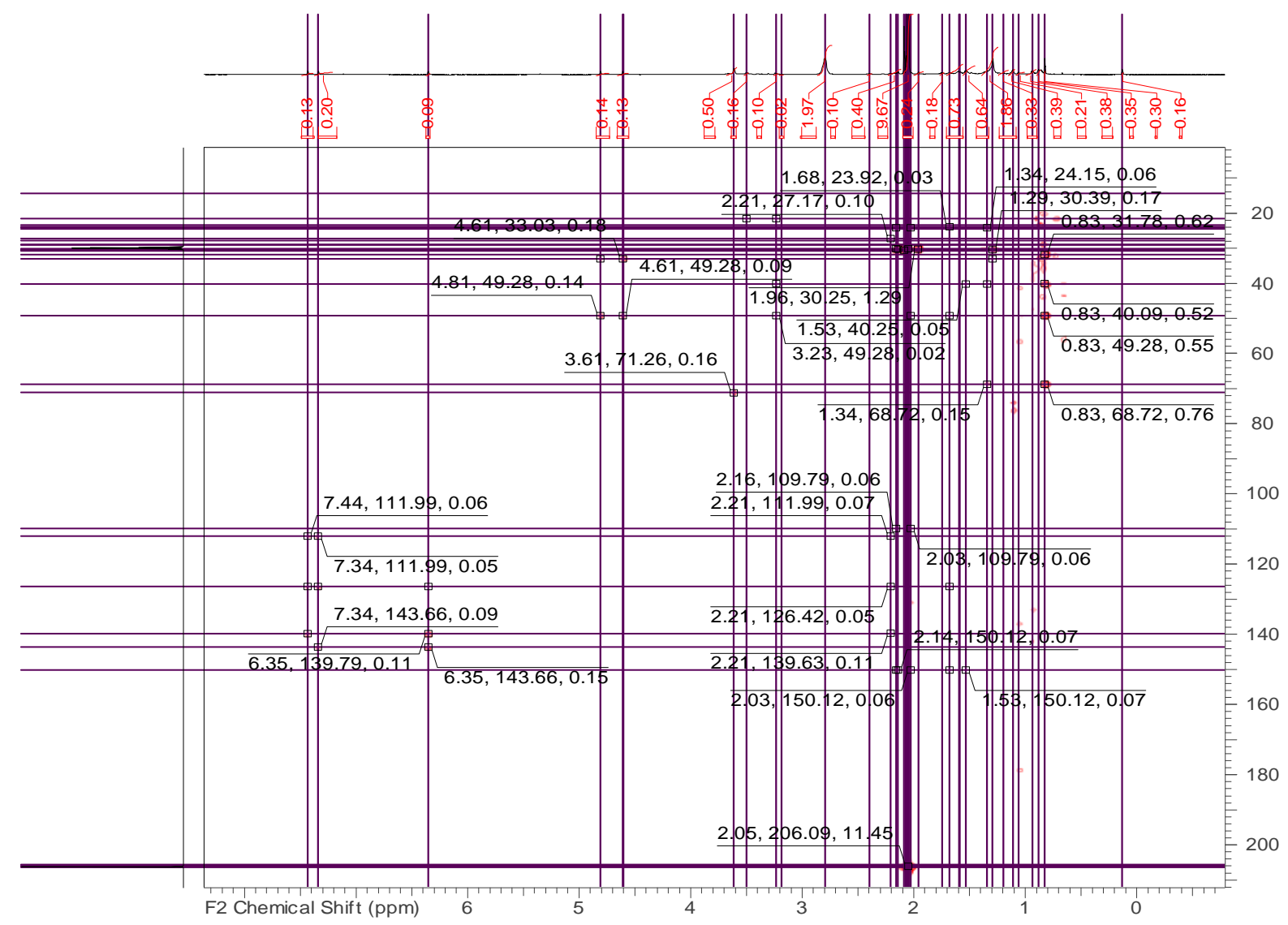


Figure $82:{ }^{1} \mathrm{H},{ }^{1} \mathrm{H}$ COSY NMR spectrum of elgonene I (10) in acetone- $\mathrm{d}_{6}(500 \mathrm{MHz})$

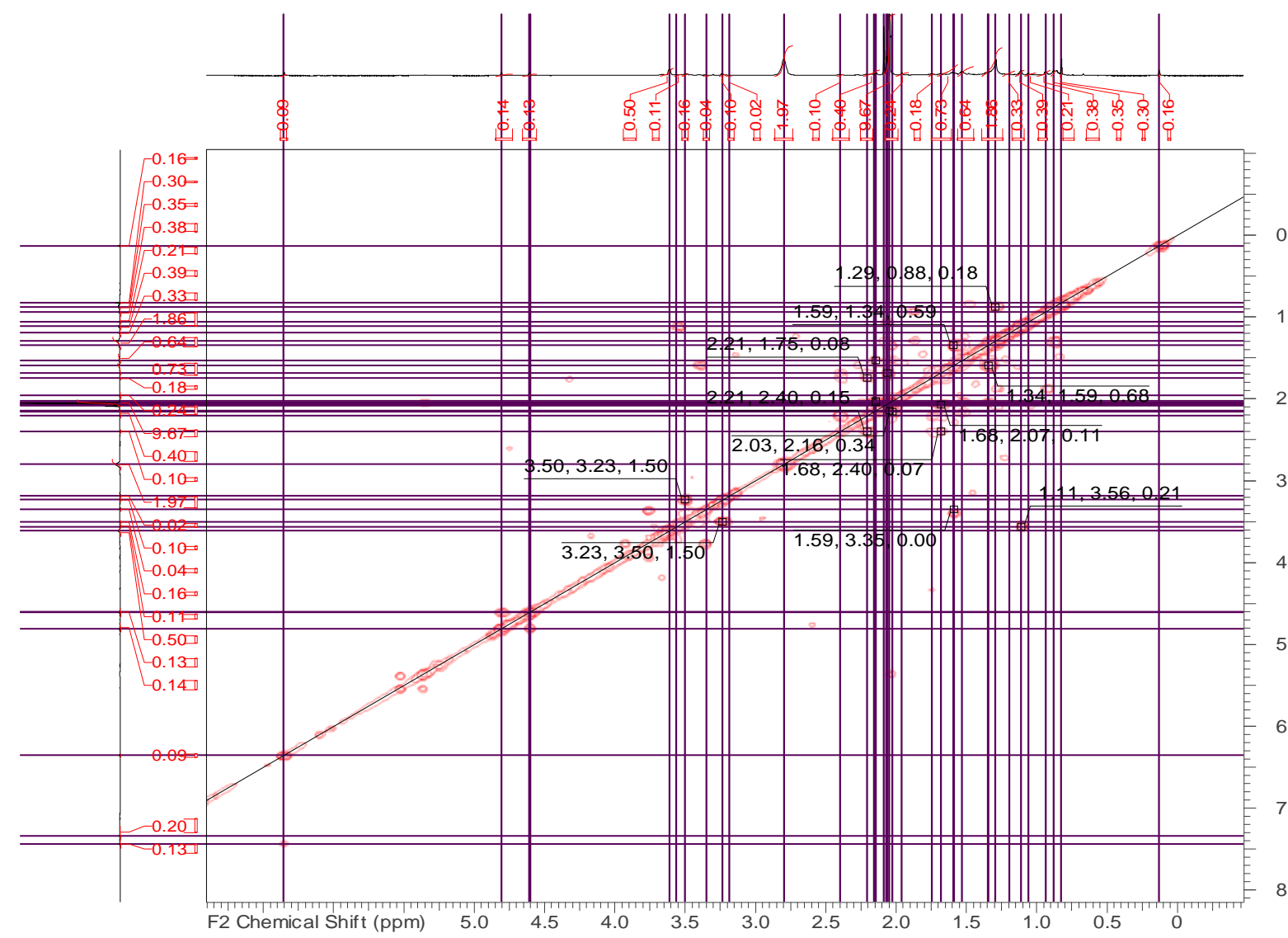

Figure 83: ${ }^{1} \mathrm{H},{ }^{1} \mathrm{H}$ ROESY NMR spectrum of elgonene I (10) in acetone- $\mathrm{d}_{6}(500 \mathrm{MHz})$

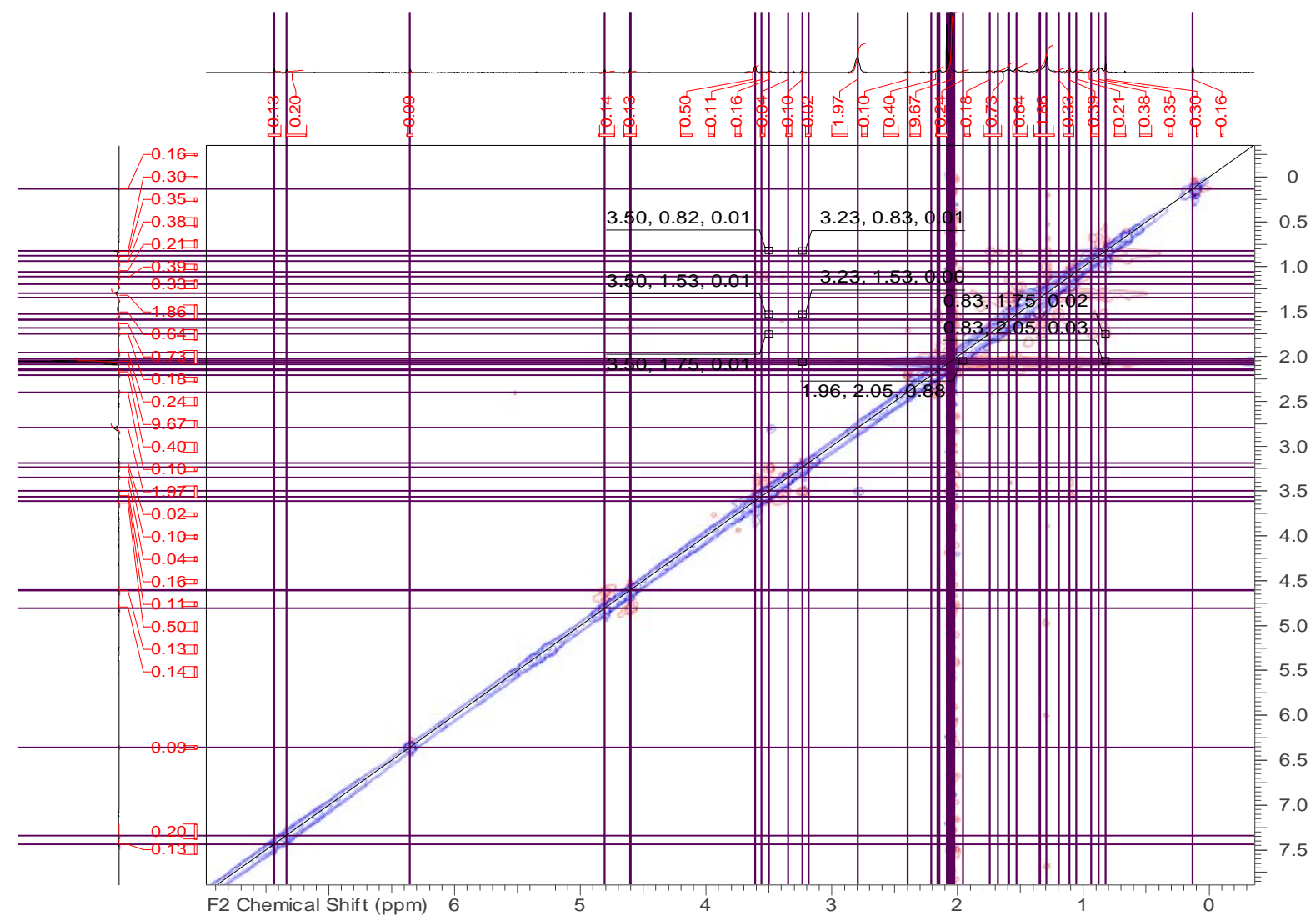


Figure 84: HR-ESIMS spectrum of elgonene I (10)
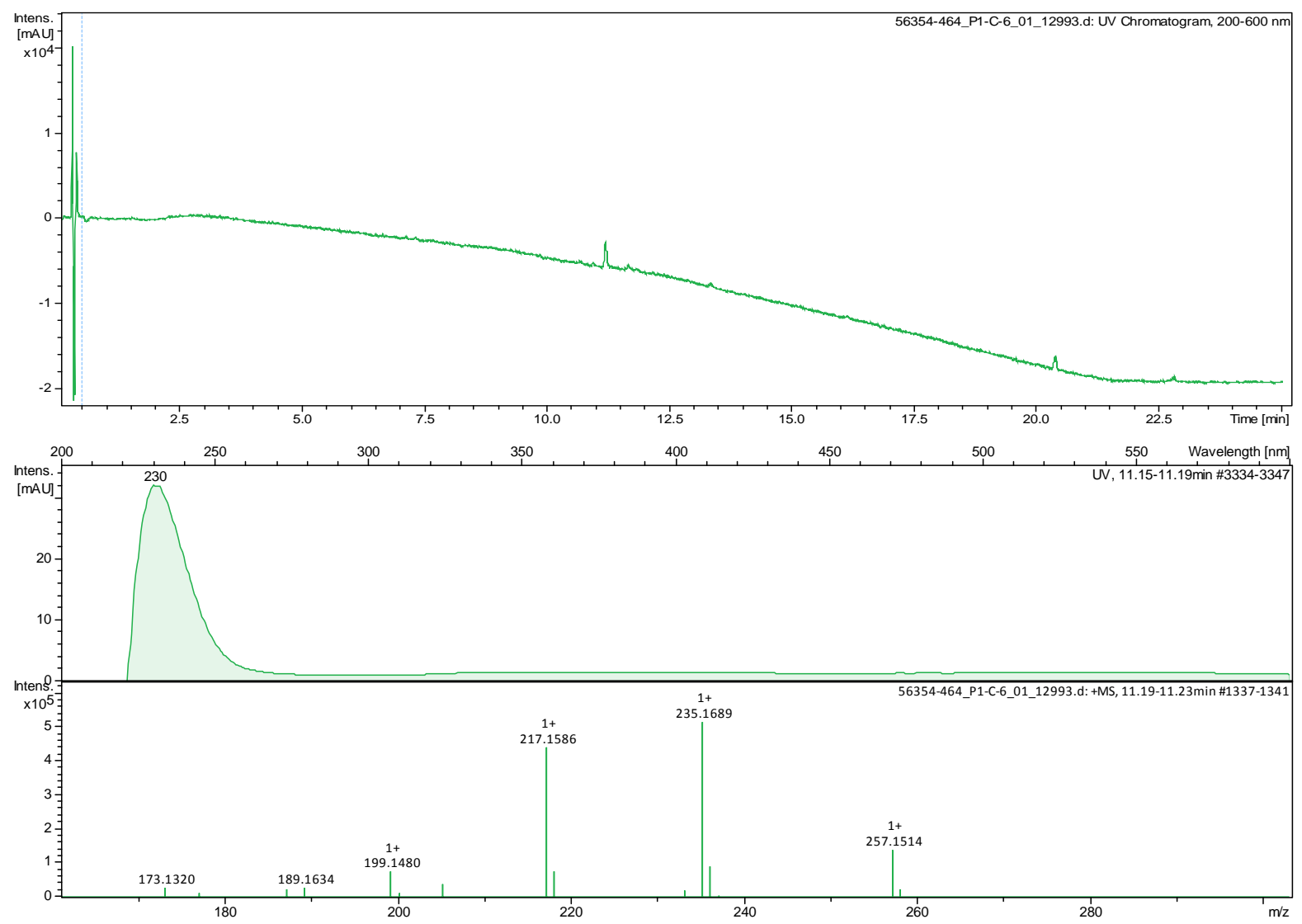

\section{1 and 2D NMR data for elgonene $J$ (11)}

Figure $85:{ }^{1} \mathrm{H}$ NMR spectrum of elgonene $\mathrm{J}(\mathbf{1 1})$ in acetone- $\mathrm{d}_{6}(700 \mathrm{MHz})$

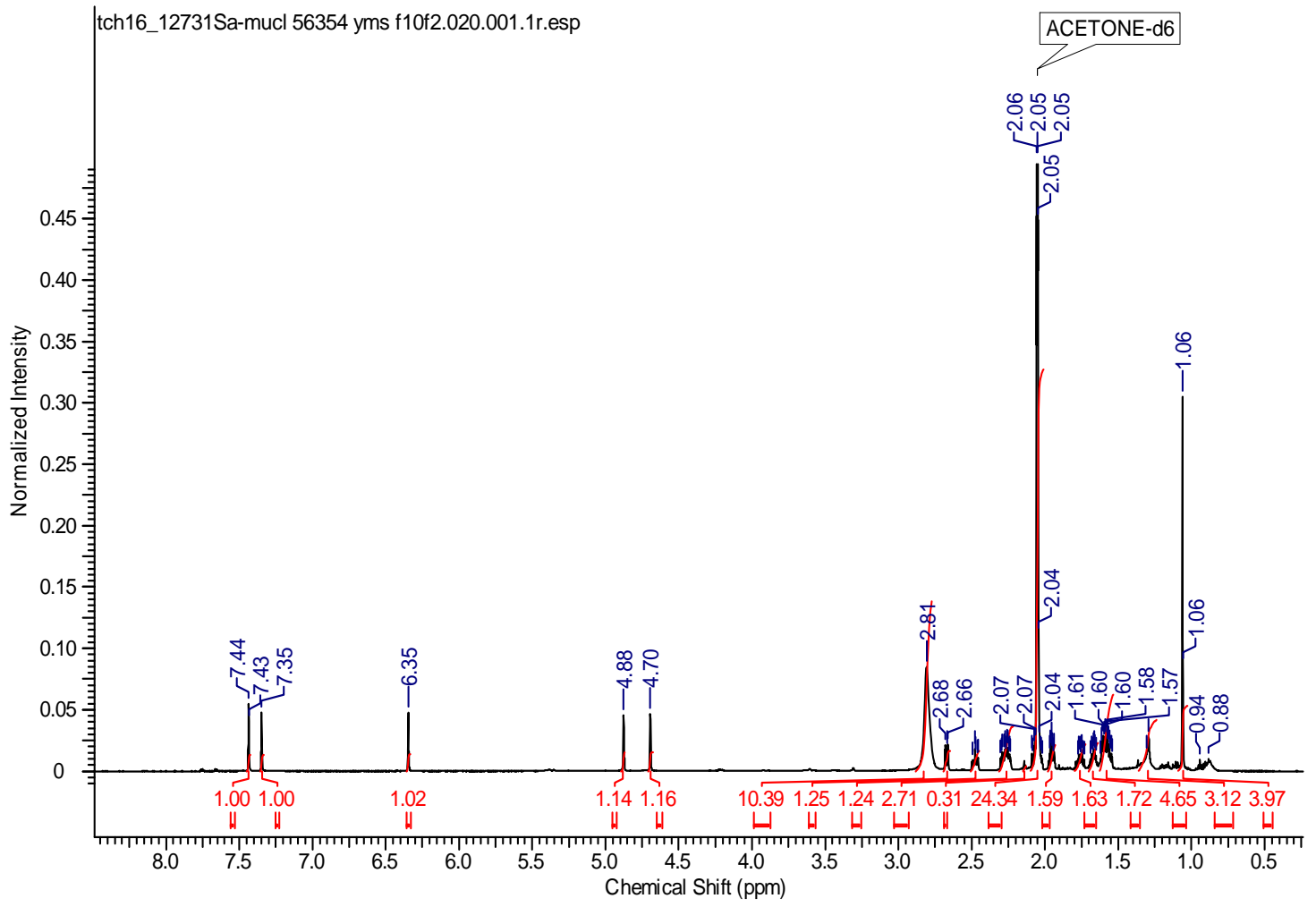


Figure $86:{ }^{13} \mathrm{C}$ NMR spectrum of elgonene $\mathrm{J}(\mathbf{1 1})$ in acetone- $\mathrm{d}_{6}(175 \mathrm{MHz})$

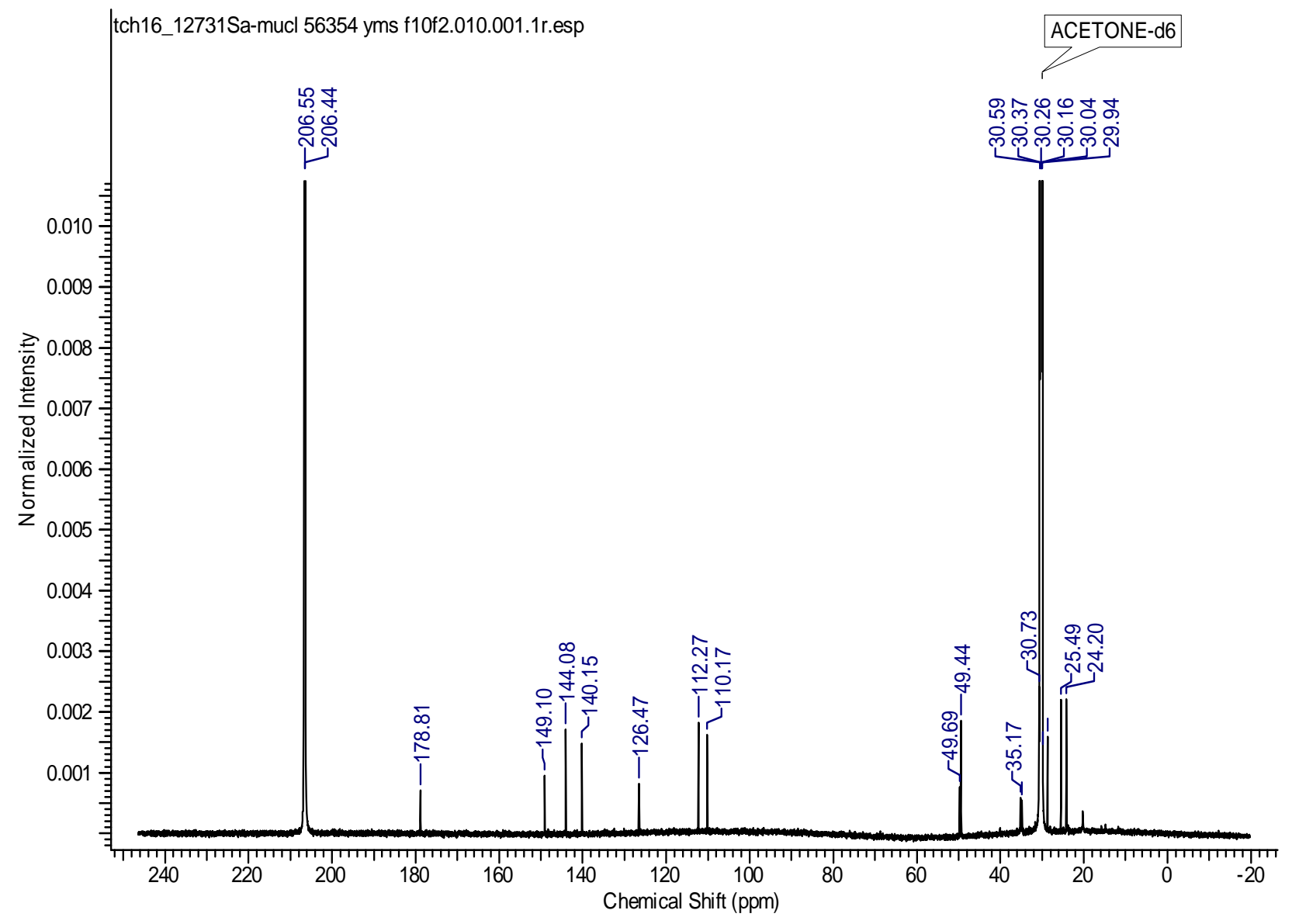

Figure 87: DEPT NMR spectrum of elgonene $\mathrm{J}(\mathbf{1 1})$ in acetone- $\mathrm{d}_{6}(175 \mathrm{MHz})$

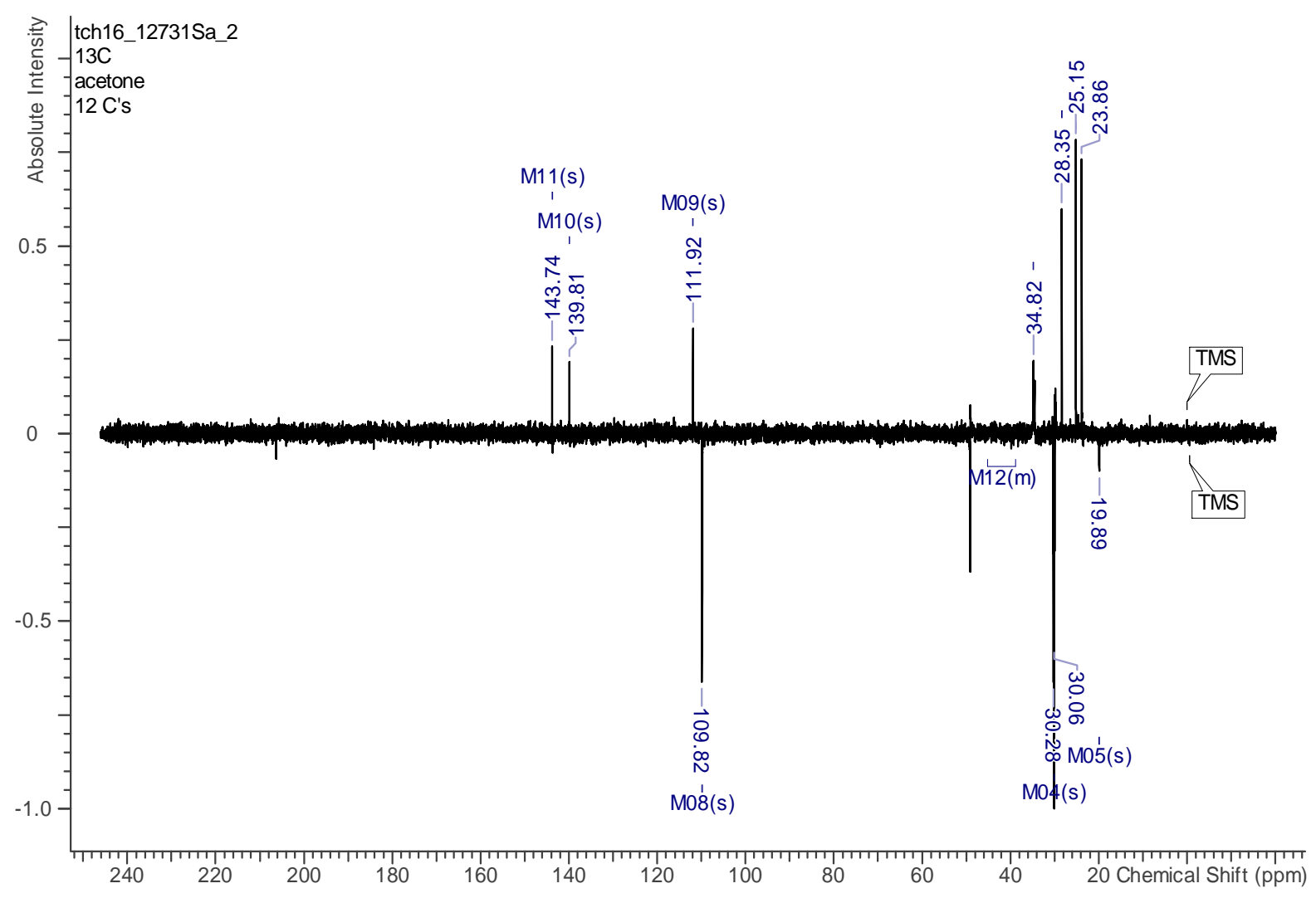


Figure 88: ${ }^{1} \mathrm{H},{ }^{13} \mathrm{C}$ HSQC NMR spectrum of elgonene $\mathrm{J}(\mathbf{1 1})$ in acetone- $\mathrm{d}_{6}(700 \mathrm{MHz}, 175$ $\mathrm{MHz}$

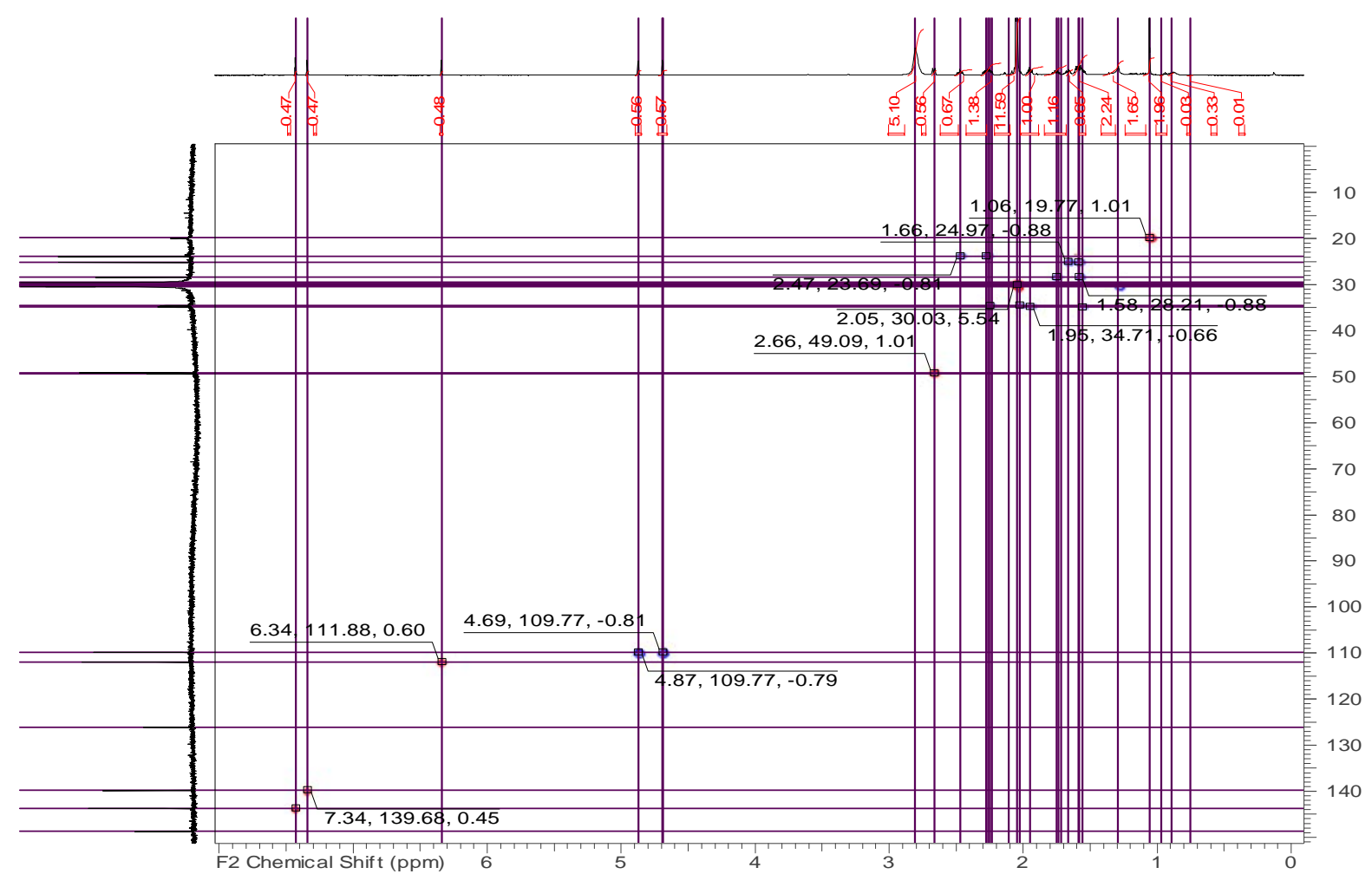

Figure 89: ${ }^{1} \mathrm{H},{ }^{13} \mathrm{C}$ HMBC NMR spectrum of elgonene $\mathrm{J}(\mathbf{1 1})$ in acetone- $\mathrm{d}_{6}(700 \mathrm{MHz}, 175$ $\mathrm{MHz})$

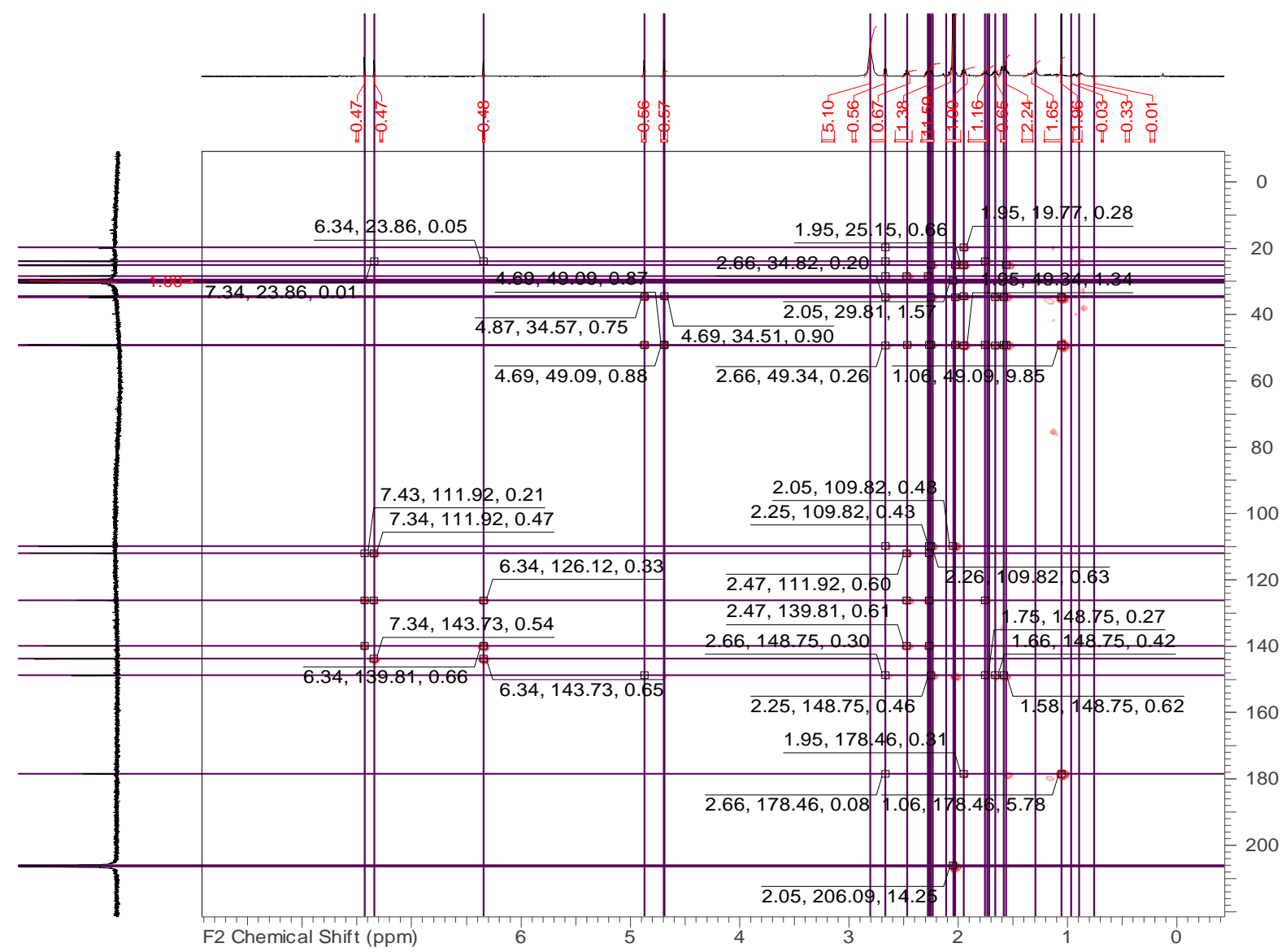


Figure 90: ${ }^{1} \mathrm{H},{ }^{1} \mathrm{H}$ COSY NMR spectrum of elgonene $\mathrm{J}(\mathbf{1 1})$ in acetone- $\mathrm{d}_{6}(700 \mathrm{MHz})$

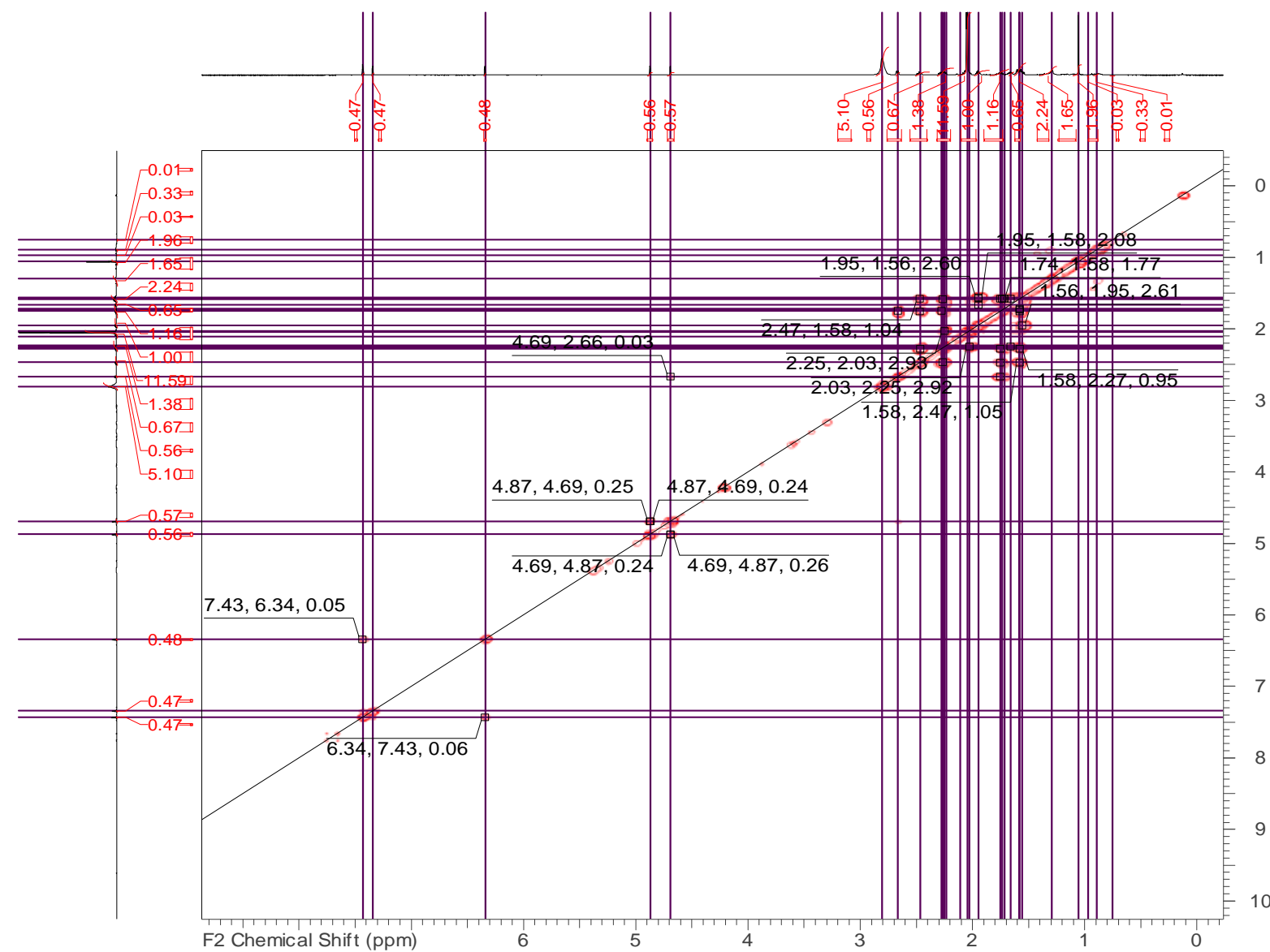

Figure 91: ${ }^{1} \mathrm{H},{ }^{1} \mathrm{H}$ ROESY NMR spectrum of elgonene $\mathrm{J}(\mathbf{1 1})$ in acetone- $\mathrm{d}_{6}(700 \mathrm{MHz})$

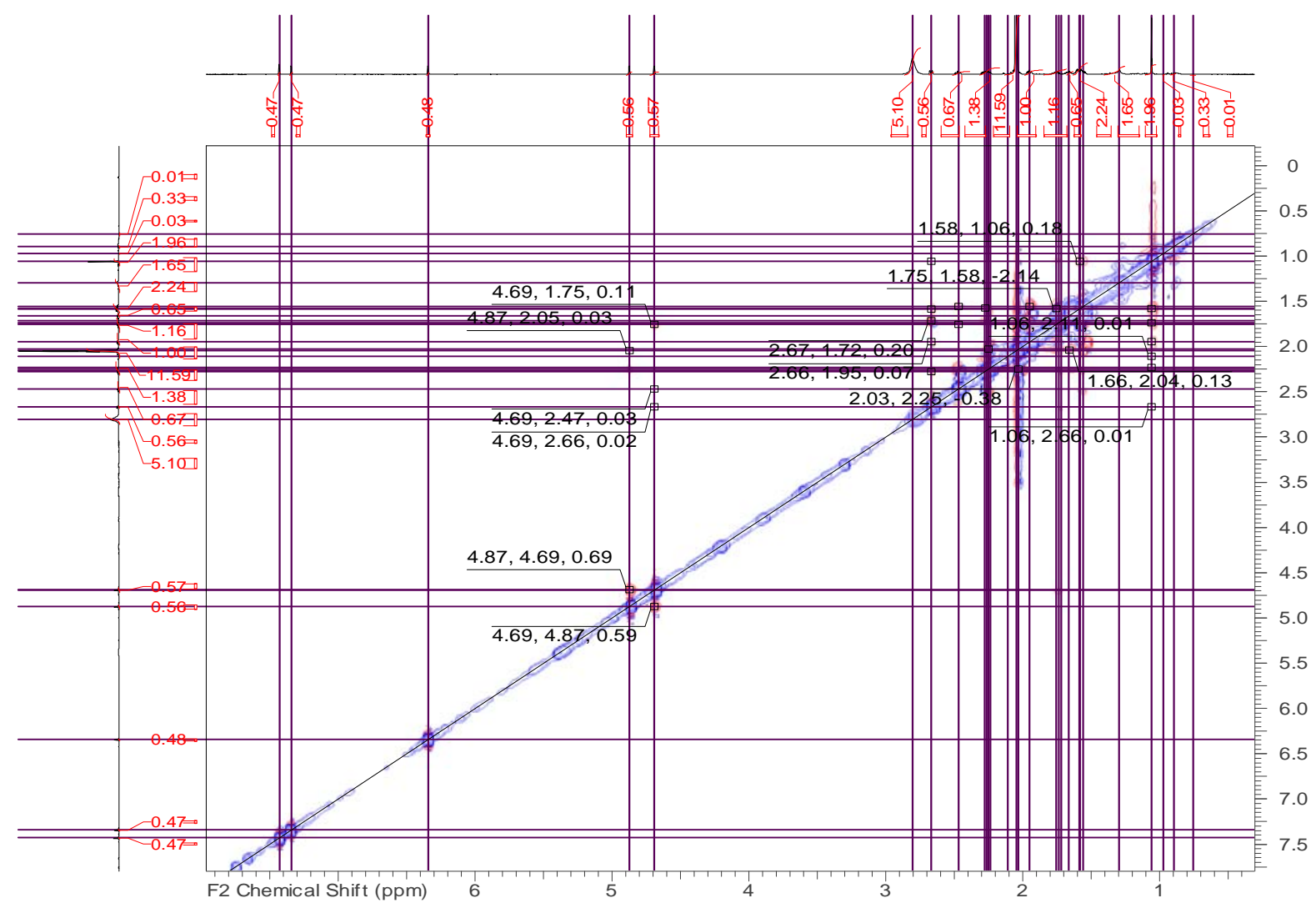


Figure 92: HR-ESIMS spectrum of elgonene J (11)

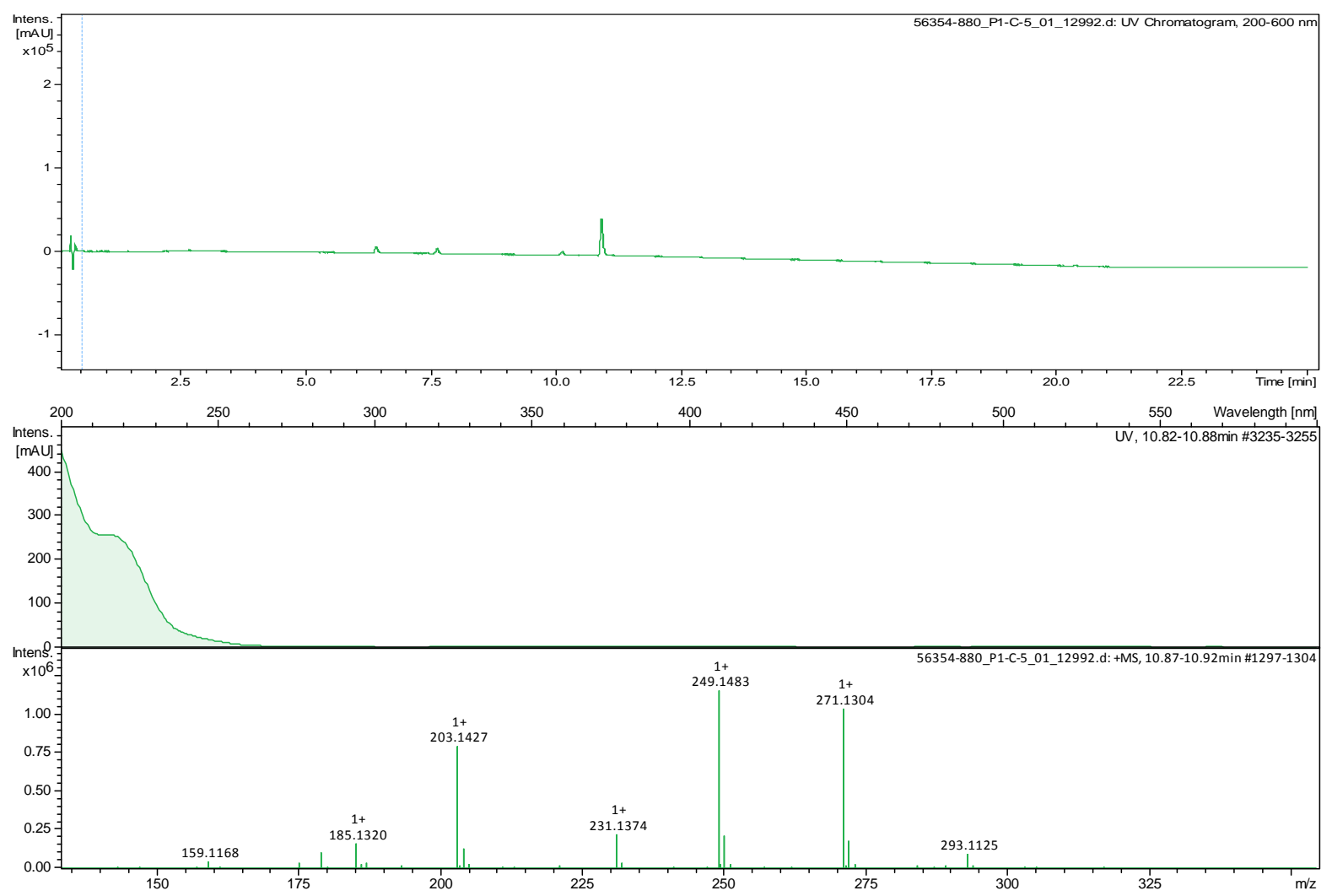

\section{1 and 2D NMR data for elgonene $K$ (12)}

Figure 93: ${ }^{1} \mathrm{H}$ NMR spectrum of elgonene $\mathrm{K}(\mathbf{1 2})$ in $\mathrm{CDCl}_{3}(500 \mathrm{MHz})$

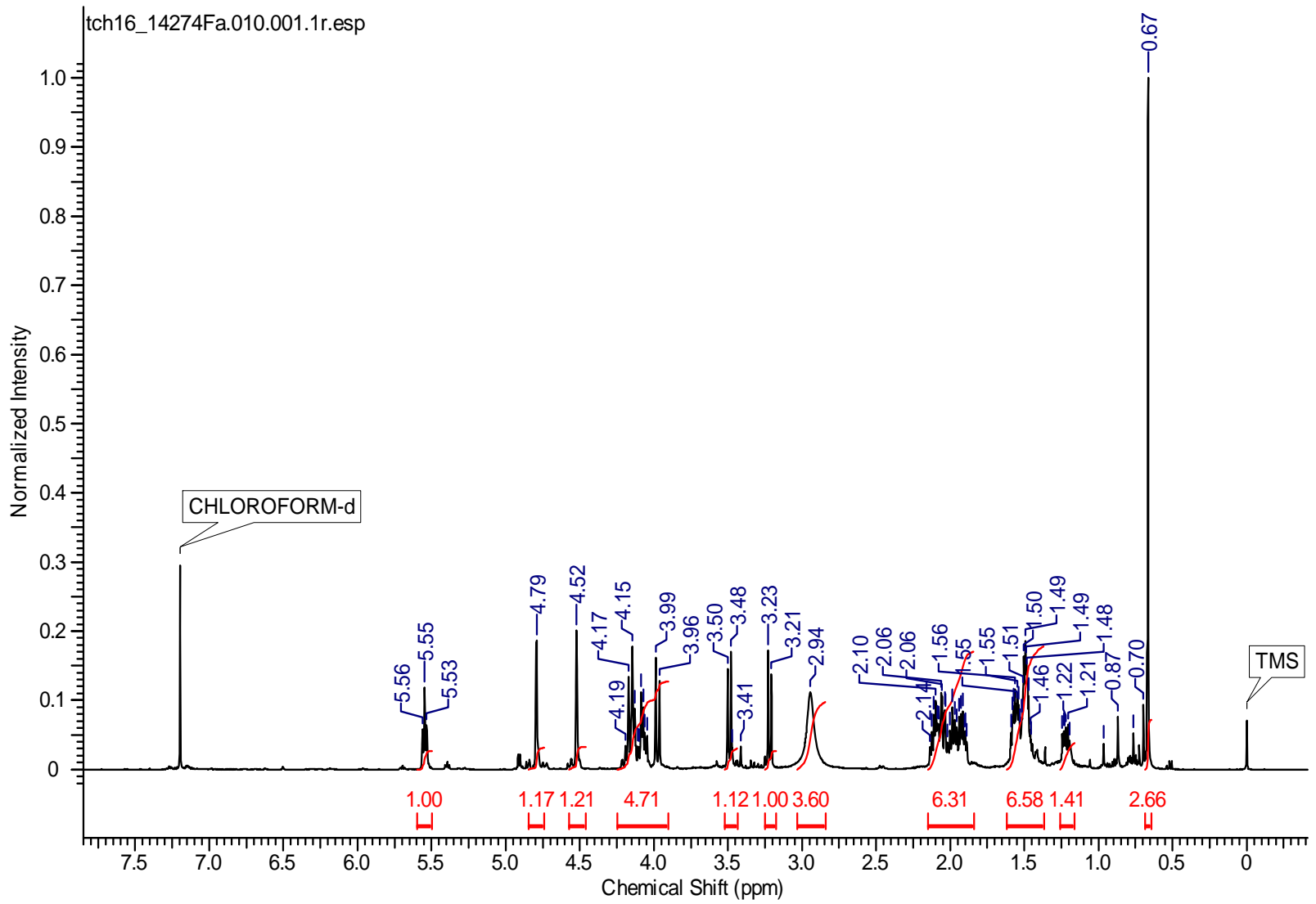


Figure 94: ${ }^{13} \mathrm{C}$ NMR spectrum of elgonene $\mathrm{K}(12)$ in $\mathrm{CDCl}_{3}(125 \mathrm{MHz})$

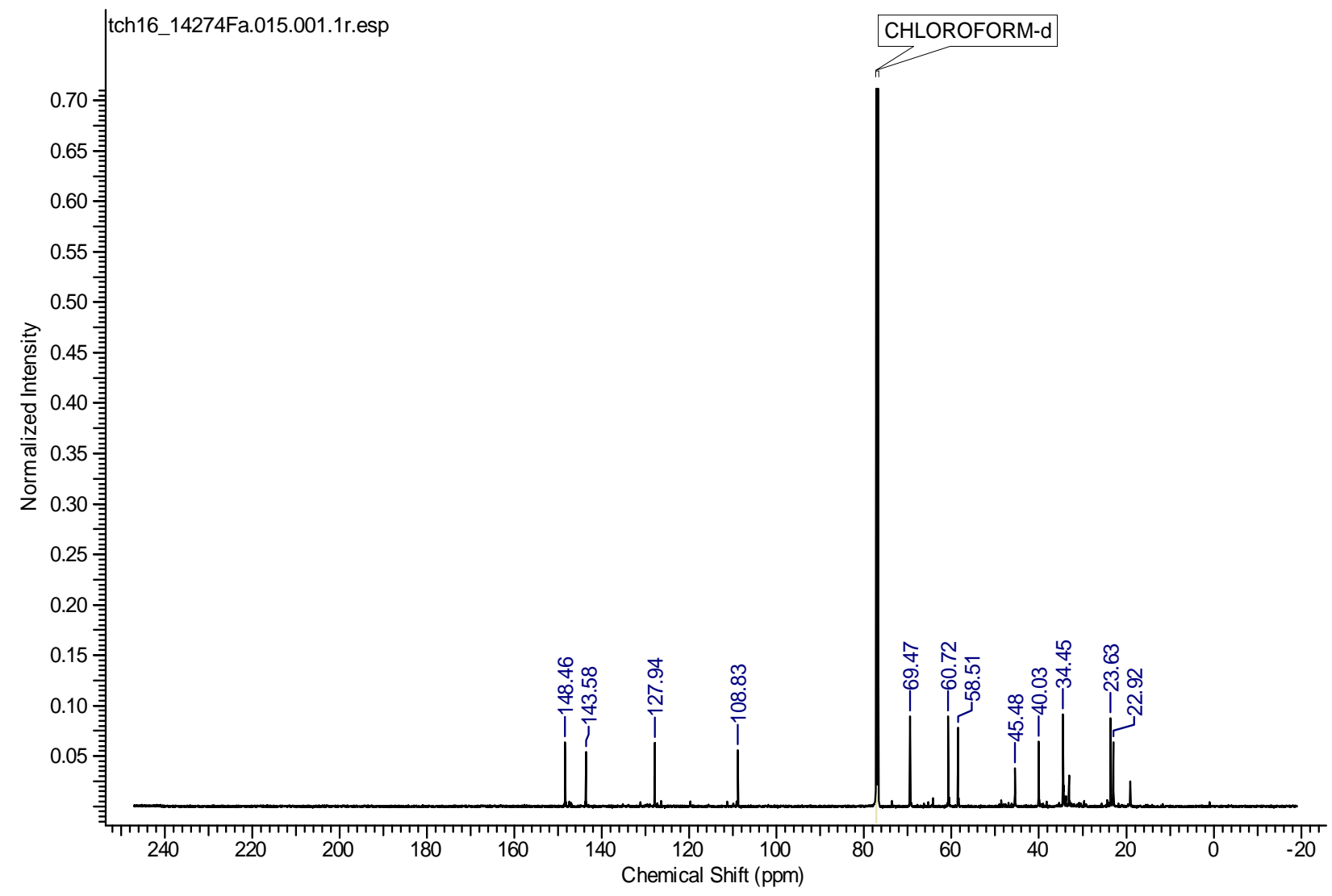

Figure 95: DEPT NMR spectrum of elgonene $\mathrm{K}(\mathbf{1 2})$ in $\mathrm{CDCl}_{3}(125 \mathrm{MHz})$

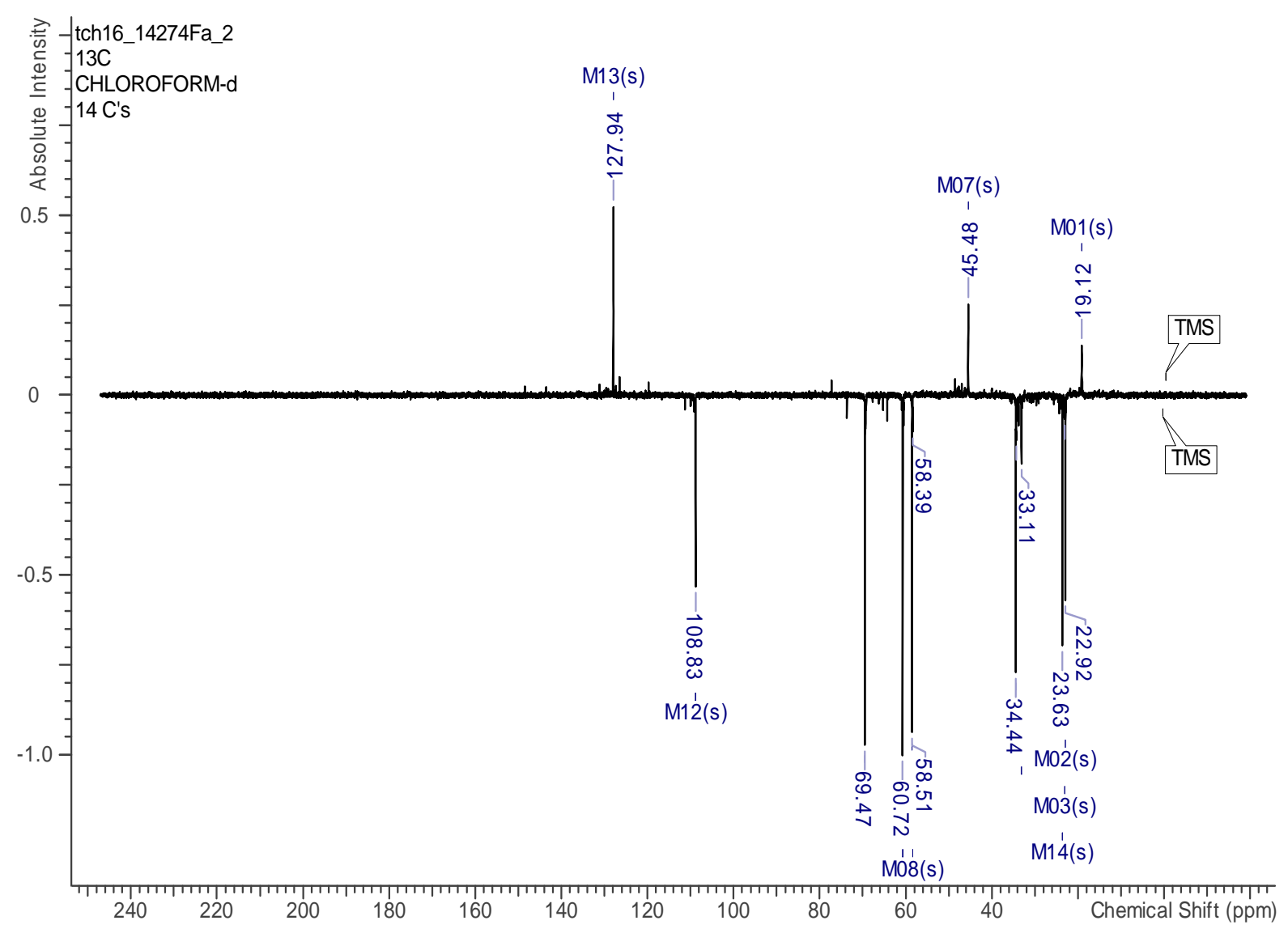


Figure 96: ${ }^{1} \mathrm{H},{ }^{13} \mathrm{C}$ HSQC NMR spectrum of elgonene $\mathrm{K}(12)$ in $\mathrm{CDCl}_{3}(500 \mathrm{MHz}, 125 \mathrm{MHz})$

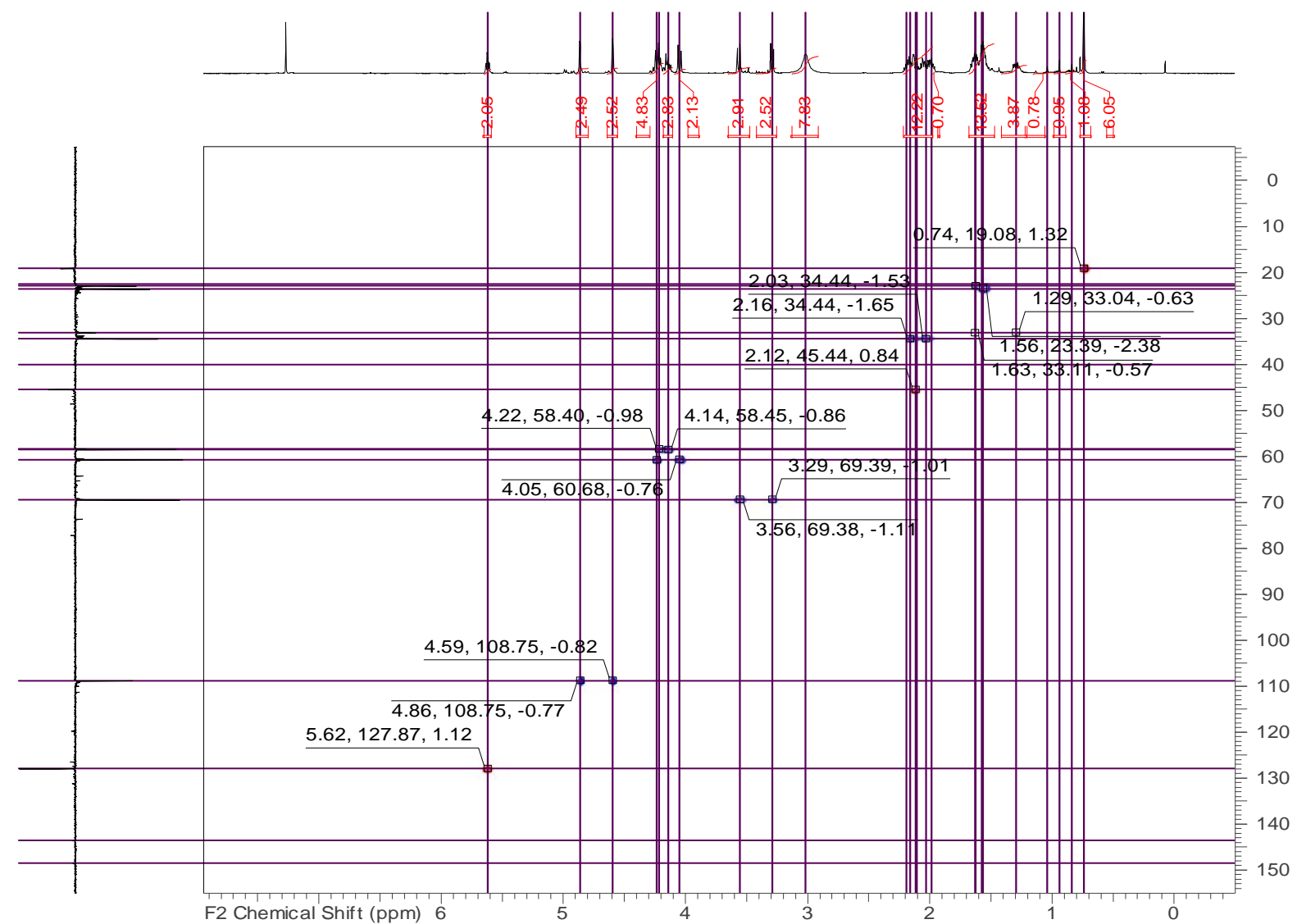

Figure 97: ${ }^{1} \mathrm{H},{ }^{13} \mathrm{C}$ HMBC NMR spectrum of elgonene $\mathrm{K}(\mathbf{1 2})$ in $\mathrm{CDCl}_{3}(500 \mathrm{MHz}, 125 \mathrm{MHz})$

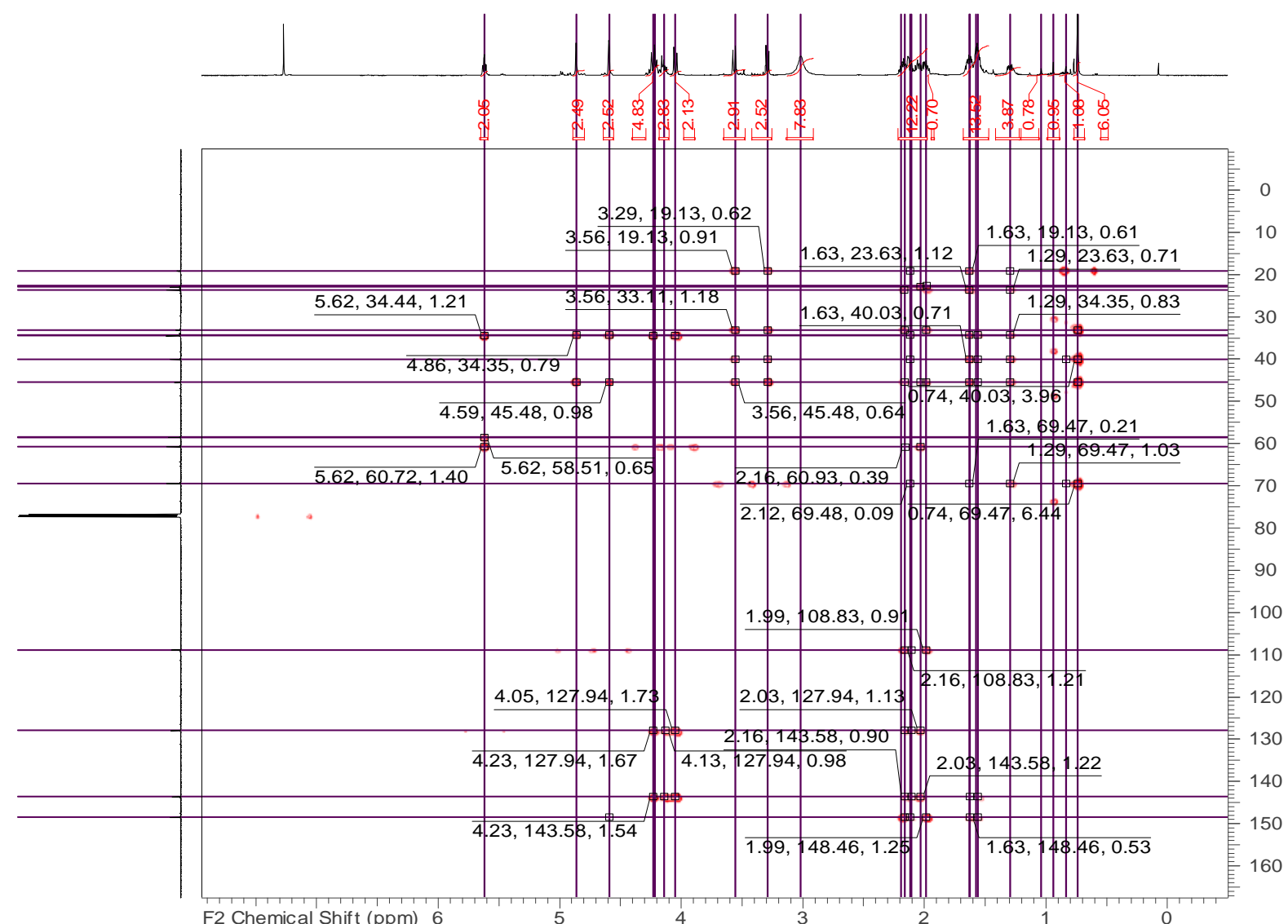


Figure 98: ${ }^{1} \mathrm{H},{ }^{1} \mathrm{H}$ COSY NMR spectrum of elgonene $\mathrm{K}(\mathbf{1 2})$ in $\mathrm{CDCl}_{3}(500 \mathrm{MHz})$

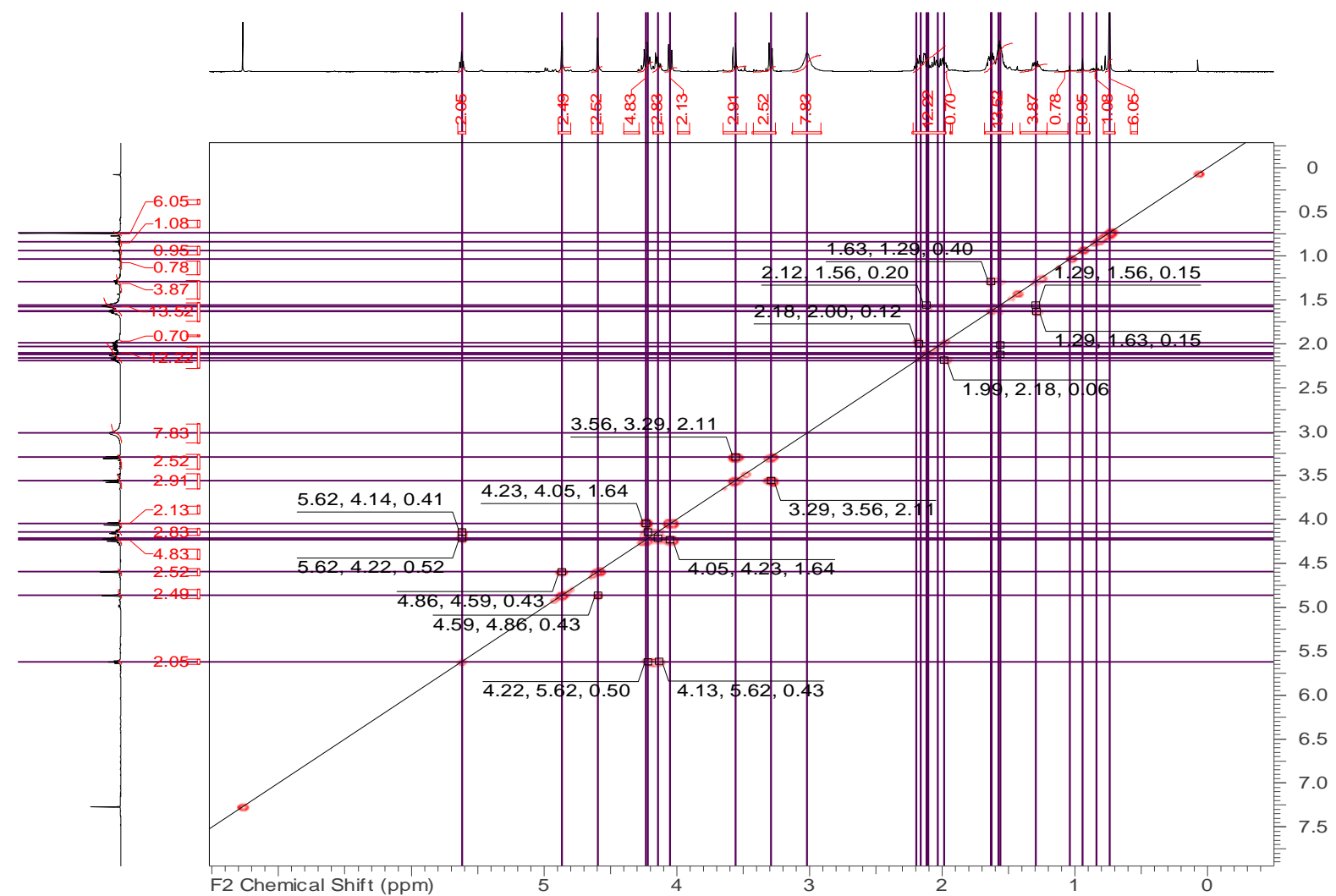

Figure 99: ${ }^{1} \mathrm{H},{ }^{1} \mathrm{H}$ ROESY NMR spectrum of elgonene $\mathrm{K}(\mathbf{1 2})$ in $\mathrm{CDCl}_{3}(500 \mathrm{MHz})$

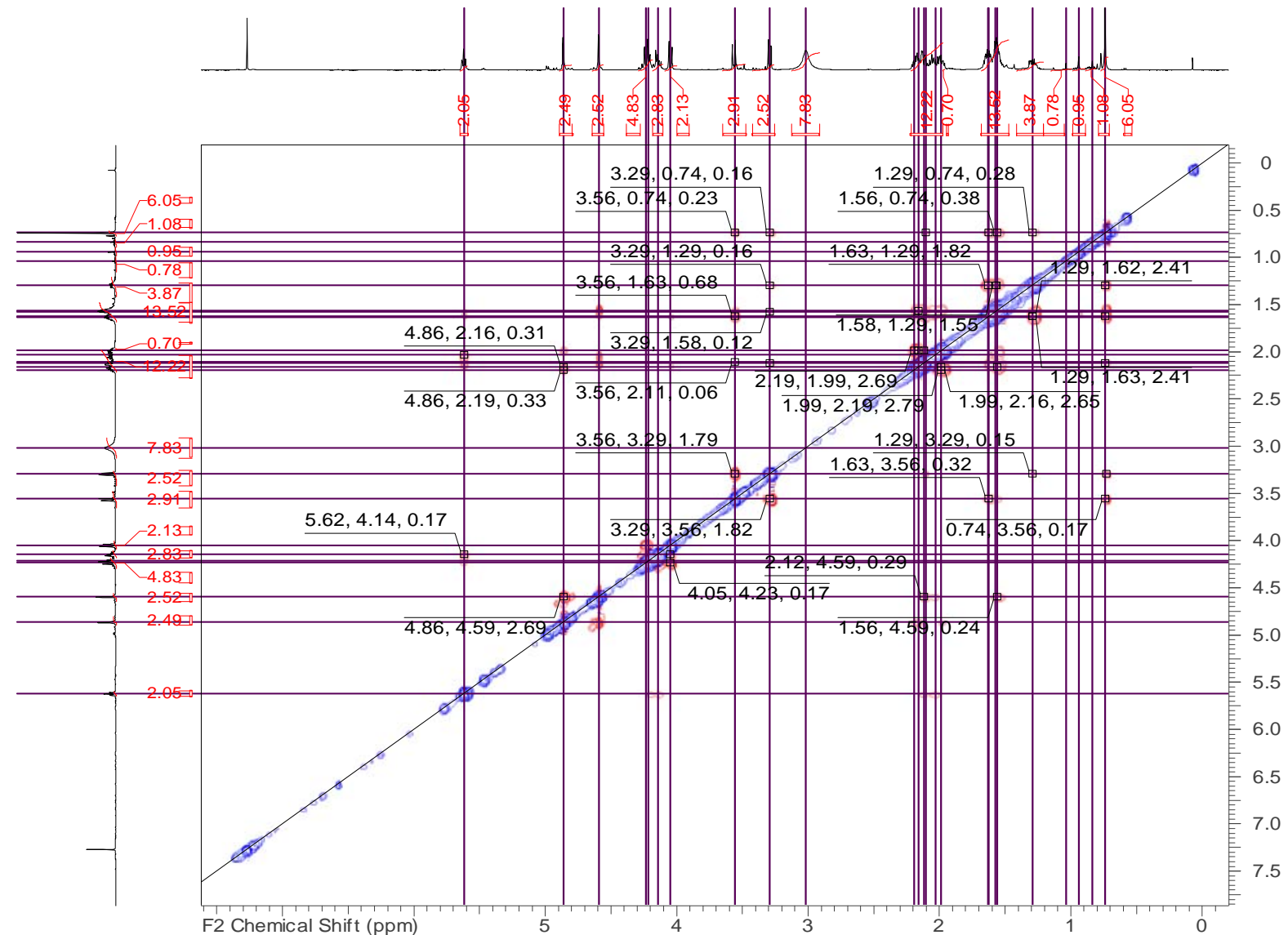


Figure 100: HR-ESIMS spectrum of elgonene K (12)

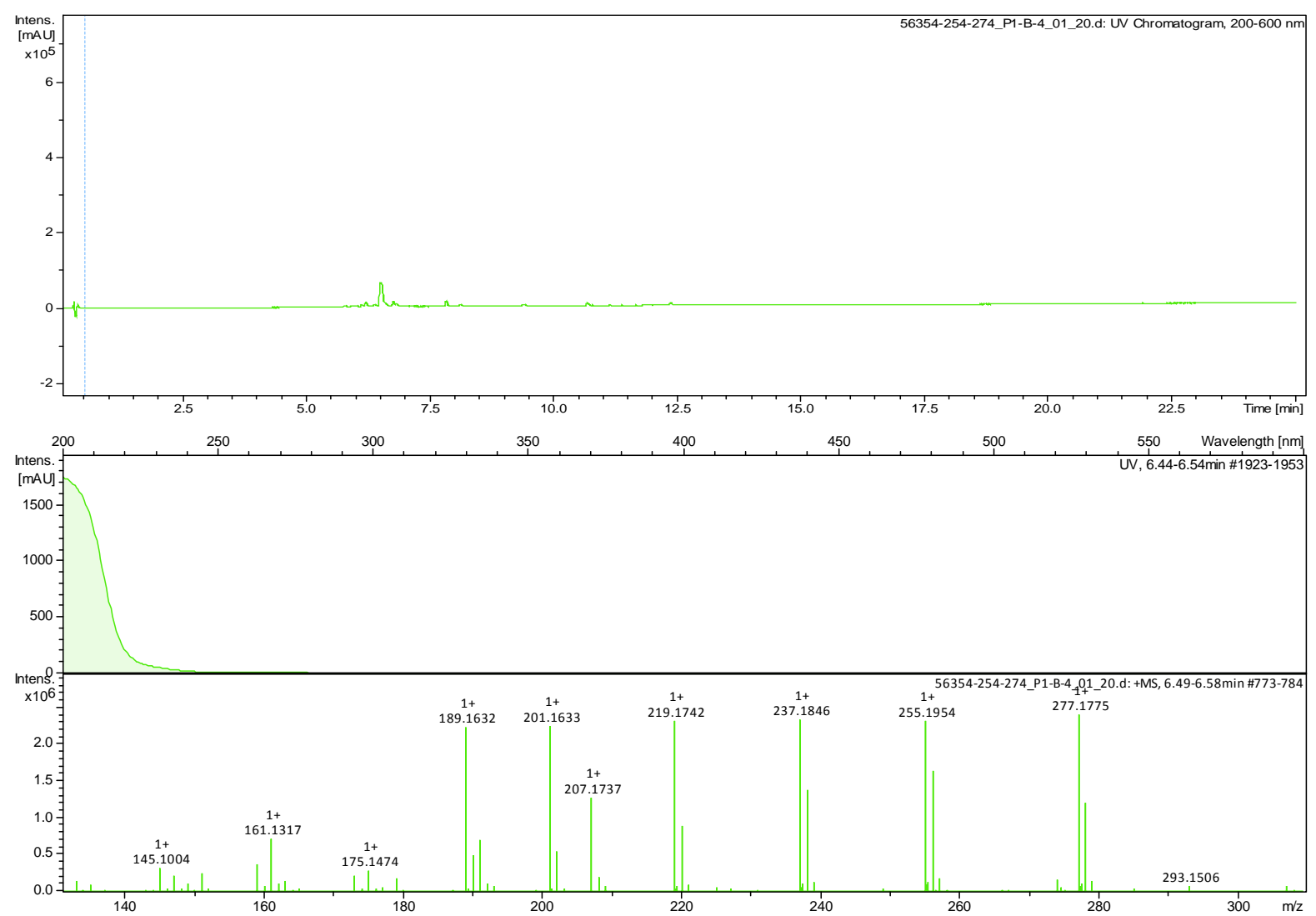

\section{1 and 2D NMR data for elgonene $L$ (13)}

Figure 101: ${ }^{1} \mathrm{H}$ NMR spectrum of elgonene $\mathrm{L}(\mathbf{1 3})$ in $\mathrm{CDCl}_{3}(700 \mathrm{MHz})$

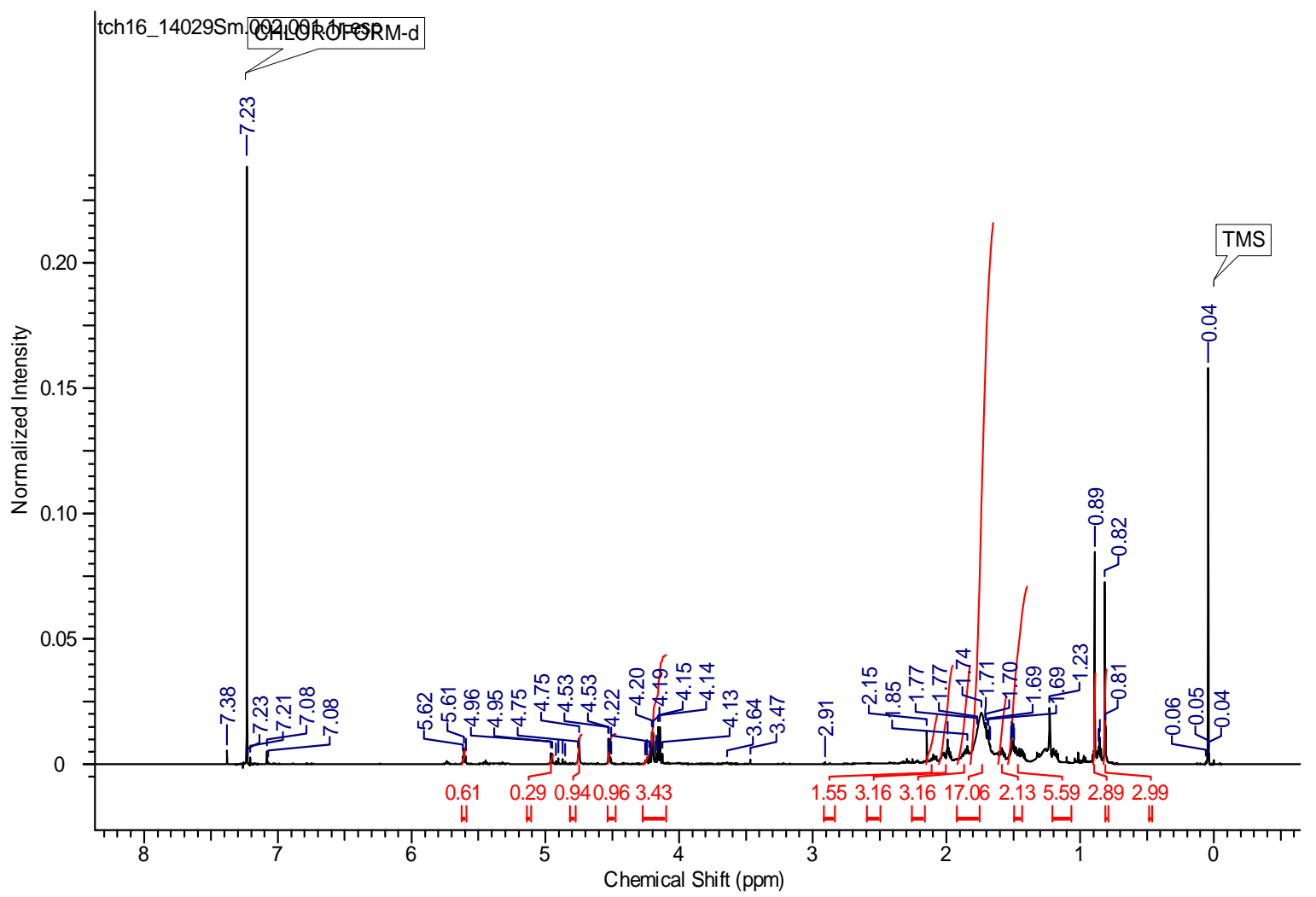


Figure 102: ${ }^{13} \mathrm{C}$ NMR spectrum of elgonene $\mathrm{L}(\mathbf{1 3})$ in $\mathrm{CDCl}_{3}(175 \mathrm{MHz})$

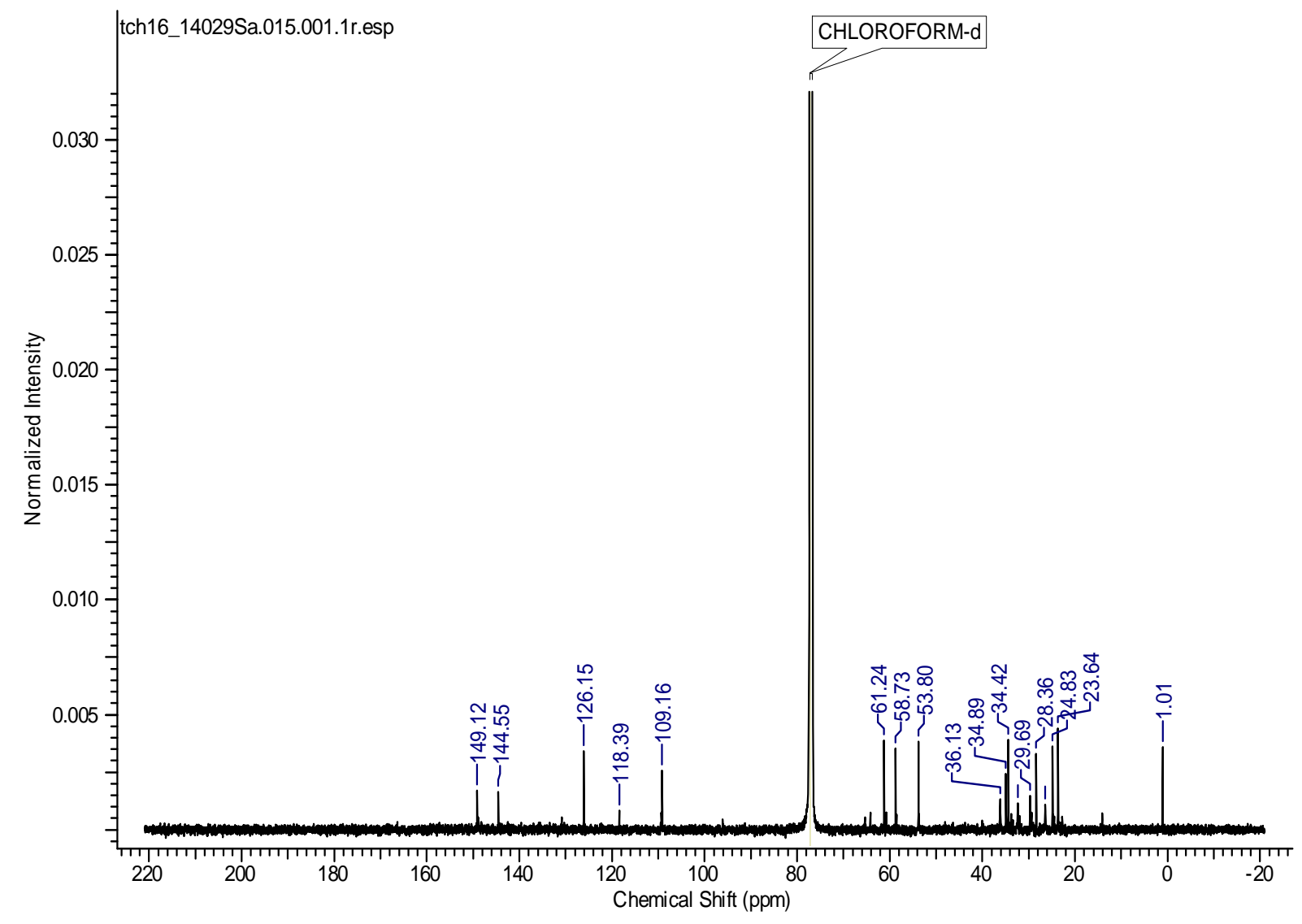

Figure 103: DEPTNMR spectrum of elgonene $\mathrm{L}(\mathbf{1 3})$ in $\mathrm{CDCl}_{3}(175 \mathrm{MHz})$

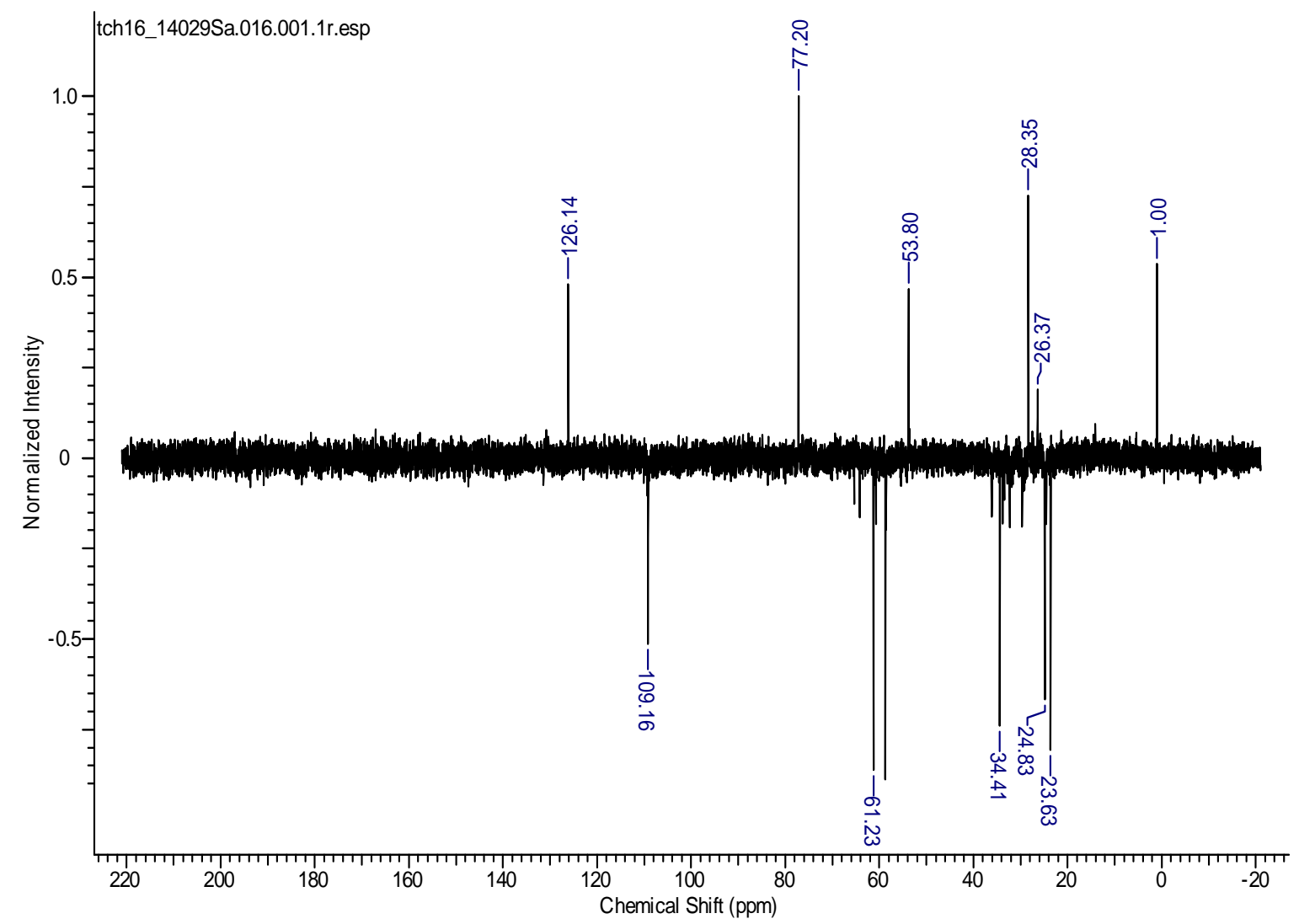


Figure 104: ${ }^{1} \mathrm{H},{ }^{13} \mathrm{C}$ HSQC NMR spectrum of elgonene L (13) in $\mathrm{CDCl}_{3}(700 \mathrm{MHz}, 175 \mathrm{MHz})$

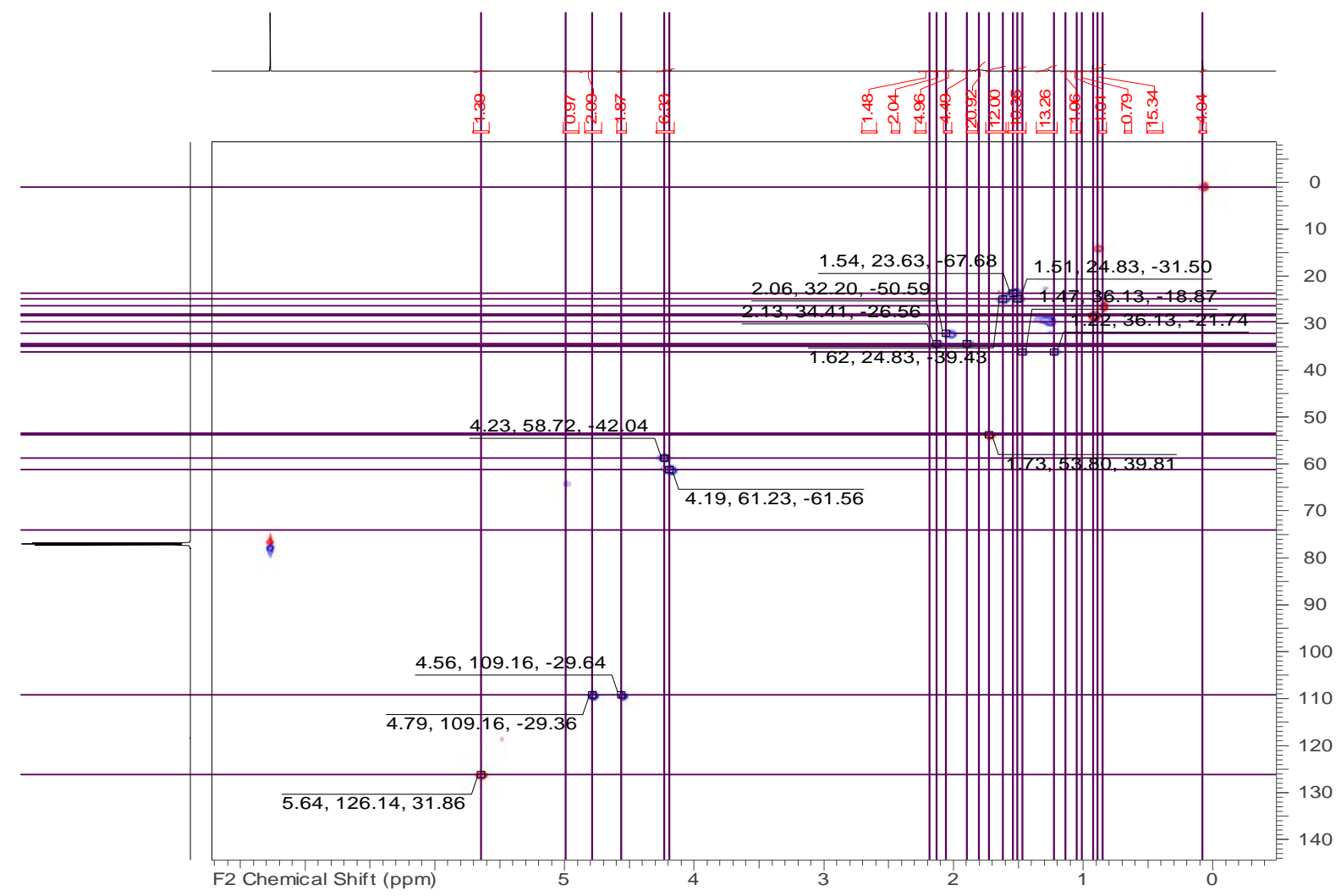

Figure 105: ${ }^{1} \mathrm{H},{ }^{13} \mathrm{C}$ HMBC NMR spectrum of elgonene L (13) in $\mathrm{CDCl}_{3}(700 \mathrm{MHz}, 175 \mathrm{MHz})$

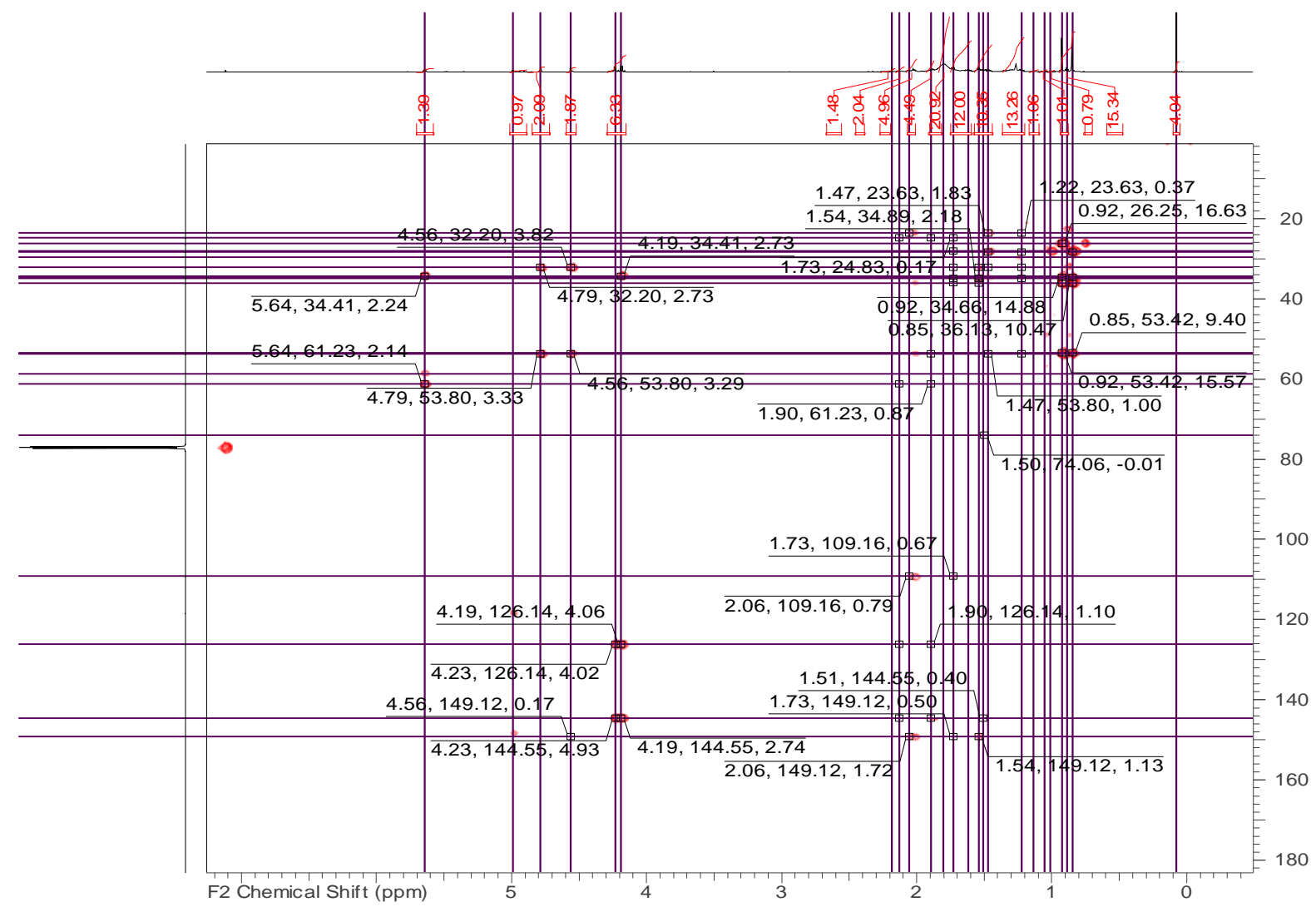


Figure 106: ${ }^{1} \mathrm{H},{ }^{1} \mathrm{H}$ COSY NMR spectrum of elgonene $\mathrm{L}(\mathbf{1 3})$ in $\mathrm{CDCl}_{3}(700 \mathrm{MHz})$

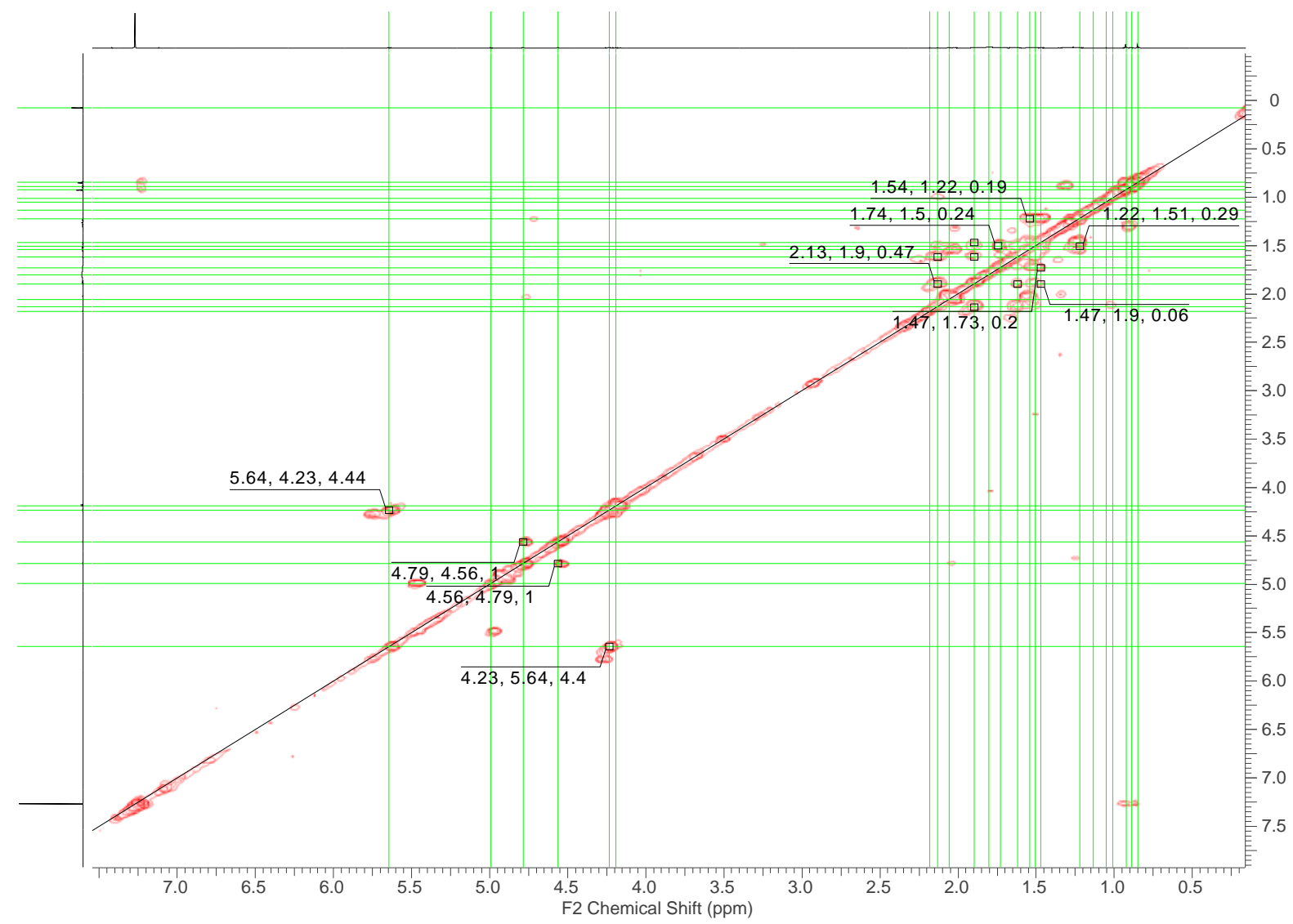

Figure 107: ${ }^{1} \mathrm{H},{ }^{1} \mathrm{H}$ ROESY NMR spectrum of elgonene $\mathrm{L}(\mathbf{1 3})$ in $\mathrm{CDCl}_{3}(700 \mathrm{MHz})$

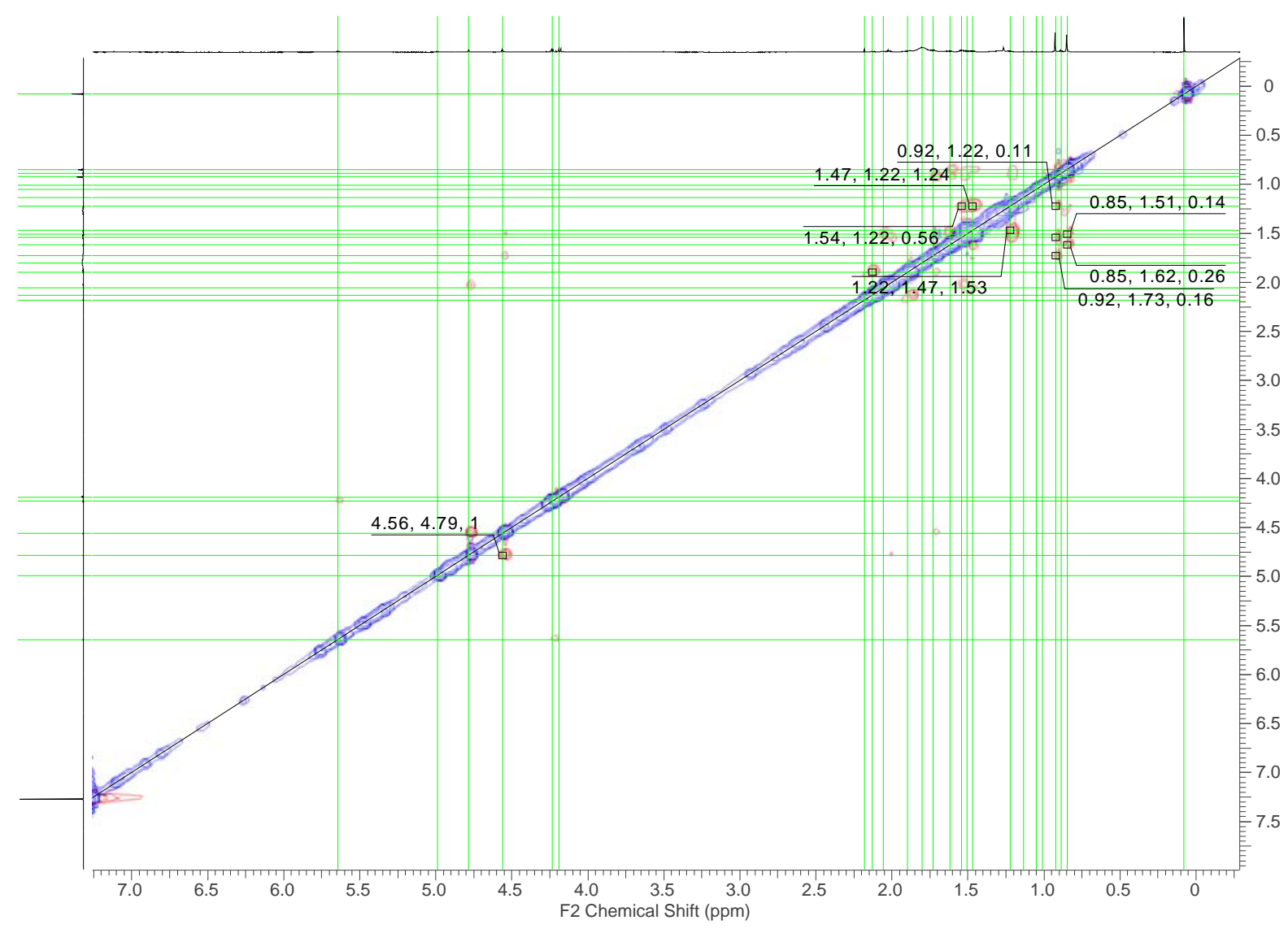


Figure 108: HR-ESIMS spectrum of elgonene L (13)

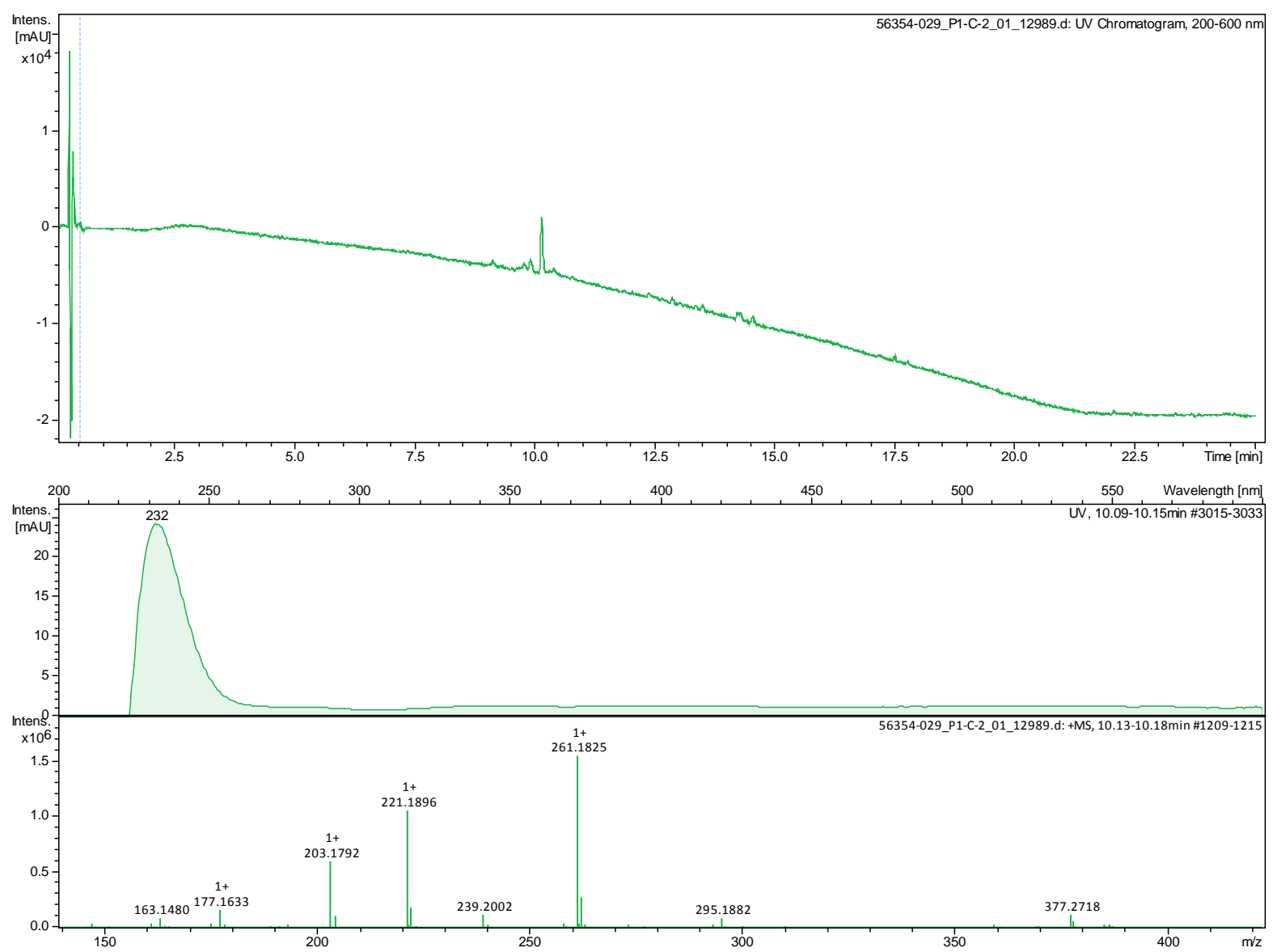

NMR data of $(6 R, 7 S, 10 R)-7,10$-epoxy-7,11-dimethyldodec-1-ene-6,11-diol (1), (S)MTPA ester

${ }^{1} \mathrm{H}$ NMR (700 MHz, Pyridine-d $\left.\mathrm{d}_{5}\right), 7.43$ (3H, m) , 7.59 (2H, m), 6.45 (1H, dd, J=17.42, 10.97 Hz), 5.54 (1H, dd, J=9.46, $2.15 \mathrm{~Hz}), 5.36$ (1H, d, $J=17.64), 5.09$ (1H, d, $J=10.97), 4.01(1 \mathrm{H}, \mathrm{t}$, $\mathrm{J}=7.10 \mathrm{~Hz}), 2.476(2 \mathrm{H}, \mathrm{m}), 2.43(1 \mathrm{H}, \mathrm{m}), 2.27(1 \mathrm{H}, \mathrm{m}), 2.19(1 \mathrm{H}, \mathrm{m}) 1.99(1 \mathrm{H}, \mathrm{m}), 1.98(1 \mathrm{H}$, m), $1.93(1 \mathrm{H}, \mathrm{m}), 1.62(1 \mathrm{H}, \mathrm{m}), 1.41(3 \mathrm{H}, \mathrm{s}), 1.33(3 \mathrm{H}, \mathrm{s}), 1.23(3 \mathrm{H}, \mathrm{s})$.

NMR data of $(6 R, 7 S, 10 R)-7,10-e p o x y-7,11$-dimethyldodec-1-ene-6,11-diol (1), (S)MTPA ester

${ }^{1} \mathrm{H}$ NMR (700 MHz, Pyridine-d $\left.\mathrm{d}_{5}\right), 7.43$ (3H, m) , 7.60 (2H, m), 6.41 (1H, dd, J=17.42, 10.97 Hz), 5.54 (1H, dd, J=9.90, 2.37 Hz), 5.24 (1H, d, J=17.42), 5.08 (1H, d, J=10.97), 4.02 (1H, dd, J=4.04, $4.02 \mathrm{~Hz}), 2.36(2 \mathrm{H}, \mathrm{m}), 2.36(1 \mathrm{H}, \mathrm{m}), 2.19(1 \mathrm{H}, \mathrm{m}), 2.22(1 \mathrm{H}, \mathrm{m}), 2.11(1 \mathrm{H}, \mathrm{m})$, 1.95(1H, m), $1.89(1 \mathrm{H}, \mathrm{m}), 1.73(1 \mathrm{H}, \mathrm{m}), 1.43(3 \mathrm{H}, \mathrm{s}), 1.33(3 \mathrm{H}, \mathrm{s}), 1.25(3 \mathrm{H}, \mathrm{s})$. 
Table 1: Compound (1) (R) and (S)- MTPA esters data analysis

\begin{tabular}{|l|l|l|l|}
\hline & $S$-MTPA ester & $R$-MTPA & $\Delta \delta S R=S$-MTPA- $R$-MTPA \\
\hline $8 \mathrm{a}$ & 1.616 & 1.733 & -0.117 \\
\hline $8 \mathrm{~b}$ & 1.998 & 2.108 & -0.110 \\
\hline $9 \mathrm{a}$ & 1.932 & 1.945 & -0.013 \\
\hline $9 \mathrm{~b}$ & 2.194 & 2.221 & -0.027 \\
\hline 10 & 4.008 & 4.021 & -0.013 \\
\hline 12 & 1.234 & 1.311 & -0.077 \\
\hline 13 & 1.409 & 1.427 & -0.018 \\
\hline 14 & 1.325 & 1.333 & -0.008 \\
\hline 2 & 6.445 & 6.409 & +0.036 \\
\hline $1 \mathrm{~b}$ & 5.357 & 5.241 & +0.116 \\
\hline $1 \mathrm{a}$ & 5.094 & 5.085 & +0.009 \\
\hline $5 \mathrm{~b}$ & 2.433 & 2.368 & +0.065 \\
\hline $5 \mathrm{a}$ & 1.984 & 1.894 & +0.009 \\
\hline $4 \mathrm{~b}$ & 2.476 & 2.358 & +0.118 \\
\hline $4 \mathrm{a}$ & 2.274 & 2.188 & +0.086 \\
\hline
\end{tabular}

\section{NMR data of Elgonene A (2) (S)- MTPA ester}

${ }^{1} \mathrm{H}$ NMR (700 MHz, Pyridine-d $\left.\mathrm{d}_{5}\right), 7.45$ (3H, m) , 7.60 (2H, m), 7.24 (1H, m), 6.10 (1H, d, $J=3.0 \mathrm{~Hz}), 5.48(1 \mathrm{H}, \mathrm{m}), 5.40(1 \mathrm{H}, \mathrm{m}), 5.18(1 \mathrm{H}, \mathrm{s}), 5.12(1 \mathrm{H}, \mathrm{s}), 3.84\left(3 \mathrm{H}, \mathrm{OCH}_{3}\right), 2.32(1 \mathrm{H}$, m), $2.08(1 \mathrm{H}, \mathrm{m}), 2.05(1 \mathrm{H}, \mathrm{m}), 1.97(1 \mathrm{H}, \mathrm{m}), 1.94(1 \mathrm{H}, \mathrm{m}), 1.86(3 \mathrm{H}, \mathrm{s}), 1.60(1 \mathrm{H}, \mathrm{m}), 1.50$ $(1 \mathrm{H}, \mathrm{m}), 1.61(3 \mathrm{H}, \mathrm{s})$.

\section{NMR data of Elgonene A (2) (R)- MTPA ester}

${ }^{1} \mathrm{H}$ NMR (700 MHz, Pyridine-d $)$ ), 7.43 (3H, m), 7.60 (2H, m), 7.24 (1H, m), 6.17 (1H, d, $J=3.23 \mathrm{~Hz}), 5.40(1 \mathrm{H}, \mathrm{m}), 5.40(1 \mathrm{H}, \mathrm{m}), 5.39(1 \mathrm{H}, \mathrm{s}), 5.30(1 \mathrm{H}, \mathrm{s}), 3.45\left(3 \mathrm{H}, \mathrm{OCH}_{3}\right), 2.33(1 \mathrm{H}$, m), $2.13(1 \mathrm{H}, \mathrm{m}), 2.09(1 \mathrm{H}, \mathrm{m}), 1.97(1 \mathrm{H}, \mathrm{m}), 1.94(1 \mathrm{H}, \mathrm{m}), 1.82(3 \mathrm{H}, \mathrm{s}), 1.61(1 \mathrm{H}, \mathrm{m}), 1.51$ $(1 \mathrm{H}, \mathrm{m}), 1.61(3 \mathrm{H}, \mathrm{s})$. 
Table 2: Elgonene A (2) $(R)$ and (S)-MTPA esters data analysis

\begin{tabular}{|l|l|l|l|}
\hline & $S$-MTPA ester & $R$-MTPA ester & $\Delta \delta S R=S$-MTPA-R-MTPA \\
\hline 4 & 5.401 & 5.404 & -0.003 \\
\hline $5 \mathrm{a}$ & 2.077 & 2.126 & -0.049 \\
\hline $5 \mathrm{~b}$ & 1.602 & 1.604 & -0.002 \\
\hline 6 & 2.316 & 2.334 & -0.018 \\
\hline 14 & 5.116 & 5.295 & -0.179 \\
& 5.180 & 5.387 & -0.207 \\
\hline 9 & 5.476 & 5.418 & +0.058 \\
\hline 10 & 7.239 & 7.237 & +0.002 \\
\hline 15 & 1.862 & 1.818 & +0.044 \\
\hline
\end{tabular}

\section{NMR data of Elgonene D (5) (S)- MTPA ester}

${ }^{1} \mathrm{H}$ NMR (700 MHz, Pyridine-d 5 ), 7.43 (3H, m), 7.60 (2H, m), 6.52 (1H, m), 5.47 (1H, m), $4.62(1 \mathrm{H}, \mathrm{dd}, J=5.65,12.82 \mathrm{~Hz}), 3.85\left(3 \mathrm{H}, \mathrm{OCH}_{3}\right), 2.68(1 \mathrm{H}, \mathrm{m}), 2.46(1 \mathrm{H}, \mathrm{m}), 2.44(1 \mathrm{H}, \mathrm{m})$, $2.40(1 \mathrm{H}, \mathrm{m}), 2.29(1 \mathrm{H}, \mathrm{m}), 2.26(1 \mathrm{H}, \mathrm{m}), 2.09(1 \mathrm{H}, \mathrm{m}), 1.96(1 \mathrm{H}, \mathrm{m}), 1.65(1 \mathrm{H}, \mathrm{m}), 1.94$ $(3 \mathrm{H}, \mathrm{s}), 1.64(3 \mathrm{H}, \mathrm{s}), 1.43(3 \mathrm{H}, \mathrm{s})$.

\section{NMR data of Elgonene D (5) (R)- MTPA ester}

${ }^{1} \mathrm{H}$ NMR (700 MHz, Pyridine-d $\left.\mathrm{d}_{5}\right), 7.43$ (3H, m), 7.60 (2H, m), $6.53(1 \mathrm{H}, \mathrm{m}), 5.47(1 \mathrm{H}, \mathrm{m})$, $4.62(1 \mathrm{H}, \mathrm{dd}, J=3.66,12.69 \mathrm{~Hz}), 3.45\left(3 \mathrm{H}, \mathrm{OCH}_{3}\right), 2.69(1 \mathrm{H}, \mathrm{m}), 2.50(1 \mathrm{H}, \mathrm{m}), 2.47(1 \mathrm{H}, \mathrm{m})$, $2.42(1 \mathrm{H}, \mathrm{m}), 2.29(1 \mathrm{H}, \mathrm{m}), 2.25(1 \mathrm{H}, \mathrm{m}), 2.03(1 \mathrm{H}, \mathrm{m}), 1.95(1 \mathrm{H}, \mathrm{m}), 1.64(1 \mathrm{H}, \mathrm{m}), 1.94$ $(3 \mathrm{H}, \mathrm{s}), 1.65(3 \mathrm{H}, \mathrm{s}), 1.43(3 \mathrm{H}, \mathrm{s})$.

Table 3: Elgonene D (5) (R) and (S)-MTPA esters data analysis

\begin{tabular}{|l|l|l|l|}
\hline & $S$-MTPA ester & $R$-MTPA ester & $\Delta \delta S R=S$-MTPA- $R$-MTPA \\
\hline 4 & 2.461 & 2.466 & -0.005 \\
& 2.682 & 2.690 & -0.008 \\
\hline 3 & 6.524 & 6.530 & -0.006 \\
\hline 14 & 1.435 & 1.432 & +0.003 \\
\hline 7 & 2.262 & 2.250 & +0.012 \\
\hline 8 & 1.645 & 1.643 & +0.002 \\
& 1.955 & 1.950 & +0.005 \\
\hline 11 & 5.467 & 5.465 & +0.002 \\
\hline 12 & 2.093 & 2.034 & +0.059 \\
& 2.440 & 2.420 & +0.02 \\
\hline
\end{tabular}


ITS nrDNA sequence of MUCL56354

$>$ MUCL56354

GACTGCGGAAGGATTATCGAGCTTTTTGAAAGCGAGACTTGTTGCTGGCGCGTGG AAACGCGCATGTGCACGGTTTTCGCGCTCAAATCCATCTCTTTAAACCCCCGCCTT AACCCGGCCAAAGTTAGTAGTCTTTTTGGGGTTTGTTGGTTTGTAGTAAATCAGTA GAAAGGTGAAATCGGGTGAGCTTACTTACCCGGTAGTAATCTTTTGAACGTCGAA AGCAAAGGCGAAACGATCTTCTCCCTATTCCTCCGTTCGGGCGAAGGCTTTGGCT TGTGTGTGTTATTATACAAACACCTTTAATTGTCTTTGTGAATGTATTTGCTCCTTG TGGGCGAAAATAAATACAACTTTCAACAACGGATCTCTTGGCTCTCGCATCGATG AAGAACGCAGCGAAATGCGATAAGTAATGTGAATTGCAGAATTCAGTGAATCAT CGAATCTTTGAACGCACCTTGCGCCCCTTGGTATTCCGAGGGGCATGCCTGTTTGA GTGTCATGTTAATCTCAAACCGCTAGTCTTTCTTAATTGAAGGGCTTTGAGGTTTG GACTTGGAGGCTTCATTGCTGGCGTGGGGGTTCCCCTTTCGGGAGGACTTCGTCC GGCTCCTCTTAAATGCATTAGCTGGGCTTTGGCTCGCGTTTACGGTGTAATAGTTA ATTCCATTCACCAAGGAACGCTTGCCTTACGGGCCTGCTTCTAATCGTCCGCATCG TCGGACAAGGAGCTGTTGTTGCTCCTTCTTGACCCCTTTGACTCAAATCAGGTAGG ACTACCCGCTGAACTTAAGCT

An initial BLAST search of ITS nucleotide sequences from the NCBI database (http://www. ncbi. nlm. nih. gov/) gave KP030787.1 (Sanghuangporus microcystideus), the closest hit with identity 96\%, the next closest hit (JF895464.2 with 93\%) belongs to Inonotus species, The comparison of the 20 closest ITS BLAST results showed the relationship of MUCL56354, Sanghuangporus species, Inonotus species and Phellinus species (Figure 109). Based on molecular data we have addressed the strain as Sanghuangporus sp. MUCL56354.

Figure 109: RAxML phylogenetic tree of the 20 closest ITS BLAST results

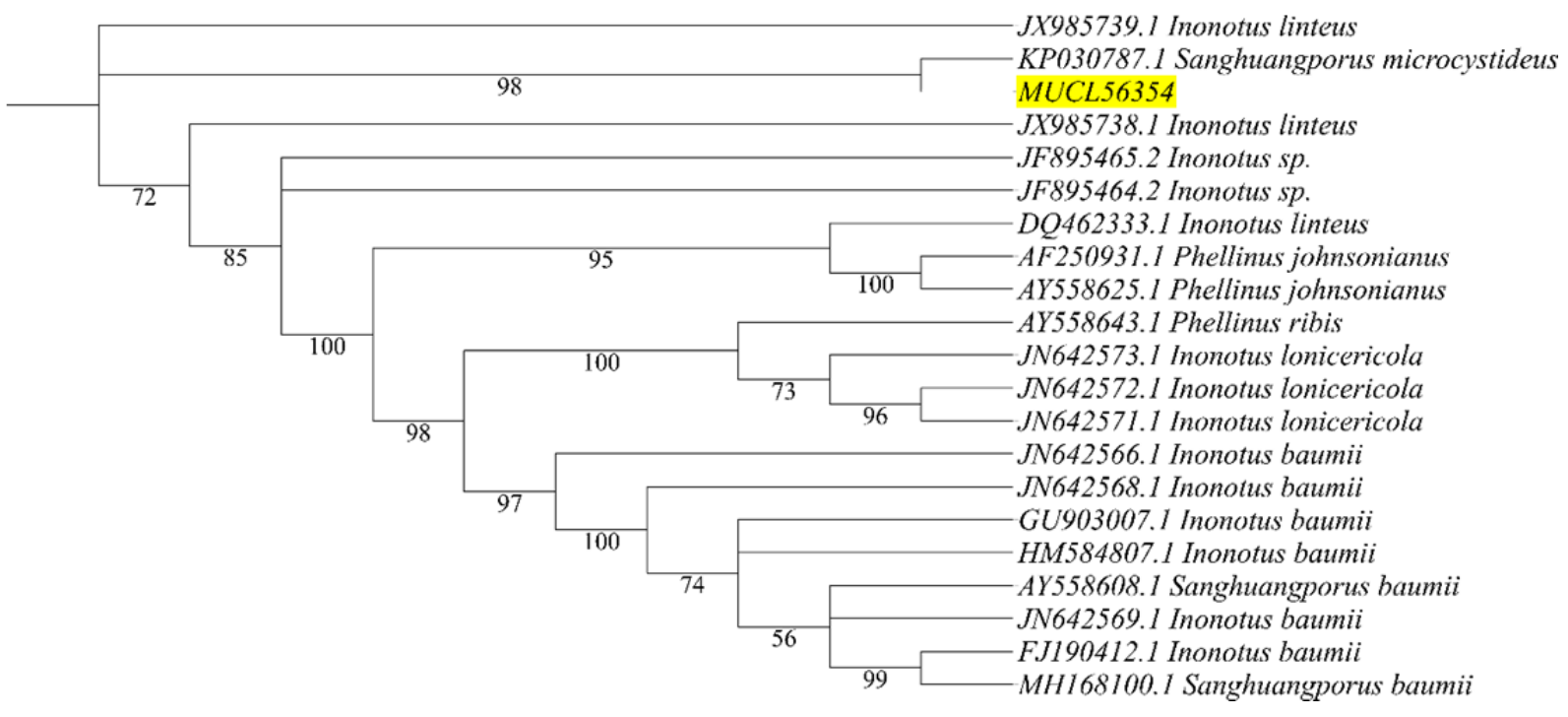




\section{Media}

YM 6.3: $10 \mathrm{~g} / \mathrm{L}$ malt extract, $4 \mathrm{~g} / \mathrm{L}$ yeast extract, $4 \mathrm{~g} / \mathrm{L}$ D-glucose and PH=6.3; Q6 1/2: $10 \mathrm{~g} / \mathrm{L}$ glycerol, $2.5 \mathrm{~g} / \mathrm{L}$ D-glucose, $5 \mathrm{~g} / \mathrm{L}$ cotton seed flour and $\mathrm{PH}=7.2 ; \mathrm{ZM}_{1 / 2}: 5 \mathrm{~g} / \mathrm{L}$ molasses, 5

$\mathrm{g} / \mathrm{L}$ oatmeal, $1.5 \mathrm{~g} / \mathrm{L}$ D-glucose, $4 \mathrm{~g} / \mathrm{L}$ sucrose, $4 \mathrm{~g} / \mathrm{L}$ mannitol, $0.5 \mathrm{~g} / \mathrm{L}$ edamine, ammonium sulphate $0.5 \mathrm{~g} / \mathrm{L}, 1.5 \mathrm{~g} / \mathrm{L}$ calcium carbonate and $\mathrm{PH}=7.2$ 